\title{
Proposed \\ AMENDMENTS TO THE COLUMBIA RIVER BASIN \\ FISH AND WILDLIFE PROGRAM (PHASE THREE) \\ 92-16
}

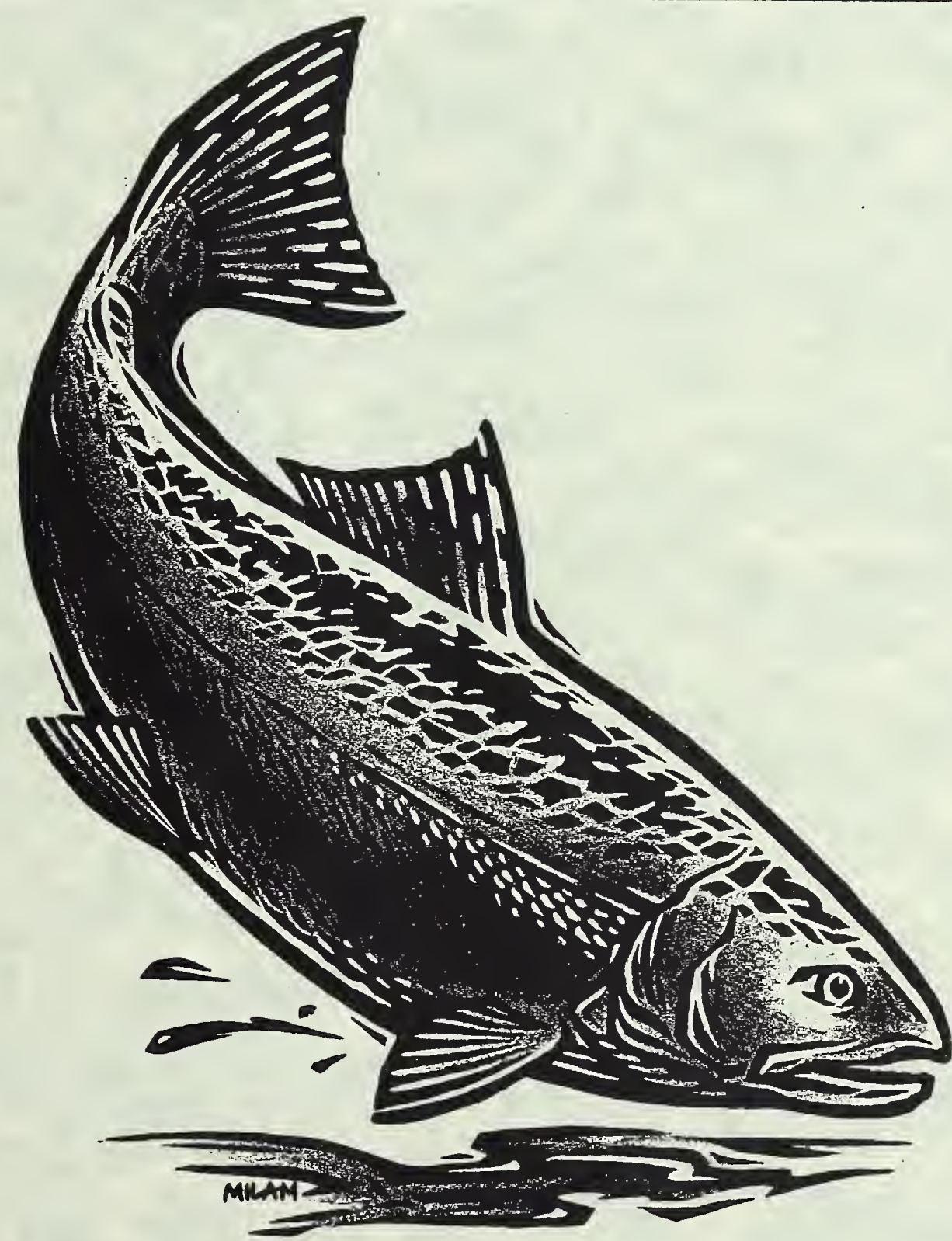

Northwest

Power Planning

Council

May 28, 1992 
Montana State Library

30864100311391 
TED HALLOCK

CHAIRMAN

Oregon

Angus Duncan

Oregon

James A. Goller Idaho

Robert (Bob) Sarvik Idaho
NORTHWEST POWER PLANNING COUNCIL

851 S.W. SIXTH AVENUE, SUTTE 1100

PORTLAND, OREGON 97204

Phone: 503-222-5161

Toll Free: 1-800-222-3355

FAX: 503-795-3370

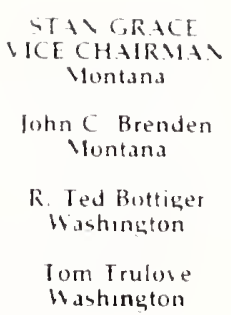

TIV GRACE
WCECHAIRMAI Vontans

n C Brenden

Ted Bottiger

om Trulose

May 28, 1992

Dear Interested Parties:

Thank you for requesting document $92-16$, the phase three draft amendment proposals to the Columbia River Basin Fish and Wildlife Program. Also enclosed is a companion publication, document 92-16A.

The Council currently is working on a revision of its Columbia River Basin Fish and Wildlife Program. Because of the urgency of some of the needed changes, the amendment process has been taking place in phases to allow some measures to be implemented while the region is considering others.

Phases one and two were completed in 1991. The Council is now in the third phase. Phase three expands the overall framework for the program that was begun in the first two phases. It provides further program goals, biological objectives and performance standards. It also includes more extensive monitoring and evaluation processes and looks at issues raised in the Integrated System Plan developed by the region's fishery managers.

Other areas that were deferred in the first two phases are addressed, such as fish production and habitat and passage in areas not previously covered. Together, the three phases, which will be complete in August, are designed to provide an integrated, systemwide plan to help naturally spawning salmon runs that have been designated as endangered or threatened by the National Marine Fisheries Service, as well as other depressed runs. A fourth and final phase to be developed later will deal with resident fish .. those that do not swim to the ocean .- and wildlife. Phase four also will integrate all phases into a new fish and wildlife program.

A working draft of proposed phase three amendments to the fish and wildlife program was circulated in May for early public involvement and review. Because the working draft was an informal document, not a rulemaking proposal, the Council did not request formal comment, but instead solicited any informal responses interested. 
- Much of the funding for salmon recovery has fallen on ratepayers through Bonneville Power Administration electricity sales. The Council has proposed broader sharing of this obligation. Given that the states and other entities are facing tight budgets and measures in the salmon plan necessitate additional work, is it reasonable to ask them to share in additional funding? Some entities already have assumed a larger share of the obligation. For example, the region's utilities have committed to funding the fishing license "lease-back" program to reduce harvest. The U.S. Forest Service and Bureau of Land Management have secured additional federal funds for habitat measures.

- The Council is proposing a goal to double the number of salmon and steelhead in the basin by 2015 with no further loss of biological diversity. The Council notes that efforts to increase fish production should avoid, to the maximum extent practicable, additional loss of biological diversity. Is this an appropriate goal?

- The Council has developed program goals, rebuilding schedules and performance standards for measures in the existing program and in this draft document. The Council also has completed new biological analyses on Snake River spring and summer chinook salmon (See Appendix E). Are all of these adequate? Or should additional goals, schedules and standards be developed? If the answer is yes, specific proposals should be made.

- The Council has proposed two alternative approaches to establishing habitat performance standards. Alternative $\mathrm{A}$ is a detailed list of specific standards, such as specific temperature limits for streams. Alternative B calls for maintaining existing standards and establishes a process for improving them. Which is the more appropriate approach?

- The Bonneville Power Administration has proposed criteria for selecting fish habitat projects (see Appendix A). There have been concerns about the level of complexity of these criteria. Is there a way to simplify them? Are the criteria appropriate given the Council's proposed habitat goals?

- Currently, there is debate on which fish should be treated as distinct population units. Some parties have urged that species be split into numerous populations, while others prefer to group fish populations together. For purposes of defining population management units. 
After comments have been considered, the Council may initiate additional consultations on the Phase Three proposed rule in late July or early August if it appears to the Council that further discussion of some of the issues would be useful. July 30 and 31 have been identified as tentative dates for the consultations. A decision about whether to hold the consultations and the issues to be covered in them will not be made until late July. Interested parties will be notified of the consultations by telephone. Please call the Council's central office at 1-800-222-3355 and leave your name and telephone number if you wish to receive notice of such consultations.

Thank you very much for your interest.

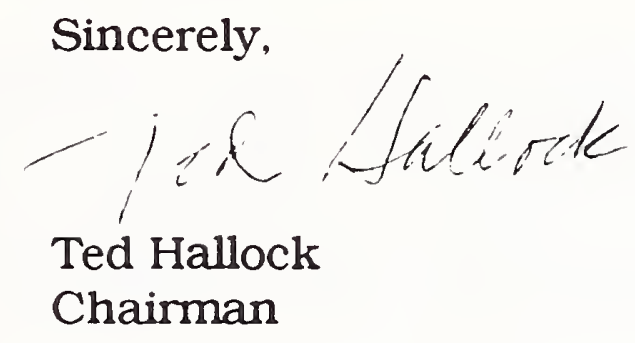

$\mathrm{p}: \backslash j \mathrm{jah} \backslash \mathrm{p} \&$ covlet.ltr 
. 


\section{PREFACE}

The attached draft combines all three phases of the Northwest Power Planning Council's current anadromous fish amendments to the 1987 Columbia River Basin Fish and Wildlife Program. Phases one and two were adopted in 1991. Proposed phase three amendments are presented here for public review. This is a draft document that is expected to change based on public input and completion of further analysis.

\section{Differentiating between old and new language}

While it makes for a longer document, the Council believes that seeing all three phases together will provide context and thus a more accurate view of the comprehensive salmon plan. To make it easier to follow, new language is presented in bold. Existing language (i.e. adopted in phases one and two) proposed for deletion is presented with strike-overs. Existing language with no changes is in ordinary text.

The adoption of phase three this year will mark the completion of the current amendments to the anadromous fish portion of the Council's program. The Council also will consider amendments to the resident fish and wildlife portions of the program on a schedule to be announced later this year as phase four. Phase four, scheduled for adoption in 1993, will integrate all amendments and the existing fish and willdife program into a new Columbia River Basin Fish and Wildlife Program.

\section{Comment on related documents}

The Council also is seeking comment on the proposed Integrated System Plan developed by the Columbia Basin Fish and Wildlife Authority. A summary of that plan is attached (see Appendix C). The chapter on supplementation, included as part of Appendix $C$, in the Integrated System Plan is new and was not in the draft originally available from the fishery managers. For the complete document, order Document \#91-16 from the address in the paragraph below. A summary of public comment and fishery managers' responses to comments also is available as Document \#91-17. In addition, the Council is seeking comment on the list of proposed supplementation experiments submitted by the Columbia River Inter-Tribal Fish Commission (see Appendix D). 
The Council believes that the region must act immediately to preserve and increase salmon and steelhead runs in the Columbia River Basin. The Council has divided its consideration of salmon and steelhead measures into three phases, so that key actions could be approved and implemented as soon as possible, even while other measures are still under consideration.

While the Council believes this approach makes practical sense and produces the best results for the fish, it does raise some procedural difficulties. For example, all three phases relate to the same subject, and the measures contained in each must work together. Accordingly, measures adopted in phases one and two need to be integrated with those measures in phase three, and some changes may be necessary to fit the measures together.

There is also a great deal yet to be learned about salmon and steelhead. New information continues to become available, and information received in the course of phase three may reveal better ways to achieve some of the objectives of phases one and two.

In addition, the Council's salmon and steelhead measures need to be coordinated closely with the endangered species proceedings before the National Marine Fisheries Service. As these proceedings move forward and recovery plans are developed, further revisions in the measures already adopted may be desirable.

Finally, the separation of these measures into phases creates a quandary for those who might consider petitioning for court review of the Council's actions. Under the Northwest Power Act, challenges to Council actions must be brought within 60 days of the date on which they become final. Although phase two is not intended by the Council as a complete answer to the basin's salmon and steelhead problems, parties who wait for the outcome of phase three before deciding whether to petition for review could be precluded from seeking review of phases one and two measures, even though those measures are intended to be part of a single, coordinated program. Two petitions for review of phase two are now pending, and the issues in both are likely to be affected by the outcome of the phase three rulemaking.

For all of these reasons, the Council has included measures from all three phases in the phase three document. As a convenience to the reader, the Council has highlighted new language in boldface type. However, the reader should understand that the entire document is the subject of this rulemaking and all parts, whether or not highlighted, are open for comment. 
Anyone who submitted comments on measures considered in phases one and two during the comment periods for those rulemalkings does not need to repeat those comments. The Council will deem all such comments to be resubmitted in phase three and will carry them forward into the phase three record.

Although the Council wants to offer the region the opportunity to view and comment on amendments in all three anadromous fish phases as an integrated document, the primary emphasis in phase three is on the measures that have not been considered in previous phases. Commentors are urged to focus on these new measures.

Measures adopted in the phase one and phase two rulemakings already have received intense and detailed comment from parties representing the full range of interests in the region. The Council carefully weighed and considered that comment in arriving at the phase one and two measures. Because these issues have received such close scrutiny, the Council does not expect that it will be necessary to revisit each phase one and two issue from the ground up in the phase three rulemaking. However, the Council recognizes that, for the reasons indicated above, there may be circumstances in which revisions to the earlier measures may be advisable.

The current versions of phase one and phase two will remain in effect until the phase three rulemaking concludes, which is expected in August, 1992. At that time, the final phase three rule will supersede the phase one and phase two final rules. This means that it will not be necessary for parties seeking court review of these measures to do so piecemeal. All of the phase three rule, including those measures incorporated from phases one and two, will be open for review at that time. 


\section{Digitized by the Internet Archive in 2016}

https://archive.org/details/proposedamendmen1992nort 


\section{CONTENTS}

Page

PREFACE

SCOPE AND EFFECT OF THIS RULEMAKING

Section A100: Introduction: The Columbia River, SAlmon and SteElhead, AND THE NORTHWEST POWER ACT

SECTION A200: PROGRAM FRAMEWORK AND COORDINATION

A201 COMPONENTS OF THE PROGRAM FRAMEWORK

A202: PROGRAM GOAL

A203: REBUILDING SCHEDULES AND BIOLOGICAL OBJECTIVES

(a) Snake River spring chinook

(b Snake River summer chinook

(c) Snake River fall chinook

(d) Other populations

A204: PERFORMANCE STANDARDS FOR PROGRAM FRAMEWORK

A205 COORDINATED IMPLEMENTATION, MONITORING AND EVALUATION

SECTION A300: MAINSTEM FLOWS, VELOCITY, AND TEMPERATURE IMPROVEMENTS

A301: PERFORMANCE STANDARDS

A302: RIVER OPERATIONS

A303: SNAKE RIVER MEASURES

(a) Spring migrants

(c) Fall chinook

A304: COLUMBIA RIVER MEASURES

(a) Spring migrants

(b) Summer migrants 
A305: SNAKE RIVER DRAWDOWN STRATEGY

A306: ADDITIONAL MEASURES TO INCREASE SURVIVAL

(a) John Day drawdown

(b) Additional storage

(c) Water measures

(d) River system operation investigations

(e) Flood control examinations

(f) Research and monitoring

Section A400: Mainstem screens, Predation, ANd Transportation

(a) Performance standards

(b) Measures

A402: PREDATION

(a) Performance standard

(b) Measures

A601 GOALS, OBJECTIVES AND REBUILDING SCHEDULES

(a) Management goals and escapement objectives

(b) Rebuilding schedules

(c) Consultation

A602 HARVEST RATES AND REGIMES

$\begin{array}{ll}\text { A603 STOCK IDENTIFICATION } & 90\end{array}$

A604 OTHER HARVEST MEASURES

(a) Review sport fishing regulations

(b) Accounting for incidental harvest of salmon

(c) Law enforcement and public education on impacts of illegal or wasteful fisheries. 
(d) Harvest alternatives $\quad 92$

(e) Voluntary commercial fishing permit buy-back program 92

(f) Inclusion of Idaho on Columbia River Compact 93

(g) Unified reporting of harvest data 93

$\begin{array}{lll}\text { SECTION A700: } & \text { HaBITAT } & 94\end{array}$

$\begin{array}{lll}\text { A701 GOALS, POLICIES AND PERFORMANCE OBJECTIVES } & 97\end{array}$

A702 HABITAT PROTECTION AND IMPROVEMENT ACTIONS 100

(a) Land management 100

(b) Water quality and quantity 104

(c) Water diversion screening 107

(d) Habitat project priorities, selection criteria and 110 expedited funding procedure.

A703 COMPREHENSIVE WATERSHED MANAGEMENT

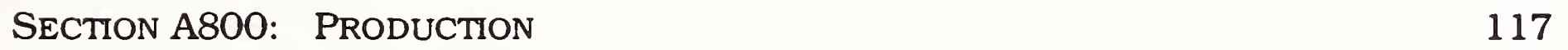

A801 GENETICS, NATURAL PRODUCTION AND SUPPLEMENTATION 118

(a) Genetics and natural production 118

(b) Supplementation coordination 122

$\begin{array}{lll}\text { A802 HATCHERIES } & 125\end{array}$

(a) Hatchery policies, coordination and operations 125

(b) Hatchery evaluation and assessment. 129

$\begin{array}{lll}\text { A803 PRODUCTION PLANNING } & 132\end{array}$

A804 OTHER PRODUCTION MEASURES 133

(a) Captive broodstocks 133

(b) Protecting endemic spring chinook in Minam and Wenaha 134

(c) Portable adult collection/holding and juvenile 134 acclimation/release facilities

(d) Ringold hatchery 135

(e) Supplementation of Snake Rive fall chinook 135

(f) Reintroduction of anadromous fish in the Upper Cowlitz 135

(g) Identify Pacific lamprey production opportunities 136

(h) Lower Columbia River coho 136

(i) Columbia River Chum Salmon 137 
(j) Columbia River Sea-Run Cutthroat Trout

(k) Sockeye

(l) Cryopreservation

(m) Evaluation of survival, ecology, carrying capacity and limiting factors

SECTION A900 INFORMATION MANAGEMENT

(a) Regional analytical methods coordination

(b) Research, monitoring and information dissemination

(c) Coordinated information system

(d) Project accounting data base

(e) Evaluation of new technologies

SECTION A1000 Mitigation of ADVERSE EFfECTS 


\section{INTRODUCTION: COLUMBIA RIVER, SALMON AND STEELHEAD AND THE NORTHWEST POWER ACT}

\section{(a) Overview}

Ever since the Northwest Power Act was passed in 1980, the Columbia River Basin's fish and wildlife have been the subject of increasing attention, not just from interest groups, but more and more from the public at large. A major goal of the Act is to address the impacts that the region's hydroelectric dams have had on fish and wildlife. During the past decade, significant efforts and money have been spent to protect and rebuild the affected populations.

But even that effort has not been enough for some species. Some of the region's salmon and steelhead runs have been dwindling at alarming rates, so alarming in fact that, for the past two years, certain populations have been the focus of regional, as well as national attention. It is a spotlight that many feel is long overdue.

The water that make up the huge Columbia basin have been the souree of a remarkable bounty for the Paeifie-Northwest. For eenturies, they have provided habitat and migratery routes for fish and witllife. In reent histery, they have also produech-eleetrieity and-provided water for irrigation, navigation, reereation, funieipalities andindustry.

But even the riehest resouree has limits, and water espeeially in the west is a finite resouree. Over the years, competing uses for Columbia-Basin water have begun to eonverge into what in some eases is a deadly eompetition, espeeially for eertin fish runs. This gro ring erisis has been evident for a number of years, and there have been signifieant-and, to some-degree, streessful-efforts to deat with it. But time has not been on the-side- of the-fish. The basin's salmon and steelheal runs that use the rivers for their spawing beds, rearing areas ant eorridors to and from the sea have been dwindling at-ataming rates for over a eentury.

The critical condition of these fish was graphically illustrated in 1991 , when only seven sockeye salmon were spotted making the 900 mile run inland from the Pacific Ocean to their spawning grounds in Idaho's Redfish Lake. 
Of the four known to havethat made it to the lake, only one was a female. In mid-November 1991, to no one's surprise, the National Marine Fisheries Service officially declared these Snake River sockeye salmon an endangered species.

In April 1992, the National Marine Fisheries Service designated Snake River spring/summer chinook and fall chinook as threatened species. Thesethe declarations triggered a set of actions required under the federal Endangered Species Act of 1973. One of these actions is be the development of a recovery plan. The Endangered Species Act sends a clear message that-the region does not have the option of taking no action.

Fortunately, the Northwest did not losehat time simply debating whether the sockeye and other runs summer and fall chinook-are in fact threatened or endangered. Building on its decade of experience in dealing with salmon, the Northwest began developing its own regional plan two year ago for those species that are in most critical decline. These include the wild and natural runs, particularly those that make the long journeys to and from the Snake River. The actions the region is undertaking are also expected to benefit overall salmon and steelhead populations as well. The National Marine Fisheries Service has begun using the

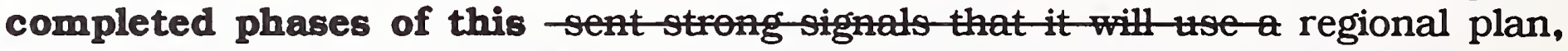
embodied in this document, as a basis for developing its own recovery plan.

Important groundwork for the regional plan was laid in athe Salmon Summit convened in late 1990 by the region's Governors and Senator Mark Hatfield. The summit, made up of the user, policy and interest groups connected with the Columbia Basin's waterways, came up with critical short-term measures that were implemented in 1991 to stem further decline. Those measures bought the region some time. From there, development of a regional salmon rebuilding plan moved to the arena of the Northwest Power Planning Council, the interstate body that has provided a regional forum for the past 10 years through its Columbia River Basin Fish and Wildlife Program. The Council, whose members are appointed by the Northwest Governors, was directed to develop its program under the Northwest Power Act.

The Council took up where the Salmon Summit left off in early 1991 by initiating a process to amend its fish and wildlife program in four phases. The first three phases ill-constitute a salmon rebuilding plan aimed, not only at rebuilding the three stocks proposed for listing under the Endangered Species Act, but also at aiding all weak salmon stocks. The fourth phase of the amendment process will address resident fish and wildlife and will integrate all amendments and the existing fish and wildlife program into a new Columbia River Basin Fish and Wildlife Program. 
This document (\#92-12) (91-31) includes amendments adopted as phases one and two plus amendments proposed of the salmon rebuilding plan. It eons a number of meastres that need to be implemented before the 1992 selmon migations. Together, phase one (available as doeument \#91 27) and phase three (seheduled to begin in late 1991) the three phases provide the region with a comprehensive rebuilding plan. This plan will not be static. The Council intends this plan to adapt as needed and as new information becomes available. Not only has the Council provided flexibility to make changes as appropriate, it has designed the plan to provide processes for adding to the region's knowledge.

Such a plan, developed with regional input, is an essential guide for the National Marine Fisheries Service. Without it, the federal government or courts would be left to impose a plan of their own. A regional plan, based on extensive input from all the basin's interest groups as well as Northwest citizens, has the advantage of reflecting the unique values, perspective and interests of the Northwest.

\title{
(b) The Northwest Power Act and the Fish and Wildlife
}

\section{ProgramMeastures and-Options}

The Northwest Power Act placed great emphasis on the fish and wildlife of the Northwest's Columbia River Basin. That emphasis is made clear in the language of the Act. For example, the Act states that one of its goals is:

\begin{abstract}
"to protect, mitigate and enhance the fish and wildlife, including related spawning grounds and habitat, of the Columbia River and its tributaries, particularly anadromous fish which are of significant importance to the social and economic well-being of the Pacific Northwest and the Nation and which are dependent on suitable environmental conditions substantially obtainable from the management and operation of the Federal Columbia River Power System and other power generating facilities on the Columbia River and its tributaries."
\end{abstract}

No single approach will bring about the changes needed to achieve this vision. Mainstem survival improvements, fish habitat and production measures, and harvest regulations all must work toward rebuilding healthy fish runs. Drawing a blueprint for these changes ultimately requires a judicious consideration of all the standards of the Northwest Power Act. Within this framework, however, several points deserve emphasis.

In developing the Columbia River Basin Fish and Wildlife program, the Council must, as much as possible, deal with the Columbia River and its 
tributaries as a system. This system touches a broad range of human activities--hydropower production, navigation, flood control, agriculture, and many other land and water development activities. Opportunities for improved coordination, cooperation, and conflict, are enormous. Building a fish and wildlife program that properly accounts for these activities requires the broadest possible involvement of the public and affected interests.

While the fish and willdlife program must "protect, mitigate and enhance fish and wildlife affected by the development, operation, and management" of Columbia River Basin hydropower facilities, it must do so in a way that assures the region "an adequate, efficient, economical, and reliable power supply." The Council has called for aggressive exploration of structural changes to the hydropower system, such as reservoir drawdown strategies, as well as nonstructural changes, such as innovations in system operations, seasonal exchanges, water use efficiencies, and the like. These nonstructural innovations in particular will require close integration among power system planning, fish and wildlife planning, and water use planning, to ensure that the needs of salmon, power and other users are addressed.

The region's fish and wildlife agencies and Indian tribes (known collectively in this program as the "fishery managers") play a special role in the program. When considering major amendments, the Council must begin by inviting the fishery managers to submit recommendations. The program must "complement" the agencies' and tribes" "existing and future activities," and also must be "consistent with the legal rights" of the tribes. When the Council receives conflicting recommendations for fish and wildlife measures, it must resolve inconsistencies "giving due weight to the recommendations, expertise, and legal rights and responsibilities" of these fishery managers. Under these provisions, the Council cannot "rubber stamp" the recommendations of the tribes and fish and wildlife agencies, but neither can the Council take on the role of a "super fish and wildlife agency."

In considering fish and wildlife recommendations, the Council must rely on the "best available scientific knowledge." This does not mean that the region can expect perfect knowledge before taking action. Action must be based on the best knowledge available at the time. Because that knowledge often is incomplete, the region must take pains to monitor actions and make adjustments where advisable. Monitoring and evaluation may be expensive, and results may be slow, but success over the long term may depend on the region's willingness to take these steps.

Where equally effective means of achieving the same sound biological objective exist, the Council chooses the alternative with the minimum economic cost. There should be little misunderstanding of this commonsense requirement: where a less costly way will achieve a given biological 
objective, the region should take it. However, Congress provided little room for cost comparisons where two alternatives would not achieve "the same sound biological objective." Instead, Congress indicated that economic considerations are subordinate to biological objectives in this section of the Northwest Power Act. Having said this, it is also clear that the Council must assure the region an adequate, efficient, economical and reliable power supply.

From a substantive perspective, improvements in mainstem survival must play a central role. The Northwest Power Act specifically recognizes that salmon depend on "suitable environmental conditions substantially obtainable from the management and operation" of power generating facilities of the Columbia River Basin. The Council is directed to adopt measures to "provide flows of sufficient quality and quantity between such facilities to improve production, migration, and survival of such fish as necessary to meet sound biological objectives."

Recognizing that federal implementing agencies must manage and operate hydropower facilities to provide "equitable treatment for fish and wildlife with the other purposes for which such system and facilities are managed and operated," it is appropriate that the Council's mainstem determinations aim to meet the needs of salmon with a level of certainty comparable to that accorded the other operational purposes. With these considerations in mind, the Council has adopted immediate mainstem survival measures; it has called for an ambitious series of additional steps to improve fish passage survival; and it is proposing biological objectives and rebuilding schedules that call for significant increases in mainstem survival rates over the long term. The Council regards these measures as a serious commitment that the region must make and keep.

\section{(c) Council Authority and Oversight}

The Council recognizes that its statutory authority is limited. Under Section 4(h) of the Northwest Power Act, the Council is given broad authority to develop fish and wildlife measures for implementation by Bonneville and other federal agencies. This authority is not comprehensive, and the Council has no defined statutory authority over actions within the jurisdiction of states or the Indian tribes. However, the Council believes that only through a comprehensive, regionwide approach will the salmon and steelhead stocks of the Columbia Basin achieve a successful recovery.

The Council has not attempted to distinguish between those measures where the Council believes it has direct authority and those measures where that 
authority belongs to others. Such distinctions may generate lucrative arguments among lawyers, but they will not help the fish.

These amendments, therefore, include measures that the Council believes are essential parts of a comprehensive plan, not merely those over which the Council has direct authority. In order to avoid disputes over authority, these amendments simply name those entities that need to take an action, and state the action. In those instances where the Council does not have authority to implement the actions called for, the measures should be considered advisory.

The fact that some measures are, in a technical sense, advisory does not mean that the Council intends them to be taken lightly or treated as optional actions. The region needs to act with a single will if it is to rebuild an important natural resource, the Northwest's salmon and steelhead runs.

The Council is calling on the parties identified as implementors of these measures to report to the Council every six months on whether they are meeting the performance standards and, if not, why not. For its part, the Council is committed to monitoring and evaluating implementation of this program much more aggressively than in the past. It will do so through audits, shared regionally and with the National Marine Fisheries Service, and through oversight activities associated with Council meetings. The Council will work aggressively to promote implementation of this program.

Many of the entities that will be responsible for implementing these provisions have already expressed support and willingness to proceed with implementation. Surmounting obstacles to implementation will be the primary responsibility of the implementing agencies. The Council offers its help, but it is not primarily a regulator or implementor. In the coming years, the Council will be much more an oversight agency, to ensure that problems in implementation receive the benefit of broad regional attention.

These amendments are intended to supplement the 1987 Columbia River Basin Fish and Wildlife Program except in those circumstances where the provisions of these amendments plainly supersede provisions of the 1987 program. Where the provisions of these amendments add additional measures, or subtract from or conflict with the provisions of the 1987 program, these amendments are intended to override the provisions of the 1987 program. With completion of phase four, the Council intends to have a new integrated and internally consistent Columbia River Basin Fish and Wildlife Program.

Ultimately, the successful recovery of salmon and steelhead stocks depends less on legal authority than on cooperation. Only through the committed and enthusiastic participation of all affected parties will a full recovery be achieved. 
To assist in this -work, the Couneil will-organize-and-eonvene-a Basin Oversight Group, eonsisting of state and feteral implementing entities and other interested parties, to oversee and-aggressively pursu implementation of this program. The Basin - Oversight Group will meet-on a regular basis and evatuate progress, problems and isstes regarding program implementation. The Fish Operations Exeeutive-Committee (deseribed in Seetion IH) will eorelinate with the Basin Oversight Group.

\section{(d) Historical Perspective}

\section{(1) Lessons of the Past Decade}

The Columbia River Basin Fish and Wildlife Program is not quite 10 years old, about the age of two generations of salmon. Unfortunately, the problems for the basin's fish have been more than a century in the making. If a decade has not been enough time to arrest the salmon's decline, it has been time to teach the region some important lessons. Any approach to fisheries recovery will require contributions from all who benefit from the river. And a rebuilding plan must be comprehensive. Piecemeal efforts simply have not been effective.

The challenge is best illustrated by the salmon's extensive environment, an environment created by migratory habits that recognize no governmental boundaries. Salmon are born in inland headwaters and travel downstream to mature in the ocean. Depending on the species, after three to five years, they return to the river. Thanks to an extraordinary homing instinct, they make their way to their home tributary where they will spawn and die. This wide-ranging environment--sometimes involving thousands of miles--became the arena for salmon recovery efforts in the 1980 s.

During that decade, for the first time the region looked at a coordinated approach involving the salmon's habitat; their passage down the rivers, particularly the mainstems of the Columbia and Snake; their harvest; and their production (both natural and artificially-aided). This approach echoes pleas to take an ecosystem approach to recovery under the Endangered Species Act, and it remains the foundation for a recovery plan in the 1990s.

While the foundation laid in the past decade for a systemwide approach was sound, the focus of the 1980 s proved too narrow. The fish and wildlife program's interim goal was to double runs, but not at the expense of genetic diversity. Overall runs ranged between about 1.5 and 4 million in the 1980s. However, some weaker runs continued to decline, thereby threatening genetic diversity and fitness. It became apparent that the diversity of the runs, not just the number of fish, was an important consideration. 
Despite some gains made in the early 1980s, overall salmon and steelhead populations are about a fifth of their predevelopment run size, and only about 20 percent of the remaining fish spawn in the rivers. (See Figure 1) Most naturally spawning stocks are declining, ${ }^{1}$ and some, such as the Snake River spring, summer and fall chinook and sockeye, have declined persistently to critical levels. (See Figures 2, 34 and 5)

\section{An Expanded Focus}

The endangered species petitions dramatically underscored the need to make preserving the diversity of the runs a higher priority. This renewed focus also affected the Council's own role. Previously, the Council's fish and wildlife program had addressed primarily the effects of the hydropower system on salmon and steelhead.

With the endangered species listings, it became clear that a realistic recovery effort had to be broader, involving all the river uses: power production, flood control, irrigation, navigation, water supply, recreation, land development practices and fishing. When the Northwest Governors, Congressional delegation and the National Marine Fisheries Service looked to the Council to come up with a comprehensive recovery plan, they also asked the Council to assume this broader role.

The Council has done so. It is in the process of developing an integrated plan that seeks contributions from all river users. The Council recognizes its authority is limited. In those areas where it has authority, this plan must be implemented by the appropriate agencies. In those areas where the Council lacks explicit authority, the plan is a strong recommendation. The Council urges implementation of even advisory measures on the grounds they make sense and could forestall more stringent measures that could be imposed from outside the region.

\section{Phased Recovery Effort}

The Council isbegan instituting a regional salmon rebuilding plan through amendments to its Columbia River Basin Fish and Wildlife Program in 1991. Existing measures in the program, as well as additional measures belowadded during the amendment process, be-are being integrated into an overall framework. Because of the size of the task and because some measures needed immediate implementation, the Council has broken down its effort into the following phases.

\footnotetext{
${ }^{1}$ There are some promising exceptions to the general decline in wild and naturally-spawning stocks. Some stocks, such as upriver bright fall chinook that spawn in the Hanford Reach of the Columbia, have increased during the last 10 years.
} 


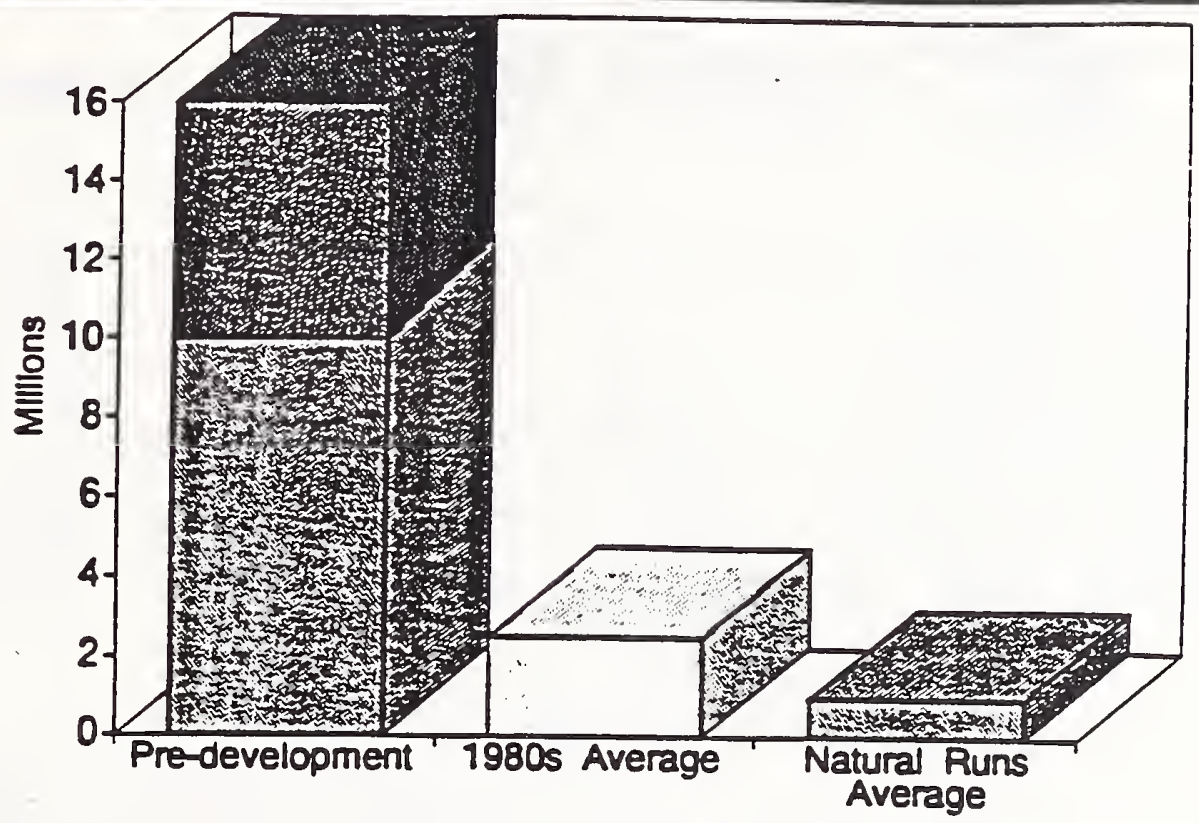

Figure 1

\section{SNAKE RIVER SPRING CHINOOK}

Figure 2

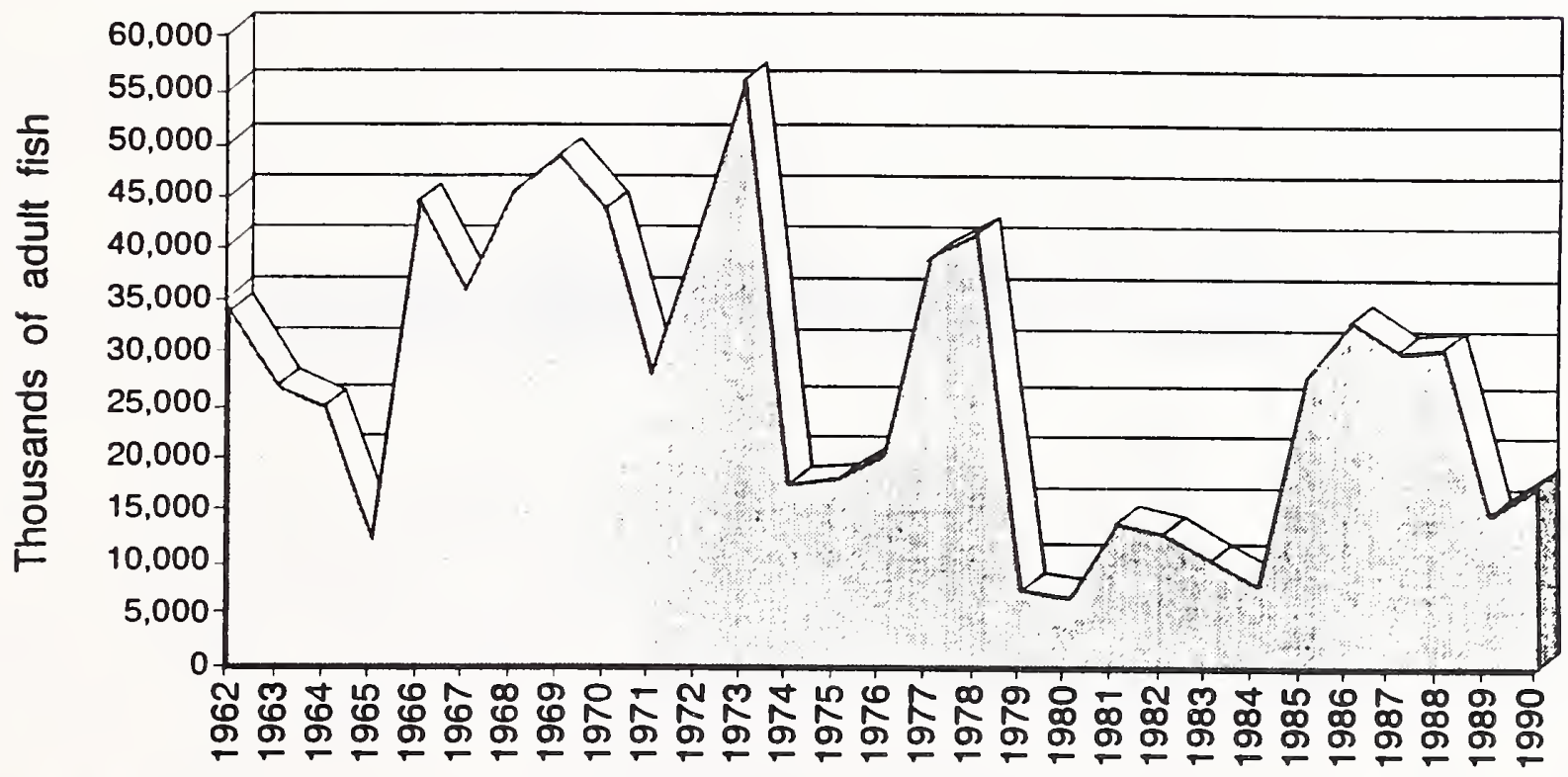

\section{CWN SNAKE RIVER SUMMER CHINOOK}

Figure 3

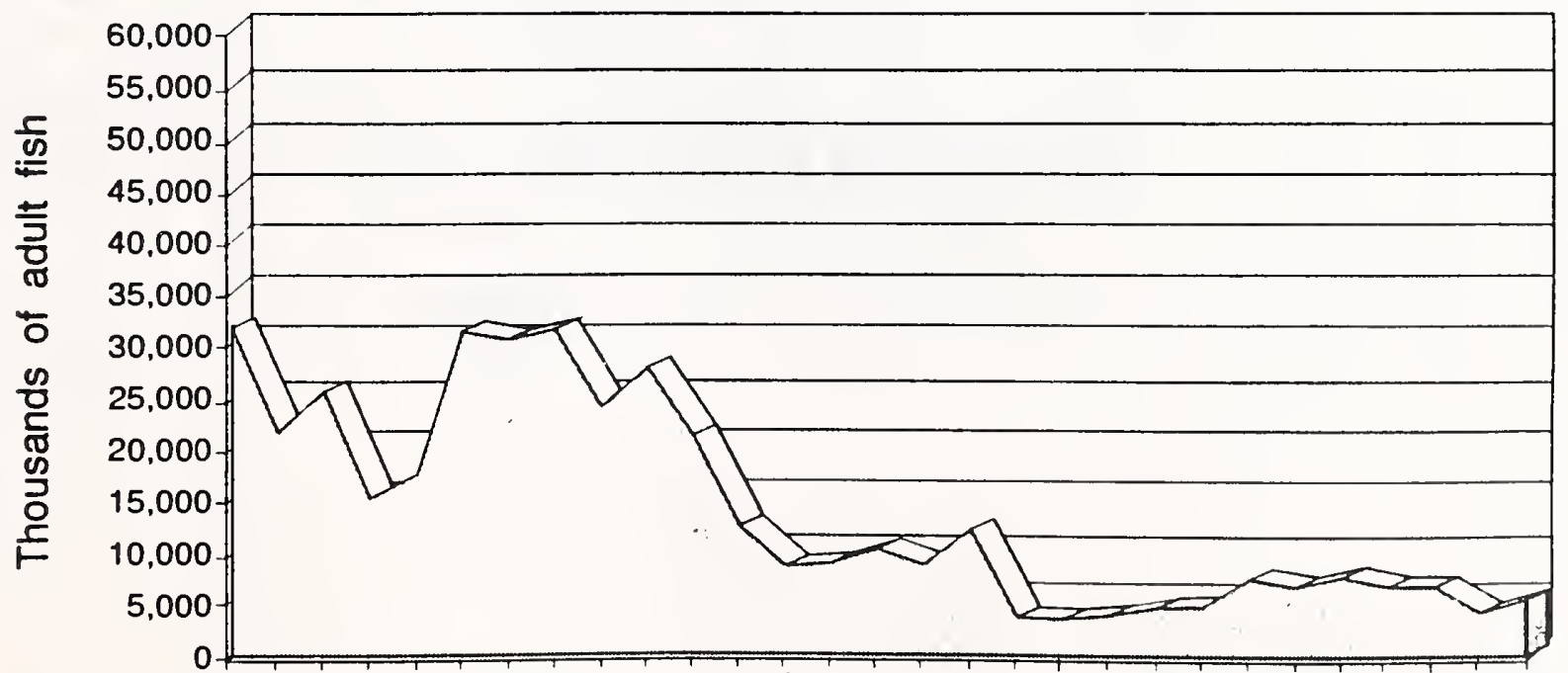

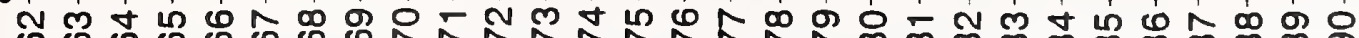

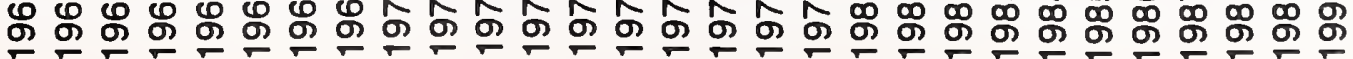




\section{SNAKE RIVER FALL CHINOOK}

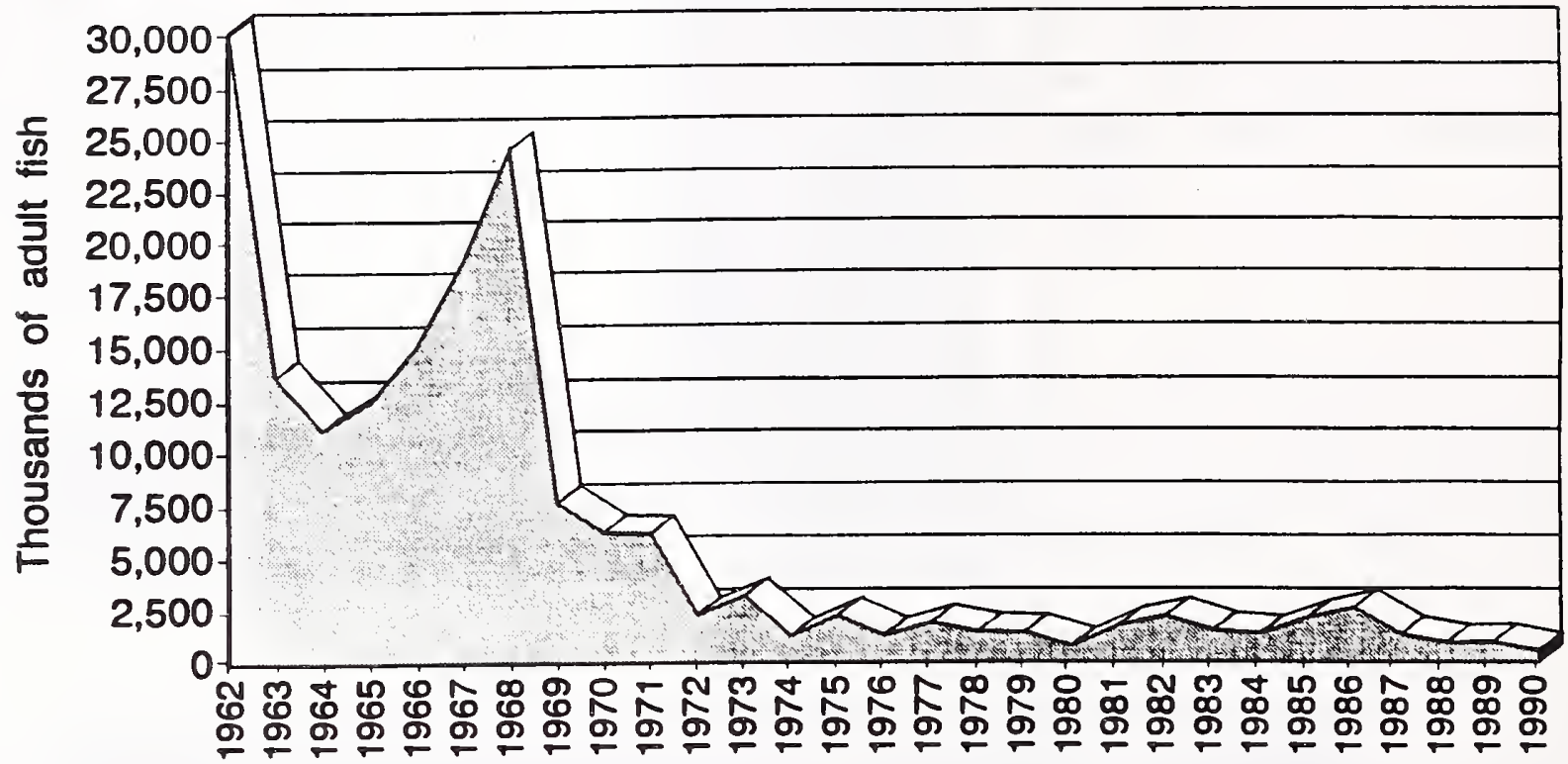

Figure 4

\section{SNAKE RIVER SOCKEYE}

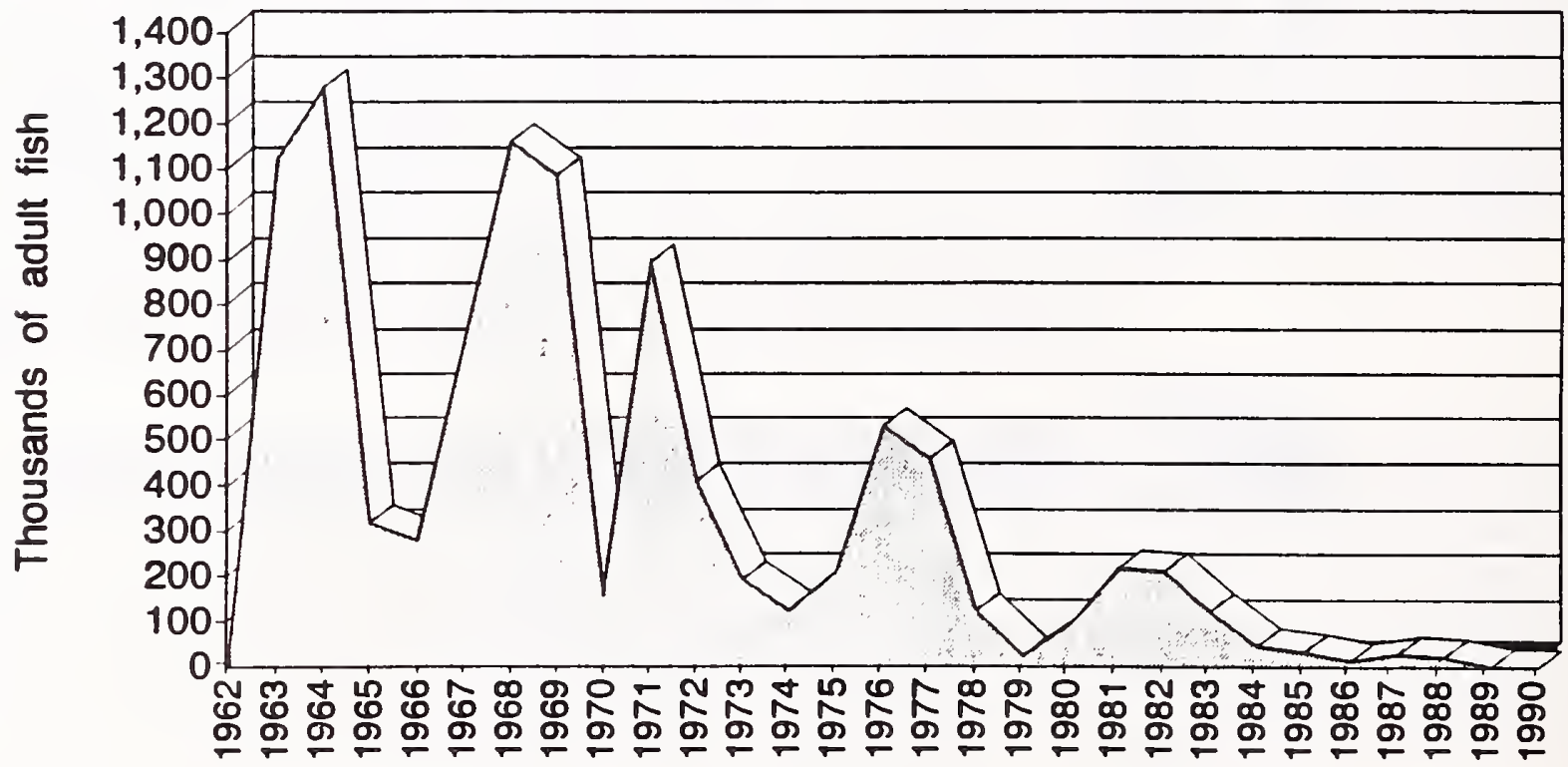

Figure 5 
Phase One: High Priority Production and Habitat Measures

In this phase one, completed in August 1991, the Council approved high priority measures aimed at improving production and habitat for weak salmon stocks. The Council selected measures to be funded in the current Bonneville budget that showed the greatest promise for aiding weak stocks in the short term. As a result, the region launched a large-scale program to screen water diversions, initiated measures to protect the genetic integrity of weak stocks, and endorsed an emergency captive broodstock program for the severely depleted Snake River sockeye. These measures have been or areaty being implemented.

Phase TWo: MAINSTEM SURVIVAL AND HARVEST

Beeause this doeumentembolies the work of phase two, it will be explained more fully below in the exeettre-sum Phase two began in latesumer of 1991 and was completed in December 1991. In this phase, the Council took two approaches. First, it identified mainstem survival, harvest, and some production and habitat measures that needed to be implemented for the 1992 salmon migration. Second, it committed the region to implement additional measures to further improve salmon and steelhead survival as soon as they are evaluated for feasibility, biological soundness and compliance with the Northwest Power Act. The Council also began developing a framework that will tie all the new and existing program measures together. Thertes

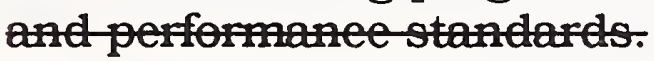

Phase THREe: System INTEGRATION

This phase begin in late-1991-shouldbegins formally with the publication of this document. It is expected to be completed by tate spaugust 1992. Phase three fleshes out an overall framework for the program that was begun in earlier phases. It provides program goals, biological objectives and performance standards. Phase three also emphasizes how the measures will be implemented, along with extensive monitoring and evaluation processes. In this phase, the Council is considering issues raised in connection with the Integrated System Plan developed by the Columbia Basin Fish and Wildlife Authority. This is a proposed plan that coordinates efforts to produce more salmon and steelhead in the nearly three dozen subbasins that produce these fish. The Council also considering broad issues of fish production and habitat policy, including the connection between recovery efforts for weak stocks and efforts to increase other stocks. This phase also addresses passage issues in such areas as the mid-Columbia and Willamette rivers. 
The framework started in phase two will be eompleted in phase three. It will inelude rebuitling sehedutes, biologiealobjeetives and performe standards. If neessary, partieutarly if new information emerges, the Couneil may revistareas addressed in the previous two phases.

PHASE FOUR: RESIDENT FISH AND WILDLIFE

The first three phases will constitute a regionally developed salmon and steelhead recovery plan. But the Columbia River Basin Fish and Wildlife Program is even broader. Congress directed it to protect and enhance all the fish and wildlife in the Columbia Basin that have been affected by hydropower. Phase four will take up issues related to resident fish (fish that do not migrate to the ocean) and wildlife. The Council has asked interested parties to submit recommendations for amending the resident fish and wildlife portions of the program by September 15, 1992. This phase, which will complete the overall updating of the fish and wildlife program, is expected to be final in 1993.

(The summary and analysis sections deleted below are Phase Two language that will be updated in a later version of these amendments.)

\section{A-Closer Look at Phase Two}

The-Couneil had three purposes in developing amendments for phase two. It was seeking to take major steps torard a long-term eomprehensive plan for reeovery of weat sedmon and steetheat runs that will.

1) Maintain the genetie resourees and biologieal diversity of the wild, naturally spaning and a tifieially propagated populations,

2) Preserve, wherev-possible, the number and eharater of reming rung; and

3) Inerease, over the long term, sustainable fish populations-suffieintly to provide an adequate havest for tribal, sport andeommereial fishers.

Phase two ealls for a wide varie of im ediate aetions, ineluding inereased flows in the Columbia and Snake rivers, fish passage improvements at fecleral hydroelectrie dams, measures-to improvesurval between dams, better jurenile fish transportation methods, predator eontrols andeontrols on harest.

Many of these aetions are direeted at the time it takes juvenile fish to travel to the oeen. Beeatre survival inereases as travel time deereases, redung travel time by inereasing flows is expeeted to inerease survival, partieularly lowater eonditions. A key immediate aetion ealls for storing more water behind dams in fall and winter and releasing it in spring during the eritieat juvenile salmon and 
steethend migrations. The inereased flow would help-speel the fish to the oeen and reduee their expostre to predators and disease. The phase wo amendments make it elear the Couneil is committel to substantinlly shortening spring selmon migration times through immediate-steps to improve-flows and water veloeity, improved bypass and transpertation, as well as other-measures designed-to aid froh migration. The Couneil has employed-all the feasible steps-it coutd identify to a hieve the existing water budget, plus substantially more water for flow regimes that aim to provide at least 85,000 eubie feet per seent and over 200,000 eubie feet per seeond in the Snake and Columbia rivers respeetively. These flows should inerease the survivat-of Snate-River spring and-summer ehinook and-soekeye setmon.

But even these steps, along with other measures adopted in phases one and two, do-not-appear to be enough to stem the deeline of ee tain stoeks. Flow atrgmentation is only one-wy to reduee travel time. Another way is lowering reservirs-so water flows faster and fish-spend less time in slaek reservir pools. The Couneil has ealled for a reservir draw plan for the lower Snake River and has set aggressive-sehedules for operations, design, mitigation and biologieat plans. The drawdow, along with water eonservation, new storage, innovative power operations and-other meastres-to improve-indrer migrations, will be implemented unless they are shown to be-structurally or eeonomieally infeasible, biologie lly unsound or inconsistent with the Northest Power Aet.

The Couneit also ineluded measures aimed at proteeting adult fish so that $a$ suffieient number ean return to spawn and rebuild salmon and steelheat populations. These ineluded eommereial and sport havest reduetions, new teehniques to enable-seleetive harvest and a program to reduee eommereial fishing in the short term. The Couneil is ealling for a reduetion in harvest of fall ehinoek to-55 pereent of the antul-run, dow from a high of 77 pereent in reent years, and a halt to the eommereial havest of soekeye below the eonfluenee of the Snake and-Columbia rivers. Only a limited treaty eremonial and subsistenee fishery should be permitted in order to protect any remaining adult Snake River soekeye. Measures were also alopted that provide for temporarily leasing eommereial fishing lieenses to futher enhanee the survival-of adult fish returning to their spaning beds. A measure also was ineluted to eontinu evaluation of eool water releases from behind Dworshat Dam to provide healthier water temperatures for adult fall ehinook.

\section{How Survival Will Be Affeeted}

If all of the-im diate-measures are implemented-on time-for the Snake River spring migration, they should leat to a slow and stealy rebuilding for several stoeks. For others, these measures may do little more than stabilize their populations. And, for a few stoeks, these aetions simply will not be enough-on 
their own. It is eertin that more-effort will be needed, and-it is also-ear that expanded efferts at ery stage of the salmon's life eyele are eritieat.

This is illustrated in the Couneil's modeling analysis for Snake River spring ehinook. In this analysis, the Couneil moleled improvements in the flow and weloeity, extended length sereens-at several mainstem dams and redued reservir mortality resulting from eontrol of predators. The analysis evaluated the effeets of these measures on naturally spawing spring hinool stoeks with low, moderate and high produetivity? This allowed the analysis to eover the range of habitat quatity and biologieal enarateristies for spring ehinook in differents parts of the Snatke River drainage.

The meastres should provide the largest benefit in the driest years when fish are at greatest risk. For sueh years, with all the measures in place improved flows, reservir drawdows, extended sereens, and a reduetion in reservir mortity the survivat rate for all juvenile-spring-hinook should-inerease-from just under 30 pereent to 39 pereent, and the rate for nontransported fish-should jump from 4 pereent to 22 pereent.

The importane of appropriate mainstem and havest improvements in rebuttling weats stoeks is obvious, and the Couneil has foetsecton these factors in phase two of this proeess. However, one of the insights that has emerged from andysis of these meastres is the role of good habitat and other eonditions that

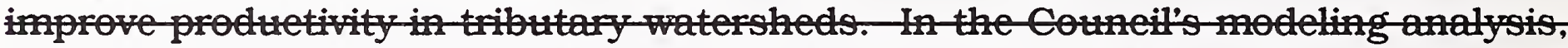
the more produetive-stoeks (which eome from subbasing with better habitat and envirenmentat conditions) inerease over the eoming deeades, with the meastres eon thed in the amendments (see Figure 5). On the other hand, less productive stoeks, whieh typieally eome from subbasing with degraded habitat, do not fare as well, (see Figure 6) and the least produetive stoeks trace a dark line toward extinetion (See-Figure 7). Thus, while mainstem and havest measures remain important, improved habitat for low produetity stoeks will be needed.

The situation for Snake-River fall-hinook-refleets the most une tain. Even when all measures in these amentments and the existing program are implemented, it will be diffieult to rebuild the fall-run. Strplementation,? additional meastres addressing habitat, and further evatuation of flows appear to be-ritieat. The Couneit has established a rebuilding sehedule-for this-severely depressed stok.

Anderen the more promising numbers for spring ehinook do not take-into aeeount the vagaries of nature. Beeatuse-some runs are-so preearious, another IH

2 Productivity refers to the health and-fertility of the fioh and the quality of their spawing hatat.

'Stpplementation. The release of hatehery fy juvenile-fish-in the naturatenvironment to quielty inerease-or establish naturally spaning fish poputations. 
Nine, stustained drought or other unpredietable events eould deal irreversible setbaeks. While the timing eannot be predieted, it would be naive not to expeet sueh an event. The more the runs ean be strengthened in the meantime, the more likely they will surve uneontrollable and random eatastrophes.

\section{(e) Costs and Responsibilities}

\section{(1) Two Types of Costs}

There are two types of costs associated with the fish and wildlife program-lost revenues and outlays. The additional storage to provide increased spring flows would mean that power operators would have to forego some power generation at the dams during winter months, reduce sales of power outside the region, and potentially make some additional power purchases. Some of the costs referred to in this draft document refer to projects, as well as flow measures, and these costs will be updated during this rulemaking.

The Council estimates the value of lost power production would average $\$ 70$ million annually. For the worst case scenario, in the lowest water years when the region would have to both euthest-purchase out-of-region energy to the fullest extent, the cost could be as high as $\$ 250$ \$170 million. These costs would be in addition to the approximately $\$ 55$ million in foregone revenues under the existing fish and wildlife program. In addition to lost revenues and purchases, the Council estimates direct costs of the measures adopted in phase two will be about $\$ 30$ million in 1992. These costs are added to approximately $\$ 90$ million in Bonneville outlays to fund the current program and to repay the U.S. Treasury for the costs of screens and fish ladders at the mainstem dams, as well as other fish mitigation obligations. These costs are expected to escalate as bypass screens are funded by Congress and added to the Bonneville debt, and as other program costs rise.

It is estimated that the impact of the total costs could translate into about a 4 percent increase in the Bonneville Power Administration's wholesale rates, which could increase as additional capital obligations are incurred. The impact on retail sales is expected to be somewhat less, and will ultimately depend on how utilities choose to pass on their costs and how much of their costs stem from hydropower generation.

These are substantial costs, but the region should also bear in mind the cost of inaction. Without effective restoration measures, the region stands to lose wild salmon stocks whose genetic resources may be critical to the long-term sustainability of the Snake River runs. Without an effective regional program, a federally-administered Endangered Species Act process could impose substantially 
more onerous costs on irrigators, electric utilities, navigators, fishing communities and others who use the Columbia River and its resources. While the Council has not sought to put a dollar value on this outcome, no one should mistake the value of a determined, long-term recovery program.

\section{(2) Regional Funding and Staffing-Gapabilities}

Because it is a regional program to rebuild weak salmon stocks, the Council's program calls for participation and funding by state and federal entities and others. As a result, many of these agencies have requested additional funding from the Bonneville Power Administration to comply with the Council's measures.

The Council is concerned by these requests and believes responsibility for implementing the measures in this program must be broadly shared if the region is to minimize economic impacts. All levels of government must bear responsibility for adequately funding and staffing salmon rebuilding measures or run the almost certain risk that the recovery effort will be delayed with potentially disastrous results. State governments, as well as the federal government, must recognize an interest in adequately funding implementation of these measures. At the request of the governors, the Council has developed a regional program that in some respects goes well beyond the Council's authorities, and the governors have pledged to implement this program.

To this point, the majority of salmon rebuilding costs has been borne by electric power consumers through the Bonneville Power Administration. To the extent that measures respond to the impacts on salmon by the region's hydroelectric system, these costs are appropriate. But salmon runs were diminished, and rebuilding measures are required, because of a variety of other causes. The costs of responding to these other causes should be shared by all responsible parties.

\section{Council Commitments}

The-eosts assoeiated with the progran-matre-it imperative that elear and measurable goals are set. As it gathered publie eomment on phase two, the Couneil-atso heard-a-great deat of support for the idea of establishing biologieally based objeetives to give overall-direetions to the salmen reeovery proeess. The Couneit-agrees, and has adopted a rebuilling sehedule and biologieat objeetives for Snake River fall ehinook, one-of the weakest stoeks. It intends to eomplete adoption of sehedules and-objectives for other stoeks in phase three.

The Council is committed to a stringent program of monitoring and evaluating progress to ensure that the region's investment pays off. Rebuilding 
schedules, biological objectives and performance standards are being instituted to provide explicit means of measuring progress. The Council will modify or eliminate activities that do not provide sufficient progress toward stated goals and objectives, and will consider other actions.

Several parties have raised concern about the effects that drafting upriver storage reservoirs for salmon flows could have on resident fish and wildlife in headwater areas. The Council does not intend to address the environmental problems of salmon by indiscriminately shifting environmental problems to upriver areas. The Council is committed to monitor, evaluate and avoid these impacts, and these impacts will be addressed further in phase four. These amendments are not intended to modify or supersede the provisions of section 903(b)(1) and (2) of the 1987 fish and wildlife program.

\section{Other comment received in public review of phases one and two of this} plan made it plain that the region is divided over the scientific merits of some major measures to rebuild fish populations. Two issues that remain intensely debated are the relationship of increased flows and fish survival and the proper role of supplementing natural fish populations with hatchery-reared fish. Both will be examined closely under the Council's program.

The Council also strongly believes that the region must work to improve its understanding of the interdependence among fish, wildlife, and human activities, such as power system operations, harvest, water use and land management. Relatively minor changes in any one of these can appear to have minor impacts on salmon, but taken together, they can have significant cumulative impacts.

The Council is obligated to base its decisions on the best available scientific knowledge. In some cases, even the best data is sketchy. The Northwest Power Act and the Endangered species Act processes make it clear that salmon stocks cannot wait for complete resolution of the debate. The Council has chosen to act, recognizing that the actions can be modified as new information is available.

\section{(4) Other Responsibilities}

The Council is an interstate compact whose members are appointed by the Governors of the Northwest states. It is not a federal agency. Its program is developed under the Northwest Power Act, not the National Environmental Policy Act or the Endangered Species Act. However, most of the program's specific measures are implemented by federal agencies.

To facilitate federal implementation, the Council explores environmental impacts of its proposals as fully as possible within its amendment process. Federal agencies are encouraged to make use of the Council's evaluation so that 
the region can act promptly to protect salmon and steelhead while complying fully with National Environmental Policy Act and Endangered Species Act requirements. The Council commits itself to working with the federal agencies to integrate the Council's processes with the National Environmental Policy Act and Endangered Species Act processes.

The Council recognizes that the decline of the salmon runs, particularly the Snake River fall chinook, poses special problems for Indian tribes to whom this nation has special responsibilities. The Council's program must be consistent with the rights of these tribes. The Council is committed to meeting its own responsibilities and to helping the federal agencies meet theirs, while addressing the problems of weak stocks.

\section{(f)}

\section{In Summary}

If the language of the 1990 s salmon rebuilding program is more subdued than the rhetoric of the 1980s, it is at least more clear-eyed. The region knows a lot more. It understands more. It has better tools and, despite continuing controversy, broader cooperation. The enormous scope of the recovery effort is clearer. It will take a lot longer and a lot more effort to rebuild a healthy and diverse salmon and steelhead population throughout the Columbia Basin. In fact, it will take a persistent effort into the next century to save some of the runs.

This is not a grim assessment. It is a realistic one. The amendments this are not a panacea, but a valuable foundation for the effort that is yet to be completed. At the same time, the region cannot lose sight of the fact that multipurpose development of the Columbia River system has produced huge benefits. These benefits need not be lost if all beneficiaries of the basin's waterways approach a rebuilding effort with a willingness to contribute. A regionwide cooperative effort is clearly preferable to federal or legal intervention that could lead to extensive and expensive conflict, litigation and economic disruption. Balance is a key word. The Council's overall intent is to have balance so that all uses of the river remain viable.

(Phase 1 introduction)

This is the first step in a three phase proeess to review and amend the Columbia River Basin Fish and Wildlife Program-

- The first phase is an expedited proess direeted at the highest priority needs for salmon and steelhead habitat and produetion, whieh produeed the amendments that follow.

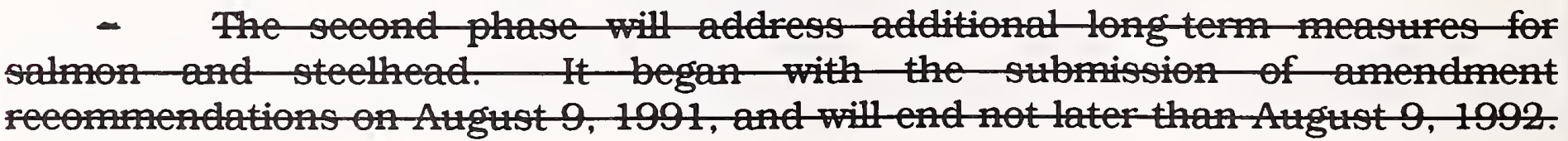


The Couneil intends to make- a deeision en seme- of these-amentinents, inetuting mainstem stunival, harvest, and other issues, in November of this year. After November, other satmon and steelhead issues, ineluding istues raised in the Integrated System Plan proposed by the-Coltumbia Basin Fish and-Willtife Authority, and other proposals, will be considered.

- The third phase, to begin with the submission of resident fish and willife reeo nendations in September 1992, willend by August, 1993.

This three phase proeess is prompted by severat faetors. First, the Northwest Power Aet requires the-Couneil to-open the program-to-amendment reeommentations at least every fre years, and the last general amendment proeess was in 1987. In adtition, the Couneil's revision of the power plan requires-a fish and willtife-program amendment proeess. Seeond, the system planning proeess the-Cotneil began in 1987 has prodtued proposed-sublbasin plans and a system plan, and the-Couneil had intended to rewiew the fish and willtife program in light of these plans in 1991-1992. Indeed, in the syster planning proeess, the-Couneit had-astred-the fishery managers and tribes to identify stoeks and areas of emphasis, to ineluche both a list of weak stoelss deserving priority attention, and opportunities for signifieant produrion inereases. Finally, the-Endangered Speeies Aet petitions, the-satmon sumit, ant the-governors' eharge to the-Couneil to develop a basinwide satmon-rebuilding program made-it-imperative to review the program's provisions for weak salmon and steelhead-stoelss.

Beeause-of these-faetors, the-Couneil coneluded that weak satmon and steelhead-stoeks should-reevive early attention in the amendment proeess. The long term trend for salmon and steelhead in the-Colmmia-River Basin has been one of deeline sinee shortly after the-arivat of non-Indians. Salmon and-steelhead have been severely affeeted by dams, habitat loss and degradation, harvest and production pratiees, water diversions, and other aetivities. Even in a state- of nature, of eourse, naturat fluetuations eaused salmon and-steelhead-numbers to vy dramatieally from year to year. Large-seate-enironmental-ehanges (e.gr., oeean eonditions) ean mask the eonsequenees (positive and negative) of human aetivities. Hower, without putting undue emphasis on low numbers of returning adults in the last two years, and reeognizing the need to evatuate program-sucess over the long term, the-Couneit eannot ignore eoneerns that some will and natural-stoeks are now so weak due to human-impaets that they may not be able to withstand natural fluetuations.

The first stage- of the proeess is intended to identify habitat and produltion meastres that should be initiated right awy, without the extensive-debate that will go into the remaining program amendments. The measures the-Couneil has approved in this proess are not intended to affeet the ongoing implementation of meastres that are already in the fish and willtife-program. Beeause-the-revised 
fish and witllife program may follow a different format than the eurent program, the measures listed below do not follow the numerieal format of the existing program.

The Couneil used the following eriteria to identify the highest-priority needs for salmon and-steelheal habitat production:

1. Is the proposed meastre not yet ineluded in the fish and wildife proga?

2. Can the proposal be ensidered without. fuller information, eonsidering it as part of a more comprehensive program, or a fuller debate than eoultoeeur in this proeeso? 3

3. Is the primary purpose of the proposal to benefit a weat salmon-or-steelhent stoek? Weak-stoelso dere definet for this purpose as?

- listedin the Integrated plan's list of stoeks of high or highest eoneer.

- listed in the Ameriean Fisheries Soeiety report as at high or moderate rist of extinetion,

- stoeks the National Marine Fisheries-Serviee (NMFS) has proposed-to list. 4

4. Could the proposal be implemented rapidly and provide shot tem benefits, i.e., to improve-strvival or proteet genetie resourees in 1991 or 1992 ? Or,

5. Would the proposal produe information eritieat to the formulation of reeovery aetions for weak stoelss?

The-Couneil-atso-eratuated the proposals to-determine-if the standards-of the Northest Power A werestisfed,, 5 or if an importan action would be foreelosectifaetion-were not taken right awy.

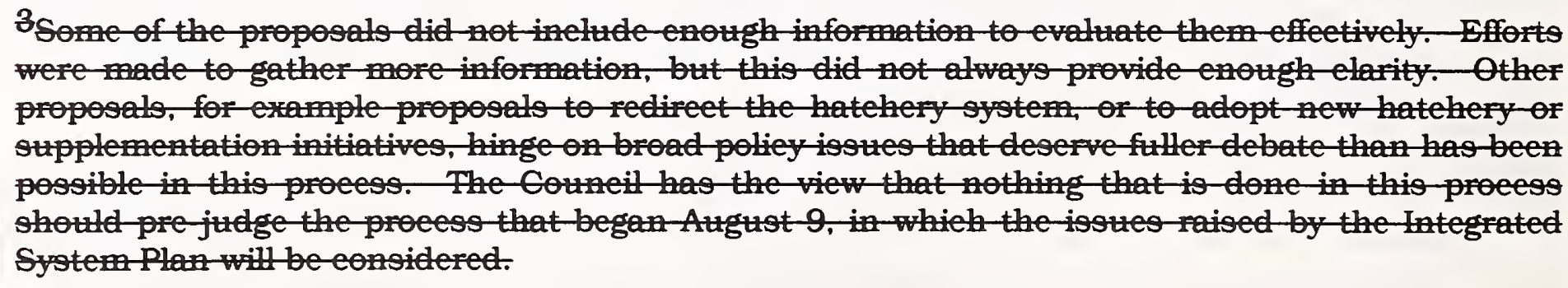
4The-Gouneil believes that foeusging only on Endangered-Speeies Aet stoeks would-eneourage more petitions, and negleet the opportunity to help other weak stoeks reeover. 
A number of proposals that emerged from the salmon summit, ineorporated in wo letters from the governors of the Northest states, were also-ensidered in this proess. These proposats appear generally to eomplement the Couneil's fish and witllife program. Those that related to the issues in this amendment proeess have-been-ineorporated-into the-program, and others will be addressed in the eomprehensive anendment proeess that begins August 9. The Couneil has initiated a proess to monitor the implementation of these aetivities. The Couneil applauds the eopperative effor that produed the aetivities outlined in the governors' letters, and eneourages the partipants to continu the effort and partieipate aetively in the Couneil's amentment proeedings.

The-Couneil is a ware that Bonnewille-is now or soon will be implementing some of the aetivities diseussed in the salmon sum and proposed in this proess. We eommen Bonneville-for being responsive to the need to adtress weat stoeks. Where the proposed aetivity has not yet been ineluted in the eurent Columbia Basin Fish and Wildlife Program, we expeet that Bonneville's interimplementan of the proposel will not supplant funds to implement other fish and willife program aetivities. We also-xpect that interim implementation will-not preelude full-reensideration-in the Couneil's amentment proess. The Couneil fully expeets that after the eomprehensive amendment proess has been eompleted, the program will-inelude all Coltumia-River Basin fish and willtife aetions that Bonneville is expeeted to fund.

The Couneil-emphasizes the need-for broal-eoperation in implementing these priority measures. Any eomprehensive program will require joint aetion, ineluding, in some eases, shared funding by ratepayers, the states, the feclerat governent, and-others. The Couneil has speeifieally ealled-for eost sharing in sevel of the priority measures. We believe that eost sharing opportunities should also be considered in eonneetion with other priority projeets, while not delaying rapid projeet implementation.

The Couneil intends to play an aetive role in promoting, monitoring and evaluating the implementation of these activities. We will facilitate-deeisions needed-to implement these measures, identify and seek removal of barriers to implementation, and provide a forum for exehanging information on the effectivens of implementation aetivities.

\footnotetext{
5 Measures must. (1) proteet, mitigate, and-enhanee fish and-wildife; (2) assure the region-an adequate, effieient, economieat, and reliable power-supply, (3) eomplement the aetivitieg-of the fish and willife ageneies and Indian tribes: (4) be based-on the bestatable-seientifie-knowledge:-(5) where there are equally effeetive ways to aehieve- a sound biologieat objective, the least eostly way must be enosen. (6) be consistent with the tribes' legal-rights, and (7) for andromous fish, improve ourvival at Golumbia River dams, or provide flows to improve their produetion, migration, and strvival.
} 
In what follows, the amendments themselves are set out. 


\section{SECTION A200}

\section{BEVELOPMENT OF A-PROGRAM FRAMEWORK AND COORDINATION}

To be effective, the fish and wildlife program must be more than a collection of measures. Otherwise, adding measures is like adding rooms to a house without a floor plan. Individual measures must be coordinated with each other and integrated into an overall plan designed to achieve specific goals and objectives.

The program framework provides the "floor plan" for the fish and wildlife program. It consists of an overall program goal, rebuilding schedules for identified population management units, biological objectives to achieve the schedules, performance standards to track change, and measures designed to meet the biological objectives. The framework thus provides a hierarchy of actions directed at achieving overall goals.

A key component is feedback, through implementation of actions and program monitoring, to facilitate the refinement of the program over time. To-nsure that this happens, the Couneil is developing an overall framework for the program. This effort began in phase two and will be completed in phase three. The framework is being organized around overall goals, biologient objectives, rebuilding sehedules and meastrable-performanee standards. The framework wilt provide a logieal basis for ineluling future-measures into the program. For this, the frameworkt will act as a yardstick for evaluating the performance of the

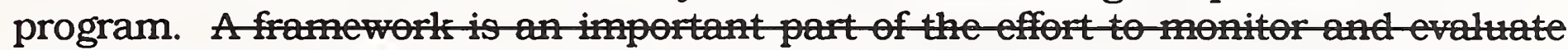
pereause there are many areas where current information is incomplete and because of the possibility of unforeseen events, the Council expects to revisit the biological objectives and performance standards as necessary based on information gathered by the monitoring program and through the evaluation of implemented actions. If progress toward the performance standards or meeting rebuilding schedules falls significantly short, the Council will revisit all or part of the program.

This seetion deseribes the framework ands a rebuilding sehedute and biologiealobjectives for Snake River fall-hinook. The sehedule and-objeetives will be reved in phase three of the amendment proess. Framework elements atso will be developed for Snake River spring and summer ehinook and soekeye during phase three of the amentment proess. Seetion VII deseribes tools and proesses to be used in de eloping the framework. 


\section{A201 Components of the Program Framework}

\section{(a) Program Goals}

The overall goals set the direction and scope of the program and provide the philosophy that guides the Council's selection of measures. Examples might include goals to maintain and enhance stock diversity, restore weak runs or double overall production. Collectively, the other elements of the program are expected to make significant progress toward or accomplish the overall goals.

\section{(b) Rebuilding Schedules}

Rebuilding schedules provide the management intent, numeric target for rebuilding and the expected time to achieve this

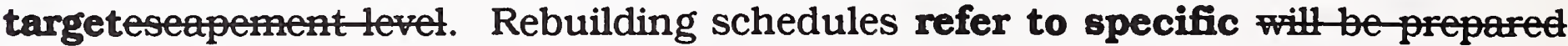
for population management units-and incorporate the idea of stock conservation units, minimum sustainable population size, compatibility with other stocks, and expected variability. Rebuilding schedules are bedll be based the biological needs of the fish, management goals, and the projected effectiveness of actions. Numeric rebuilding targets for population management units are planning targets that contribute to the Council's overall numeric goal. Like the overall goal, they are not intended to define or limit the obligation of any party under the Northwest Power Act. Rebuilding schedules and targets are dynamic elements that will likely change as knowledge increases and protection techniques are improved.

\section{(c) Biological Objectives}

Biological objectives state the amount of survival change needed in major program areas to meet the rebuilding schedule. While biological objectives may should incorporate policy concerns, they must be based on a sound technical and analytical foundation that incorporates all phases of the life cycle of salmon and steelhead. This will require development of analytical tools and information.

Biological objectives set targets for each stage in the salmon life cycle, including 1) juvenile passage survival, 2) adult passage survival, 3) critical habitat productivity, 4) harvest, and 5) depending upon genetic analyses, artificial production techniques to supplement rebuilding.

\section{(d) Performance Standards}

The effectiveness of actions is often uncertain and depends on other actions. It will be important for the Council and the region to track measures in a timely manner. Performance standards for each action or set of actions should provide an easily measurable index that relates to the type of biological or physical change intended. Performance standards provide a point of reference 
against which to monitor change, and units of measure to define change. TheyPerere not intended to state or limit obligations or to resolve technical uncertainties.

Performance standards will take a variety of forms. In some cases they will specify changes in survival when these are presently measurable; while in others, they may relate to physical or qualitative changes, or relate to accomplishing certain tasks within certain time frames.

\section{(e) MeasuresActions}

Program measures are specific actions to be undertaken and funded to contribute to achieving biological objectives and rebuilding schedules. When monitoring shows a program measure is not performing adequately, the measure should be modified or replaced. Measures must stand or fall on their demonstrated contribution toward the rebuilding schedule.

\section{A202 Program Goals}

In crafting the goal, the Council is faced with the challenge of balancing the need to increase the number of fish in the Columbia, maintain and enhance biological diversity, and preserve wild and naturally spawning populations.

The production of salmon and steellhead in the basin prior to development has been estimated at 10 to 16 million fish relative to a present total production of around 2.5 million fish. Five to 11 million fish are estimated to have been lost due to development of the hydroelectric system. Thus, significant change in the system is required. To address the loss due to hydroelectric development, the Council set a numeric target for the 1987 program of a doubling of the salmon and steelhead production in the Columbia basin.

While numeric increases are needed, they must be tempered with the notion that the Council wants increases that can be sustained over the long term. The importance of this was recognized by the Council in the 1987 program. Rebuilding was not to be driven inezorably toward a numeric goal, but was to be tempered by the assessment of genetic impacts, use of a mix of production methods, and priority on the area above Bonneville Dam.

Concern for biological diversity and preservation of wild stocks has been heightened by the recent petitioning of the several Snake River salmon populations for endangered or threatened status under the Endangered Species Act, and the identification of numerous other weak populations. There is increasing concern that preservation of the diversity of populations 
and biological traits present in the Columbia basin may be essential to maintain increased fish numbers on a sustained basis.

Unfortunately, these two resource values--increased numbers and biological diversity-often appear incompatible. On the one hand, measures to increase population size in the short term can decrease biological diversity. On the other, measures to conserve biological diversity may limit the region's ability to achieve short term gains in production. Sustainable increases in numbers, however, will require a healthy, biologically diverse resource that can be productive and accommodate environmental variability.

The Council sees its role to plan for the restoration of a healthy, productive resource throughout the accessible range of habitat in the Columbia basin. To do this on a sustained basis will require actions directed not only at increasing the number of fish, but also actions to conserve biological diversity and increase the productivity of natural stocks. Increased numbers and the conservation of biological diversity are not incompatible but are both key to the conservation of the resource and fulfillment of the obligations of the Northwest Power Act.

For this reason, the Council proposes as its overall goal the doubling of the total number of salmon and steelhead in the Columbia basin by 2015 with no further loss of biological diversity among or within anadromous and resident fish populations from conditions existing today. Efforts to increase fish numbers should avoid, to the maximum extent practicable, additional loss of biological diversity as a consequence of human intervention or inaction. A productive and biologically diverse population is essential to increased production that can be sustained over the long term. Because most of the loss of salmon and steelhead production as a result of hydroelectric development has occurred above Bonneville Dam, the Council will focus its efforts on this area. Except where human-induced habitat changes have produced increases in some species to the detriment of salmon and steelhead (squawfish as an example), efforts to meet these goals for salmon and steelhead should not occur at the expense of other native species and wildlife.

The Council recognizes that this goal will require actions on all fronts over many life cycles of salmon and steelhead. In the short term, it will require increased attention to the need to conserve biological diversity and halt the decline in many populations. This may occur at the expense of actions that might provide greater short-term increases in numbers but possibly jeopardize the biological health of the resource in the long term. It will require increases in mainstem passage survival, improved habitat and production practices, and diligent management of harvest. 
For purposes of the Council's goal, the following definitions apply:

Doubling is defined in terms of the adult equivalen $t^{2}$ population of salmon and steelhead at the mouth of the Columbia relative to the average population during the 1977-81 period--the five years prior to adoption of the first fish and wildlife program. The Council expects that achievement of the targets in the rebuilding schedules should result in at least this level of production by 2016.

Biological diversity means the array of genetic, physical, life history and behavioral characteristics contained within the salmon and steelhead resource of the Columbia basin. The Council recognizes that any action has the potential for causing some genetic change in the population. In establishing biodiversity as part of its goal, the Council states its desire to avoid adverse genetic change to the maximum extent practicable, to consider genetic impacts as important criteria for selection of measures, and to monitor changes in genetic and life history diversity as measures are implemented. This definition does not preclude carefully designed, controlled, and monitored supplementation programs.

\section{A2032 Rebuilding Schedules and Biological Objectives}

\section{(a) Snake River Spring Chinook}

\section{(1) Population Management Unit}

This population management unit is defined as naturally spawning spring chinook salmon originating above Lower Granite Dam on the Snake River. The Council recognizes that there may be a number of potentially distinct populations that are incorporated within this population management unit. If monitoring indicates that escapement needs for individual populations are not being met, the Council may modify its definition. Returns of fish to hatcheries above Lower Granite Dam are not included in this population management unit.

\section{(2) Characteristics}

These fish spawn mainly in tributaries to the Snake River. Juveniles rear for one year in the tributaries and migrate downstream as yearlings in the spring. Adults return after one to four years in the ocean in the spring and early summer. The assumed dates for passage of spring chinook at Lower

2 The adult equivalent population is defined as the number of fish that would have returned to the mouth of the Columbia River in the absence of any prior harvest. 
Granite Dam are March 1 through June 17. Idaho Department of Fish and Game has identified 14 populations within this population management unit.

\section{(3) Present Condition}

The return trend in fish in this population management unit is shown in the graph belows . Naturally spawning spring chinook above Lower Granite Dam declined sharply in 1979. Lower Granite Dam began operation in 1975 and reported its first fish counts in that year. The average return from 1975 until the drop in 1979 was 27,200 fish. Since 1979, returns have fluctuated around an average of 6,900 fish with a low of 2,400 fish in 1991 .

Lower Granite Adult Naturally Spawning Spring Chinook Returns

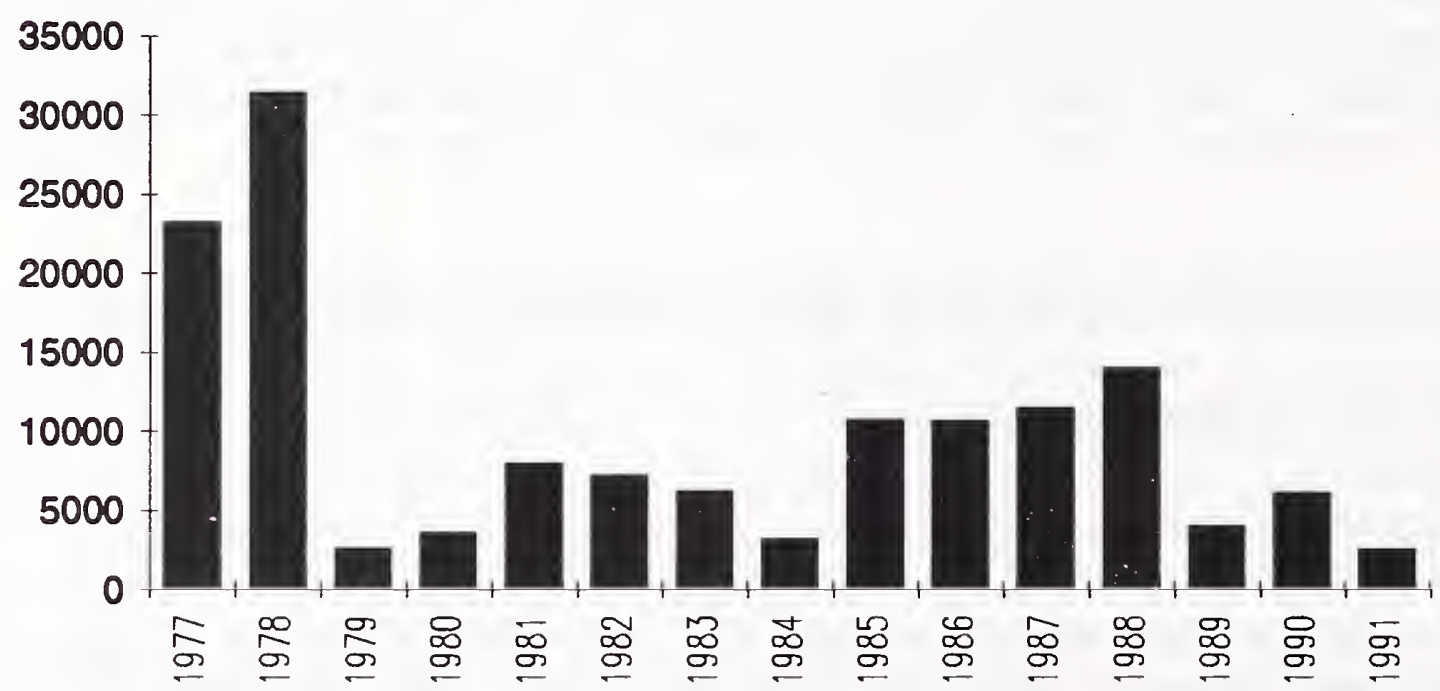

(4) Management Goal

The management goal at the level of the population management unit is to achieve productive and biologically diverse naturally spawning populations that can support stock specific tributary fisheries above Lower Granite Dam and be compatible with carefully regulated mixed stock fishing in the Columbia River. To do this, the population must also be compatible with mortality resulting from adult and juvenile passage through the mainstem after the region's best efforts to minimize these losses.

3 The count of fish at Lower Granite Dam has not been differentiated into natural and hatchery components prior to 1977. 
The rebuilding taarget for the Snake River spring chinook population management unit is an average of 40,000 adult fish at Lower Granite Dam destined to spawn under natural conditions. This would approximate the pre1979 level, and should allow limited tribal and non-tribal harvest. Natural variations in returns are a part of the target. The period since 1979 has been one of stability in regard to dam construction in the Snake River basin. During this period, the lowest return was about $35 \%$ of the mean while the highest was $202 \%$ of the mean. If this represents a reasonable range of natural variation, then we could expect the low after rebuilding to be about 14,000 fish, and the high to be about 80,000 fish.

This represents an ambitious goal. Relative to the estimated 1991 return of wild fish, it will require more than an order of magnitude increase in numbers. However, this level of production has been seen in the recent past. While some of the change after 1978 may be the result of conditions beyond human control such as ocean survival, it remains the task to reverse or mitigate for changes that have occurred in passage, habitat, and fish health.

Based on the management goal, the Council establishes the following rebuilding schedule for Snake River Spring chinook ${ }^{4}$ :

\begin{tabular}{|l|l|l|l|}
\hline & Low & Median & High \\
\hline Cycle 1 (1993-1996) & 7,700 & 13,900 & 23,700 \\
\hline Cycle 2 (1997-2000) & 10,000 & 18,000 & 30,700 \\
\hline Cycle 3 (2001-2004) & 11,600 & 21,500 & 36,100 \\
\hline Cycle 4 (2005-2008) & 14,400 & 25,900 & 44,000 \\
\hline Cycle 5 (2009-2012) & 17,800 & 31,700 & 51,700 \\
\hline Cycle 6 (2013-2016) & 20,000 & 35,000 & 56,400 \\
\hline Cycle 7 (2017-2020) & 22,000 & 38,000 & 60,400 \\
\hline Cycle 8 (2021-2024) & 22,800 & 40,000 & 61,600 \\
\hline
\end{tabular}

(6) Biological Objectives

To accomplish this rebuilding schedule, the Council believes that measures should be taken to make the following changes in survival rate at each life stage ${ }^{5}$ :

${ }^{4}$ Details of the rebuilding schedule including time frame and numeric targets will be projections based on information available at the time. Anaytical work necessary to do this is underway, but not yet completed.

5 Biological objectives will likewise be set by analytical projections of based on available knowledge. These will be included in later drafts. 
Needed improvement in survival rates

\begin{tabular}{|l|l|l|l|l|l|}
\hline & Egg-Smolt & $\begin{array}{l}\text { Juvenile } \\
\text { Passage }\end{array}$ & Harvest & $\begin{array}{l}\text { Adult } \\
\text { Passage 7 }\end{array}$ & $\begin{array}{l}\text { Pre- } \\
\text { Spawning }\end{array}$ \\
\hline Cycle 1 & $0.0 \%$ & $\mathbf{3 9 . 1 \%}$ & $\mathbf{0 . 0 \%}$ & $\mathbf{0 . 0 \%}$ & $\mathbf{0 . 0 \%}$ \\
\hline Cycle 2 & $\mathbf{0 . 0 \%}$ & $\mathbf{6 5 . 3 \%}$ & $\mathbf{0 . 0 \%}$ & $\mathbf{5 . 0 \%}$ & $\mathbf{0 . 0 \%}$ \\
\hline Cycle 3 & $\mathbf{1 2 . 5 \%}$ & $\mathbf{9 2 . 4 \%}$ & $\mathbf{0 . 0 \%}$ & $\mathbf{0 . 0 \%}$ & $\mathbf{0 . 0 \%}$ \\
\hline Cycle 4 & $\mathbf{2 5 . 0 \%}$ & $\mathbf{0 . 0 \%}$ & $\mathbf{0 . 0 \%}$ & $\mathbf{0 . 0 \%}$ & $\mathbf{6 . 3 \%}$ \\
\hline
\end{tabular}

\section{Rebuilding Strategies}

To achieve the rebuilding schedule will require aggressive action on several fronts. Snake River spring chinook populations are limited by mainstem passage survival, habitat loss, adverse interactions with hatchery fish and other factors. Rebuilding will require actions to address all of these factors. Measures included in the appropriate section of this program will address these issues. Subject to guidance from the National Marine Fisheries Service, carefully controlled supplementation of natural stocks will be used when necessarys.

\section{Performance Standards}

The Council will track progress toward the rebuilding schedule through the Lower Granite Dam counts corrected for the hatchery contribution. Considerable natural variation is expected. The Council will expect returns during each cycle to not fall below the low point in the rebuilding schedule table and provide the expected average over the time period. Returns below the projected low point for any cycle will trigger emergency Council review of its measures.

\section{(9) Population monitoring}

While the dam counts will provide important, timely information on progress, they integrate across several possibly diverse populations of spring chinook above Lower Granite. In so doing, important information about the status of these component populations can be lost. At the same time, it may be prohibitive, both in terms of money and effort, to closely monitor each and every potentially distinct population within this single population management unit. Monitoring also has the potential for causing mortality to

6 Eight lowest water years

7 Per project

8 Snake River spring, summer and fall chinook are listed as threatened under the Endangered Species Act. The role of hatchery production in the rehabilitation of these stocks will depend on the provisions of that Act. 
weak populations. For these reasons, the Council intends to establish a limited number of indicator populations that will be the focus of intensive monitoring. The genetic stock identification work in section A800 may refine these indicator stocks in the future. The purpose of indicator stock monitoring is to not only provide detailed stock status information on these particular populations, but to also provide basic life history and survival information that will be applicable to all populations within the population management unit. This will provide the Council with a clearer picture of the factors limiting natural populations within the population management wnit and permit refinement of the program over time.

To do this, the Council calls on the implementing agencies and the fishery agencies and tribes to propose a set of not less than three and not more than seven populations that can serve as indicators of the Snake River spring chinook population management unit. These can include hatchery stocks if necessary to provide harvest rates, for example. The indicator stocks selection should be closely coordinated with and take advantage of existing monitoring and research efforts including the US/Canada treaty. Idaho habitat evaluation, and Idaho supplementation research. The parties should work closely with Idaho Fish and Game and the Nez Perce and Shoshone-Bannock tribes to prepare a proposal. The proposal should include not only a list of populations but also the appropriate information to be collected for each population. This should include basic life history and survival rates as well as stock status. The proposal should be submitted to the Council by December 31, 1992 for implementation in 1993.

\section{(b) Snake River Summer Chinook}

\section{(1) Population Management Unit}

This population management unit is defined as naturally spawning summer chinook salmon originating in areas above Lower Granite Dam on the Snake River. The Council recognizes that there may be a number of potentially distinct populations that are incorporated within this population management unit. If monitoring indicates that escapement needs for individual populations are not being met, the Council may modify its definition. Returns of summer chinook to hatcheries above Lower Granite Dam are not included in the population management unit.

\section{Characteristics}

These fish spawn mainly in tributaries to the Snake River. Juveniles rear for one year in the tributaries and migrate downstream as yearlings in the spring. Adults return after one to four years in the ocean. The assumed dates for passage of summer chinook at Lower Granite Dam are June 18 to 
August 17. Idaho Department of Fish and Game has identified 6 populations within this population management unit.

\section{(3) Present Condition}

The return trend in fish in this population management unit is shown in the graph below . Naturally spawning summer chinook above Lower Granite Dam declined sharply in 1973 and again in 1979. Lower Granite Dam was completed and began counting returns in 1975 . The average return from this date until the drop in 1979 was 8,500 fish. Since 1979 , returns have fluctuated around an average of 3,100 fish with a low of 2,200 fish in 1988 .

Lower Granite Adult Naturally Spawning Summer Chinook Returns

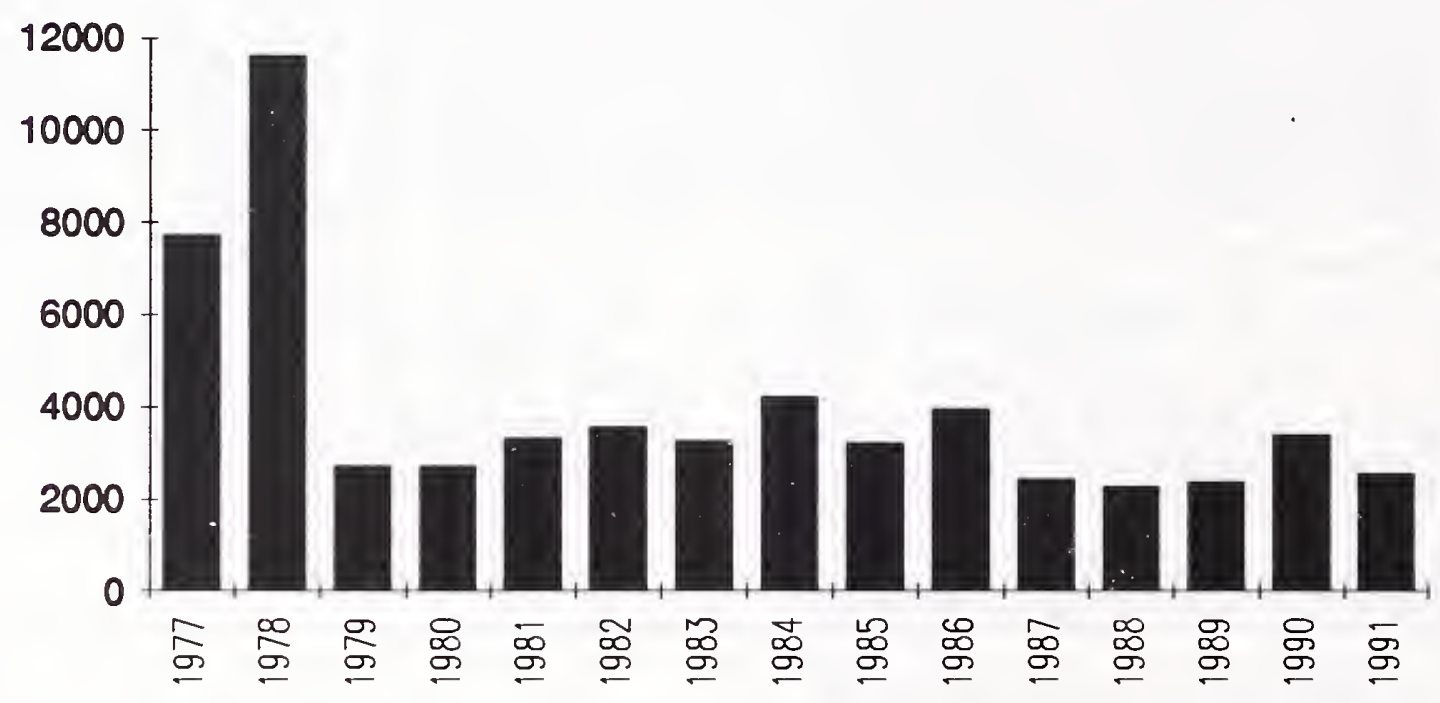

(4) Management Goal

The management goal at the level of the population management unit is to achieve productive and biologically diverse naturally spawning populations that can support stock specific tributary fisheries above Lower Granite Dam and be compatible with carefully regulated mixed stock fishing in the Columbia River. To do this, the population must also be compatible with mortality resulting from adult and juvenile passage through the mainstem after the region's best efforts to minimize these losses.

- The count of summer chinook at Lower Granite Dam has not been differentiated into natural and hatchery components prior to 1980 . Counts in the graph for 1977-79 contain a small number of hatchery fish. 
The rebuilding target for the Snake River summer chinook population management unit is an average of 15,000 adult fish at Lower Granite Dam destined to spawn under natural conditions. Natural variations in returns are a part of the target. The period since 1979 has been one of stability in regard to dam construction in the Snake River basin. During this period, the lowest return was about $73 \%$ of the mean while the highest was $135 \%$ of the mean. If this represents a reasonable range of natural variation, then we could expect the $10 \mathrm{w}$ after rebuilding to be about 11,000 fish, and the high to be about 20,000 fish.

This represents an ambitious goal. Relative to the estimated 1991 return of natural spawning fish, it would require more than doubling the population. However, this is a level of production that has been seen in the recent past. While some of the change after 1978 may be the result of conditions beyond human control such as ocean survival, it remains the task to reverse or mitigate for changes that have occurred in passage, habitat, and fish health.

Based on the management goal, the Council establishes the following rebuilding schedule for Snake River natural summer chinook ${ }^{10}$ :

\begin{tabular}{|l|l|l|l|}
\hline & Low & Median & High \\
\hline Cycle 1 (1993-1996) & 4,800 & 6,000 & 7,700 \\
\hline Cycle 2 (1997-2000) & 6,000 & 8,000 & 9,700 \\
\hline Cycle 3 (2001-2004) & 7,000 & 9,300 & 11,300 \\
\hline Cycle 4 (2005-2008) & 8,400 & 10,900 & 13,000 \\
\hline Cycle 5 (2009-2012) & 10,100 & 12,800 & 15,100 \\
\hline Cycle 6 (2013-2016) & 11,100 & 13,800 & 16,300 \\
\hline Cycle 7 (2017-2020) & 11,200 & 14,300 & 16,800 \\
\hline Cycle 8 (2021-2024) & 11,500 & 14,700 & 17,100 \\
\hline
\end{tabular}

\section{Biological Objectives}

To meet this rebuilding schedule, the Council believes that measures should be taken to make the following changes in survival rate at each life stage11:

10 Details of the rebuilding schedule including time frame and numeric targets will be projections based on information available at the time. Anaytical work necessary to do this is underway, but not yet completed.

11 Biological objectives will likewise be set by analytical projections of based on available knowledge. These will be included in later drafts. 
Needed improvement in survival rates

\begin{tabular}{|l|l|l|l|l|l|}
\hline & Egg-Smolt & $\begin{array}{l}\text { Juvenile } \\
\text { Passage 12 }\end{array}$ & Harvest & $\begin{array}{l}\text { Adult } \\
\text { Passage 13 }\end{array}$ & $\begin{array}{l}\text { Pre- } \\
\text { Spawning }\end{array}$ \\
\hline Cycle 1 & $\mathbf{0 . 0 \%}$ & $\mathbf{3 9 . 1 \%}$ & $\mathbf{0 . 0 \%}$ & $\mathbf{0 . 0 \%}$ & $\mathbf{0 . 0 \%}$ \\
\hline Cycle 2 & $\mathbf{0 . 0 \%}$ & $\mathbf{6 5 . 3 \%}$ & $\mathbf{0 . 0 \%}$ & $\mathbf{6 . 0 \%}$ & $\mathbf{0 . 0 \%}$ \\
\hline Cycle 3 & $\mathbf{1 2 . 5 \%}$ & $\mathbf{9 2 . 4 \%}$ & $\mathbf{0 . 0 \%}$ & $\mathbf{0 . 0 \%}$ & $\mathbf{0 . 0 \%}$ \\
\hline Cycle 4 & $\mathbf{2 5 . 0 \%}$ & $\mathbf{0 . 0 \%}$ & $\mathbf{0 . 0 \%}$ & $\mathbf{0 . 0 \%}$ & $\mathbf{6 . 3 \%}$ \\
\hline
\end{tabular}

(7) Rebuilding Strategies

To achieve the rebuilding schedule will require aggressive action on several fronts. Snake River summer chinook populations are limited by mainstem passage survival, habitat degredation, adverse interactions with hatchery fish and other factors. Rebuilding will require actions to address all of these factors. Measures included in the appropriate section of this program will seek to minimize mainstem passage mortalities, improve habitat where needed, and minimize adverse interactions with hatchery populations. Subject to guidance from the National Marine Fisheries Service, carefully controlled supplementation of natural stocks will be used when necessary ${ }^{14}$.

\section{Performance Standards}

The Council will track progress toward the rebuilding schedule through the Lower Granite Dam counts corrected for the hatchery contribution. The Council will expect returns during each cycle to not fall below the low point in the rebuilding schedule table and provide the expected average over the time period. Returns below the projected low point for any cycle will trigger emergency Council review of its measures.

\section{(9) Population Monitoring}

While the dam counts will provide important, timely information on progress, they integrate several possibly diverse populations of summer chinook above Lower Granite. In so doing, important information about the status of these component populations can be lost. At the same time, it may

\section{Eight lowest water years}

13 Per project

14 Snake River spring, summer and fall chinook are listed as threatened under the Endangered Species Act. The role of hatchery production in the rehabilitation of these stocks will depend on the provisions of that Act. 
be prohibitive, both in terms of money and effort, to closely monitor each and every potentially distinct population within this single population management unit. Monitoring activites also have the potential for causing mortality to weak populations. For these reasons, the Council intends to establish a limited number of indicator populations that will be the focus of intensive monitoring. The genetic stock identification project in section A800 may indicate that revision of these indicator populations is needed in the future. The purpose of the indicator population monitoring is to not only to provide detailed stock status information on these particular populations, but also to provide basic life history and survival information that will be applicable to all populations within the population management unit. This will provide the Council with a clearer picture of the factors limiting natural populations within the population management unit and permit refinement of the program over time.

To do this, the Council calls on the implementing agencies and the fishery agencies and tribes to propose a set of not less than three and not more than five populations that can serve as indicators of the Snake River summer chinook population management unit. These populations can include hatchery stocks if necessary to provide harvest rates, for example. The indicator stocks selection should be closely coordinated with and take advantage of existing monitoring and research efforts including US/Canada treaty, Idaho habitat evaluation, and Idaho supplementation research. The entities should work closely with Idaho Fish and Game and the Nez Perce and Shoshone-Bannock tribes to prepare a proposal. The proposal should include not only a list of populations but also the appropriate information to be collected for each population. This should include basic life history and survival rates as well as stock status. The proposal should be submitted to the Council by December 31, 1992 for implementation in 1993.

\section{(c) Snake River Fall Chinook}

\section{(1) Population Management Unit}

This population management unit is defined as naturally spawning fall chinook salmon originating in areas above Ice Harbor Dam on the Snake River. The Council recognizes that there may be a number of potentially distinct populations that are incorporated within this population management unit. If monitoring indicates that escapement needs for individual populations within the population management wnit are not being met, the Council may modify this definition of a population management unit. 
These fish spawn mainly in the mainstem of the Snake River above Lower Granite Dam and the lower sections of the major tributaries between Lower Granite and Hells Canyon dams. An unknown, but probably small, number of fish spawn in the mainstem between Ice Harbor and Lower Granite dams. Juveniles rear in the mainstem and tributaries and typically migrate downstream during their first summer. Adults return after one to four years in the ocean. The assumed dates for passage of fall chinook at Lower Granite Dam are August 18 to December 15. Population structure within this population management unit has not been determined.

\section{Present Condition}

The return trend in fish in this population management unit is shown in the graph below. Fall chinook above Lower Granite Dam have declined markedly since the completion of Hells Canyon Dam in 1967. This dam cut off access to up to 90 percent of the fall chinook habitat in the Snake River basin. Since 1975, when counting began at Lower Granite Dam, counts of fall chinook have averaged 666 fish. The low during the period was 340 fish in 1981, while the high of 1,000 fish was in 1975. Because the count over Lower Granite has been found to include a number of strays from Lyons Ferry Hatchery and elsewhere, the dam counts paint an unrealistically optimistic picture of the status of Snake River fall chinook. For example, in 1991, only 78 adult fall chinook at Lower Granite out of a total count of 382 could not be accounted for as strays from other areas. In 1992, this increased to 318 out of a total count of 630 .

Lower Granite Adult Naturally Spawning Fall Chinook Returns

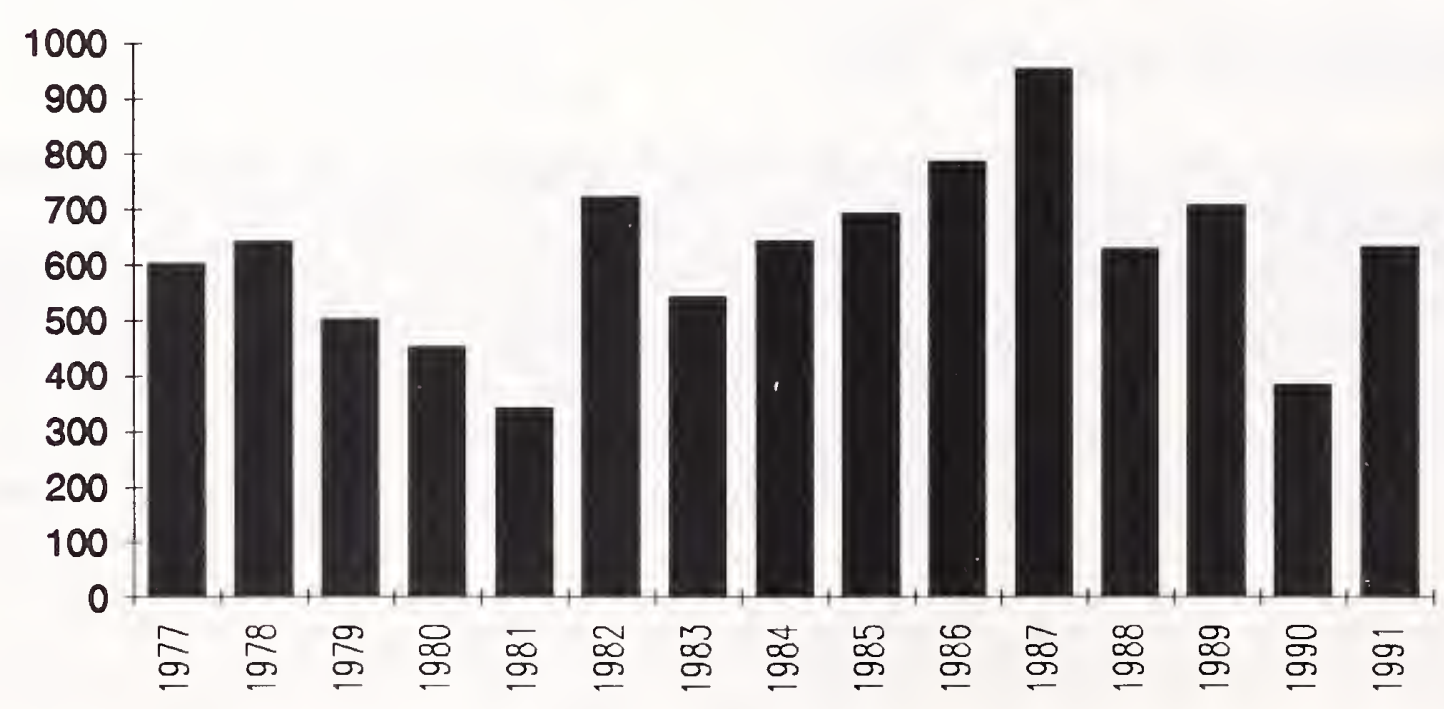


The management goal at the level of the population management unit is to achieve productive and biologically diverse naturally spawning populations that can support stock specific tributary fisheries above Lover Granite Dam and be compatible with carefully regulated mixed stock fishing in the Columbia River and the ocean. To do this, the population must also be compatible with mortality resulting from adult and juvenile passage through the mainstem after the region's best efforts to minimize these losses.

\section{Rebuilding target and schedule}

The Couneil aelnowledges the eonsiderable uneertainties and debate surounding the appropriate rebuilding sehedules and biologieat objectives. Hower, the Couneil believes it is important to establish an interim-objeetive for

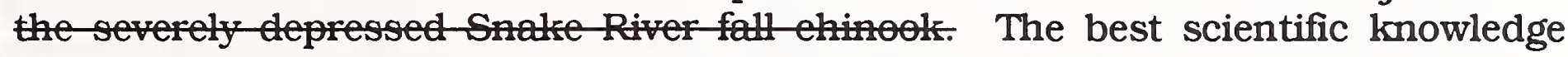
available at this time suggests that a minimum of 500 natural spawners are needed to meet the genetic needs of the run. The Council believes that a higher number is needed to assure sustainability and, if possible, a harvest in eastern Washington, eastern Oregon, and Idaho. In addition, the Council believes it is prudent in the early years of the rebuilding to estimate conservatively the effectiveness of measures until monitoring and evaluation reduce uncertainty. Based on this, the Council establishes a rebuilding target for Snake River fall chinook of 1,000 naturally spawning adult fish at Lower Granite Dam destined to spawn under natural conditions.

The Council establishes the following rebuilding schedule for Snake River natural fall chinook ${ }^{15}$ :

\begin{tabular}{|l|l|c|l|}
\hline & Low & Median & High \\
\hline Cycle 1 (1992-1995) & & 300 & \\
\hline Cycle 2 (1996-1999) & & 400 & \\
\hline Cycle 3 (2000-2003) & & 700 & \\
\hline Cycle 4 (2004-2009) & & 1,000 & \\
\hline
\end{tabular}

\section{(6) Biological Objectives}

To meet this rebuilding schedule, the Council believes that measures should be taken to make the following changes in survival rate at each life stage ${ }^{16:}$

15 Details of the rebuilding schedule including time frame and numeric targets will be projections based on information available at the time. Anaytical work necessary to do this is underway, but not yet completed. 
Needed improvement in survival rates

\begin{tabular}{|l|l|l|l|l|l|}
\hline & Egg-Smolt & $\begin{array}{l}\text { Juvenile } \\
\text { Passage }\end{array}$ & Harvest & $\begin{array}{l}\text { Adult } \\
\text { Passage }\end{array}$ & $\begin{array}{l}\text { Pre- } \\
\text { Spawning }\end{array}$ \\
\hline Cycle 1 & & $23 \%$ & $25 \%^{17}$ & $5 \%$ & \\
\hline Cycle 2 & & & & & \\
\hline Cycle 3 & & & & & \\
\hline Cycle 4 & & & & & \\
\hline
\end{tabular}

In eyele 2, the Couneit-expeets to meet the rebuilding sehedule through $a$ eombination of an inerease in juvenile and adult passege survival, habitat improvement, and-adjustments in harvest rate. In eyeles 3 and-4, the Couneil antieipates biologieat objeetives that require havest rates to be eonstrained to tevels no greater than those that ean be sustainel by Snake-River naturally spawing stoeks, simitar to those sustained by naturally spa ning upriver fall ehinook from the Hanford Reach of the Columbia River. Stubstantial improvents in juvenile-passage-survivl-will be required in the eyeles. The Cotneil will establish the biologieat objectives for eyeles 3-and-4 which meet the rebuilding sehedute in the third phase of the amentments.

\section{Rebuilding Strategies}

To achieve the rebuilding schedule will require aggressive action on several fronts. Snake River fall chinook populations are limited by mainstem passage survival, harvest, habitat degradation adverse interactions with hatchery fish and other factors. Rebuilding will require actions to address all of these factors. The Council recognizes this rebuilding schedule probably cannot be met with the measures in this program without supplementation. At the same time, the use of supplementation depends on a determination by the National Marine Fisheries Service and on genetic studies and supplementation policies specified in section A800 $\mathbf{A}$. If these factors indicate supplementation cannot be pursued at a level necessary to achieve this rebuilding schedule, the Council will review the biological objectives and program measures.

\section{Performance Standards}

The Council will track progress toward the rebuilding schedule through the Lower Granite Dam counts corrected for straying from hatcheries and

16 Biological objectives will likewise be set by analytical projections of based on available knowledge. These will be included in later drafts.

17 Phase II called for a $55 \%$ harvest rate on Snake River fall chinook relative to a $1984-90$ average of $73 \%$. This represents a $25 \%$ reduction in harvest. This does not necessarily equate to a like increase in survival. This number will be refined in future drafts. 
other sources. The Council will expect returns during each cycle to not fall below the low point in the rebuilding schedule table and provide the expected average over the time period. Returns below the projected low point for any cycle will trigger emergency Council review of its measures.

\section{Population Monitoring}

\subsection{Snate-River Fall-Ghinook (Phase 1)}

Bacliground: The fishery magers and tribes have agreed to end the trapping of Snake River fall ehinook at lee Harbor Dam and have agreet-on the need-to eonduet genetie studies of the population. They have not yet eoneluded diseussions on other features of a proposal to protect and rebuild fall ehinool.

\section{Measures:}

While the dam counts will provide important, timely information on progress, they integrate several possibly diverse populations of fall chinook. In so doing, important information about the status of these component populations can be lost. At the same time, it is not clear what, if any, separate populations exist for this population management unit, or how much natural production takes place below Lower Granite Dam. Snake River fall chinook also suffer due to our ignorance on life history, distribution, and limiting factors

a. Bonneville: Fund expeditiously studies to define the range, limiting factors and needs, especially in regards to flow and temperature, and provide basic life history information for Snake River fall chinook.

b.2.7(a) Bonneville: Fund studies to determine the genetic structure and population status of Snake River fall chinook (Phase 1).

c.2.7(b) Fishery agencies and tribes: Report to the Council on proposed Snake River fall chinook rehabilitation actions by September 10, 1991 (Phase 1).

\section{STUties ant eVaiuations (Phase 1)}

Baelground: While the-Couneil has put-emphasis on identifying aetivities that ean be undertaten imnediately to help salmon and steelhead in the short term, there also were proposals for-studies and evatuations, some of whieh would provide information that is eritieatin designing rebuilding efforts for weat stoetss. These studies-and evaluations were-of streh priority, the-Couneil believes, that 
their implementation should not wit for the eonelusion of the Couneil's more extented amentment proeesses.

\section{Measures:}

-4.4.1 Bonneville: Fund a study of the spawning and rearing habitats utilized by fall chinook salmon in the Snake River and examine factors influencing their migratory behavior (Phase 1).

(d) Development of rebuilding schedules for other populations.

In this document, the Council has provided targets and rebuilding schedules for Snake river spring, summer, and fall chinook. Achievement of these targets will contribute to the overall program goal. Similar rebuilding schedules should be developed for other populations in the Columbia basin.

Implementation process: Develop these rebuilding schedules utilizing input from the subregional teams identified in section A205. These schedules should closely mirror the structure and elements of the three rebuilding schedules provided above. As much as possible, they should reflect and incorporate the subbasin plans developed as part of the 1987 program. A schedule and workplan for development of the rebuilding schedules should be submitted to the Council by January 15, 1993. Development of rebuilding schedules should be prioritized based on the status and needs of the populations. Development should proceed in three phases for high, medium, and low priority populations defined on the basis of population status and need. Rebuilding schedules for high priority populations should be submitted to the Council for review and approval within sis months after Council approval of the overall schedule and workplan. Development of schedules for medium and low priority populations should be submitted respectively at six month intervals thereafter. As these rebuilding schedules are submitted, the Council will review the measures in this program for compatibility. Based on implementation experience, increased knowledge and improved techniques for projecting changes, the implementation process should be prepared to recommend modifications to the rebuilding schedules.

\section{A204 Performance Standards}

The effectiveness of actions is often uncertain and depends on other actions. It will be important for the Council and the region to track measures in a timely manner. Performance standards for each action or set of actions should provide an easily measurable index that relates to the type of biological or physical change intended. Performance standards are intended to provide a point of reference 
against which to monitor change, and units of measure to define change. Perfore They are not intended to state or limit obligations or to resolve technical uncertainties.

Performance standards will take a variety of forms. In some cases they will specify changes in survival when these are presently measurable; in others, they may relate to physical or qualitative changes, or relate to accomplishing certain tasks within certain time frames. Performance standards should be linked to the rebuilding schedules and biological objectives, and reflect changes needed to meet the biological objectives. They are not intended to be rigid and inflexible but should respond to new knowledge. As information improves, better performance standards may become apparent.

As part of the Fish and Wildlife Program, the Council will provide performance standards for the program goal and the rebuilding schedules. The program will also specify a process to define performance standards for each program measure and to monitor actions against the performance standards.

\section{(a) Program Goal}

Numeric increase performance standard: The performance standard will be the number of adult fish of all salmon species at Bonneville Dam plus estimated tributary returns below Bonneville plus harvest below Bonneville corrected for adult equivalents at the mouth of the river, relative to the 1981-90 average. The program monitoring report should provide an annual accounting of production relative to this performance standard.

Biological diversity performance standard: The performance standard will be the existing level of biological diversity. Existing biological diversity will be defined by a list of baseline populations against which populations will be compared annually. The baseline populations will be components of the population management units defined above. The natural processes of extinction and speciation will result in variation around the baseline over time. New knowledge may also indicate the need for revision in the baseline list of populations.

To establish the biodiversity baseline, the Council calls on the implementation planning process to convene an appropriate group of experts from the fishery agencies, tribes, and elsewhere to provide recommendations for the population list. A final recommended list of populations should be submitted to the Council by December 31, 1992. The program monitoring report should provide the annual list of populations and include a qualitative, and if possible, quantitative assessment of status and conditions 
for each population. The annual review will also include recommendations to modify the population list on the basis of new information.

\section{(b) Process for establishing additional performance standards}

Recommendations for additional performance standards for individual measures or logical groupings of measures should be developed through the implementation process. Implementing agencies and the fishery agencies and tribes should solicit input from the following groups to develop the concept of performance standards: Fish Passage Advisory Committee, Fish Transportation Oversight Team, Integrated Hatchery Operations Team, Regional Assessment of Supplementation Project, and the Technical Advisory Committee of the Columbia River Compact. The process should solicit input from other appropriate groups or individuals as well. Each existing group should review the program measures appropriate to its area of expertise and provide recommendations for performance standards. A final list of recommendation should be submitted to the Council by March 1 , 1993. Performance standards should reflect the program measures and biological objectives. The Council will review and act on these recommendations to provide a final set of performance standards.

\section{(c) Monitoring of performance}

As discussed in Section A205, tThe implementation process should provide an annual report of progress relative to the performance standard. This report should include recommendations for modifications to the set of performance standards. These recommendations will be reviewed by the Council.

\section{A205 Coordinated Implementation, Monitoring and Evaluation}

The Council recognizes the need to employ a systemwide approach to address the needs of Columbia River Basin fish and wildlife. To accomplish this, the Council believes a coordinated implementation, monitoring and evaluation process is essential. This should be flexible enough to evolve over time. It should facilitate identification of priorities. It should provide coordination at levels needed to accomplish basinwide as well as local watershed objectives. Coordination must also encompass all programs, plans, policies and statutes that affect fish and wildlife produced in the Columbia River Basin. It must allow all affected parties meaningful participation, encourage local implementation and guidance and provide needed regional coordination. The approach should also provide a mechanism for accountability. 
Considering all the functions that need to be addressed by coordinated implementation, monitoring and evaluation at both the regional and local level, it is easy to envision a complicated system of committees with frequent meetings and numerous assignments. The intent of the Council is to avoid this as much as possible this sort of approach. The Council expects coordinated implementation, monitoring and evaluation to become lean on process and heavy on implementation of on-the-ground actions for fish and wildlife. Standing committees and meetings should be kept to a bare minimum. When meetings are needed, existing groups and committee structures should be used. If existing committees are not appropriate for topics that need to be addressed, informal gatherings or ad hoc temporary approaches should be used to accomplish the need. The processes and committees that are created should be reviewed frequently to ensure their continuing need. In short, the Council intends that coordinated implementation, monitoring and evaluation should expedite, not burden, actions for fish and willdife.

\section{(a) Basin Oversight Group}

To-assist in this the-Council: Oversight Group, consisting of policy makers from the state and federal implementing entities and other interested parties, to aggressively pursue implementation of this program. The Basin Oversight Group will meet at least annually to addressen progress, problems and issues regarding program implementation. This group will review the annual implementation plan and the annual program monitoring report and make recommendations to the Council by July 31 of each year. Meetings of the Basin Oversight Group will focus on needed actions and implementation problems, not routine reporting. The Fish-Operations Exetive Com (deseribed in Seetion IIfAll committees identified in this program will be coordinated with the Basin Oversight Group.

\section{(b) Implementation and Monitoring.}

As the region moves forward to realize the ambitious goals of the fish and wildlife program it will pursue two closely related, parallel paths. One is the implementation path-othat is, taking specific actions identified in the annual implementation plan. This path will include steps to address uncertainties and refine actions over time. The second path is evaluation. The evaluation path will monitor overall program implementation, evaluate the effectiveness of actions taken, and judge their scientific merits. One outcome will be an annual assessment of the program's performance--the annual program monitoring report. This can be used to determine the need, if any, for changes in strategies or mid-course corrections. 


\section{(1) Implementation of Actions including Research Projects}

Implementation of this program is a complex process involving priorities, budgets, and allocation of effort. Bonneville, the fish and wildlife agencies and tribes deal with these complexities through the implementation planning process. In this process, the groups involved created a policy review group and a scientific review group to provide a forum for review of implementation questions. Coordination and prioritization of actions occurs in technical scoping groups that focus on different aspects of the program. This has been largely successful but is limited by the fact that it deals solely with Bonneville-funded projects. The Council sees a need for an approach that coordinates all implementation actions. Implementation must also explicitly deal with uncertainties associated with the success of the actions. Uncertainties need to be identified for each measure and dealt with as actions are implemented. It is expected that this can best be accomplished by an expansion of the existing implementation planning process to accommodate other implementing agencies and programs rather than creation of an additional separate process.

BonNeville, Fish and wildLIFE agencies and TRIBes: Expand the implementation planning process to provide a forum for implementation of all program measures, including research, identification and prioritization of actions to address uncertainties, and for discussion of cost sharing and regional coordination. This process should prepare a draft annual implementation work plan detailing actions by all implementors in response to program measures. A key feature of the expanded implementation process is that actions should address uncertainties and lead to refinement of the program. This should proceed from an independent, scientifically based identification of uncertainties associated with program measures. This list of uncertainties should be refined over time as some are resolved and others become apparent. All actions implemented to address program measures should recognize and explicitly deal with these uncertainties through specific research, implementation, or monitoring. Results should be made available through the Coordinated Information System, and other measures in Section A900. Where change in the program is indicated, the results should be summarized and discussed with the Basin Oversight Group. Participation in this process should include the fish and wildlife agencies, tribes, Bonneville, river operators, land and water managers, utilities, citizen groups, Council and others. It should include full participation by the National Marine Fisheries Service to provide coordination with Endangered Species Act recovery activities.

(2) Monitoring 
While implementation seeks to take actions and clarify uncertainties, program monitoring seeks to determine if the Council's goals are being met and runs are being rebuilt. It also provides scientific review of the program and a means to interject creative thinking, innovation and new ideas. Measures below describe a procedure to assess implementation and progress, and evaluate the program on its scientific merits. The program monitoring component will provide the Council with information addressing the following questions:

- Are measures being implemented?

- Are performance standards being met?

- Are biological objectives being met?

- Are rebuilding schedules being met?

- Are program goals being met?

- How are effort and money being allocated?

- Are there unintended effects on other aspects of the environment?

An annual program monitoring report should provide an objective, scientifically credible summation of the facts associated with these questions. The Coordinated Information System (Section A900) should provide the information necessary for this report. Independent scientific review should identify the scientific merits of the program and its implementation.

BONNEVILLe, FISH AND WILDLIFE AGencies AND TRIBes: As part of the expanded implementation planning process, fund and coordinate preparation of an annual program monitoring report and its independent, scientific review. This should be based on the work of the Council's Monitoring and Evaluation Group to date. This will replace the Monitoring and Evaluation Group. Preparation of the annual monitoring report should include broad technical participation including the Council and the National Marine Fisheries Service. Bonneville should supply funds necessary to support this effort.

BonNeville: Fund the scientific review of the program measures and their implementation as a means of achieving the Council's goals. Selection of reviewers should be made in consultation with the Council and other participants in the implementation process. The review should be independent of institutional constraints and biases and deal with the scientific merits of the region's efforts. The basis for this review should be the annual monitoring report. This review should also suggest innovative ideas, techniques, and suggestions that might contribute to the success of the Council's program. The first of these reviews should be completed 
within one year of adoption of this rule. Subsequently, reviews should occur at least biennially.

\section{(3) Annual Implementation Plan and Annual Program Monitoring Report}

Fisheries Agencies, Tribes and Bonneville: Submit draft Annual Implementation Plan and draft Annual Program Monitoring Report to Council for review by June 15 of each year. After Council approval, appropriate entities fund implementation.

\section{(4) Subregional Planning}

On June 1, 1991, the fisheries agencies and Indian tribes of the Columbia Basin Fish and Wildlife Authority submitted the Integrated System Plan for Salmon and Steelhead Production in the Columbia River Basin to the Council. The building blocks for the Integrated System Plan are the 31 subbasin plans prepared for each of the major subbasins or watersheds of the Columbia River Basin that produce salmon and steelhead. These plans, along with other resource management plans, will form the basis for identifying priorities and guiding implementation of the fish and wildlife program. Plans developed under the program, and otherwise, will be used to address other fish and wildlife species.

Fish and Wild dife Agencies, Tribes and Bonneville: Form subregional teams to assist in implementation of fish and wildlife measures in the following subregions of the Columbia River Basin.

- Below Bonneville Dam

- Bonneville Dam to Priest Rapids Dam

- Priest Rapids Dam to Chief Joseph Dam

- Above Chief Joseph Dam

- Snake River from mouth to Hells Canyon Dam

- Above Hells Canyon Dam

Participation on the teams should include appropriate fish and wildlife agencies, tribes, utilities, Bonneville, land and water managers, private landowners, citizen groups, Council, and others. For each subregion, the teams will use the Integrated System Plan, subbasin plans, other fish and wildlife plans and any other available relevant plans and information to prepare recommendations for the Annual Implementation Plan and the 
Annual Program Monitoring Report. Each team will be responsible for identifying any conflicts with other resource management plans in the relevant subregion along with options for resolving these conflicts. Recommendations should:

- identify population management units and indicator stocks

- coordinate actions to meet rebuilding schedules and review progress

- describe actions to maintain and rebuild fish and wildlife populations

- reflect and be consistent with the program measures; goals; habitat goals, policies and performance standards; survival rate objectives; and treaty rights

- identify actions to be taken, implementing entities, and implementing timeframes

- include monitoring provisions needed to evaluate the success of plan actions and to assure that actions are taken and timeframes are met

- be presented to the Council and the implementation process by April 15 of each year. 



\section{SECTION A300}

\section{MAINSTEM FLOW, VELOCITY AND TEMPERATURE IMPROVEMENTS}

Salmon and steelhead begin and end life in many diverse streams and tributaries throughout the Columbia River Basin, but they all eventually share one route. They must make their way down and ultimately back up the mainstems of the Columbia and Snake rivers as they go to and from their spawning beds. Between passages, they spend most of their adult lives in the Pacific Ocean.

Given that their unusual life cycle depends on a long river journey that can stretch hundreds of miles, it is clear that safe passage is paramount to their survival. Downstream passage is especially dangerous. The juvenile fish face two major obstacles. First, dams are obvious physical barriers. Fish that pass through turbines have a significant mortality rate. Second, the fish are on a biological timeclock as they adapt from fresh to salt water. To reach the ocean safely, the spring migrants must complete their downstream journey quickly. The operation of dams and reservoirs has altered river levels and flows, slowing and sometimes stalling the fish as they travel downstream. These delays also expose fish to predators, disease and high water temperatures.

From the start in 1982, the Council's program recognized and focused on the importance of improving mainstem survival for both smolts and returning adults. However, in recent years, the problem has been exacerbated by a series of low water years, caused primarily by drought conditions in the southern and eastern parts of the basin. The Snake River Basin has been particularly hit hard. It is believed that this situation contributed significantly to a reversal in the progress to rebuild runs that had been made in the early 1980 s.

The Council has heard from many sources, including fishery managers and utilities, that the current program's water budget and mainstem improvements are not adequate. Frankly, there is considerable controversy about the effectiveness of existing and proposed mainstem survival measures. At present, it is unlikely that the region will find complete consensus in this area, but regional acceptance of measures is critical.

It would be a serious mistake to use lack of consensus or inadequate data as a reason to take no action. By the time the data is in and everyone agrees to its interpretation, it could be too late for certain runs. 
The region can and must select and implement the best available measures. Given the incompleteness of explicit data about the effectiveness of measures, the region will have to try some experiments. Careful monitoring and evaluation of results will be essential. Those experiments that show results should lead to sustained implementation of actions, while those that produce no results should be terminated before the region has wasted a major investment.

This willingness to take actions in the face of uncertainty, to conduct experiments to test what does and does not work, and to alter course accordingly, as monitoring indicates, is known as adaptive management. Adaptive management will remain a cornerstone of the Council's program.

The measures that are selected and added to the program will need to address all facets of mainstem survival including fish passage facilities at the dams, flows between the dams, spills of water over the dams, predation control and juvenile fish transportation. They also must set performance standards to promote actions that will increase salmon survival over the longer term.

In 1991, the Salmon Summit succeeded in identifying a number of ways to manage the river system to provide additional water for salmon and steelhead. This proposal goes beyond that and calls on the region to take further steps beginning in 1992, and to commit to explore and implement major, additional actions to further improve migration conditions beyond 1992.

The actions outlined in this section identify measures that can and should be implemented immediately. Enhanced flows and reservoir drawdowns to improve water velocity appear to be the most promising way to speed inriver fish migration. Speedier passage should reduce predation and water temperature problems that lead to fish mortality.

However, the Council is not choosing inriver migration to the exclusion of options such as transportation. The Council has not found sufficient biological evidence on which to make such a choice. It is choosing to use either or both, as long as they are consistent with improved survival. The Council is proposing to improve conditions for survival in both modes of migration to the greatest extent practicable.

The Council has established a process to address potential trade-offs between the flow needs of Snake River spring and summer chinook and fall chinook based on limited water storage capacity and availability of water at appropriate temperatures. Fishery managers and river operators should consider the benefits of proposed measures for weak stocks. and the cost to other stocks and river users. Lower water temperature may be important to the survival of fall chinook, and it will be affected by the source of mainstem flows (e.g. cold water reservoirs) as well as other factors such as local watershed conditions. 
The approach to mainstem survival must be multi-faceted. Flows and reduced temperatures alone are not sufficient. Control of predation, improved and/or new fish transportation methods, and completion of programs to install and upgrade screens at both the dams and all unscreened diversion inlets are all vital to successful mainstem passage.

The Council believes that reservoir drafting holds great promise as a strategy for improving river velocities in the lower Snake River and increasing the survival of the Snake River salmon smolt migration. The reservoir drafting strategy, as well as additional measures, will be fully developed, demonstrated, tested expeditiously and evaluated for quick implementation unless shown to be structurally or economically infeasible, biologically imprudent or inconsistent with Sections 4(h)(5)-(7) of the Northwest Power Act.

Finally, and not at all least, measures designed for salmon must take into account the effects on resident fish and wildlife, especially endangered species, other uses of the river system, as well as impacts on the Northwest economy.

Development of the dams for hydroelectricity, flood control and other purposes on the Columbia and Snake rivers has greatly altered the natural flows and cross-sectional areas of rivers in the basin. The spring runoff is stored in reservoirs to be used during periods of naturally low flows. Regulating the river in this fashion increases its ability to produce electricity as well as to provide for irrigation, transportation, recreation and flood control throughout the year. However, this and other uses also reduce river flows, particularly during the spring when juvenile salmon and steelhead are migrating downstream to the ocean.

The combination of reduced flows and the greater cross-sectional area of the river due to reservoir storage slows the juvenile fish as they migrate from their area of origin to the ocean. This increase in travel time affects the ability of the juvenile salmon to make the transition from freshwater to saltwater and increases their exposure to predatory fish and birds. Reduced flows also endanger juvenile salmon by raising water temperatures, altering water chemistry and increasing susceptibility to disease.

The physical problems faced by salmon and steelhead have been compounded by the diversity of the parties involved in the river basin's management. Even with major efforts to increase the amount of water for salmon and steelhead, matching water supplies with the needs of spring and summer migrating fish poses a substantial problem of analysis and coordination.

Based on the best information available today, the existing water budget must be supplemented with substantial new flow, velocity and temperature 
improvements. To do so in the short term, the region must make better use of existing water supplies and facilities. In 1991, the region demonstrated the ability to find additional water for spring and summer migrants, and achieved promising results in reducing temperatures for adult fall chinook in the lower Snake River. These efforts must be continued and expanded, beginning in 1992.

To augment flows for Snake River spring migrants, the Council calls for lower Snake River reservoirs to be operated at near minimum operating pools, and for major storage contributions from Dworshak reservoir, the Hells Canyon complex, and projects in the Snake River Basin. The same projects are called on to supply water to address water temperature problems for Snake River adult summer migrants (fall chinook). If there is a conflict between operations for spring and summer Snake River migrants, the Council calls for the conflict to be resolved by the Fish Operations Executive Committee in consultation with the National Marine Fisheries Service.

For Columbia and Snake river spring migrants, the Council is calling for the John Day reservoir to be operated at a lower than normal level, and for substantially augmented flows, in addition to the existing water budget. For summer migrants, the Council calls for additional flows to be made available, and for Bonneville to continue to seek energy exchanges and other power system operational changes to help increase flows. Because these measures are expensive and often controversial, the Council calls for careful monitoring of their biological effectiveness. The Council will consider modification if biological data so indicates.

The Council believes that these measures, taken together, should improve survival for Snake and Columbia river sockeye, and spring, summer and fall chinook. However, the region needs expanded options for improving the survival of juvenile fish migrating in the river, both in the short-term and the longer term. For the short term, the Council calls for a Fish Operations Executive Committee described in Section A302., to develop accounting procedures to improve the management of water for fish in the Snake and Columbia rivers. This committee should seek ways to make current operations more responsive to the needs of fish. The Council welcomes recommendations from these groups, or others, for improvements in the flow program. The Council supports analyses of alternative ways to accommodate increased flows for fish.

The Council also calls for demonstration, testing and evaluation of measures to achieve yet higher levels of mainstem protection in the longer term. Over the coming two years, the region must explore structural and nonstructural improvements such as reservoir drawdowns, new storage, water use efficiency improvements, and new approaches to power system operations, such as seasonal exchanges. Unless they are structurally or economically infeasible, biologically 
unsound, or inconsistent with Sections 4(h)(5)-(7) of the Northwest Power Act, these measures should be implemented expeditiously.

\section{A301 Performance Standards}

\section{(a) Snake River}

\section{(1) Spring migrants}

Incorporate the measures described below into firm power planning. Figure 8 illustrates the approximate flows attained when these measures are applied to the historical water record.

\section{(b) Columbia River}

\section{(1) Spring migrants}

In addition to the existing water budget volume, provide up to three million acre-feet of water for spring migrants subject to conditions specified below.

\section{B. Meastures}

\section{A302 River operations}

Through an annual policy and technical process, the region will address flow and temperature regimes and reconcile measures described below to achieve protection for salmon and steelhead. The process will be initiated by the Council and managed by the Fish Operations Executive Committee, which will be appointed by the Council and made up of senior management representatives of the Council, as well as power and fishery interests.

This Executive Committee should conduct a meeting process that results in a detailed, annual Implementation Plan. Insofar as practical, the meeting process should incorporate matters such as spill, transportation, the Corps' annual Fish Passage Plan, the fishery agencies' and tribes' Detailed Fishery Operating Plan, annual operating plans for the Non-Treaty Storage Fish and Wildlife Agreement, planning for coordinated system operations, Idaho Power Company's proposed operations under its weak stock plan, water identified by the Snake River Anadromous Fish Water Management Office. spring-fall trade-offs. research and monitoring results, and other mainstem passage matters.

These river operations meetings should identify all water available in a particular year, and plan for its use. During low flow conditions, when the monthly average flow equivalent of 85.000 cubic feet per second in the Snake 
River cannot be provided for the full migration period, flows should be distributed to protect a portion of all known naturally-produced stocks. The plan will have the flexibility to move flows between May and June if such shaping is more likely to achieve the intent of this program. If there are conflicting water demands among anadromous species, conflicts should be resolved by the Fish Operations Executive Committee in consultation with the National Marine Fisheries Service.

All alterations in river operations undertaken pursuant to these amendments should consider impacts on resident fish and other species, especially threatened, endangered or native species, and should seek to avoid adverse effects to those species. The meeting process should produce an operating plan by March 31, but will need to begin in the preceding year to complete its work.

The Fish Passage Center should manage water supplies for fish in accordance with the annual Implementation Plan. In order to assist the full range of stocks migrating in the Snake and Columbia Rivers, it is imperative every effort be made to shape water stored for fish flow augmentation to the fullest extent practicable. Any proposed deviations from the Implementation Plan must be approved by the Executive Committee. Therefore, the Executive Committee must develop a procedure to address fish flow operations throughout the fish migration season, if necessary.

Accounting procedures for the use of this water will be developed under the auspices of the Fish Operations Executive Committee and provided to the Council and other interested parties by March 31, 1992. The Fish Passage Center will be directed by one fish passage manager appointed under the joint authority of the fish and wildlife agencies and Indian tribes. All water supplies acquired under measures below will be applied to the fish migration.

The Council welcomes proposals from river operators, especially those that emerge from the River Operations Process described above, for better ways of providing equivalent amounts of water for salmon and steelhead, within time frames specified in this amendment. Any such proposals should be submitted to the Council and, on approval, implemented.

The phase two rulemaking was conducted on an expedited basis so that the 1992 migrations of juvenile and adult salmon and steelhead in the Columbia River Basin will receive the benefit of many of its measures. Some of the salmon and steelhead stocks in the basin are in a weak condition and will continue to decline unless the region takes immediate comprehensive action.

In addition, the National Marine Fisheries Service is now beginning to assess the recovery actions necessary for the Idaho stocks that have been listed or proposed for listing. The Council believes that the region's timely adoption of the 
measures in this rulemaking will be an important factor in the preparation of a recovery plan by NMFS.

However, the Columbia River and its tributaries make up an extremely complex operating system. The Council recognizes that the flow, velocity and temperature improvement measures contained in this amendment will have a substantial impact on the operations of this system.

Given more time and experience, it is likely that additional refinement of these measures can be achieved, resulting in greater operational efficiency and better coordination between the needs of fish and other uses of the river. Furthermore, the next phase of this process (phase three) is likely to provide new information about the adequacy and appropriateness of the measures adopted in the phase two rulemaking and will require decisions about how phase three measures should be integrated with those adopted in phase two.

The Council expects river operations for fish beginning in 1992 to be in accordance with these measures as they are now written. The Council will carefully monitor these operations, and will welcome suggestions from all interested persons on how they can be improved. In the fall of 1992 and of each subsequent year until further notice, the Council will review the operations. At that time, it will determine whether these measures should be revised to provide the intended benefits to fish in the most practical and efficient manner.

\section{A303 Snake River}

\section{(a) Spring migrants}

Use the following measures to aim to provide a minimum monthly average flow equivalent ${ }^{18}$ of 85,000 cubic feet per second at Lower Granite in all water years from April 16 through June 15. Figure 8 illustrates the approximate flows attained when these measures are applied to the historical water record.

CORPS OF ENGINEERS:

Unless drawdown experiments require otherwise, reduce the level of Lower Granite, Little Goose, Ice Harbor, and Lower Monumental pools to near minimum operating pool levels when juvenile fish begin migrating (typically about April 16). The Fish Operations Executive Committee will plan for refill between the end of the juvenile fall chinook migration and the beginning of the adult fall chinook migration. Ensure that refill does not reduce the effectiveness of temperature control measures. At present, near minimum operating level is assumed to be one

18 "Flow equivalent" means the flow level required to achieve the same water particle travel time as $85.000 \mathrm{cfs}$ at average normal pool elevations at all projects. For example, $81.000 \mathrm{cfs}$ at minimum operating pool elevations is the flow equivalent of $85,000 \mathrm{cfs}$ at average normal pool levels. 
foot above the minimum operating elevation. Identify and report to the Council by March 15, 1992, any measures which can be implemented promptly to remove limiting conditions and allow operations at a lower level without adversely affecting present users.

(2) Bonneville, Corps of Engineers, Bureau of Reclamation and other RELEVANT PARTIES:

Operate the Dworshak reservoir to improve salmon migration conditions consistent with the measures listed below:

a. From January to April 30, in years when Snake River runoff is forecast to be below average, shift system flood control storage space to other Columbia Basin projects.

b. Dworshak should be as close as possible to its upper rule curve by April 15 of each year.

c. When the official April forecast for the April-July runoff at Lower Granite is less than 16 million acre-feet. Dworshak will provide 900,000 acre-feet of water plus any water gained from the flood control shift for juvenile fish flow augmentation. This volume of water is in addition to any minimum flow release requirements at Dworshak. When the runoff forecast is greater than 16 million acrefeet and less than 29 million acre-feet, Dworshak will provide all available water, including any water gained from the flood control shift, for juvenile fish flow augmentation, while providing a 70 percent confidence of refill by July 31 . When the runoff forecast is 29 million acre-feet or more, augmentation from Dworshak is not required.

d. Dworshak's outflow is limited to 25,000 cubic feet per second during the migration period.

e. In emergency situations, for capacity needs, Dworshak may be temporarily used to respond until arrangements can be made to continue filling toward the upper rule curve.

(3) BUREAU OF RECLAMATION AND STATE OF IDAHO:

Use uncontracted storage space to supply at least 90,000 acre feet of water for spring migrants. 
(4) Bureau of Reclamation, states of IdAHo and OREgon, BonNeVille, and OTHER RELEVANT PARTIES:

Unless the forecast April through July runoff at Lower Granite exceeds 29 million acre-feet, use water efficiency improvements, water marketing transactions, dry-year option leasing, storage buy-backs, and other measures to secure at least 100,000 acre-feet of water from the Snake River Basin for spring migrants. Of this amount, half should be secured by the Bureau of Reclamation, and half should be secured with financial.incentives provided by Bonneville (through the Idaho Water Rental Pilot Project, or such other process as the Bureau of Reclamation, Idaho, Oregon and Bonneville choose).

BONNEVILLE:

Fund an independent, third-party evaluation of the effectiveness of these measures in providing water for salmon and steelhead.

(6) IdAHo POWER COMPANy, CORPS of Engineers, Bureau of REClamation, and FEDERAL ENERGY REGULATORY COMMISSION:

a. Operate Brownlee reservoir to ensure that water described in paragraphs a(3) and (4), above, is passed to assist spring migrants. Report to the Council each year during the River Operations process (Section A302) on the Idaho Power Company's effort to shape this water.

b. Unless the forecast April through July runoff at Lower Granite exceeds 29 million acre-feet, draft Brownlee reservoir during May to a minimum elevation of 2,069 feet, which will provide a maximum of 110,000 acre-feet for spring migrants whenever sufficient inflows are forecast so that resident fish, fall chinook and Brownlee refill by July 1 will not be significantly affected. In years when Snake River runoff is forecast to be below average, shift system flood control storage space from Brownlee to other Columbia Basin projects whenever possible and needed.

(7) BUREAU OF RECLAMATION, STATES OF IDAHO AND OREGON:

Establish, in cooperation with fish and wildlife agencies. Indian tribes and interested parties, a Snake River Anadromous Fish Water Management Office to facilitate the use of water from the Snake Basin. Report to the Council by May 1992. 
(1) CORPS OF ENGINEERS, BONNEVILLE AND OTHER INTERESTED PARTIES:

a. Continue to release cool water during August and September from both Dworshak and the Hells Canyon complex dams to reduce lower Snake River water temperatures for adult fall chinook salmon and steelhead and evaluate the effectiveness of this measure. The objective of this evaluation is to target reduced water temperatures at Ice Harbor Dam by September 1 of each year, and to determine the effectiveness of these operations on adult fish passage through the lower Snake River. Report results of this evaluation to the Council by December 1993. Policy and technical guidance for determining the magnitude and timing of Snake River temperature control releases from Dworshak and Brownlee should be provided in a July meeting of the Fish Operations Executive Committee.

b. If Dworshak reservoir is full or nearly full by the end of July, draft Dworshak reservoir up to 20 feet in August as needed for the temperature control evaluation. In September, beginning immediately after Labor Day, release up to 200,000 acre-feet of additional cool water from Dworshak reservoir, as needed for the temperature control evaluation. If Dworshak reservoir is not full, use of Dworshak for temperature control will be addressed in the July meeting of the Fish Operations Executive Committee.

\section{(2) All PARTIES:}

Seek funding assistance for necessary modifications to recreational and commercial facilities to allow Dworshak reservoir to operate at reduced levels to improve survival of fall chinook consistent with the mitigation provisions of these amendments (see Section A1000).

(3) IDAHO POWER COMPANY AND FEDERAL ENERGy REgulatory COMMISSION:

a. Modify operation of the Hells Canyon complex to provide coordinated fall and spring flows below Hells Canyon Dam to maintain fall chinook spawning, incubation and emergence. Evaluate options for providing more water for fish flows from Brownlee reservoir, including substantially improved ability to shape water from the Snake River Basin for spring and summer migrants, and report to the Council by the end of 1993.

b. During July, draft Brownlee reservoir to a minimum elevation of 2.067 feet, to provide up to 137.000 acre-feet for the juvenile fall chinook 
migrants. Refill this space in August with water from the Snake River Basin. The amount of July draft at Brownlee is subject to the availability of water in (4) below.

c. During September, draft 100,000 acre-feet from Brownlee reservoir to help reduce Snake River water temperatures for adult fish passage. In addition, pass 100,000 acre-feet of water from the Snake River Basin through the Hells Canyon hydropower complex.

(4) Bureau of Reclamation, State of IDAHo, BonNeVille and other RElevant PARTIES:

Use water efficiency improvements, water marketing transactions, dry-year option leasing, storage buy-backs, and other measures to provide up to 137,000 acre-feet of water to refill the Brownlee reservoir in August, in light of the operation described in (3)b, above, and to provide 100,000 acre-feet of water to reduce water temperatures (see (b)(3)c, above). Of this amount, half should be secured by the Bureau of Reclamation, and half should be secured on a matching basis using financial incentives provided by Bonneville (through the Idaho Water Rental Pilot Project, or such other process as the parties choose).

\section{BONNEVILLE:}

Fund an independent, third-party evaluation of the effectiveness of these measures in section (4) above to provide water for salmon and steelhead.

\section{A304 Columbia River-Spring Migrants from May 1 through June 30t.}

(a) Spring migrants

BONNEVILLE, CORPS OF ENGINEERS, BUREAU OF RECLAMATION AND OTHER RELEVANT PARTIES:

(1) Beginning immediately, operate John Day Reservoir at minimum irrigation pool from May 1 to August 31 of each year. Minimum irrigation pool is the lowest level at which the irrigation pumps drawing from the reservoir will operate effectively. Monitor and evaluate the biological benefits of John Day Reservoir operations so that the Fish Operations Executive Committee can gain better information to determine in future years how the operations can complement flow velocities and other factors to achieve biological objectives. The Council recognizes that, as was the experience in 1991, under certain conditions. a slightly higher elevation may be required and that some daily flexibility is necessary for operation of the reservoir. Other portions of this rule contain measures that will permit irrigators and other users of the John Day Pool to 
operate effectively at lower pool levels. The Council expects the level of the minimum irrigation pool to be lowered as these measures are implemented. The Council expects that this will be accomplished by 1994. The intent of this provision is for the John Day reservoir to be operated at the lowest practical level during the spring and summer migrations of juvenile chinook and sockeye salmon.

(2) When the adjusted April forecast for the January-July runoff at The Dalles is less than 90 million acre-feet, have water in storage and available for juvenile fish flow augmentation by April 30. The appropriate volume is derived from the curve in Figure 9 based on the official April forecast, adjusted to the National Weather Service 95 percent confidence level. This volume is in addition to the existing water budget volume. When applied to the lowest 20 water years in the historical water record, this volume of water would provide approximately the flows shown in Figure 10.

(3) Actions taken to store the required volume should not violate the following conditions:

(a) Flood control limitations.

(b) Daily reservoir drawdown or refill limits.

(c) Vernita Bar Agreement requirements, which protect fall chinook below Priest Rapids Dam.

(4) BONNEVILLE:

Beginning in January of each year, provide to the Council and other interested parties a written monthly report of the volume of water stored pursuant to Sectopm A304(a)(2) above. By April 30th of each year, identify the location and total volume of water stored for juvenile fish flow augmentation.

(5) CORPS OF ENGINEERS:

Provide to the Council and other interested parties a written monthly report on where system flood control storage is being provided, including a summary of system flood control shifts.

(6) Whenever flow augmentation measures are in effect, the weekend and holiday average flows should not be lower than 80 percent of the average of the five preceding weekdays. 
(7) The 140 thousand cubic feet per second flow cap in the mid-Columbia River is removed.

(8) BONNEVILLE:

Because of the uncertainty in the supply of out-of-region energy, immediately secure options for one or more resources to augment reduced hydroelectric energy during winter months. If the region is unable to store enough water for any reason other than those specified in (2), above, immediately begin to acquire the optioned resources called for under Objective 2 of the Northwest Conservation and Electric Power Plan, or otherwise acquire resources that are consistent with the plan, in an amount sufficient to ensure that the full volume of required water is available in succeeding years. The Council will consult with representatives from all interested parties to determine the proper amount and timing of the acquired resource(s).

\section{(b) Columbia River Summer Migrants}

\section{(1) BONNEVILLE:}

In July and August in below average water years, provide a volume of water from the U.S. Non-Treaty Storage water available in that year to facilitate evaluations described below.

(2) BONNEVILLE, FISHERY MANAGERS:

Evaluate the effectiveness of summer flows in improving passage conditions and survival for summer migrants.

(3) BONNEVILLE:

Continue to seek energy exchanges and other energy alternatives with potential to increase Columbia River flows in July and August to facilitate evaluations and improve survival of summer migrants.

\section{A305 Snake River Reservoir Drawdown Strategy}

The region must expand existing options for improving survival of juvenile fish migrating in the river. In this section, the Council identifies actions necessary to develop, demonstrate, and implement a reservoir drawdown strategy for the lower Snake River. This strategy is intended to provide inriver juvenile migration conditions that will promote rebuilding of imperiled Snake River anadromous fish stocks. Snake River transportation and flow augmentation measures, described in section 6 below, will be pursued pending implementation of the Snake River reservoir drawdowns. Such drawdowns will be implemented to achieve biological 
objectives unless they would be structurally or economically infeasible, biologically imprudent, or inconsistent with Sections 4(h)(5)-(7) of the Northwest Power Act. The Council will review and re-evaluate transportation and flow measures upon receipt of final reservoir drawdown plans. It is the intent of the Council that these measures will be in addition to or complement measures already initiated in order to achieve biological objectives.

The region needs to evaluate these actions to identify biological benefits for weak stocks and strategies to mitigate adverse effects on other river users. Parties conducting tests and evaluations should report progress to the Council no less than semiannually, beginning May 30, 1992, and submit interim reports by November 1, 1992 and final reports by November 1, 1993. The results will be reviewed by the Council as soon as available to develop the best strategy to meet biological goals and objectives. The Council will provide for public involvement prior to its decision on the drawdown strategy. It is the intent of the Council to have the Snake River drawdown strategy implemented by April 1995 unless shown to be structurally or economically infeasible, biologically imprudent or inconsistent with Sections 4(h)(5)-(7) of the Northwest Power.Act.

(a) An integrated, multi-disciplinary planning effort is necessary to demonstrate and develop the Snake River reservoir drawdown strategy. The development of the reservoir drawdown strategy will focus on the four lower Snake River projects and will include an Operations Plan, Design Plan, Mitigation Plan and Biological Plan. The plans will determine the best method for implementing the reservoir drawdown strategy while mitigating impacts to other users of the river.

\section{(b) Bonneville and the Corps:}

In consultation with the fishery managers of the Snake River Basin, starting as early as possible in 1992, conduct any tests necessary to assist in the formulation of the plans called for in this measure.

\section{(c) Council, Bonneville, Corps, and Bureau of Reclamation:}

Establish a committee to coordinate analyses conducted by the federal agencies and oversee the development of the plans described in this section. The committee, chaired by the Council, will consist of a representative of the Corps, Bonneville, Bureau of Reclamation, Idaho, Montana, Oregon, Washington, and Indian tribes. The committee's work will facilitate regional involvement in ongoing federal processes relating to lower Snake River reservoir drawdowns and will help prevent unnecessary duplication between federal and Council-sponsored efforts. The Council will provide ongoing coordination with other interested parties in the region, and will be responsible for overseeing the development, scheduling and completion of the plans called for in this section. 


\section{(d) Bonneville:}

In coordination with the committee, fund independent technical resources as needed to enable the committee to review the adequacy of analyses conducted by the federal agencies and to conduct their own analyses when the committee or the chair deem appropriate. Funding will be based on a scope and plan of work approved by the Council as soon as possible but not later than its February 1992 meeting.

\section{(1) Operations Plan}

The Operations Plan will consist of a detailed program for the implementation of reservoir drawdowns and will include, but is not limited to the following elements:

a. Criteria for depth and duration of drawdown;

b. The sequence in which reservoirs will be lowered and refilled;

c. Rates of drawdown and refill;

d. Provisions for refilling mainstem reservoirs following the drawdown period;

e. Plans for using water evacuated from the mainstem reservoirs to enhance downstream flows for fish migration;

f. Operations required for juvenile fish passage;

g. Operations required for adult fish passage;

h. Evaluation of shifting flood control responsibilities during drawdown period to the lower Snake River projects and among storage projects in the Columbia River Basin in order to provide additional storage at other projects; and

i. Procedures for planning, coordinating and implementing reservoir operations.

\section{(2) Design PLAN}

The Design Plan will consist of a feasibility analysis, preliminary design work, and preliminary cost estimates for structural modifications needed to implement the Operations Plan. The Design Plan will be developed in conjunction 
with the Operations Plan. The Design Plan will consider measures to permit operation of the following facilities at lower reservoir elevations:

a. Adult fishways;

b. Turbines and associated facilities;

c. Turbine intake screens and fish bypass facilities;

d. Collection and transportation facilities for juvenile migrants;

e. Physical devices and other measures to control nitrogen gas supersaturation and any other conditions such as sedimentation that may be associated with reservoir operations; and

f. Any additional design activities necessary to evaluate the modifications needed to facilitate implementation of the mitigation provisions of this amendment.

\section{(3) Mitigation PLAN}

The Mitigation Plan will consist of measures to mitigate the impact of the reservoir drawdown strategy to the extent practicable. The Council anticipates that reservoir drawdown will have both economic and environmental impacts. Mitigation of these impacts is an integral and necessary part of any overall changes which would involve such drawdowns. Consistent with the mitigation section of these amendments (Section A1000), the costs of mitigating impacts should be shared regionally and/or nationally so that local communities, industries, businesses and other entities that depend on the Snake River do not bear a disproportionate share of the burden. Development of the Mitigation Plan should proceed concurrently with development of the Operations and Design plans. The plan should address:

a. Stability of bridges, railways, levees and other structures that may be affected by implementation of the Operations Plan;

b. Impact of reservoir drawdown on the economic sectors affected by disruption of barge traffic on the lower Snake River; shifting lock maintenance operations into the drawdown period; alternative navigation and commodity shipping strategies; construction of additional storage facilities for products of commerce; measures to facilitate other means of transportation; relief for increased shipping costs; loss of market access; and other measures; 
c. Impacts of reservoir drawdowns on resident fish, wildlife (particularly threatened or endangered species), recreational users and the recreational industry, and other environmental values;

d. Impacts on irrigation, including cost and other requirements necessary to relocate irrigation pipe inlets and to supply water; and

e. Impacts on county, state or federal roads and transportation corridors.

(4)

\section{BIOLOGICAL PLAN}

The Biological Plan will analyze the effects of pool drawdown on salmon, steelhead, resident fish and wildlife. This should include the analysis of available information and any new information that results from interim tests. The effects of drawdown on fish survival should be compared to alternative means to enhance survival. The Biological Plan should be coordinated with the Design and Operations plans, particularly in regard to development of drawdown alternatives.

(5) By November 1, 1992, interim plans prepared pursuant to this section should be submitted to the Council for review and approval. At that time, the Council will establish an implementation schedule for further steps in the development of a reservoir drawdown program. Final plans should be submitted by November 1, 1993, for Council review and approval. The Council will provide for public involvement prior to its decisions. Given the critical status of Snake River salmon runs, the schedule will reflect an expedited time frame for implementation. The Council's determination to approve, reject or amend a plan will be based upon whether the Operations Plan and Design Plan provide for improved survival of Snake River salmon and steelhead to meet biological objectives, and whether implementation would be structurally or economically infeasible, biologically imprudent, or inconsistent with Sections $4(h)(5)-(7)$ of the Northwest Power Act.

(6) FEDERAL PROJECT OPERATORS AND REGULATORS:

a. Implement approved plans in accordance with the schedule adopted by the Council. To ensure prompt implementation of any plans approved by the Council, federal implementing agencies should incorporate the planning process and its results, into ongoing administrative processes, including, but not limited to, National Environmental Policy Act and Endangered Species Act processes.

b. Incorporate the specifications of such approved plans in all system planning and operations performed under the Columbia River Treaty, the Pacific Northwest Coordination Agreement, Congressional 
authorizations and appropriations, all related rule curves, and other applicable procedures affecting river operations and planning; and implement approved reservoir drawdown plans as "firm" requirements.

(7) It is possible that refilling the four lower Snake River reservoirs that have been drawn down to near spillway crest elevation would reduce lower Columbia River navigation channels one or two feet. To address these potential impacts, the Council requests that: a) Congress consider authorizing dredging to maintain a 40 foot navigation channel; b) the Corps begin any necessary National Environmental Policy Act process; and c) the relevant parties time these actions to be consistent with implementation of the lower Snake River drawdown program.

\section{A306 Additional Measures to Increase Survival}

In this section, the Council identifies actions that should begin right away, so that the results can be used by the end of 1993. Included are additional longer-term actions to augment flows, reduce temperatures or otherwise further improve fish survival in the Columbia River Basin. These measures should be in addition to and not displace measures already initiated. Parties conducting tests and evaluations should report progress to the Council no less than semiannually, beginning May 30, 1992, and submit final reports by the end of 1993 . The results will be reviewed by the Council as soon as available to develop the best strategy to meet biological goals and objectives. The object of the process outlined below is to identify and remove impediments to these measures, and expeditiously implement those that achieve biological objectives unless shown to be structurally or economically infeasible, biologically imprudent or inconsistent with Sections $4(h)(5)-(7)$ of the Northwest Power Act.

\section{(a) John Day Drawdown}

CORPS OF ENGINEERS, BONNEVILLE, STATES OF WASHINGTON AND OREGON AND OTHERS:

(1) Identify and report to the Council by March 15, 1992, any measures that can be implemented promptly to remove limiting conditions and allow the John Day reservoir to be operated at a lower level without adversely affecting present users, even if the measures do not achieve minimum operating pool level. For example, if localized dredging around certain irrigation pump intakes would allow the pumps to function effectively at lower reservoir levels and therefore allow the pool to be operated at lower levels, this should be reported to the Council together with an estimate of the time to complete and cost of the dredging.

(2) Beginning immediately, determine requirements, including cost of measures, time to complete, and mitigation of impacts to reservoir users, to permit annual operation of John Day reservoir at minimum operating pool level 
(257 feet elevation) from May 1 to August 31. Report these findings to the Council as soon as feasible and not later than November 1, 1992.

(3) Following Council review of the findings described in paragraph (2), above, and in consultation with user groups along the reservoir, prepare and implement a mitigation plan consisting of measures to mitigate the economic and other impacts of the reservoir drawdown to the extent practicable. Consistent with the mitigation provisions of this amendment (Section A1000), the costs of mitigation impacts should be shared so that local communities, industries, businesses and other entities that depend on the John Day reservoir do not bear a disproportionate share of the burden. The plan should address, but not be limited to:

a. Design, engineering, permitting, equipment and installation costs of relocating irrigation intakes and enlarging pumps as required for irrigators to continue operations adjacent to the reservoir (or providing alternative means of moving irrigation water to application);

b. Devising alternative, higher efficiency means of moving water to applications, including irrigation canals or pipelines from McNary reservoir or other cooperative ventures to exploit economies of scale. To the extent pumping energy efficiencies can be achieved by Bonneville customers, Bonneville should finance and/or purchase such energy savings as a means of offsetting capital costs to users.

c. Impacts of reservoir drawdowns on resident fish, wildlife (particularly threatened or endangered species and existing wildlife refuges), recreationists and the recreation industry, and other environmental values; and

d. Stability of bridges, railways, levees and other structures that may be affected by implementation of the plan.

\section{(b) Additional storage}

BUREAU OF REClamation, CORPS OF ENGINEERS, BONNEVILLE, STATES OF IDAHO AND OREGON AND OTHERS:

Beginning in 1992 and concluding by the end of 1993, conduct a cooperative appraisal study of the potential for new Snake River Basin storage to provide additional water for lower Snake River flow augmentation to aid migrating salmon and steelhead, or to provide added flood control storage that would augment salmon and steelhead flows. Identify and make preliminary evaluation of engineering, hydrologic, economic and environmental aspects of potential sites. In addition, expeditiously explore short-term options to develop storage capacity for 
at least 200,000 acre-feet of water. The Bureau and others should give highest priority to potential new storage opportunities that: a) have highest refill probability; b) are or can be associated with new water supplies made available by the Council-mandated Bureau water conservation projects under this program; c) are located where they provide opportunities to shape flows to benefit fish migration (without intervening barriers); d) are located where they provide opportunities to moderate instream temperatures to benefit fish migration; and e) are not subject to state or other regulation that will preempt stored waters or otherwise substantially impair employment of the projects to benefit fish migration.

\section{(c) Water measures}

Augmenting flows for salmon and steelhead will require a mix of measures, as no single alternative is likely to eliminate the need for all other alternatives. This section puts a high priority on measures such as water banks, water efficiency improvements, water transactions and the like. In calling for these measures, the Council does not intend to alter or affect the water rights or authorities of the states, the Indian tribes, the United States, or any individual. Rather, it seeks to define a role for ratepayers in providing incentives to augment streamflows for salmon and steelhead, and to encourage water management by the states and others that contributes to sustainable salmon and steelhead runs.

STATES OF IDAHO, OREGON, WASHINGTON AND BUREAU OF REClaMation:

Organize a water committee with membership from state, federal, tribal, water user, utility and conservation interests, Bonneville and the Council. With advice and assistance from the committee, recommend options to secure, by the end of 1996, at least one million acre-feet of additional water from the Snake River Basin, and more if possible, to aid spring and summer migrants, using water efficiencies, market mechanisms, water transactions and the like.

Recommendations should include: a) incentive and regulatory programs; b) ways to use existing institutional structures and resolve legal and institutional barriers such as those raised by Idaho water managers to benefit fish flows; c) changes in law, policy and administration to facilitate increases in flows for fish; d) methodologies to determine the cost-effectiveness of various water alternatives;

e) funding sources for such measures; and f) a framework for determining priorities among water alternatives.

By the first semiannual reporting deadline in May 1992, submit a work plan and budget for staff or contractor assistance to accomplish this work and submit recommendations no later than the end of 1993. 
Fund travel and related expenses for committee members and staffing and contractor expenses shown in the work plan and budget approved by the Council.

(3) Bureau of Reclamation, U.S. Geological SuRvey, U.S. Department of AGRICULTURE, AND SOIL CONSERVATION SERVICE:

Evaluate the potential for water conservation, water efficiency or other measures in agency programs with most potential to benefit anadromous fish, and least impact on third parties. Include an evaluation of potential to use crop rotation programs to facilitate dry-year option water leasing activities. Report to the Council and the states' water committee by May 1992.

(4) BONNEVILLE, CORPS OF ENGINEERS AND BUREAU OF RECLAMATION

Under the auspices of the Columbia River Water Management Group, fund a review of the current water supply forecasting system, including:

a. Potential for accuracy improvements of volume forecasts;

b. Potential for forecasting the shape of runoff;

c. Benefits of expanding telemetered snow monitoring system; and

d. Resolution of the institutional barriers for the installation of hydrologic measurement sites in existing and proposed wilderness areas.

Should the review identify methods for improving accuracy or significant benefits elsewhere, Bonneville, the Bureau, the Corps or the states should fund implementation of those methods.

\section{(d) River System Investigations}

BONNEVILLE, CoRPS OF ENGINEERS, AND BuREAU OF REClamation IN CONSULTATION WITH THE COUNCIL AND OTHER INTERESTED PARTIES:

Evaluate seasonal exchanges, long-term nonfirm transactions, options for storing water above power rule curves, accelerated acquisition of winter peaking conservation and renewables, efficient direct application, wholesale and retail price structures, and other changes in power system operations that could increase flows for salmon and steelhead, or offset the cost of improving salmon and steelhead flows. Complete and report to the Council not later than the end of 1993. Include, among alternatives examined in the System Operations Review, a 
full range of system coordination alternatives to facilitate such alternative power system operations. Take steps to include the Idaho Power Company in the coordinated system.

\section{(e) Flood Control Examinations}

CORPS OF ENGINEERS AND OTHERS:

Re-examine all Columbia River Basin flood control strategies and rules to identify modifications, including alternatives to impoundment that could yield more useful or shapeable flows for fish. Include an evaluation of the possible use of space provided when reservoirs are pulled down to minimum operating pool or lower. Submit final report not later than the end of 1993.

\section{(f) Research and Monitoring}

(1) BONNEVILLE:

Fund on an expedited basis evaluations of flow and velocity effectiveness in improving survival of spring, summer and fall chinook and sockeye salmon.

\section{States of Idaho, Montana, Oregon and Washington:}

in coordination with appropriate Indian Tribes: By February 28, 1993, identify specific $\theta$ n an expearch, monitoring and evaluation activities to identify potential impacts of salmon and steelhead flow operations on resident fish and wildlife, particularly native species, in and around Hungry Horse, Libby, Grand Coulee, Brownlee and Dworshak reservoirs.; and Use this information to develop analytical methods orand biological rule curves for reservoir operations, similaratoge to those being developed by the Montana Department of Fish, Wildlife and Parks for Hungry Horse and Libby reservoirs. Include an evaluation of impacts on recreation and the recreational industry.

\section{BONNEVILLE:}

Fund on an expedited basis application of PIT $^{19}$ tags, installation of detectors, and other marking techniques for evaluations.

(Phase 1)4.2 Bonnille-Fund the installation of juvenile PIT tag detection facilities at Little Goose, Lower Monumental, John Day, McNary, and Bonneville dams, to facilitate assessments of naturally producing stocks and improve the quality of monitoring the effects of juvenile and adult fish passage. Coortinate

19 PIT stands for passive integrated transponder. 
with the CBFWA and the Couneil's Monitoring and Evaluation Group-to-develop- $a$ list of proposed priorities and report to the Couneil by September 15, 1991. Following Couneil review and approval of the priorities, implement construetion-of the faeitities. Installation should be in coordination with the Corps of Engineers and the fishery agencies and tribes.

(4) Bonneville: Fund a study of gas supersaturation and its effects on salmon and steelhead passing dams through turbines, collection and bypass systems, spillways, adult ladders and other means, particularly in connection with possible reservoir drawdowns.

(5)h- Fish PASSAge Center, Council AND OTHER PARTIEs: Continue existing monitoring efforts on flows, fish passage, water conditions, smolt condition, etc. 



\section{SECTION A400}

\section{MAINSTEM SCREENS, PREDATION, AND \\ TRANSPORTATION}

\section{A401 Screens}

When mainstem hydroelectric dams originally were constructed in the Northwest, many people believed that providing adequate upstream passage over the dams for adult fish returning to spawn was sufficient to sustain salmon and steelhead runs. Since that time, research has shown that juvenile salmon and steelhead headed downstream also suffer a significant mortality rate as they encounter the dams.

Pressure changes within each turbine are the primary cause of juvenile mortality. The impact of the moving turbine blades and the shearing action of water in the turbine can also cause injuries or death. In addition, juvenile salmon and steelhead may be stunned after passing through the turbines, thus increasing their vulnerability to predators, especially squawfish, which are abundant at the base of each dam. The Council recognizes the need to address all phases of mainstem survival, including installation of juvenile fish screening and bypass systems.

In this section the Council establishes performance standards and sets schedules for the installation of new or improved screens and bypass systems at Snake and Columbia river federal dams. Additionally, the Council calls for continued monitoring and evaluation of existing and new screen designs to continue in an expedited fashion, to improve their effectiveness and ensure the availability of functional screens for anticipated changes in flow/velocity regimes.

\section{(a) Performance Standards}

(1) CORPS OF ENGINEERS:

Install and provide operational fish passage screens and bypass systems at all unscreened federal mainstem dams according to the following schedule:

a. Lower Monumental. Provide operational screening and bypass systems by March 1992.

b. Ice Harbor. Provide operational screening and bypass system by March 1994. 
c. The Dalles. Provide operational screening and bypass system by March 1998.

(2) CORPS OF ENGINEERS AND MID-COLUMBIA PUDS:

Achieve fish passage efficiencies of at least 70 percent and 50 percent for spring and summer migrants, respectively at all Snake River projects that have juvenile fish bypass facilities installed.

(3) CORPS OF ENGINEERS:

Ensure a 98 percent or greater survival rate in all bypass and collection facilities from the deflector screens to the end of the outfall. Where possible, increase survival of smolts in the area below the bypass release points by removing fish predators, protecting migrants from predation by birds, providing alternative release sites or modifying bypass operations.

\section{(b) Measures}

(1) CORPS OF ENGINEERS:

Complete evaluation, design and prototype testing of extended-length fish screens and, if effective, install according to the following schedule. In view of slippage in past schedules, maintain this schedule unless it is wholly impracticable because of Congressional funding limitations or instructions, physical infeasibility, or because the Council determines installation should not occur.

PROJECT

McNary

Lower Granite

Little Goose

John Day

The Dalles

\section{COMPLETION DATE}

March 1995

March 1996

March 1996

March 1998

March 1998

\section{(2) CORPS OF ENGINEERS:}

During design and preparation for installation of fish passage facilities, evaluate and report to the Council concerning modifications that may be needed to accommodate alternative flow/velocity measures outlined below in section 4 . 
Install fish guidance improvements, including lowered submersible traveling screens, streamlined trashracks, and turbine intake extensions at Bonneville Dam Second Powerhouse by March 1993.

(4) CORPS OF ENGINEERS:

Expedite evaluation of fish passage efficiency at Bonneville Dam .. First Powerhouse and report to the Council modifications that may be needed to meet the standards in Section A401(a) above. Expedite rehabilitation of old generating units.

(5) CORPS OF ENGINEERS, BONNEVILLE AND OTHER RELEVANT PARTIES:

Continue to implement fully the 1989 Fish Spill Memorandum of Agreement.

(6) CORPS OF ENGINEERS AND OTHER RELEVANT PARTIES:

Explore promising new approaches to fish bypass technologies, including the use of sound to guide fish. Should results of this research indicate high efficiencies at costs lower than screen modifications, and no persuasive biological or other considerations that would preclude use of a new technique, bring a proposal to the Council for incorporating it into bypass strategies.

(7) CORPS OF ENGINEERS:

Install state-of-the-art juvenile fish size separator and flume at Lower Granite Dam to improve the existing fish collection and bypass system. Complete installation by March 1996.

(8) Federal Energy Regulatory Commission:

Require Douglas County Public Utility District (PUD) to: Ensure that the installed juvenile fish bypass system tailored to the unique features of Wells Dam continues to operate effectively and in accordance with the terms and conditions of the 1990 Wells Settlement Agreement.

(9) Federal Energy Regulatory Commission:

Require Chelan County PUD to:

a. Complete testing and evaluation of a prototype juvenile fish screening and bypass system at Rocky Reach Dam and report the 
results of such tests and evaluation to the Council by August 31, 1993. The evaluation should compare the effectiveness of the prototype screening and bypass system with the best available bypass system. If the Council determines that the tested system is not effective, FERC should require the PUD to evaluate, design and install an alternative collection and bypass system at Rocky Reach Dam such as a surface water downstream passage facility similar to the sluiceways at The Dalles and Ice Harbor dams.

b. Complete installation at Rock Island Dam of a jurenile fish screening and bypass system as set forth in the Rock Island Settlement Agreement.

(10) Federal ENergy Regulatory Commission:

Require Grant County PUD to:

a. Complete testing and evaluation of prototype juvenile fish screening and bypass systems at Wanapum and Priest Rapids dams and report the results of such tests and evaluation to the Council and FERC.

b. Complete installation at Wanapum Dam of a fully operational juvenile fish screening and bypass system by March 1, 1998.

c. Complete installation of a fully operational juvenile fish screening and bypass system at Priest Rapids Dam by March 1 , 1997.

\section{(11) Federal Energy Regulatory Commission:}

Require Chelan County PUD to: Develop plans for spills at Rocky Reach and Rock Island projects by March 1 of each year as set forth in the stipulated agreement for Rocky Reach Dam and the 1986 Settlement Agreement for Rock Island Dam.

\section{(12) Federal ENergy Regulatory Commission:}

Require Grant County PUD to: Provide an increased volume of spill at both Wanapum and Priest Rapids dams to improve fish survival for 80 percent of the spring and summer migrations while avoiding dissolved gas supersaturation problems. The Mid-Columbia Coordinating Committee will have the responsibility to govern the timing and distribution of spill. FERC should require Grant County PUD to implement such a plan for spill each 
year at Wanapum and Priest Rapids dams until juvenile fish screening and bypass systems are installed and operational at each project.

\section{Federal Energy Regulatory Commission:}

Require the mid-Columbia PUDs to: Coordinate and consult with the fish and wildlife agencies and tribes through the coordinating committees (Wells, Rock Island and Mid-Columbia) in design of prototype bypass system studies, as well as the research, evaluation and all other activities required in this section to achieve the most effective permanent solutions to juvenile fish passage problems in the mid-Columbia. By March 20 of each year, the Mid-Columbia PUDs should develop and submit to FERC members of the coordinating committees and the Council an annual fish passage and project operational and maintenance plan. The annual fish passage plan for the midColumbia PUD projects should be coordinated with the various annual implementation plans developed under the auspices of the Fish Operations Executive Committee. At the request of the tribes, fish and wildlife agencies or PUDs, the Council will help resolve any disputes related to achieving the objectives of this plan.

\section{(14) Federal ENergy Regulatory Commission:}

Require the Eugene Water and Electric Board (EWEB) to: Make improvements to the existing juvenile fish screen cleaning and bypass facilities at its Leaburg Canal Hydroelectric Project by December 31, 1992, and to assure that the fish bypass and screen cleaning systems continue to operate effectively. FERC should require EWEB to ensure that the juvenile fish passage efficiency of the Leaburg screen and bypass system is not reduced when EWEB's proposal to raise the elevation of Leaburg Lake is implemented. FERC should require EWEB to assume full responsibility for annual operation and maintenance of these facilities.

\section{(15) Federal Energy Regulatory Commission:}

Require the Eugene Water and Electric Board (EWEB) to: Design and construct a permanent screening and bypass system for juvenile migrants at the Walterville Canal Hydroelectric Project. The juvenile fish bypass facilities should be completed and operational by August 1, 1994. EWEB should assume full responsibility for annual operation and maintenance of these facilities.

\section{A402 Predation}

During the development of the Columbia Basin, modifications have resulted in an environment that favors predators. Conditions beneficial to predatory fish 
include increased spawning habitat, slightly warmer water temperatures, and the introduction of millions of hatchery fish into the system that are diseased and illsuited to escape predation. Other factors that improve predator success include concentrations of smolts at hydro facilities, and the incapacitation of smolts passing through generator turbines. These modifications also have increased predation by birds.

In this section, the Council calls for measures to reduce predation, including a Squawfish Management Program that employs a sport reward fishery. a commercial Indian harvest, and dam angling to remove about 20 percent of the squawfish population. During its implementation, a comprehensive monitoring and evaluation program will evaluate the effectiveness of the program, and measures will be modified if necessary.

\section{(a) Performance Standard}

\section{Bonneville, the CORPS AND the Federal Energy Regulatory Commission:}

Reduce squawfish population by 20 percent in the Snake and Columbia rivers within five years.

(b) Measures

(1) BONNEVILLE AND OTHER RELEVANT PARTIES:

Implement, monitor and evaluate long-term contribution of an expanded squawfish demonstration project. Evaluation should include measures of the change in predator populations and the overall rate of predation. Provide an annual report to the Council on the effectiveness of this program beginning October 1992.

(2) Corps of Engineers, Bonneville and the Federal Energy Regulatory COMMISSION:

Evaluate and expeditiously implement measures to reduce smolt mortality due to fish and avian predation in the design and operation of bypass system release sites including, but not limited to, modifications to existing bypass system outfall structures, modifying project or bypass system operations, or other measures intended to disperse juvenile fish releases below dams.

NATIONAL MaRine Fisheries SeRvice:

Continue to evaluate the extent of interactions between marine mammal and salmon populations. 
Develop a coordinated study plan with the fishery agencies and tribes to evaluate the extent of predation on juvenile salmonid stocks migrating through the five mid-Columbia River reservoirs. By October 1993, all five reservoirs should be indezed for predator populations. The PUD's should prepare a comprehensive report on the extent of predation and predator indezing in the five mid-Columbia River reservoirs by January 1994. The three mid-Columbia coordinating committees should consult with the Council to determine the need for predator control programs. If the midColumbia coordinating committees and the Council jointly determine that predator control programs are warranted, then the PUDs will implement, monitor and evaluate measures to alleviate juvenile salmonid predation in the appropriate reaches of the five mid-Columbia reservoirs beginning in June 1994.

\section{A403 Transportation}

In coordination with the region's fish and wildlife agencies and Indian tribes, the Corps of Engineers operates a large-scale program to collect and transport juvenile salmon and steelhead. This program has been an integral part of the region's fish passage enhancement measures since 1981.

Although considerable research and evaluation have been done on the benefits of transportation, the benefits for some species remain uncertain. Information necessary to properly manage and use transportation is inadequate. Benefits appear to vary widely among species, and may vary between collection points and between years of different inriver passage conditions. Transportation appears to offer appreciable benefits for steelhead and fall chinook (at least in the Columbia), while benefits for spring and summer chinook and sockeye are less clear. However, most scientists who have examined the issue believe that transportation can increase fish survival under some conditions.

Transportation will likely play an important role in the mix of techniques the region will employ to decrease the mortality associated with migration through the hydroelectric system. In particular, transportation offers an alternative to inriver passage when the region's best efforts are insufficient to provide adequate passage conditions. In years of extremely low flow, for example, the survival of fish in the transportation system may significantly exceed that of fish migrating in the river, despite efforts to enhance passage conditions.

The Council believes that the fishery agencies and tribes, through the Fish Transport Oversight Team, are best able to decide when and where to employ smolt transportation. At the same time, it is apparent that additional information is needed regarding when and how transportation benefits fish survival. In 
addition, several innovative ideas for alternative transportation collection systems, techniques and management have been suggested during the amendment process that should be investigated. The region would benefit from a regular infusion of creative ideas for the improvement of transportation management and operations from a broad spectrum of interests. The Council encourages other parties to come forward with creative ideas for transportation. and calls on the transportation operators to take these ideas into full account.

\section{A. Meastures}

\section{(a) Fishery managers:20}

Conduct smolt transportation under conditions where the available scientific evidence indicates that the survival from smolt to adult return to the spawning ground will be greater with transportation than without transportation.

\section{(b) Fishery managers:}

In consultation with other relevant experts, prepare guidelines for present and future management of the smolt transportation program according to Section A403(a), including scientific justification for when and where transportation should be conducted and propose future development of the program. Present the guidelines to the Council by March 1, 1992.

\section{(c) Fishery managers:}

Through the Fish Transportation Oversight Team, prepare annual transport guidelines reflecting Sections A403(a) and (b).

\section{(d) Corps of Engineers:}

Conduct and fund smolt transportation activities at those times and locations specified by the fishery managers using the guidelines developed in Section A403(c).

\section{(e) Corps of Engineers:}

In cooperation with the fishery managers, evaluate techniques for improving transportation for fall chinook, especially in the Snake River. Report to the Council by January 30, 1992, on options available, needed facility modification and research needs. Include in the evaluation the extended use of barges to transport fall chinook even during times of low fish numbers as an alternative to truck transport. Also, evaluate the use of refrigeration or other sources of cool

\footnotetext{
${ }^{20}$ Fishery managers are the fishery agencies and tribal fishery managers.
} 
water, reduced densities, and other stress reduction techniques to improve transport effectiveness, particularly for fall chinook.

\section{(f) Corps of Engineers:}

Continue to improve transportation by upgrading facilities, reducing holding periods to no more than two days, minimizing fish densities, reducing stress in holding areas through shading or other means, and developing smolt release strategies, including dispersing fish in order to minimize predation. Report to the Council by the end of 1993 on the feasibility of increasing transport benefits.

\section{(g) Bonneville, Corps and fishery managers:}

Evaluate the effectiveness of transportation to increase juvenile survival to adult spawning stage under a variety of alternative fish passage conditions and collection points. The Corps should take the lead in coordinating this evaluation. The evaluation should focus on spring, summer, and fall chinook, especially in the Snake River. To the extent possible, include evaluation of the benefits and opportunities of transportation for sockeye salmon as well. Incorporate and coordinate this research with the Fish Passage Development and Evaluation Program whenever possible. The Corps should report to the Council on the outline of a transport evaluation program by March 1, 1992.

\section{(h) Fishery Managers:}

Participate in the evaluation of smolt transportation and provide test fish during all flow years from hatcheries or other appropriate sources. If a suitable source of test fish is not found or if fish cannot be provided for other reasons, report immediately to the Council and suggest alternative evaluations.

\section{(i) Bonneville:}

Fund a preliminary evaluation of: a) the feasibility of constructing and operating alternative fish bypass and collection facilities at the upstream end of Lower Granite reservoir and nearby tributaries for downstream migrating salmon and steelhead; b) an evaluation of the feasibility of constructing an alternative stream channel or pipeline structure adjacent to or in the river to transport smolts to below Bonneville Dam; and c) the feasibility and benefits of net pens to increase survival of transported fish in reducing mortality associated with bypass outfall areas. The evaluation will include preliminary engineering, economic and biological parameters. Report results of the net pen evaluation to the Council by June 30, 1992. Report results of other evaluations by December 31, 1992. 



\section{SECTION A500}

\section{ADULT PASSAGE \\ (for all-eight federat-dans)}

Mainstem Columbia and Snake River hydroelectric projects and some tributary projects present a physical barrier to adult salmon and steelhead migrating from the ocean to spawning areas upstream. To solve this problem, adult fish passage facilities have been constructed at all 13eight mainstem dams on the Snake and Columbia rivers. Water flows and spill guidelines also have been adopted to provide unimpeded passage and maximum attraction of the fish to the fishway entrances.

However, there are still problems at some adult passage of the-Corps facilities that result in delayed passage and mortality. For example, flow and spill conditions intended to assist juvenile migrants at some dams tend to discourage upstream fish migration, mask the flows that attract fish to the fishway, or induce fallback so the fish must relocate and reascend the ladder. They may also increase the level of nitrogen in the water to levels toxic to fish.

In addition, inadequacies in certain mainstem adult passage facilities and in the operation and maintenance of these facilities create passage delays or reduce the success of adult fish passage. Losses and delays of returning adult salmon and steelhead at each dam due to upstream migration problems can be significant and have a cumulative effect. Reducing these passage mortalities could increase significantly the number of adults available for harvest and natural and hatchery production.

The Council has adopted a number of measures to improve adult migrant survival. The Council calls on the Corps of Engineers to implement all spill and operating criteria for mainstem adult fish passage facilities and to make needed improvements. In addition, the Council calls on the Corps to leave juvenile fish screens installed for a longer period to provide protection for adult salmon that fall back through the powerhouse. The Council also recommends additional project biologists to routinely inspect fish passage facilities at mainstem Corps dams. The Council also calls for various evaluations and studies to improve the effectiveness of passage facilities and, ultimately, the survival of adult salmon and steelhead.

\section{A. Measures}

\section{(a) Corps of Engineers:}

Adhere to all existing fishway operating and spill criteria and evaluate needed improvements in criteria jointly with fishery agencies and tribes. 


\section{(b) Corps of Engineers:}

Continue to evaluate all mainstem adult passage facilities, evaluate the need for new facilities, and make facility improvements, as necessary. Provide and install, as necessary, back-up parts, attraction water pumps, or fish turbines at each dam for use in the event of failure of these systems.

\section{(c) Corps of Engineers, Bonneville and fishery managers:}

Evaluate the extent, and identify the causes of interdam adult losses, including non-dam losses, and take action to address these causes, as necessary. Report results to the Council by January 1994.

\section{(d) Corps of Engineers:}

Keep fish screens in place at each dam beyond the juvenile migration where adult fallback is a documented problem, as indicated in the fishway operating criteria developed jointly with the fishery managers and subject to the need for annual screen maintenance.

\section{(e) Corps of Engineers:}

To improve the accuracy of the present adult counting procedures, evaluate the feasibility and benefits of using video-based or other automatic counting and species recognition systems for monitoring adult fish passage at mainstem Columbia and Snake river dams. Report results to the Council by December 1993. If approved by the Council, institute video-based counting of adult fish at appropriate locations.

\section{(f) Corps of Engineers:}

Evaluate the effects of shad population increases on adult salmon passage at mainstem dams. Include in the evaluation the feasibility of selective shad removal in adult ladders. Report results to the Council by November 1994.

\section{(g) Corps of Engineers:}

Continue to upgrade existing adult fish passage facilities, including: a) automation of control systems; b) placement of staff gauges in areas that are accessible for both cleaning and reading; and c) providing velocity meters in areas of known low velocity in the collection channels. 
Provide at least two additional project biologists to inspect both adult and juvenile fish passage facilities at each of the eight federal mainstem dams on a regular basis throughout the fish passage season to ensure all fish facilities are operating according to agreed-upon criteria.

\section{(i) Bonneville:}

Continue with research and development on the feasibility of installing adult fish PIT-tag detectors in the adult fish passage facilities of all mainstem dams, including consideration of capability of removing weak stocks for transport. Report results to the Council by December 1994.

(i) Bonneville and Corps of Engineers, in cooperation with the Idaho Power Company and other interested parties:

Continue to evaluate the biological value of and ability to reduce water temperatures in the four lower Snake River reservoirs during periods of adult fall chinook migration by releasing cool water from both Dworshak Dam and Idaho Power Company's Hells Canyon project during August and September of each year, subject to the guidelines specified in Section A303(b)(1) and (3). The objective of this evaluation is to target reduced water temperatures at Ice Harbor Dam by September 1 of each year, and to determine the effectiveness of these operations on adult fish survival and passage through the lower Snake River. Report results of this evaluation to the Council by December 1993. Policy and technical guidance for determining the magnitude and timing of Snake River temperature control releases from Dworshak and Brownlee should be provided in a July meeting of the Fish Operations Executive Committee. In addition:

(1) Upgrade the COLTEMP water temperature prediction model using the data and knowledge gained from 1991 water temperature control operations and monitoring;

(2) Add to the existing water temperature data monitoring network to collect meteorological and hydrological data that will identify the effect of tributary watershed management and resulting inflow temperatures on mainstem Snake River water temperatures. Include additional water temperature and water velocity measurements in the lower Snake River.

(3) Conduct additional salmon and steelhead migration studies, and coordinate with ongoing fish migration and behavior such as timing, movement, fallback, straying, and other characteristics. Report results to the Council by December 1993. 
Evaluate potential methods for decreasing the water temperature in mainstem fish ladders and apply where appropriate.

\section{(1) Corps of Engineers:}

Evaluate the effects of zero nighttime flow conditions in the lower Snake River on adult passage. Report results to the Council by December 1993.

\section{(m) Mid-Columbia Public Utility Districts (PUDs):}

Evaluate adult fish passage at mid-Columbia PUD projects so that it can be determined if losses are occurring at or between the dams. This study should include adult fish count evaluations and development of a coordinated, comprehensive study plan with the fishery agencies and tribes to evaluate existing adult fish passage at all five mid-Columbia dams and reservoirs. To the extent possible, such evaluations should be coordinated with similar adult fish passage studies being planned by the Corps of Engineers for the federal Columbia River mainstem projects, as well as complementing the terms of existing FERC Wells and Rock Island Settlement Agreements between Douglas and Chelan County PUDs and the fishery agencies and tribes. The PUDs should compile the results of such evaluations into a comprehensive report on adult fish passage at the five mid-Columbia PUD projects and submit it to the Council and members of the three mid-Columbia coordinating committees.

\section{(n) Federal Energy Regulatory Commission:}

Require the Eugene Water and Electric Board (EWEB) to: Design and construct a new right bank fish ladder at Leaburg Dam and a barrier in the Leaburg powerhouse tailrace, or equivalent alternative means, to prevent injury and migration delay of adult anadromous fish such that these adult fish passage facilities are completed and operational by May 15, 1994. FERC should require EWEB to assume full responsibility for annual operation and maintenance of this adult passage facility

\section{(o) Federal Energy Regulatory Commission:}

Require the Eugene Water and Electric Board (EWEB) to: Design and construct a velocity barrier at the Walterville Hydroelectric Project to prevent the migration delay and injury of adult anadromous fish. The velocity barrier shall be completed and operational by April 1, 1994. FERC should require EWEB to assume full responsibility for annual operation and maintenance of this facility. 


\section{(p) (2) Paseat-Starbuck Dam, Tucannon (phase 1)}

\section{Baekground:}

Various habitat problems are being addressed through cooperative efforts in the Tucannon subbasin. There is a need to modify Starbuck dam, however, to allow salmon and steelhead to pass the structure while blocking squawfish from passage.

\section{Meavure:}

1.2(a) Bonneville: Fund (1) placement of structures immediately downstream of Starbuck Dam, to provide sufficient backwater for spring chinook and steelhead to jump the dam during spring runoff; and (2) construction of a structure at the base of the dam to allow fall chinook passage during low flows. 
. 


\section{SECTION A600}

\section{HARVEST}

Because of the critical status of some salmon stocks and the need to realize the benefits of changes in hydrosystem operations, the number of fish harvested must be further limited to allow a sufficient number of adult fish to return to spawn. Those that return, called the escapement, must do so in large enough numbers to rebuild the populations, not just to sustain current low numbers.

Control of harvest, therefore, is a critical component to building a long-term, sustained increase in runs. That simple concept is the only thing that is simple about harvest. Harvest control is complicated by the fact that regulations fall under a number of jurisdictions, there is a mixed-stock fishery, and the demand for salmon to harvest generally exceeds the supply.

Harvest has been shaped by decades of negotiations between the United States and Canada, and by extensive litigation that has involved ocean and inriver fisheries and treaty and non-treaty fisheries.

A 1985 treaty between the United States and Canada provides for international management of stocks that migrate through waters of both nations. The Pacific Salmon Commission makes recommendations to both nations on the conduct of salmon fisheries. The treaty cut back interceptions of salmon returning to Northwest rivers. Stocks of chinook salmon, particularly upper river bright fall chinook from the Columbia River, benefited from the overall cap on chinook harvested in Canadian and Alaskan fisheries. Importantly, the interception of Columbia River salmon by British Columbia is directly related to the interception of salmon of Canadian origin in U.S. fisheries (Alaska and Washington). Further reductions in the Canadian interception of Columbia River stocks may require northern Washington fishermen to reduce their harvest of Fraser River sockeye, for example. Parties to the treaty will meet in 1993 to discuss revisions. This will provide an opportunity to further reduce the interceptions of weak stocks of Columbia River chinook salmon.

The Pacific Fishery Management Council manages salmon fisheries from three to 200 miles off the coast, and state regulations extend to three miles off shore. Since 1980, ocean commercial and recreational fisheries have been constrained in both season length and allowable harvest compared to earlier years. Salmon seasons off Alaska are regulated by the State of Alaska but must be consistent with Pacific Salmon Commission recommendations.

The Columbia River Fish Management Plan, developed as part of the agreement reached under U.S. v. Oregon, established a process that the Columbia River Treaty tribes and state management agencies use to regulate tribal and non- 
tribal fisheries in the river. (The State of Idaho and the Shoshone-Bannock Tribes are not signatories to this agreement.) The plan sets specific goals, timetables and methods for cooperative management of salmon and steelhead stocks, including both natural and hatchery fish production and allocation of harvests.

The Columbia River Compact is the forum used to set the commercial fishing regulations in the river. Congress ratified the agreement between Oregon and Washington for the regulation, preservation and protection of fish in waters over which the states share jurisdiction. (The state of Idaho is not a member of this compact, nor are the Indian tribes.) While the individual states set their own sport fishing regulations in the river, these regulations must complement previous agreements for conservation and allocation for other fisheries.

All the tribal governments involved in salmon and steelhead harvest have regulations to control and manage the harvest in tribal commercial, ceremonial and subsistence fisheries. These regulations are coordinated with state regulations.

In this harvest section, the Council makes no claim to regulatory authority. It clearly recognizes the fishery managers' jurisdiction and tribal treaty rights, and no measure is intended to affect or modify these rights. The Council also acknowledges that there has been substantial progress in harvest management over several decades and that declines in harvest levels have come at considerable economic cost to tribal, coastal and inland communities.

Nevertheless, additional measures are necessary if the region is to meet its long-term goal of biological diversity by rebuilding weak runs and if it is to provide sustainable and adequate harvest levels for tribal, sport and commercial fisheries.

One of the major challenges harvest managers face is that the fisheries in both the ocean and mainstem Columbia River are mostly mixed-stock fisheries. This means they harvest a mixture of hatchery-produced and naturally-produced stocks from many different areas of origin. Because juvenile survival is usually greater in hatcheries, hatchery-produced fish generally can withstand a higher harvest rate than most naturally-produced fish. In some cases, natural production from one area is stronger than natural production from another area (such as the production of fall chinook in the Hanford reach of the Columbia River compared to the Snake River). However, those who fish mixed-stock fisheries are generally unable to harvest specific stocks selectively. Thus, naturally-produced stocks, and weaker (fewer individuals in population) hatchery stocks, are often harvested at rates appropriate for stronger stocks. The result is overfishing of the weaker stocks.

In order to allow harvest of the stronger stocks, some incidental take of weaker stocks is inevitable in most fisheries. The fishery managers use the best available data to estimate the incidental harvest under different fishing regimes. 
Fishing seasons are then set on the basis of acceptable impacts on weaker stocks for which escapement objectives have been established. Stocks of fish without escapement objectives are only protected to the degree that the weakest stock being managed for is protected. This has led to the overharvest of such stocks as Snake River fall chinook and sockeye salmon for which no escapement objectives had been established.

There is also another difficult and related problem. There are more demands for salmon for harvest than there are harvestable fish. The fishing power of commercial fleets is much larger than necessary to take the harvestable surplus of salmon each year. The recreational fishery also has grown over the years and is capable of harvesting large numbers of salmon.

The large demand for salmon to harvest puts a great deal of pressure on the management systems to deliver the maximum number of fish for harvest. Inadequate information and budgets and the variable nature of the salmon, the environment and the fishing fleets, all make it extremely difficult to precisely manage harvest impacts on weak stocks.

In the Columbia River Basin, the problem associated with mixed-stock fisheries results, at least in part, from operation of an increasing number of hatcheries. The mixed stock fishery problem cannot be resolved without implementing a harvest management program that coordinates harvest of production from different areas and also is consistent with both hatchery and natural production. The solution also requires the development and implementation of complementary programs to increase the productivity and survival of natural stocks throughout their life cycle.

It is the Council's belief that combined progress in improved stock identification and in technology that permits selective fisheries has the potential for allowing greater harvest of strong stocks and greater protection of weak ones. Regional fisheries interests are particularly urged to press for additional gains in both areas.

The Council has developed program measures in this section that call for continued consultation and coordination with fishery management entities; harvest management measures to increase spawning escapements; the development of escapement goals and rebuilding schedules; evaluation of methods for reducing impacts on critically depressed stocks by mixed stock fisheries; assessment of benefits from effort reduction; increased law enforcement; development of target and alternative fisheries; development of improved stock identification capability; improvements in harvest data bases; and curtailment of the high seas drift net fisheries.

The Council believes the following measures can and should be implemented through the existing management institutions such as the Pacific 
Salmon Commission, Pacific Fishery Management Council, Columbia River Compact and other existing state and tribal management entities.

The Council also believes that the State of Idaho and the appropriate Columbia River Basin tribes should be included in the Columbia River Compact.

\section{A. Performanee Standart}

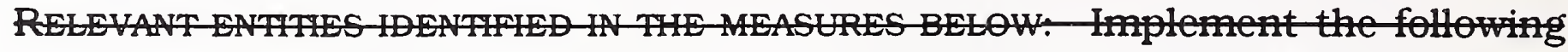
meastres or equivalent to aehieve speeified harvest levels as part of eomprehensive-effert to rebuild weat stoeks. Harvest should be manged to help rebuild the runs and ensure that other benefits to improve-survare "passed through" in the form of inereased spaning eseapements.

\section{AB. Measures}

\section{A601 Goals, Objectives and Rebuilding Schedules}

\section{(a) Management Goals and Escapement Objectives}

FISHERY MANAGERS: Expedite the development and/or re-evaluation of management goals ${ }^{21}$ and spawning escapement objectives ${ }^{22}$ (see Section A200 of this document). Harvest should be managed to meet rebuilding schedules and biological objectives recognizing the statistical quality of the run forecast and the uncertainties associated with escapement objectives. Management goals and escapement objectives for specific production units (evolutionarily significant unit, stock or collection of stocks) will be adopted into the Council's fish and wildlife program in phase three. Failure to establish and manage for spawning escapement objectives could jeopardize Council support for future funding of production and habitat measures in the Council's program.

\section{(b) Rebuilding Schedules}

(1) FISHERY MANAGERS: Develop and/or review and revise as necessary escapement objectives and rebuilding schedules as stated in Section A203. Harvest managers should especially consider how existing harvest

\footnotetext{
21 Management goal specifies the management intent for the stock, and the number of fish needed to fulfill this intent. Management goals also define the population management units which may be evolutionarily significant units, stocks. or collections of stocks.

22 Escapement objective specifies the number of fish. either as a single number or a range. required to spawn to fulfill the biological requirements of the population management unit and achieve the management goal over the long term. Escapement objectives should incorporate the concepts of minimum viable population and effective population size, and accommodate the uncertainty and variability in biological productivity and environmental conditions.
} 
management and legal agreements can be modified to assist with achievement of the rebuilding targets. The development of rebuilding schedules for weak stocks will require the identification and annual achievements of survival targets at a number of stages throughout the life cycle of specific weak stocks. Submit draft biologied-objeetives rebutling sehedutes for-Snatre River spring ant-sumer ehinolk by Mareh 1992. Report progress on the development of biologieat objectives and-rebuilding sehedules for other weat stoeks at that time.

(2) ALL PARTIES: Assist in the development of rebuilding schedules that consider all sources of mortality.

\section{(c) Consultation}

(1) FISHERY MANAGERS: Consult with the Council by the end of February of each year on the consistency of harvest management with the rebuilding schedules and escapement objectives of the fish and wildlife program. The consultation will address:

(1) The extent to which harvest rate escapement objectives and management goals were achieved during the previous year's harvest season;

(2) The extent to which proposed regulations for the coming season are expected to achieve harvest rates, escapement objectives and management goals; and

(3) A status report on management goals, escapement objectives and rebuilding schedules for weak stocks.

\section{A602 Harvest Rates and Regimes}

While there is need to reduce harvest to facilitate rebuilding in the short term, there is also an urgency to move forward with marking programs and to develop selective fishing gear and terminal harvest opportunities that will be available over the long term to fishers to increase harvest while protecting weak stocks of salmon. Fishery managers should look for ways of providing incentives to a) further reduce harvest, and b) accelerate the shift to selective fisheries. This section provides managers with targets, but does not prescribe means to implement. The management agencies should have maximum flexibility to be creative and work with various fishing interests to come up with workable harvest strategies that will meet not only biological objectives but also existing and future Indian treaty requirements and non-treaty allocation, economic and social objectives.

FISHERY MANAGERS: Implement harvest regimes that protect critical broodstocks as part of a comprehensive effort to rebuild specific weak runs. 
Harvest reductions are of particular importance to protect weak stocks that are currently in the ocean. Manage harvest to meet rebuilding schedules, escapement objectives and management objectives, including those established in phase three.

\section{(a) Sockeye}

Manage the fisheries to allow only limited tribal ceremonial and subsistence harvest below the confluence of the Snake and Columbia rivers to facilitate ongoing emergency efforts to rebuild the Snake River population. Commercial fisheries should not be allowed below the confluence until the Snake River sockeye run is rebuilt to a level where the population could support some incidental harvest without jeopardizing rebuilding efforts. The Council also understands that the U.S. V. Oregon parties are committed to rebuilding, and when appropriate, will use the U.S. v. Oregon Management Plan's emergency modification provisions to assist rebuilding. Consult with relevant parties on the potential to target commercial sockeye fisheries in the Columbia River above the confluence of the Snake River, keeping in mind tribal treaty rights.

\section{(b) Fall chinook}

Fishing regulations developed in 1991 by the fishery managers should result in lowering the overall ocean and inriver harvest rate from the 77 percent observed in 1990 to an estimated 63 percent in 1991. In the period 1984-1990, harvest rates were consistently in the range of $70-77$ percent (averaging 74 percent). The Council has adopted biological objectives that propose to limit fisheries affecting Snake River fall chinook in 1992-1995 to a 55 percent harvest rate. The Council strongly urges that this be further reduced below 55 percent, using the measures described below, and calls upon the fishery managers to aggressively implement these actions. The Council will closely monitor the rebuilding of the runs and harvest constraints in order to ensure that the rebuilding schedule in Section II is being met in each cycle and that harvest constraints are contributing their appropriate share to rebuilding.

The Council urges the appropriate state and federal entities in the strongest possible terms to seek substantial and immediate reductions in Canadian harvest rates of Snake River fall chinook through the Pacific Salmon Commission process. Fishery managers will need to work closely with the Pacific Salmon Commission and the Pacific Fishery Management Council to achieve the needed adjustments in ocean harvest rates.

\section{(c) Spring chinook}

The Council recognizes the efforts of the fishery managers and harvesters to reduce the catch of upriver spring chinook beginning in 1976. Continue to manage the Columbia River harvest of spring chinook according to U.S. V. Oregon. Keep impacts of the non-treaty inriver fisheries at about 4 percent of the upriver 
run, the 1987-91 average. Monitor ocean fisheries to ensure that incidental harvest rates remain low, about 2 percent or less of the of the upriver run.

\section{(d) Summer chinook}

The Council recognizes that there have been no commercial target fisheries for summer chinook since 1964 and that the tribal ceremonial and subsistence and non-treaty incidental catches of summer chinook have been fewer than 1,000 and 100 fish each year, respectively, since the mid 1980s. Continue to manage for this level of impact until the populations rebuild sufficiently to allow a higher incidental harvest rate. Subsequently, manage the Columbia River harvest of summer chinook according to U.S. v. Oregon.

\section{(e) Voluntary harvest reduction for all fisheries:}

(1) Design and implement a fish bank program (similar to a farm bank where farmers are paid not to farm) to temporarily reduce harvest by leasing available fishing permits and/or licenses. Reduce harvest level proportionately from that achieved under Sections A602(a)-(d) above. To determine the level of reduction, use historical catch over a specific time or other criteria as the managers deem effective, feasible and fair (for example, use the average documented landings for the previous five-year period). Develop a compensation plan including criteria for qualifying for and continuing in the program. Continue the program through 1995. Review its effectiveness annually with the Council.

BONNEVILLE AND UTILITIES: Fund the planning and implementation of the program upon Council approval.

(2) Implement further harvest reductions below the 1992 level through actions identified below. See Sections A603, A604(a)-(c) and (d), below. These include:

a. Development of a program that will help fishery managers identify weak stocks so that these stocks can be afforded better protection in mixed stock fisheries.

b. Ongoing review and revision of sport fishing regulations in areas where weak stocks are found.

c. More complete accounting of salmon harvest as a by-catch in fisheries for other species.

d. Improved law enforcement to reduce illegal taking of salmon and public education programs concerning the impacts of illegal or wasteful fisheries. 
e. Development of alternative capture technology that will allow unmarked (wild/natural) salmon to be released safely.

f. The development of terminal harvest opportunities in the Columbia River and tributaries to allow the harvest of stronger stocks while minimizing the impacts on weak ones.

(3) Mark all hatchery reared chinook by 1995 to facilitate selective harvest in the future pursuant to findings from the marking feasibility study called for in Section A802(b)(7), below.

\section{A603 Stock Identification}

Develop a program that will help fishery managers identify weak stocks so that these stocks can be afforded better protection in mixed stock fisheries.

\section{(a) Expand genetic stock identification sampling}

FISHERY MANAGERS: Develop and implement an expanded genetic stock identification program for monitoring inriver and ocean fisheries. Review the proposed monitoring program with the Council by March 31, 1992 prior to implementation.

BONNEVILLE AND FISHERY MANAGERS: Cost share expansion of the program to achieve the desired level of additional coverage.

\section{(b) Improve genetic stock identification data base}

FisherY MANAGERS: Determine the need for further development of genetic stock identification data base for Columbia River stocks and evaluate the potential for using DNA fingerprinting and other identification methods to identify chinook, coho, chum, and sockeye salmon and steelhead stocks in the Columbia River Basin. Review findings and recommendations with the Council by June 30, 1992.

BONNEVILLE: Fund the program upon Council approval.

\section{(c) Increase sample rate of harvest}

FISHERY MANAGERS: Review the need for expanded catch sampling programs for ocean and inriver fisheries where Columbia River stocks of concern are caught. Review with the Council by March 1992 the magnitude and cost-effectiveness of any expansion in the existing catch and effort sampling program prior to implementation.

BONNEVILLE AND FISHERY MANAGERS: Cost share expansion of sampling programs to achieve the desired level of additional coverage. 
BONNEVILLE: Fund a project to study the feasibility of developing mass marking methods for salmon that meet the following criteria: 1) the mark should be applied without handling individual fish or causing significant stress; 2) the mark should endure throughout the life cycle of the fish; 3) the mark should be readable without killing the fish bearing the mark; and 4) the methods are inexpensive enough to permit the marking, sampling and processing of a representative sample of recovered marks at a reasonable cost. Conduct this evaluation in conjunction with the evaluation of fin marking of hatchery fish adopted in the Council's phase one amendment process.

\section{A604 Other Harvest Measures}

\section{(a) Review Sport Fishing Regulations}

STATE FISHERY AGENCIES: Re-examine sport fishing regulations, including trout fishing regulations, in weak stock areas and adopt catch-and-release regulations, closures or other measures as needed to protect depressed populations. Review with the Council the need for changes in sport fishing regulations before the 1992 sport angling season.

(b) Accounting for Incidental Harvest of Salmon

PACIFIC FISHERY MANAGEMENT COUNCIL AND NORTH PACIFIC FISHERY MANAGEMENT COUNCIL: Report to the Council on the incidental harvest of Columbia River salmon in other fisheries under their respective jurisdictions. Review with the Council the magnitude of the interceptions and potential for limiting or reducing such interceptions, including the use of guidelines for incidental harvest in those fisheries. Incidental catches should be estimated, and the number of salmon caught applied toward the appropriate salmon harvest quota.

(c) Law Enforcement and Public Education on Impacts of Illegal or Wasteful Fisheries

(1) High seas drift net fisheries

TRIBAL, STATE AND FEDERAL GOVERNMENT AGENCIES, INCLUDING THE DEPARTMENTS OF STATE AND COMMERCE, AS WELL AS OTHER PUBLIC AND PRIVATE PARTIES: Use all available authorities to put a rapid end to all high seas drift net fisheries. The Council urges prompt ratification of the United Nations resolution calling for an immediate, general abandonment of drift netting. 
BONNEVILLE AND THE APPROPRIATE TRIBAL, STATE AND FEDERAL ENFORCEMENT AGENCIES: Develop and implement an expanded enforcement program to provide additional protection to Columbia River salmon and steelhead with an emphasis on weak stocks throughout their life cycle. The program should include an educational component for the public. Fund the needed program, and review accomplishments and scope of the program annually with the Council.

\section{(d) Harvest Alternatives}

BONNEVILLE: Fund the relevant fishery managers to evaluate the feasibility of live-catch fishing technologies and known stock fisheries by 1995 . Include a detailed analysis of alternative incentives to encourage known stock fisheries, including direct subsidies for known stock fisheries in lieu of -- not in addition to - mixed stock harvest in the mainstem Columbia River. Consult with the Council prior to implementation and annually on progress.

\section{(1) Development of alternative capture technology}

This measure develops capture technology to increase harvest of abundant fish stocks and minimize effects on depleted salmon stocks. Pilot projects will be funded to demonstrate the feasibility of various methods to selectively harvest abundant stocks while conserving weak stocks. The study plan should provide for participation by harvesters in the development of new methods and address such questions as public acceptance of the proposed technology, number and location of possible fishing sites, legislative changes needed to apply the proposed technology, and harvester selection for participation in the fishery.

\section{(2) Terminal harvest fisheries in the Columbia River and tributaries}

This measure calls for identification and development of terminal fishing opportunities to harvest abundant stocks while minimizing the incidental harvest of weak stocks.

BONNEVILLE: Fund a study to evaluate potential sites; general requirements to develop those sites (e.g., construction of acclimation/release facilities for hatchery smolts so that adults would return to the general area for harvest); the potential number of harvesters that might be accommodated; type of gear to be used, and other relevant information needed to determine the feasibility and magnitude of the program.

\section{(e) Voluntary Commercial Fishing Permit Buy-back Program}

STATES OF WASHINGTON AND OREgON, BONNEVILLE AND REgIONAL UTILITIES: Develop and fund a voluntary commercial fishing permit buy-back program for non-treaty Columbia River commercial fisheries. The program should be limited 
to two to four years. The goals of the program are generally to: a) reduce fishing capacity on the river; b) respond to dislocations resulting from more restrictive harvest regulation; c) encourage shifting to selective and/or terminal harvest practices employing improved marking and selective harvest technologies as they are identified and become available; and, d) promote sound management, conservation and protection of the resource. The states of Oregon and Washington should retire any permits bought out under this program, and no substitute permits should be issued in their stead.

\section{(f) Inclusion of Idaho on Columbia River Compact}

StATES, CONGRess: Enact legislation to include the state of Idaho in the Columbia River Compact.

\section{(g) Unified reporting of harvest data}

Reporting of commercial and sport salmon harvest, as well as dam passage information and spawning surveys, is scattered among a variety of jurisdictions. This information is needed by the Council, all of the involved agencies and tribes, and the public; all of whom must currently rely on being on the appropriate mailing lists or make a round of phone calls to gather the information each year.

National Marine Fisheries Service: Prepare and circulate a unified, annual report by January 15 on harvest and escapement of various salmon and steellhead stocks in the Columbia Basin. 



\section{SECTION A700}

\section{HABITAT}

\section{A. Biseussion}

Naturally producing populations of salmon and steelhead are generally at sueh-low levels the is the Columbia River Basin. Accordingly, habitat is seeded at low levels. Even so, improvements in habitat quality and quantity are vital to maintaining and rebuilding sustainable populations of salmon and steelhead. in the basin. Habitat provides the basie support for fish, ineltuling the food-rganisms that sustain them.

Salmon and steelhead habitat in the basin has decreased by more than a third, and much of the remaining habitat has been degraded as a result of diverse human activities. An example of habitat change caused by human activities has been documented in the Grande Ronde subbasin. This subbasin produces a natural run of spring chinook that return as adults by early summer and hold in large pools until the fall when spawning begins. These same pools are used by their offspring for rearing from the spring of birth to the next spring when they migrate to the ocean. Significantly, pool habitat has decreased almost $70 \%$ over the last 50 years in the Grande Ronde.

Other indices of the quality of habitat in the Grande Ronde subbasin are also revealing. Water temperatures have increased greatly. Temperatures are high enough during some periods of the year to greatly decrease juvenile growth and sometimes even kill juvenile and adult fish. The amount of cover along the stream has been reduced by over $70 \%$. This affects water temperature as well as the ability of juvenile and adult fish to hide from predators. Finally, cobble embeddedness, which is a measure of the amount of sediments mixed with spawning gravel, ranges from $20 \%$ to $60 \%$. At $20 \%$ embeddedness, about $90 \%$ of the young salmon will survive migrating out of the spawning gravels. At $60 \%$ embeddedness, none of the young salmon will survive. In the Grande Ronde, most areas are at least $40 \%$ embedded.

U.S. Forest Service analysis in other areas of the Columbia Basin indicate conditions similar to the Grande Ronde. In an ongoing project that is comparing 1936-1942 stream survey records to current conditions, the forest service has found that large pool habitat in representative subbasins throughout the Columbia system has decreased 50 to $75 \%$ over the past 50 years. And much of this habitat was already degraded to some extent when the surveys were initially completed 50 years ago. Significantly, the sole 
exception to pool loss has been in wilderness areas where quantity of pool habitat has remained constant or increased. This hat degation signifieantly impairs egg to-smelt suvivat of naturally spawing fish.

Habitat, unlike harvest or some aspects of mainstem passage, cannot be improved or quickly. The impacts of land management activities often last for years, and even decades, after the activities cease. Thus, to rebuild the runs, proper habitat protection and management must begin now.

Many complex and interdependent forces affect habitat. Water quantity, stream temperatures and erosion are examples of factors that individually and collectively affect the health of fish populations and are affected by a myriad of human activities and natural eventsaetities that occur in any specific subbasin. A comprehensive approach is needed forte habitat protection and improvement involving all parties.

In phase one, the Council adopted measures that resulted in selection of leas several model watersheds to demonstrate how intensive efforts to secure a comprehensive and coordinated watershed approach can be achieved. In these watersheds, efforts bill be underway to coordinate the activities of land and water agencies, fisheries managers, land owners, local communities and other affected parties. All potential sources of funding and cooperation be are being identified for use in a comprehensive approach to watershed management.

Phase 1 amendments also included measures aimed at addressing the immediate habitat needs of weak stocks:

- A comprehensive, accelerated program to screen water diversions throughout the Columbia River Basin.

- A series of improvements in federal land management to protect and repair habitat on public lands.

Habitat amendments adopted during phase 2 were intended to set the stage for phase three of the amendment process. One of these measures called for development of criteria for use in prioritization and selection of habitat projects for implementation. A key to these criteria was that highest priority be given to projects in areas of the basin where low or medium habitat productivity or low pre-spawning survival for identified depressed populations are limiting factors. These criteria were also to give priority to projects that were integrated into comprehensive watershed improvement and that promote cooperative agreements with private landowners. These criteria are expected to be incorporated into the program through the phase 3 amendment. In addition, a list of habitat projects that will be 
implemented in fiscal year 1993 will be identified by June 1992 using these criteria.

Other phase 2 amendments addressed the need for development of a streamlined process for funding projects involving private landowners and water rights holders as well as establishment of best management practices under the Clean Water Act for land-use development activities and practices and other human activities. The former measure is important to allow timely access to funding once serious negotiations conclude and projects can proceed. It is anticipated that this process will be submitted to the Council and incorporated into the program during phase 3. The latter measure recognizes the need for guidelines that protect salmon and steelhead from the potentially detrimental effects of human activities. These guidelines are expected to be submitted to the Council by December 1992.

Measures proposed for adoption during phase 3 of the amendment process go much further than incorporating the results of activities called for during the first two phases of the amendment process. The Council recognizes the loss of stocks of salmon and steelhead has occurred, in part, because of continual degradation of the quality and reduction of the quantity of habitat in the Columbia River Basin. This trend continues to affect the abundance and diversity of the stocks that remain. For this reason, dramatic steps must be taken to protect and improve habitat. These steps must be initiated now.

The long-term productivity of naturally producing stocks depends on maintaining and improving habitat quantity and quality. This requires that all activities that affect production of salmon and steelhead must be coordinated. The Council believes that it is possible to protect and improve habitat without undermining the economic uses of all the Columbia Basin's natural resources. The basin's fisheries resource and economic development can co-erist.

Comprehensive watershed management is integral to protecting and rebuilding the remaining stocks in the Columbia River Basin as well as promoting the economic health and stability in the region. The structure and provisions of the Council's habitat section recognize this relationship and also the urgency of implementing projects addressing the habitat needs of Columbia Basin salmon and steelhead stocks.

The habitat section of the phase 3 rule contains three major sections. The first section sets out goals, policies and performance standards. The next section identifies habitat protection and improvement actions. The third section contains program provisions that address comprehensive 
watershed management. Measures from the phase 1 and 2 rules have been incorporated into these sections.

Habitat measures adopted in phases one and wo set the-stage for the third phase of amendment proeedings. At that time, the-Couneil will-eonsider a strueture for comprehensive watershed manement. For that reason, most of the amendment proposals regarding habitat have been-deferred in order not to prejutge or preetude deliberations that will take plaee next year over this important component to the reeveryal maintenanee of Columbia Basin salmon and-steethed-stoeks.

B. Measures

\section{A701 Habitat Goals, Policies and Performance Standards}

\section{(a) Habitat Goals}

All Relevant Parties: The Program has the following objectives for habitat protection and improvement. These objectives should be aggressively pursued in the Columbia River Basin:

(1) At a minimum, maintain the present quantity and productivity of all salmon and steelhead habitat. Next, enhancement activities should assign first priority to improving the productivity of salmon and steellead habitat critical to recovery of depressed stocks consistent with the rebuilding schedules in this program. For actions that improve productivity, priority should be given to actions that maximize increased productivity per dollar spent for habitat improvement.

(2) Ensure human activities that affect production of salmon and steelhead in each subbasin are coordinated on a watershed basis.

(b) Habitat Policies

Relevant Federal, State, and local land and Water Managers and OWNers, Fish and Wildlife agencies, Tribes and all other Relevant Parties:

(1) Develop and implement:

- procedures to ensure compatibility and compliance with the Council's habitat goals, objectives and performance standards

- watershed-specific, measurable performance standards and monitoring procedures to ensure that the Council's habitat 
goals, objectives and performance standards are met "on the ground"

At a minimum, habitat protection should meet national and state standards and regulations.

(2) Improve and maintain coordination of land and water activities to protect and improve the productivity of salmon and steellhead stocks. The Council also encourages local communication and coordination to discuss habitat protection and improvement issues and to resolve problems created by competing missions. The Council encourages private parties to be proactive, to work cooperatively with resource managers, and to improve habitat for the mutual benefit of all involved entities.

(3) Provide elevated or new funding necessary for the successful and timely implementation of the items listed in this section. Funding sources for implementing provisions of the habitat section should include, but not limited to, the U.S. Forest Service, Bureau of Land Management, Bureau of Reclamation, Soil Conservation Service, National Marine Fisheries Service, U.S. Fish and Wildlife Service, Corps of Engineers, Bonneville Power Administration, other relevant federal agencies, all relevant state agencies, local governments, private landowners, resource users and tribes.

(4) Give highest priority to habitat protection and improvement in areas of the Columbia Basin where low or medium habitat productivity or low prespawning survival for identified depressed populations are limiting factors. Give high priority to habitat projects that have been integrated into broader watershed improvement efforts and that promote cooperative agreements with private landowners.

(5) Encourage the involvement of volunteers and educational institutions in cooperative habitat enhancement projects throughout the basin.

(c) Habitat Performance Standards

[The Council is seeking comment on the following two alternatives for habitat performance standards.]

Option A

IDAHO, OREGON, WASHINGTON AND APPROPRIATE FEDERAL AGENCIES:

Submit a plan for meeting the habitat section performance standards on the following schedule: 
- by December 31, 1998 in subbasins where weak stocks are present

- within five years after designation of a subbasin as a model watershed

- by December 31, 2003 in all other subbasins

Ensure compliance with the following performance standards in all applicable waters unless a variance can be biologically justified on a case-by-case basis.

(1) Sediment

a. Limit the percentage of fine sediments $(<6.4 \mathrm{~mm}$ ) in salmon and steelhead redds to no more than $20 \%$ just prior to fry emergence.

b. In subbasins currently limited by sediment problems, ensure no increase in sediment input from implementing or continuing human activities.

(2) Water Temperature

a. Water temperatures should not fall under or exceed the temperature ranges identified for upstream migration, spawning, incubation, or preferred juvenile rearing as specified in the following table.

WATER TEMPERATURE CRITERIA, IN DEGREES FARIRENAIEI, SALMON AND STEELAEAD

\begin{tabular}{|c|c|c|c|c|c|c|}
\hline Species & $\begin{array}{l}\text { Upstream } \\
\text { Migration }\end{array}$ & Spawning & Incubation & $\begin{array}{c}\text { Juvenile } \\
\text { Preferred }\end{array}$ & $\begin{array}{l}\text { Rearing } \\
\text { Optimum }\end{array}$ & $\begin{array}{l}\text { Upper } \\
\text { Lethal }\end{array}$ \\
\hline Chinook & & $42-67$ & 41-58 & $45-58$ & 54 & 77 \\
\hline - Fall & $51-67$ & --- & -.. & -.- & $-\infty$ & --- \\
\hline - Spring & $38-56$ & ... & ... & -.. & -.. & -.- \\
\hline - Summer & $57-68$ & -.- & -.. & -.. & -.. & --- \\
\hline Chum & $47-60$ & 45-55 & $40-56$ & $62-58$ & 56 & 78 \\
\hline Coho & $45-60$ & $40-49$ & $40-56$ & 63-68 & -.- & 78 \\
\hline Steelhead & --- & $39-49$ & --- & $45-58$ & 50 & 75 \\
\hline
\end{tabular}


(a) Provide for long-term recruitment of large woody debris at levels comparable to those observed throughout unmanaged areas.

(b) Preclude the removal of existing large woody debris from stream channels (including non-fish producing waters) to protect the sediment and nutrient storage and processing function of stream ecosystems producing salmon and steelhead.

\section{(4) Large Pools}

(a) Manage for frequency of pools comparable to those observed in unmanaged areas to the extent needed to provide sufficient habitat for salmon and steelhead.

(5) Water Quality Generally

(a) Fully comply with applicable state and federal standards.

\section{Option B}

On an interim basis, the Council calls for compliance with existing state water quality standards, no further increase in sedimentation, and retention of vegetation and shade in perennial and intermittent stream riparian areas within streams supporting salmon and steellhead. Fisheries and habitat managers should develop a comprehensive set of standards taking into account differences in climate, location, conditions and other pertinent factors across the region and submit a list of recommendations to the Council by March 1, 1993. The Council will review and act on these recommendations to provide a final set of performance standards.

\section{A702 Habitat Protection and Improvement Actions}

\section{(a) Land and Water-Management-Aetivities}

(1) Best management practices (phase 1)

STATES OF IDAHO, OREGON, WASHINGTON AND APPROPRIATE INDIAN TRIBES IN CONSULTATION WITH APPROPRIATE WATER QUALITY AGENCIES: Establish best management practices under the Clean Water Act for human activities use development aetivities and praetiees, (i.e. grazing, mining, agrieulture, ete.) to maintain and improve salmon and steelhead production. Best management practices should be designed to meet the Council's habitat goals, policies and performance standards. States should conduct monitoring to assure 
that best management practices are implemented and that instream salmon and steelhead habitat and water quality goals are met. Present practices to the Council by December 31, 1992.

\title{
(2) Federand lanagent aetitities
}

\section{Baeliground:}

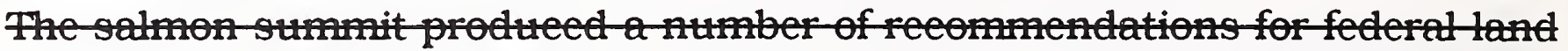
management aetivities, my of which the fecterat land mangers are proeeding to implement. The-Couneil applatuls these-efforts, and adopts the proposed meastres in this proeess. However, the-Couneil atso intends to give full eonsideration to any proposals for additional land management initiatives that may be submitted in the Couneil's amentment proeess that begart Augut 9, 1991 .
\end{abstract}

\section{Measures:}

\section{Livestock Management Plans (phase 1)}

U.S. Forest SERVICE (REgions $1,4,6$ ) AND the BuREAU OF LAND MaNAGEMENT (IDAHO AND OREGON/WASHINGTON STATE OFFICES): Immediately initiate development, updating and implementation of livestock management plans and provide adequate staffing and funding to monitor and supervise all livestock permits in salmon and steelhead production areas consistent with the Council's habitat goals, objectives and performance standards. By December 31, 1992, revise all Iivestock management plans to incorporate and implement the Council's habitat goals, objectives and performance standards, as necessary, and address enhancement of riparian areas and compliance with state water quality standards and best management practices. 23

\section{(3) Exchange, purchase and easements for Protecting Riparian Areas} (phase 1)

Idaho, Oregon, Washington, BUREAU OF LAND MANAGEMENT (IDAHO AND OREGON/WASHINGTON STATE OFFICES) AND U.S. FOREST SERVICE (REGIONS 1, 4, 6): Immediately develop programs to explore and implement land exchanges, purchases or easements in privately owned riparian areas and adjacent lands of a sufficient width to improve and maintain salmon and steelhead

\footnotetext{
${ }^{23}$ Best management practices are a practice or combination of practices that are the most effective and practical (including technological, economic and institutional considerations) means of preventing or reducing the amount of pollution generated by non-point sources to a level compatible with state water quality goals. The development and evolution of best management practices requires the input of experts from each resource that may be impacted in order that all values are be-appropriately considered.
} 
production, with full compensation of landowners. for exehanges of publie lands for high quality riparian lants to premete manngement

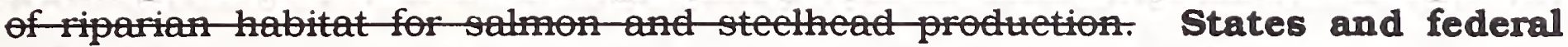
agencies report progress to the Council by December 31, 1991. In addition, federal agencies Pprovide a list to the Council by December 31, 1991 of high quality riparian lands that potentially could be acquired through exchange. (Submission of reports and lists may require further amendment of this measure.)

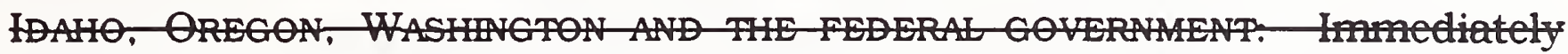
develop programs to explore-and implement land exehanges, purehases or easements in privately owned riparian areas and adjaeent lands of a suffieient width to improve and maintain salmon and steelhead produetion, with fult eompensation of landowners. Report progress to the Couneil by Beember 51, 1991. (phase-1)

\section{(4) Federal Forest Land Management (phase 1)}

U.S. Forest Service (Regions 1, 4, 6) AND BUREAU of LAND Management (IDAHO AND OREGON/WASHINGTON STATE OFFICES): Immediately begin implementing the procedures outlined in the Anadromous Fish Habitat Policy and Implementation Guide and seek means to accelerate the Anadromous Fish Habitat Plan. By September 1, 1992, all land management activities should be designed to at least maintain the quantity and quality of fish habitat. In streams where either water quality standards or federal land management plan objectives for fish habitat and water quality are not being met, initiate actions needed for recovery. Review and, as necessary, amend existing land management plans to incorporate Council program goals, objectives and performance standardsthe Satm stmit gonts for salmon and steelhead. Report to the Council by December 31, 1991 on findings, commitment to making needed changes, and any limitations in resources that could impact the ability to bring land use practices into compliance with the Council's habitat goals, objectives and performance standardsappropriate habers. (Submission of this report may require further amendment of this measure.)

\section{Coordinated Resource Management Practices (phase 1)}

SOIL CONSERVATION SERVICE: Immediately review the potential for increased funding, development and implementation of the coordinated Resource Management Practices process to promote management of state, federal, local and private lands on a watershed basis. Consider participation in model watershed projects (see A703). 3.1, Report to the Council by December 31, 1991, on findings, commitment to meeting this goal, and on any limitations in resources 
that could impact the ability to meet the goal. (Submission of this report may require further amendment of this measure.)

(6) Riparian management

Idaho, Oregon, Washington, Bureau of land Management, U.S. Forest SERVICE AND APPROPRIATE TRIBES: Immediately initiate identification and protection of permanent riparian management areas for all perennial and intermittent streams contributing to salmon and steelhead production. This will include implementation of management options such as:

- where water quality standards are being met, existing shade, vegetation, standing and down large woody debris, and small woody debris will be retained in perennial and intermittent stream channels and riparian areas in salmon and steelhead drainages, whether or not a particular portion of the stream system is fish-bearing;

- where water quality standards are not being met, landowners and managers will initiate action to increase shade, promote revegetation, increase standing and down large woody debris, and increase small woody debris in perennial and intermittent stream channels and riparian areas in salmon and steelhead drainages, whether or not a particular portion of the stream system is fishbearing.

Report to the Basin Oversight Group on progress on this measure by June 30, 1993, and annually thereafter.

(7) Mining

APPROPRIATE STATE AND FEDERAL AGENCIES: Review and, if necessary, seek improvements to mining laws to promote salmon and steelhead productivity. Ensure that all mining activities comply with state water quality standards. Report to the Basin Oversight Group on progress on this measure by June 30, 1993, and annually thereafter.

\section{Conservation easements}

Bonneville AND OTHER Imiplementing Entities: Provide funding for the acquisition and management of permanent conservation easements and of critical water rights for rebuilding and maintaining Columbia Basin salmon and steelhead populations. These acquisitions should be on a willing seller and willing buyer basis. Report to the Basin Oversight Group on progress on this measure by June 30, 1993, and annually thereafter. 
(b) Water Quality and Quantity

(1) Water quality study (phase 2)

Environmental Protection Agency and Relevant Parties: Fund and coordinate a compilation of existing water quality information, determination of additional information needs, and study plan to collect information needed to assess water quality and effects of changes in water quality on Columbia River Basin salmon and steelhead. This study plan will identify areas of water quality that are the highest priorities that should be addressed to aid maintaining and rebuilding salmon and steelhead populations. The project should be a cooperative effort including participation by all relevant entities such as Bonneville, Corps of Engineers, Federal Energy Regulatory Commission, Bureau of Reclamation, fish managers, state water quality agencies, state water resource agencies, Environmental Protection Agency, tribal agencies, land management agencies, U.S. Geological Survey, Council and others. It will be coordinated with the Columbia River Estuary Bi-State Study as well as other appropriate studies and programs. The project will include analysis of point sources, non-point sources, dioxin pollution, transboundary pollution, sewage in metropolitan areas and cumulative effects. Complete compilation and report findings to the Council by May 30, 1992. After approval of the study plan by the Council, Environmental Protection Agency and relevant parties, fund studies to collect information needed to assess causes, effects and means to address water quality impacts on salmon and steelhead. (Amended language will be developed after submission of proposed study plan, currently scheduled for May 30 , 1992.)

\section{Columbia River Estuary Bi-State Study}

IDAho, Montana, OREgon and Washington: Explore expanding scope of the Columbia River Estuary Bi-State Study to include all of the Columbia River Basin.

(3) State Water Quality Standards and Compliance Procedures

IDAHO, OREGON AND WASHINGTON: Review state water quality standards and compliance procedures by June 30, 1992 and report to the Council findings and any limitations in resources to programs that could impact meeting the habitat objectives of the program. If necessary, adjust water quality standards and compliance procedures to meet the program habitat objectives.

(4) Protection from Appropriation of Enhanced Instream Flows 
(b) States of IDAHO, Montana, OREgon AND Washington: Open discussions with the objective of reaching an interstate agreement to protect from appropriation additional Columbia and Snake River basin stream flows that come from storage releases, water conservation or other efficiency improvements, where needed to maintain and rebuildprotet salmon and steelhead populations.

\section{(5) Enhancing Instream Flows for Salmon and Steelhead}

(e) States of IDAHo, Montana, OREgon AND WASHINGTON: To protect salmon and steelhead in the Columbia River and its tributaries, 1) establish instream flow protection levels; 2) enforce-water right permit conditions; 3) deny new water rights if water is not available consistent with salmon and steelhead needs, or if existing water rights or the public interest would be detrimentally affected; and 4) acquire water rights on a voluntary basis by purchase, gift, or through state or federal funding of water conservation or efficiency improvements that produce water savings. Use all available authorities to protect water provided for salmon and steelhead habitat or passage. If existing authorities are inadequate, identify authorities needed and seek legislative approval. In determining whether a proposed diversion or transfer would be consistent with salmon and steelhead needs, consult with fish and wildlife agencies and Indian tribes to determine whether the proposed use would cause any reduction in the quantity or productivity of salmon and steelhead habitat. steetheaputations.

\section{(6) Enforcing Water Rights}

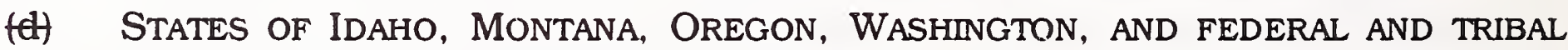
AGENCIES: Improve enforcement of existing water rights and duties for diversions and use from the mainstems of the Columbia and Snake rivers and tributaries. To facilitate these determinations, ensure that existing and new diversions affecting salmon and steelheade streams are equipped with devices to measure instantaneous and seasonal flows.

\section{(7) Water Conservation}

(e) Council: Continue to emphasize water conservation and efficiency improvements to help salmon and steelhead.

\section{(8)(5) Water availability}

Water is a finite resource. The Council is concerned that continuing diversions of Columbia River and tributary water will degrade stream conditions needed by salmon and steelhead. Competing demands for water must be evaluated, and Idaho, Oregon and Washington must consider the cumulative effects of new diversions on water for salmon and steelhead. Elsewhere in this 
document the Council calls for water efficiency, water marketing programs and other means of augmenting flows for fish. Continuing with water diversions that would deprive salmon and steelhead of the benefits of these programs would make little sense.

(a) STATES OF IDAHO, MONTANA, OREGON AND WASHINGTON, BUREAU OF RECLAMATION AND BONNEVILLE, IN COORDINATION WITH APPROPRIATE INDIAN TRIBES, AND OTHER INTERESTED PARTIES: Develop a regional assessment of the availability of water for salmon and steellhead spawning, incubation, emergence and migration in the Columbia River and its tributaries, given current and projected water use and plans to provide secure flows for salmon and steelhead. The assessment should include a range of 50-95 percent probability of water availability. Scope the assessment and submit a plan of work to the Council by May 30, 1992, and submit the assessment by the end of 1993. (Amended language will be developed after May 30, 1992 submission of proposed study plan.)

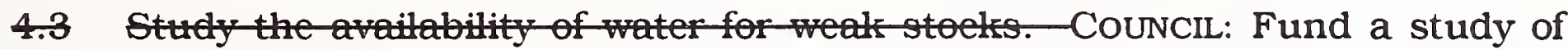
watersheds in which water availability in tributaries is an important limiting factor for weak stocks (phase 1).

(9) Water conservation demonstration projects (phase 1)

\section{Baeliground:}

Salmon and steelhead need adequate river flows for spawning, rearing, and migration. With growing development pressures on streams, there is a need to find innovative ways to leave more water in streams. Many have suggested that more efficient out-of-stream water use may be a fruitful strategy. While there are many questions about how conserved water actually can be secured for salmon and steelhead, the Council agrees that there is a pressing need to answer these questions.

\section{Measures:}

a.1.3(4) BUREAU OF RECLAMATION: In 1991, initiate a cooperative effort with the states of Idaho, Oregon and Washington, and irrigators to select and design at least four demonstration water conservation projects, to provide additional instream flow and enhanced water quality for production of weak stocks. With the states, review the adequacy of existing law and administration to protect enhanced instream flows for fish. Report results to the Council.

b.1.3 BUREAU OF RECLAMATION: Take initiative to secure the necessary funding to: 1) complete watershed selection and planning by the end of 1992, and 2) complete implementation of the demonstration projects by December 31, 1996. 
c.1.3(e) One or more weak stocks should be present in any given subbasin selected for demonstration. There should be at least one demonstration project in Idaho, Oregon and Washington. Consider opportunities to combine one or more of the Water Conservation Demonstration Projects with a Model Watershed Project 3.1, below.

\section{(10) Willamette Subbasin Water Temperature Actions}

- CORPS OF ENGINEERS: Complete investigation of the feasibility of installing devices to control the temperature of the water discharged from Detroit Dam by August 31, 1993. The feasibility study should include an evaluation of nonstructural alternatives such as modification of existing project operating rule curves. The Corps should report study progress to the Council annually and should make recommendations to the Council at the conclusion of the study.

CORPS OF ENGINERRS: Complete its investigation of the feasibility of installing devices to control the temperature of water discharged from Cougar and Blue River dams by August 31, 1993. The feasibility study should include an evaluation of nonstructural alternatives such as modification of existing project operating rule curves. The Corps should report study progress to the Council every six months and should make recommendations to the Council at the conclusion of the study.

\section{(11) Umatilla Subbasin Pumping Project}

BONNEVILLE: Provide power or reimbursement for power costs to Bureau of Reclamation pumping plants designed to exchange Columbia River water for Umatilla River water, so long as the exchange is administered in accordance with federal and state laws, the permit issued pursuant to Application 71293, the transfer order issued pursuant to Application T6621E, and memoranda of agreement resulting from the Contested Case Proceeding on Protested Water Applications 71293 and T6621E.

\section{(c)(1) Water diversion screening-and passage (phase 1)}

Background:

During the last fifty years, state and federal entities initiated irrigation diversion screening programs in several parts of the Columbia River Basin. Hundreds of screens have been installed on important fish-bearing streams. Unfortunately, salmon and steelhead are still being lost in diversions throughout the basin. A large number of diversions .. including many on the Salmon and Grande Ronde Rivers and other streams that support weak stocks .- remain 
unscreened. In addition, many of the existing screening facilities are in need of maintenance or other improvements.

There is an immediate need to accelerate the installation of new facilities on unscreened diversions and repair or upgrade older facilities. Unscreened or poorly screened diversions result in the loss of many juvenile salmon and steelhead that have survived the rigors of natural rearing only to be killed at the beginning of their journey to the ocean. This effort has a high probability of reducing salmon and steelhead mortality and will require the use of all available resources for design, construction, installation and funding. Because of the need for quick action, it is especially important that the resources of the private sector be used to ensure timely construction and installation of high priority screens and measuring devices if such resources are necessary to meet the desired installation timeline.

\section{Meastures:}

(1)1.1(4) FISHERY AGENCIES AND TRIBES: Develop a prioritized list of tributary screening and passage facility improvements for stream diversions in the Columbia River Basin affecting salmon and steelhead. Improvement can include new facilities and the upgrading and maintenance of existing facilities. The listprom should also include Columbia River and Snake River mainstem pump diversions. Priority initially should be given weak stocks, with emphasis on stocks petitioned under the Endangered Species Act in the Snake River Basin. This list will be updated annually through the coordinated implementation, monitoring and evaluation approach (see Section A205). It is essentiat that this proees be completed not later than Deember $15,-1991$, so-that-the-prioritized list ean be usel to implement projeets in 1992.

(2)1.1(b) ALL PARTIES: Criteria for design, construction, operation and maintenance of facilities should be based on standards and criteria developed by the National Marine Fisheries Service (NMFS) in concert with other agencies with expertise in the areas of screening and fish protective facilities in the region-see NMFS, "Fish Sereening Criteria" mertum dated Atrut 21, 1989 and the Nover 16, 1990 - oupplement "Fish Pasage Faeilities Fun tiond-Design Guideline Suplementeriterial). Use the existing expertise of federal, state and tribal entities and others, including the private sector, to accelerate implementation of screening and passage measures. In addition, conduct statistically valid evaluations of screening facilities, as necessary, to assure fish are adequately protected and the number of adult fish returning to the Columbia River, as a result of this program, are assessed. Evaluation will be coordinated through the coordinated implementation, monitoring and evaluation approach (see Section A205). 
(3)1.1(e) BonNeville: Fund the costs associated with the operation of thee Fish Screening Oversight Committee and Technical Work Groups, to established by the National Marine Fisheries Service. These committees will be incorporated into the coordinated implementation, monitoring and evaluation approach (see section A205). The oversight committee will include state, federal (including Bonneville), Council, and tribal representatives and irrigation entities. The committee will provide overall direction, set priorities and ensure oversight of objectives, funding opportunities, standards, biological criteria and evaluation. The Technical Work Groups will include passage experts and other appropriate technical personnel representing federal, state, tribal and irrigation entities. The Yakima Fish Passage Technical Work Groups are to recommend project priorities within their area of concern to the oversight committee and to work with the entity constructing the diversion screens and passage facilities to assure the facilities are constructed according to the prescribed criteria and that the necessary project evaluation is designed and implemented. In the case of large projects, this may include the following:

- $\quad$ Establish written operating criteria
- $\quad$ Develop preliminary designs
- $\quad$ Make certain private landowner and public concerns are addressed
- $\quad$ Review detailed designs to assure biological and engineering criteria
are met
- Monitor construction phases
- Monitor operation and maintenance phases in compliance with
criteria and recommend corrective actions if necessary
- Conduct project evaluations

(4)1.1(4)NMFS, WORKING WITH THE OVERSIGHT COMMITTEE, THE APPROPRIATE TECHNICAL WORK GROUPS, AND BONNEVILLE: I the resources that will be needed to accomplish the screening and passage work and prepare a general operational plan, including a schedule, budget, proposed cost sharing and incentive programs. The plan will also address how ongoing screening and passage programs funded by the Mitchell Act and the states will be integrated a

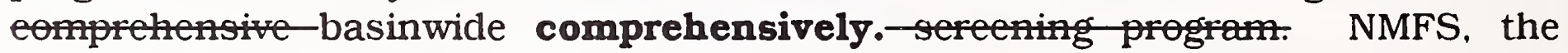
oversight committee, and Bonneville should review this plan with the Council by February 1, 1992. The goal is to complete the installation of all needed screens and passage facilities by the end of 1995. (Submission of this plan may require further amendment of this measure.)

(5)1.1(e) The process outlined above is not intended to interfere with the implementation of screening activities using existing funding mechanisms and programs. Those activities should proceed simultaneously with the process 
outlined above. As the oversight committee and Technical Work Groups processes are developed, the products developed by these groups should be integrated into the ongoing processes as well as the coordinated implementation, monitoring and evaluation approach (see A205).

(6)1.1(4) BUREAU OF LAND MANAGEMENT (IDAHO AND OREGON/WASHINGTON STATE OFFICES), U.S. Forest SERVICE (REgIONS 1, 4, AND 6) AND BUREAU OF REClaMation (PACIFIC NORTHWEST REGION): Require both existing and newin of authorizations, as a condition of the authorization, that diversion structures have functional fish screens and other passage facilities for man-made barriers to salmon and steelhead that meet the criteria referenced above. For existing authorizations, wherever practical, and especially on high-priority diversions, the three agencies should proceed to design and install screens on an agency- or shared-cost basis, with authorization renewals contingent on reimbursement to the agency, or other arrangements satisfactory to the agency. By March 1, 1992 the three federal agencies should report on their progress, including the number of such permits, estimated screening costs, resources needed to implement and monitor the program, and a time frame for compliance. (This report may require further amendment of this measure.)

(7) CORPS OF ENGINeERs: Resume program by January 1993 to inspect all underwater diversions in the mainstem Columbia and Snake rivers to determine whether screens that are effective in preventing losses of juvenile and adult salmon and steelhead are installed and operating. Repair, update and, where necessary, install screens on all diversions by December 31 , 1995. The Corps, National Marine Fisheries Service, diversion owners and other appropriate sources will fund work needed to effectively screen the diversions. Work under this measure should be coordinated with all other measures under this section.

(d) Habitat Project Priorities, Selection Criteria and Espedited Funding Procedure

(1) Project selection criteria

Fisheries Agencies, Tribes, Bonneville and other implementing entities: The habitat criteria identified in Appendix $A$ will be used to prioritize and select habitat projects for inclusion in the annual implementation plan as part of the coordinated implementation, monitoring and evaluation approach (see Section A205). This approach will periodically assess the need for modified criteria.

Bonneville: Convene-and fund a brodt-based-committee-emposed of teehnieal experts to identify salmon and steethead habitat projeet selection eriteria. The eommittee should-inelude-technied-representatives of the fish 
management-entities, land-mangement-entities, water quality and water-resotree managers, Bonnerille, Couneit and others as appropriate. In identifing eriteria. the eom mittee should-eonsider the eriteria identified by the Salmon Summit habitat committee as well as other sourees. Criteria should give-highest priority to projeets in areas of the basin where low or medium habitat produetivity or low pre-spawning survivat for identified-depressed populations are limiting faetors. Also give priority to projeets that have been integrated into broader watershed improvenent projeets and to projeets that promote coperative tandowner timplementor agreements. Oraft eriteria should be eompleted and reported to the-Couneil by Februty $15,1992$.

(2) Identification of Annual Habitat project priorities for Fiseat Yers-1992 and 1993.

a. Section 703 (c)(1) of the 1987 fish and wildlife program will continue to guide the implementation of habitat improvement projects . The date for completion of action item 4.2 under section 1403 is extended through Fiscal Year 1992. (This section may be removed as obsolete during either phase 3 or phase 4 of the amendment process.)

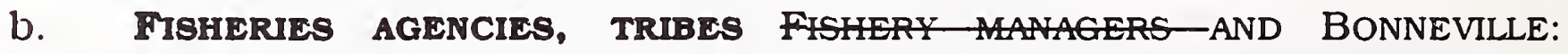
Annually Bdevelop a list of habitat projects from those proposed in the Integrated System Plan, individual subbasin plans, he-model watershed planning efforts and other sources that could be implemented in the upcoming fiscal yearfigeat 1993. Use criteria for selecting projects that arew be identified in Appendix Aseetion a. Give highest priority to habitat improvement projects in areas where low or medium habitat productivity or low pre-spawning survival for identified depressed stocks are limiting factors. Also give priority to projects that have been integrated into broader watershed improvement projects and to projects that promote cooperative landowner/implementor agreements. For Fiscal Year 1993, ecomplete the selection process and present the proposed list to the Council for review by June 15, 1992. Thereafter, complete the selection process as part of the coordinated implementation, monitoring and evaluation approach (see Section A205) and present the proposed list in the draft annual implementation plan.

c. BONNEVILLE AND RELEVANT PARTIES: Upon Council approval, fund the list of habitat projects identified above- 1993.

(3) Streamlined Process for Funding Projects 
Many high priority habitat improvement projects involve transactions with private landowners and water rights holders. In working with the private sector. timely access to funding will be essential once serious negotiations have concluded and parties are ready to proceed. This ability to move quickly is not currently in place, and it is essential to capitalize on agreements to undertake cooperative habitat improvement.

a. BonNeville: In consultation with the fish and wildlife agencies, tribes, Council and other relevant parties, explore alternative procedures for funding high priority habitat projects expeditiously. Report to the Council on a proposed procedure by May 15, 1992. (It is expected that this procedure will be submitted and incorporated into the program during phase 3.)

\section{A703 Comprehensive Watershed Management}

\section{(a) Subbasin Coordinators}

During investigation of habitat issues, the Council was encouraged by the number of federal, state, tribal and local government programs which addressed directly or indirectly habitat protection or improvement. The Council was even more impressed with the number of private initiatives to protect the fisheries habitat in the region.

These efforts include the Soil Conservation Service activities to prevent erosion as typified in the Tuccanon River as well as programs conducted by Trout Unlimited, Long Live the Kings, the Adopt a Stream Foundation and others.

Bonneville: Provide initial funding of a coordinator for a lead agency selected by the respective state to bring together the interested parties and implement the existing programs and efforts. In doing this, it is expected that gaps in and conflicts between programs and efforts will be identified and addressed. This measure should be coordinated with the model watersheds (see Section A703(b)) and the coordinated implementation, monitoring and evaluation approach (see Section A205).

\section{(b) Model Watersheds (phase 1 )}

Coordination of all activities that occur in a subbasin is vital to improving and maintaining production of salmon and steelhead. This coordination ensures that investments in fish habitat improvement will be well spent and successful in achieving the desired result. But the Council's purpose in calling for comprehensive watershed management goes far beyond 
coordination. Implementation of actions should be enhanced and expedited through a process that clearly identifies gaps in programs and knowledge, strives over time to resolve conflict and keys in on priorities for habitat improvement activities. It is also expected that actions will take place in model watersheds, as well as elsewhere in the Columbia River Basin, to address habitat problems that are identified as key limiting factors for salmon and steelhead production.

Bactiground: Acessible habitat for natural produetion in the Columbia Basin has deereased by more than half, and mueh of the remining habitat has been degradectas a resutt of diverse human atities. The anount andity of habitat available to salmon and steelheat are eritieateoneerns in maintaing and restoring poputations.

The Counet reegnizes the-importanee of improting the quatity of the remaining habitat and preventing any net derease in the quanty of habitat, if sustainable inereses in rung of samon and steetheal in the Columbia Basin are to be achieved. There-is already a list of habitat projects in the-fish and-willife program for weat stoeks, and implementing these will require expenditures through 1992. The proposed high priority habitat projects adlress two needs.

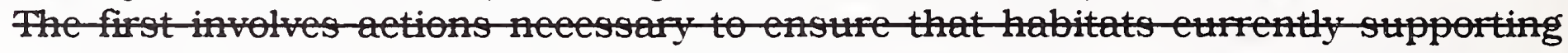
naturat produretion are protected from-futher degradation. The seend is the implementation of aetions aimed at restoring and improving the production potentiat of degrated habitat.

Given the ratue of ownship patterns ander rights in the-Columbia River Basin and the faet that about 40 pereent of the remaining habitat of satmon and-steetheat-stoelss is bordered by private land, comprehensive, eoneerted efforts by both-publie and private-entities are essential for an effeetive habitat magent program.

\section{(1) Hodel tatersheds}

3.1(a) BonnEvLLE. Fund planning for three or more model eomprehensive watershel projects, in luding at least one in Oregon, Itaho, and Washington, to adtress-emprehensively land and water factors that limit-selmon and steethead protuet in tributary, as follows.

(1)3.1(b) IDAHO, OREgon, AND WASHINGTON: Consult with the Council, Bonneville, fishery agencies and tribes, federal and state land and water managers, and local interests in the submission of candidate model watershed projects for salmon and steelhead subbasins. from theughout the Columbia Basin. 
(2)3.1(e) IDAHO, OREGON, AND WASHINGTON: Encourage those who submit candidate projects to employ an integrated watershed planning approach, with the following characteristics and requirements:

An approach plan that involves all the significant interests in a watershed (agencies, private landowners, Indian tribes, community leaders, natural resourcewater users, and othersete). Special effort should be made to include private landowners into the plang process.

- Insofar as possible, incorporate all plans and resolve conflicts among them (e.g. forest plans, subbasin salmon and steelhead production plans, and othersete.).

Cost-sharing and effort-sharing are a major component, involving state, federal, and private parties that can make monetary and other contributions to match Bonneville funds.

Provide for long-term coordination to ensure the approach plan-is fully implemented.

Include a monitoring and evaluation program to assess progress in meeting the plong goals -and long term research needs and opportunities. Monitoring and evaluation development and implementation should be coordinated with the coordinated implementation, monitoring and evaluation approach (see A205). tong-term researeh needs and opportunities should be ass sed in ooperation with the Monitoring and Evaluation Group.

- Provide for the transfer of knowledge about the watershed planning concept, process and results to other groups in other subbasins.

(3)3.1(4) IDAHO, OREGON, AND WASHINGTON: Consider the following elements in reviewing candidate demonstration basins:

- Whether land ownership in the basin is diverse.

- Whether opportunities for cost-sharing and effort-sharing the projects exist.

Whether sufficient interest in water conservation and watershed improvementen by the land owners and managers has been demonstrated, so there is a reasonable expectation that a significant 
proportion of the owners and managers will participate in planning and implementation.

- Whether the Bureau of Reclamation intends to implement a water conservation demonstration project in the subbasin (see Section A702(b)(9).

- Whether there are legal and administrative provisions to protect enhanced instream flows for salmon and steelhead.

- Whether data needed for planning exists or can be obtained relatively quickly for the subbasin.

- Whether there is an opportunity to integrate with ongoing planning activities.

(4)3.1(e) IDAHO, OREGON, AND WASHINGTON: Submit proposed model watershed candidates for salmon and steelhead subbasins to the Council by January 15 of each year.Repe to Couneit 1,1992 on the watershed eandidates-oubmitted.

(5)3.1(f) IDAHO, OREgon, Washington AND BonNEVILle: After Council approval, share in the costs of implementing model watershed projects. Pla should-be eompleted expetitious so that implementation begin in 1992. It is expected that during the first year of implementation the following will be accomplished:

- identify lead entity/entities for each model watershed

- identify all parties with an interest in each model watershed; set up procedures to include all these parties in the development and implementation of the model watershed

- compile all existing plans, programs, policies, laws, and other that relate to comprehensive watershed management in each model watershed

- identify gaps and conflicts in the existing plans, programs, policies, laws, and other that hinder comprehensive watershed management in each model watershed

- set out a path and procedures for filling gaps and addressing conflicts 
- identify key factors limiting salmon and steelhead productivity

- identify list of on-the-ground actions that relate to key limiting factors that could be implemented immediately in coordination with the appropriate subregional group (see Section A205(d)

- provide for the involvement of volunteers and educational institutions in the implementation of projects

During the second year of implementation it is expected that on-theground actions as well as the path and procedures for filling gaps and addressing conflicts would be initiated.

(6) Bonnevilu: Report to the Council at least every six months on progress in each model watershed. 


\section{SECTION A800 \\ PRODUCTION}

\section{Diseussion}

Generally, there are two methods to produce salmon and steelhead. One is through the tre of nturaturat spawning and rearing in streams. The other is by creating artificial spawning and rearing environments, such as hatcheries. Because opportunities to achieve significant production increases through natural production are limited, additional increases may have to be achieved through artificial production. The dilemma is that artificial production can have negative effects on naturally-produced fish. For example, young hatchery-produced fish may compete with naturally-produced juveniles for food and habitat. Or returning hatchery-bred adults may interbreed with wild fish, altering wild gene pools.

The operations of artificial production facilities need to be improved through hatchery operating policies that not only minimize negative impacts of hatcheries on wild and naturally spawning stocks, but improve the quality of the hatchery fish.

One approach to addressing the artificial/natural production dilemma may be supplementation. At its best, supplementation is the enhancement of natural fish populations with hatchery fish that are carefully bred and reared so that they closely resemble naturally-produced fish. This approach may be effective in avoiding the potential harmful effects artificial production can have on naturallyproducing salmon and steelhead populations.

In phase three of this proess, the Couneil intents to eonsider wy to rebuild satmon and steethed populations eonsistent with the goet of maintaining genetie-resourees of salmon and-steelhed in native, naturatized, and artifieidly propagated populations with no avoidable, irreversible losses of genetie diversity resulting from andementing in developing phase three production measures, the Council has identified measures that are consistent with the goal of doubling the number of salmon and steelhead in the basin while maintaining existing levels of biodiversity. This means understanding and documenting the life cycle of wild and naturally spawning fish stopelations at the stream level, so that broader management decisions, while not necessarily made at the stream level, are better informed. It means improving the operations of artificial production facilities, so that impacts of hatchery fish on wild and naturally-spawning stocks are 
minimized and the quality of hatchery fish is improved. This does not preclude well thought-out, scientifically supported programs to supplement naturallyspawning fish populations with hatchery fish. It does mean proceeding with extreme caution to avoid damaging remaining wild and naturally-spawning populations.ste. ${ }^{24}$

\section{A. Performance-Standards}

The Couneil's intent is to develop a plan that will leat to sustained inereases in solmon and steelhea populations at the sume time that it protects and maintains the genetie diversity of the basin's with an natury sparning fish. Speeifiedly, this seetion eontains measturesto.

1. Improve the postease-surivat of hatehery fish.

2. Reduee negative impaets of hatehery releases on will and naturally spaning poputations.

3. Improve long term fitnes and-produtive- streess of hatehery releases interded to naturatly.

4. Ielentify a limited number of high priority supplementation projeets by tan $31,1992$.

\section{B. Meastres}

\section{A801 Genetics, Natural Production and Supplementation}

\section{(a) Genetics and Natural Production}

(1) Council Genetics Team: Complete a proposed plan for conserving genetic diversity within and among Columbia River Basin salmon and steelhead stocks. Report to the Council by December 31, 1991. The framework should provide specific recommendations for how to achieve sustainable increases in salmon and steelhead populations. Specifically, recommend an approach to identifying provisional genetic conservation units for production and harvest and rules for taking action with regard to those conservation units. The team will also assist in the development of performance standards for conserving genetic diversity of natural, supplemented and hatchery stocks.

\footnotetext{
${ }^{24}$ thefinitions.-Native-deseendento of the population present prior to 1850. Nattralizedpopulation of introduced fish that has-sueess fully established a naturally-spaning population. Wild-population that has matained natural produetion with-no intention-supplementation from hateheries. Naturaly-spawing-fish-that spann naturally-las-opposed to artifieially in-a production faeility, regardless of their parentage.
} 
(2) CouncIl Genetics team: Participate in the coordinated implementation process described in Section A205. Develop technical proposals for improved conservation of biodiversity, including identification of genetic conservation refuges, alternative approaches to artificial production, and any other appropriate proposals.

(3) Collection of population status, life history and other data on will and naturally spawning populations

To meet the program goal, baseline information that will improve management and conservation of wild and naturally spawning populations is needed. High-priority populations should be identified immediately so that these can be monitored as soon as possible (see Section A205(b)(2). An extensive initial data collection effort is needed so that interim population units in the basin can be identified. And long-term monitoring strategies need to be developed. The following actions should be coordinated with development of rebuilding schedules called for in Section A203.

a. Interim identification of population units

Bonneville: Fund a project to scope and design an extensive oneor two-year study to identify wild and naturally spawning salmon and steelhead populations in the Columbia River Basin based on genetic, morphological, life history and any other relevant information, and recommend possible indicator populations for monitoring. Consult with the Council's genetics team in designing the project. Bring alternative study designs to the Council by December 31, 1992. Upon Council approval, fund the study.

b. Long-term monitoring

FIsheries agencies aNd tRIBEs: In CONSUltation with National Marine Fisheries Service, the Council genetics team and other APPROPRIATE TECHNICAL EXPERTS: Develop and submit to the Council a proposed program to collect information on wild and naturally spawning populations, including index populations, by June 30, 1993. This should be consistent and coordinated with population monitoring specified as part of the rebuilding schedules in Section A203. The long-term objective of the program is to collect information related to the sustainability of wild and naturally spawning salmon and steelhead populations, including risk containment monitoring of impacts of management action or inaction. The proposed program should include proposals to accomplish the following elements: 
1. Refine the identification of wild and naturally spawning populations provided for above, and develop necessary data bases.

2. Develop a profile on the status of wild and naturally spawning populations.

3. Develop a profile on genetic, life history, and morphological characteristics of wild and naturally spawning populations. Describe the characteristics to be maintained by management actions.

4. Identify limiting factors for wild and naturally spawning populations.

BONNEVLlE: Coordinate with the activities described above and fund a project to scope program costs, duration, feasibility and relative benefits for levels of monitoring ranging from complete monitoring of all wild and naturally spawning salmon and steelhead populations, to monitoring of index populations only. Report to the Council with alternative program approaches by September 30, 1993.

(4) Wild and naturally spawning population policy

To conserve, manage and rebuild the basin's remaining wild and naturally spawning populations, a policy giving such populations explicit priority is needed.

a. Policy development.

Fisheries agencies and Tribes: By December 31, 1992, develop and review with the Council a proposed wild and naturally spawning population conservation policy consistent with the Council's overall program goal and intended to protect genetic diversity, population identity, long-term fitness, and evolutionary capacity. The policy should address habitat restoration, management, and improvement; water use; harvest management; releases of nonnative fish; interactions between resident and anadromous fish; use of wild and naturally spawning populations as broodstock for artificial production; risk assessment, risk containment, and monitoring and evaluation. 
b. Policy implementation

Fisheries Agencies AND TRIBEs: By June 30, 1993, establish with the guidance of the Council's genetics team and appropriate technical experts, and in consultation with land and water managers, a comprehensive wild and naturally spawning population conservation program. Provide for Council and public review. The program should consider for inclusion, but not be limited to, the following:

1. Establishing a management and funding program to address limiting factors.

2. A habitat management and restoration program to maintain and increase the productivity of wild and naturally. spawning populations through the maintenance of their biological characteristics.

3. A management program to maintain the genetic, life history, and morphological characteristics of wild and naturally-spawning populations, including sustainable longterm spawning escapements and redd counts.

4. Maintaining the reproductive isolating mechanisms for wild and naturally-spawning populations.

5. Determining the current and sustainable effective population sizes for wild and naturally-spawning populations.

6. Evaluating and reporting the results of fisheries, land and water management actions annually.

(5) Biodiversity Institute

Scientists and natural resource managers have become increasingly concerned about the need to manage in a way that recognizes the importance of a diverse and productive ecosystem. Biodiversity is the variety of and variability in living organisms, with respect to genetics, life history, behavior, and other fundamental characteristics. It is important at the levels of landscapes, ecosystems, species and populations. There is increasing recognition that conserving biodiversity is key to the sustainability of natural resources, including fish and wildlife. Conserving biodiversity means fostering human development activities that protect the integrity of ecosystems, thereby sustaining natural resources. 
Bonneville: Fund a feasibility study for a Pacific Northwest biodiversity institute. The institute would address native and resident salmonids, their habitats, and ecosystems at stream, watershed, and landscape levels. The purpose of the institute would be to assist in developing research and monitoring programs, provide scientific peer review, provide scientific expertise for regional planning, and conduct research. Upon Council approval, fund project design, including cost sharing.

(b) Supplementation Coordination

(1) BonNEVILLE: Continue to fund the Regional Assessment of Supplementation Project. Fund development of the supplementation master plan called for in A801(b)(6).

(2) Regional Assessment of Supplementation ProJect: Working with the Council's genetics team, provide a framework for implementing and evaluating proposed and ongoing supplementation activities in a coordinated and experimental fashion. This should include provisions for assessing anadromous and resident species interactions in proposed supplementation projects. Complete a basinwide experimental design framework for supplementation by December 31 , 1991. Complete the remainder of the supplementation framework and submit it to the Council for review and approval by September 30, 1992.

(3) FISHERY MANAGERS: Identify and propose a limited number of high priority supplementation activities for initiation on an experimental basis. These should be designed to fill critical information gaps about supplementation. They may include redirecting some existing conventional hatcheries to experimental supplementation. The proposed supplementation activities should be submitted to the Council by January 31, 1992. The Council will then call upon representatives of the Regional Assessment of Supplementation Project, its genetics team and others to evaluate the proposed activities in terms of meeting critical information needs and genetic risks.

(4) Evaluation, design and implementation of proposed additional supplementation experiments.

In response to the Council's phase two amendment, the Columbia River Inter-Tribal Fish Commission (CRITFC) has submitted a list of highpriority supplementation projects. See Appendix D. No other proposed projects have been submitted by other fisheries managers to date. The projects proposed by the commission include provisions for monitoring and evaluation using guidelines developed in Chapter III.C. of the Integrated System Plan. Chapter III.C. also contains guidelines for selecting suitable 
supplementation projects. The Council is encouraging comment on the proposed list of supplementation projects and on the guidelines in the Integrated System Plan. For copies of Chapter III.C. of the Integrated System Plan, request document No. 92-15.

The Regional Assessment of Supplementation Project was created in late 1990 to provide a comprehensive framework for supplementation. The project is being carried out by technical representatives from the fisheries agencies and tribes, utilities, Bonneville, the Council, and others. One of its products will be a recommended planning process. This process will include setting supplementation objectives in terms of post-release survival, reproductive success, long term fitness, and ecological interactions: analyzing benefits and risks; and developing monitoring strategies to contain risk. This planning process is expected to be complete by June 1992, and all RASP products are to be completed by September 30, 1992. For copies of the most recent RASP report, request document 92-14.

FISHeries agencies AND TRIBEs: Use existing processes, including RASP and Chapter III.C. of the Integrated System Plan, to prepare evaluations, including biological risk assessments, for proposed supplementation experiments submitted by CRITFC (and others, if any). Conclude initial review and report to the Council by November 1, 1992. Complete the evaluations by March 31, 1993.

BONNEVILLE: Fund the evaluations, including biological risk assessments, of proposed high priority supplementation projects by the fisheries agencies and tribes. Upon Council approval, fund the implementation of supplementation projects, including staffing, fish transportation, and acclimation and trapping facilities.

(5) Supplementation projects to restore eliminated populations and to recover badly damaged populations with decreasing escapements.

Fisheries agencies and tribes: Provide a technical review of the list of eliminated and badly-damaged salmon populations submitted by the tribes in order to develop a consensus document by September 1, 1992. Develop a phased workplan for evaluating the potential (including assessing biological risks) of supplementing such populations according to Chapter III.C. of the Integrated System Plan and Regional Assessment of Supplementation Project for Council review by December 1, 1992. Begin evaluations by February 1, 1993. Submit evaluations for Council review upon completion. Begin implementation of supplementation projects following Council approval.

Bonneville: Fund the evaluations described above. Use the Implementation Planning Process for determining phased implementation. 
Following Council review, fund the implementation of supplementation projects, including staffing, fish transportation, and acclimation and trapping facilities.

(6) FISHERY MANAGERS: Upon Council approval of the supplementation activities identified above, prepare a master plan and necessary National Environmental Policy Act documents for the group of projects for Council and public review, funded by Bonneville. The master plan should include an assessment of genetic and species interactions risks. This and fllfure supplementation master plans and proposals should be developed in consultation with the Council's genetics team.

(7) HATCHERY OPERATORS NOT FUNDED BY BONNEVILLE: Monitor and evaluate future and ongoing major supplementation activities to answer critical uncertainties identified by the Regional Assessment of Supplementation Project. Upon completion of the Regional Assessment of Supplementation Project basinwide experimental design, analysis of ongoing and planned projects, and survey of critical uncertainties, the Council will call upon the Ad Hoc Technical Team to expeditiously identify monitoring and evaluation needs. Report to the Council on progress implementing this measure by January 15, 1993.

(8) Experimental conversion of existing hatcheries.

a. Fisheries agencies and tribes: By December 31, 1992, develop and propose a policy for experimental conversion of existing hatchery facilities to support programs to conserve and rebuild naturally-reproducing fish populations in the Columbia River Basin, and provide a list of recommended opportunities for such conversion. Provide evaluations of the recommended opportunities using existing processes, including RASP and Chapter III.C. of the Integrated System Plan, by March 31, 1993,

b. Bonneville: Fund a study to identify conventional hatcheries that would be candidates for experimental conversion to supplementation hatcheries for upriver populations. Coordinate with the fisheries agencies and tribes and the Integrated Hatchery Operations Team. Complete the study by March 31 . 1993. 


\section{A802 Hatcheries}

\section{(a) Hatchery Policies, Coordination, and Operations}

(1) Measures to minimize impacts of hatchery fish on wild stocks. [Phase one]

Background: Nearly 100 artificial production facilities produce about 200 million smolts annually in the Columbia River Basin. Approximately 75 percent of Columbia River Basin salmon and steelhead adults are produced in hatcheries. The purpose of these facilities is to mitigate for losses of salmon and steelhead production resulting from dams and other developments. The facilities are operated by different entities, each with its own guidelines for selection, maintenance and spawning of broodstock, mating, rearing, and release of juveniles. Concerns have been raised that hatcheries contribute to the decline of wild stocks through overfishing of wild stocks in mixed-stock fisheries, ecological interactions between hatchery and wild fish, and genetic impacts of hatchery fish on wild stocks. Such concerns were identified in petitions to list certain salmon stocks under the Endangered Species Act. The Salmon Summit proposed that regional consensus be developed on standards and procedures for hatchery operations that are consistent with the goal of rebuilding weak wild and natural stocks. Three entities submitted five proposals to address concerns about the impacts of Columbia River Basin hatcheries on wild stocks, indicating widespread interest. To help develop tools to reduce the impacts of hatchery production on wild and natural stocks, the Council convened a group of nationally-recognized geneticists. These geneticists have been asked to bring the best current scientific knowledge to salmon and steelhead production issues. A number of products have resulted from this effort and are being reviewed at the technical and policy levels in the region.

\section{Meastures:}

a. BonNEVILle: Fund fishery agencies and tribes, and other experts as needed, to develop by December 31,1991 , in consultation with the Council's genetics team (Section A802(a)(1)c, below), basinwide guidelines to minimize genetic and ecological impacts of hatchery fish on wild stocks. In the development of the guidelines, apply the best available scientific knowledge, and include (1) provisions for changing the current management practices, operational goals, and procedures for artificial production facilities to stress protection and recovery of weak stocks, (2) approaches to basinwide coordination of hatchery production to reduce impacts of hatchery stocks on wild fish, and (3) monitoring and evaluation of hatchery and wild stock interactions. Submit a report to the Council for public review in early 1992. 
b. BONNEVILLE: Fund the design of an impact assessment to examine the effects of the Columbia River Basin hatcheries (individually and in the aggregate) on wild fish. The impact assessment would use the best available scientific knowledge and state-of-the-art assessment procedures. Report by December 31, 1991 to the Council when the design is completed.

c. CouncIl: Continue to convene and fund a team of scientific experts that will be available to Bonneville, the Council, and the fishery managers to help scope the hatchery impact assessment and help develop the basinwide hatchery operating guidelines. The team also will be available to consult with Bonneville, the Council, and the fishery managers in the implementation of new artificial production activities, and review ongoing artificial production, in light of the basinwide hatchery operating guidelines. The products and activities of the team will be made available for public review.

\section{(2) Integrated Hatchery Operations Team}

a. FISHERY MANAGERS: By January 15, 1992, create an Integrated Hatchery Operations Team. The team should consist of representatives from Washington Department of Fisheries, Washington Department of Wildlife, Oregon Department of Fish and Wildlife, Idaho Department of Fish and Game, U.S. Fish and Wildlife Service, the tribes, Pacific Northwest Utilities Conference Committee, Bonneville, the Corps, the Council and National Marine Fisheries Service. It should coordinate with production planning activities described in Section A803 below. Duties of the group are described below.

b. BONNEVILLE: Fund the activities of the Integrated Hatchery Operations Team, so that it is operational by January 15, 1992.

\section{(3) Policy development}

a. BONNEVILLE: Fund the development of regionally integrated hatchery policies, building upon guidelines being developed under Section A802(a)(1)a, in the Council's phase one amendments.

b. FISHERIES MANAGERS: Develop regionally integrated policies for management and operation of all existing and proposed hatcheries in the Columbia Basin. These should be consistent with the goal of increasing sustained production while maintaining genetic resources in the Columbia River Basin. Prepare a work plan to develop these 
policies including schedules, time frames, work products, and budget and funding requirements by January 15, 1992.

The policies should include the following elements:

1. Fish health policy: Hatchery practices and operations should preclude the introduction and/or spread of any fish disease within the Columbia Basin, and maximize the health of fish released from hatcheries.

2. Genetic policy: Hatchery facilities and programs should avoid adverse genetic effects on natural and hatchery fish populations and enhance the sustained quality of production from hatcheries.

3. Ecological interactions policy: Hatchery facilities and programs should avoid adverse interactions between natural and hatchery fish populations, including predation, displacement or competition for habitat. They should maximize post-release survival of hatchery fish by increasing similarity of hatchery fish to natural fish, and by balancing the numbers of fish released and release strategies with the capacity of the natural environment.

4. Hatchery performance standards policy: The purpose, goals and objectives of each hatchery should be evaluated in light of the general hatchery policies stated above. Performance standards should be developed for each hatchery, in addition to those provided in this program, including expectations for harvest, maintenance of genetic integrity (including life history, effective population size, morphology, and other important traits), fish health, and ecological interactions. Criteria and plans for monitoring and evaluating achievement of the performance standards should be developed.

5. Regional hatchery coordination policy: Columbia River Basin production facilities should operate under a regional coordination program, including hatchery programs and operations, harvest and research. The objectives of the coordination program should be to facilitate implementation of the regional hatchery policies, incorporate harvest and research considerations in hatchery planning, increase information exchange, coordinate operations to minimize impacts on natural populations, and foster sharing of facilities to increase their effectiveness. 
c. INTEGRATED HATCHERY OPERATIONS TEAM: Develop detailed descriptions for each policy by March 6, 1992. Develop specific and detailed performance standards relating to each of the policies, implementation guidelines, and operating criteria consistent with National Marine Fisheries Service recovery plan criteria by March 1993. Work in consultation with the Council's genetics team (Section A802(a)(1)c, Council phase one amendments) and other experts as appropriate. Incorporate the basinwide guidelines to minimize adverse genetic and ecological impacts of hatchery fish on natural stocks developed under Section A802(a)(1)a, Council phase one amendments. The implementation guidelines, standards and criteria should be scientifically peer-reviewed.

\section{(4) Policy \& Implementation}

a. Fishery MANAGERS: Submit to the Council a plan for implementing the policies by June 1993. Upon Council approval of the plan, fishery agencies and tribes may request Council approval of Bonneville funding for implementing specific parts of the policies.

b. INTEGRATED HATCHERY OPERATIONS TEAM: Prepare a program to monitor compliance with the hatchery performance standards and provide for a coordinated hatchery monitoring program. The monitoring program should incorporate the Augmented Fish Health Monitoring Program. Cooperate with the Coordinated Information System to develop data reporting standards and procedures for all facilities.

\section{(5) Reporting}

a. INTEGRATED HATCHERY OPERATIONS TEAM: Report to the Council annually, beginning in January 1993. Describe new hatchery policies and how operations at existing and planned hatcheries are being changed to implement them and any new information leading to revision of policies and operations. New information should include results of the hatchery impact assessment (Section A802(a)(1)b) Council's phase one amendments), the hatchery survival trends analysis and the carrying capacity evaluation (see research below), when available. Finally, describe the extent of achievement of performance standards, recommend future improvements, and recommend any needed research. The annual report will be made available for review by all relevant parties. 


\section{(b) Hatchery AuditEvaluation and Assessment}

(1) Hatchery Audit. BoNNEVILLE: Beginning in 1992, fund ongoing independent audits of hatchery performance, in consultation with the Integrated Hatchery Operations Team. Such audits should be conducted at least every three years and more frequently as possible and warranted. Include recommendations for improving performance, and for modifying or terminating hatchery programs. Results of the audits should be presented to the Council beginning in July 1993.

(2) BONNEVILLE: Fund a comprehensive analysis of existing data on basinwide trends in hatchery fish survival. The analysis should identify trends over time and by hatchery or geographic area, and correlate hatchery fish survival with natural factors, hatchery operations, and other fish or river management actions. The results of the analysis should be reported to the integrated hatchery operations team by January 1994.

(3) Review of proposed and ezisting artificial production projects.

a. Bonneville: Develop a screening process (specific criteria, a rating system, or a decision tree) for proposed projects. The process would screen out projects that would not meet environmental requirements under National Environmental Policy Act, before undertaking more detailed environmental analyses. The process should consider genetic risks, ecological impacts, cumulative impacts, etc.

b. Bonneville: Work with the Council to develop a procedure for reviewing existing and proposed artificial production projects through a master planning process that is conducted concurrently with National Environmental Policy Act compliance.

(4) Systemwide and cumulative impacts of existing and proposed artificial production projects.

a. BonNeville: Scope a study to evaluate the cumulative and systemwide impacts of existing and proposed artificial production activities on the ecology, genetics, and other important characteristics of Columbia River Basin anadromous and resident salmonids. Coordinate this study with the genetic impact assessment of Columbia River Basin hatcheries called for in Section A802(a)(1)b, above. Report to the Council by December 31, 1992. Upon Council approval, fund the study.

b. Bonneville: Fund a study to develop a method to be used by project proposers and implementors for assessing systemwide 
and cumulative impacts of proposed new artificial production projects. The method should take into account impacts of ongoing artificial production programs as identified above. The method should help meet requirements of the National Environmental Policy Act and the Endangered Species Act. Report to the Council by December 31, 1992.

C. Fisheries agencies aND tribes: In addition to existing methods for evaluating proposed artificial production projects (for example, RASP and Chapter III.C. of the Integrated System Plan), use the method for assessing systemwide and cumulative impacts when available.

(5) Creative partnerships in hatchery production

Bonneville: By June 15, 1993, fund an analysis of opportunities for alternative institutional arrangements and how to implement them. By December 31, 1993, develop and propose a policy to encourage artificial production programs in which alternative institutional arrangements between implementors and managers are used.

(6) Adjust total number of hatchery fish released to carrying capacity

The number of hatchery fish released into the Columbia River has steadily increased since hatchery production began in the late 1800s. Between 170 and 200 million hatchery fish are presently released into the Columbia River Basin system annually. However, the capacity of the Columbia River and its estuary to support young fish has decreased during this time. Some scientists have suggested that the number of fish released may exceed the capacity of the present-day river, estuary and ocean to support their growth and survival to adulthood. Exceeding system carrying capacity may be partly responsible for decreasing survivals of hatchery and wild stocks.

a. FISHeries Agencies AND TRIBEs: Provide an estimate of the current number of hatchery fish released into the Columbia River Basin system. Do not exceed this level of releases until the carrying capacity study is completed (Section A802(b)(6)b). Make recommendations for compensating for releases from new hatchery programs by reducing releases from existing hatcheries, such as those having poor returns. Report to the Council by December 31, 1992.

b. BonNevile: Fund a one-year study to estimate the current carrying capacity of the Columbia River mainstem, tributaries 
and estuary for juvenile fish, using primarily existing data. The study should also make recommendations for management responses to fluctuating estuary and ocean conditions, such as adjusting total numbers of releases to take such conditions into account. Coordinate with the evaluation of mainstem, estuary. near-ocean and marine survival, ecology, carrying capacity and limiting factors called for in Section A804(n). Report the results of the study by December 31, 1993.

(7) Marking hatchery salmon. [Phase one]

Background. The inability to easily identify hatchery fish exacerbates several problems. For example, concerns have been raised that stray hatchery fish may interbreed with wild stocks, or with other hatchery stocks, with detrimental genetic impacts. To protect Snake River fall chinook, which have been proposed for threatened listing under the Endangered Species Act, the Salmon Summit proposed that all fall chinook releases from hatcheries with histories of significant straying be marked. In addition, it is not generally possible to distinguish hatchery salmon from naturally spawning salmon in mixed-stock fisheries. Finally, because not all hatchery salmon are marked, data on migration patterns, contribution to fisheries, and other biological traits which, if known, could be used to improve survival, are limited.

Marking all hatchery salmon has the potential to help solve these problems, making it possible to identify stray hatchery fish and remove them from naturallyspawning populations and from other hatchery broodstocks, to harvest hatchery fish selectively, affording some protection to naturally-spawning stocks, and allowing better data to be gathered on characteristics of hatchery stocks. However, some important concerns need to be addressed. For example, marking fish is believed to decrease their survival, perhaps considerably. In addition, conflicts with use of the fin clip to identify coded-wire tagged fish need to be resolved.

\section{Measures:}

a. FISHERIES AGENCIES AND TRIBES: Identify by December 31, 1991, and report to the Council concerning hatcheries known to have relatively high rates of straying, whose strays are believed to be a threat to the integrity of naturally spawning or hatchery stocks; and identify, if possible, an acceptable mark that complements existing marking programs.

b. BonNeville: Fund the fisheries agencies and tribes to coordinate with technical experts and representatives from the Salmon Summit to determine the feasibility of marking all hatchery salmon, scope the 
marking program, and identify alternative uses for the information obtained. Specifically, the information should provide answers to questions needed to resolve conflicts between hatchery programs and goals for naturally-spawning fish stocks, and improve hatchery fish survival. Report to the Council by February 1, 1992. Coordinate with research to identify methods for mass marking hatchery fish in Section A603(d).

c. BONNEVILLE: Starting in 1992, fund a program to mark all salmon from hatcheries having high stray rates, using the mark determined by fishery management agencies to be acceptable for this purpose, and to evaluate the effectiveness of such marking.

\section{A803 Production Planning}

The Council acknowledges the commitment of the parties to U.S. V. Oregon to use the framework of the Columbia River Fish Management Plan to rebuild upriver runs through production planning and the commitment of the parties to make recommendations for actions by February 1992. The Council further recognizes that Congress has instructed the United States Fish and Wildlife Service and the National Marine Fisheries Service to prepare plans and implement pilot programs designed to assist in the rebuilding of fish runs above Bonneville Dam and to report to Congress on such activities within 120 days of enactment of those agencies' appropriations acts. To coordinate with the foregoing measures, the Council calls on the fisheries managers to:

(a) Take the products of the Regional Assessment of Supplementation Project and the Council's genetics team into consideration in production planning;

(b) Obtain review of production plans by appropriate scientific experts in light of the frameworks provided by the Regional Assessment of Supplementation Project and the Council's genetics team;

(c) Coordinate with the Integrated Hatchery Operations Team in production planning; and

(d) Brief the Council on progress monthly, beginning in December 1991, and complete products by June 15, 1992. 


\section{A804 Other Production Measures6. Researeh}

\section{(a) Captive broodstocks}

Captive broodstock programs have the potential to rapidly increase adult numbers, while retaining genetic diversity of severely depleted wild or naturallyspawning stocks of salmon. The captive broodstock concept differs from that used in conventional hatcheries in that fish of wild origin are maintained for a single generation in captivity. Their offspring are released to supplement wild populations.

Implementation of captive broodstock programs may be the most effective means of accelerating recovery of severely depleted stocks. High survival from egg to adult and maintenance in captivity for no more than a single generation should assure that genetic integrity and adaptability to native habitats are preserved. Even in a situation where barriers to survival were relaxed to the point that the population could double each generation, it is projected to take more than nine generations for a run to rebuild to the same number of spawners as could be provided by a captive broodstock program in one generation. Furthermore, stable egg supplies provided by a captive broodstock program should act a catalyst for habitat restoration and help ensure stock recovery.

Researchers have been developing basic captive broodstock methodology for a number of years. Nevertheless, considerable technical information is required prior to production scale implementation of large-scale captive broodstock programs.

BONNEVILLE: Fund development of captive broodstock technology and implementation of captive broodstock programs to aid in recovery of severely depleted stocks of salmonids in the Columbia River Basin. Programs should be consistent with the products and conclusions of the genetics and natural production framework provided for elsewhere in this section. Critical investigations that need to be funded concurrently include: 1) review of the state of the art of captive broodstock management technology; 2) development of genetically sound methods of sourcing and breeding broodstock to ensure genetic stability and gamete quality; 3) modeling of genetic consequences of captive broodstock programs; 4) development of captive broodstock culture systems that minimize loss of fish: 5) development and testing of a model broodstock program; 6) evaluation and comparison of fish husbandry techniques; 7) evaluation of fish health problems; 8) investigation of somatic and reproductive physiology; and 9) evaluation of fitness of captive brood progeny for supplementation. 

(Grande Ronde Subbasin).[Phase One]

Baekground:-The Minam and Wenaha rivers, in the Grande Ronde River Basin, have been designated by the State of Oregon as genetic sanctuaries for wild endemic spring chinook salmon. Stray hatchery fish of non-local origin have been observed in the Minam and Wenaha basins in recent years. There is an immediate need to eliminate hatchery strays from entering these genetic sanctuaries.

Starting with the 1990 brood, hatchery operators have marked all hatchery chinook in the Grande Ronde River Basin for identification. Trapping facilities on the lower reaches of the Minam and Wenaha rivers are needed so that all fish entering these genetic sanctuaries can be trapped and examined, hatchery fish can be removed, and natural escapement levels and population productivity of these rivers can be determined.

\section{Measures}

Z.2(a)BONNEVILLE: Fund planning, design, construction and operation of spring chinook trapping facilities on the lower reaches of the Minam and Wenaha rivers.

(c) Portable adult collection/holding and juvenile acclimation/release systems. [Phase 1]

Baekground: As weak stocks or populations of salmon and steelhead are identified and assessed, supplementation will be one option to consider to help rebuild these stocks. Decentralized facilities to permit the capture and holding of brood stocks and facilities to acclimate the juvenile fish before release could be useful in this effort. The use of local brood stocks is fundamental to maintaining genetic diversity. The use of acclimation and release facilities to rest and imprint the juvenile fish prior to release is important to increase their survival and ability to imprint on the release stream, and thereby reduce to natural levels their straying into other watersheds. The portability of these facilities should allow them to be used flexibly.

\section{Meatureg:}

(1)2.3(a) BonNeville: Fund the planning, design, construction and operation of a demonstration project for the development of portable adult collection and holding facilities and juvenile acclimation/release facilities. The project should build on the earlier work funded by Bonneville (see Compendium of Low-Cost Pacific Salmon and Steelhead Trout Facilities and Practices in the Pacific Northwest, September 1984) and other relevant information and experience. The project should be initiated in 1991 and facilities in place in 1992. 
(2)2.3(b) The demonstration project should involve only existing hatchery programs or fish populations that are currently being supplemented.

(d) Ringold Hatchery Site Enhancement and Water Development [Phase one]

Baekground:The Washington Departments of Fisheries and Wildlife currently have water rights for 100 cubic feet per second (cfs) of water from springs located adjacent to the Ringold Hatchery site. Of this amount, the agencies are only able to capture and use about $36 \mathrm{cfs}$. The agencies cannot make the full right permanent unless the facilities for capturing, transporting and using the water are improved. These rights have a permit status, which means the state has the legal right to take water but a certificate of appropriation is not issued until the water is actually being used. The temporary permit will be revoked and the water right lost in 1991 if action is not initiated to use the water.

\section{Measures:}

(1) BONNEVILLE: Insofar as needed to secure a $100 \mathrm{cfs}$ water right for the Ringold hatchery facility, fund planning, design and construction of the necessary facilities to capture up to $100 \mathrm{cfs}$ of water and deliver it to the area of the hatchery site.

(2) BonNEVILLE: Fund planning, design and construction of the facilities determined to be necessary to improve existing production. Report to the Council for approval before proceeding with construction.

\section{(e) Supplementation of Snake River fall chinook}

(1) Fisheries agencies aNd TRIBes: In consultation with NMFS, use Regional Assessment of Supplementation Project process and develop experimental design for implementing, monitoring and evaluating supplementation of Snake River fall chinook. Submit to Council for approval by March 31, 1993.

(2) BonNeville: Upon approval by the Council in consultation with NMFS, implement supplementation experimental design developed by the fisheries agencies and tribes.

(f) Reintroduction of Anadromous Fish in the Upper Cowlitz River Basin

In 1991, Bonneville entered into an agreement with Public Utility District No. 1 of Lewis County to purchase the electricity output from the Cowlitz Falls Project. The Project is located above Mayfield and Mossyrock Dams on the Covilitz River which currently block anadromous fish passage 
into the Upper Cowlitz Basin. A settlement agreement for Bonneville's acquisition of the Project output requires Bonneville to fund smolt collection facilities at Cowlitz Falls for use in a trap-and-haul fishery above Mossyrock Dam. Bonneville is coordinating a technical advisory group, composed of state and federal fish agencies, Tacoma and Lewis County utilities, and environmental groups, to establish objectives for the reintroduction of anadromous fish in the upper Cowlitz. The members of the working group are guiding development of project plans and their implementation. The Council notes with approval the cooperative effort to plan reintroduction of anadromous fish in the Upper Cowlitz and the agreement on production objectives. The Cowncil expects these agreed upon objectives to be incorporated within the system planning process for the Cowlitz subbasin.

\section{(g) Pacific Lamprey}

Pacific lamprey eels are anadromous fish historically present in the Columbia and Snake Rivers. Lamprey are a traditional food source for Columbia Basin Indians and remain culturally important. The Council has not previously called for measures to address lamprey populations. The tribes have noted that lamprey populations appear to be declining.

BONNEVILLE: Fund a unified data collection and analysis project to provide a status report to the Council on Pacific lamprey populations in the Columbia and Snake Rivers by December 31, 1993.

\section{(h) Lower Columbia River Coho Salmon}

Natural production of coho salmon in the Lower Columbia River has declined to extremely low levels. Less than 25,000 spawn naturally in scattered tributaries of the lower river. In 1990 a petition was filed with the National Marine Fisheries Service for protection of the population under the Endangered Species Act of 1973. On June 7, 1991, NMFS declined to list the population after its review of available data failed to identify a population segment in the lower Columbia River genetically distinct from coastal populations, but expressed a willingness to evaluate further data.

Naturally producing coho represent an important resource in the lower Columbia River that can be protected and rebuilt. The importance of doing so includes maintaining genetic diversity, reducing the almost exclusive dependence on hatchery production and preserving recovery opportunities.

(1) OREGON AND WASHINGTON: Identify naturally producing populations of lower river coho and adopt management goals to rebuild those populations to self-sustaining levels. 
(2) OREgon AND WAshington: Continue research to determine genetic distinctions between lower river coho and coastal populations. Submit products of the research to the National Marine Fisheries Service.

(3) OREGON AND WASHINGTON: Incorporate recommendations of the Regional Assessment of Supplementation Project and the Council's genetics team in developing management directions.

(4) Bonneville, Fisheries agencies, and tRIBEs: Survey subbasin plans submitted for the Integrated System Plan for limiting factors identified for naturally producing coho populations.

(5) BonNeville, Fisheries AGencies, AND TRIBEs: Fund a survey of land management regulations affecting coho habitat. Include reviews of state forest practices regulations and federal land management plans affecting coho habitat. Develop recommendations for revisions to support rebuilding objectives.

(6) BONNEVILLE, FISHERIES AGencies, AND TRIBES: Fund a review of current production and harvest management practices for impacts on naturally producing coho populations including competition from release of juveniles, disease and predation. Solicit recommendations for revisions of management practices to support rebuilding efforts.

\section{(i)_Columbia River Chum Salmon}

Chum salmon are listed in the Integrated System Plan as a stock of high concern. Counts on the spawning grounds have dropped from over 700 per mile in the early 1950 s to a low of less than 100 per mile in recent times. Catches of this species exceeded 700,000 per year in the 1920s, but catches have exceeded 2,000 fish only twice since 1960 . The last few years counts have been up slightly, but abundance continues to be low compared to historic counts.

Chum once spawned in many tributaries of the Columbia Basin, including some above Bonneville Dam. They are now found only in the Grays, Elochoman and Lewis subbasins. Habitat degradation, passage barriers and harvest have all contributed to reductions in this species.

(1) OREgON AND WASHINGTON: Identify naturally producing populations of chum salmon and adopt management goals to rebuild those populations to self-sustaining levels. 
(2) OREGON AND WASHINGTON: Incorporate recommendations of the Regional Assessment of Supplementation Project and the Council's genetics team in developing management directions.

(3) BONNEVILLe, FISHeRIES AGenCIES, AND TRIBES: Survey subbasin plans submitted for the Integrated System Plan for limiting factors identified for naturally producing chum salmon populations.

(4) BonNeVille, Fisheries agencies, and TRIBEs: Fund a survey of land management regulations affecting chum salmon habitat. Include reviews of state forest practices regulations and federal land management plans affecting chum salmon habitat. Develop recommendations for revisions to support rebuilding objectives.

(5) BONNEVILLE, FISHERIES AGENCIES, AND TRIBES: Fund a review of current production and harvest management practices for impacts on naturally producing chum salmon populations. Solicit recommendations for revisions of management practices to support rebuilding efforts.

\section{(i) Columbia River Sea-Run Cutthroat Trout}

Sea-run cutthroat trout are found in all tributaries below and several tributaries above Bonneville Dam. No good measure of run strength exists. Likewise, little is known about early life history survival, ocean survival, catch, or escapement of Columbia Basin sea-run cutthroat trout populations. It is known that these populations are depressed. Experts believe that habitat degradation and interactions with hatchery salmon and steelhead have caused this depression. Regardless, sport angling for sea-run cutthroat trout is an important fishery and much support for rebuilding these populations is evident.

(1) OREGON AND WASHINGTON: Identify naturally producing populations of sea-run cutthroat trout and adopt management goals to rebuild those populations to self-sustaining levels.

(2) OREGON AND WASHINGTON: Incorporate recommendations of the Regional Assessment of Supplementation Project and the Council's genetics team in developing management directions.

(3) BONNEVILLe, FISHeRIES AGENCIES, AND TRIBES: Survey subbasin plans submitted for the Integrated System Plan for limiting factors identified for naturally producing sea-run cutthroat trout populations.

(4) BONNEville, Fisheries agencies, and tribes: Fund a survey of land management regulations affecting sea-run cutthroat trout habitat. Include 
reviews of state forest practices regulations and federal land management plans affecting sea-run cutthroat trout habitat. Develop recommendations for revisions to support rebuilding objectives.

(5) BonNeVILle, Fisheries agencies, aNd tRIBEs: Fund a review of current production and harvest management practices for impacts on naturally producing sea-run cutthroat trout populations. Solicit recommendations for revisions of management practices to support rebuilding efforts.

(k1) SnatkeColumbia River Sockeye Salmonrebuitding (Phase 1)

Baeleume-In the summer of 1991, the Shoshone-Bannock Tribes, the Idaho Department of Fish and Game, the Bonneville Power Administration, and others initiated an emergency program to conserve Snake River sockeye. The Council endorses this effort, but regards this program as a highly experimental measure that should be implemented with appropriate safeguards.

\section{Measureg:}

(1) Bonneville: Fund the program of the Shoshone-Bannock Tribes, and the Idaho Department of Fish and Game to protect and rebuild Snake River sockeye with the following features:

- Divide smolts captured for rearing in this program among two or more lots; each lot with a separate water supply, alarm systems, and other protective measures.

- A panel of genetics experts should provide advice throughout the recovery effort. This panel should address aspects such as rearing and mating techniques, research protocols and monitoring needs.

- Provide an annual review of the practices and performance of the program for review by the National Marine Fisheries Service and the Council.

- Recognize the experimental nature of these emergency actions, and incorporate monitoring and evaluation measures to learn from implementation.

(2) BonNEvilLE: Regularly update the governors of the Northwest states, the Northwest congressional delegation, the Council, and other concerned parties on the progress of this project.

(3) Bonneville, Fisheries agencies and Tribes: Fund and develop for Council review a plan for reintroduction of sockeye salmon into appropriate 
production areas. This plan should consider reintroduction in all historical production areas. This plan should also consider creating anadromous populations by managing kokanee, such as those found in Pelton reservoir, in a manner that allows access to the ocean. This measure should be coordinated with the Regional Assessment of Supplementation Project, Council genetics team and coordinated implementation, monitoring and evaluation approach.

\section{(1) Cryopreservation}

(1) Cryopreservation (preservation of fish gametes by freezing) has the potential of allowing "banking" of genetic stocks for future use, especially when the population is severely depleted and its habitat has been damaged or destroyed.

(2) BonneVILle: By December 31, 1992, fund research to improve cryopreservation technology and develop applications for helping to restore and preserve depleted populations.

(m) Evaluation of Survival, Ecology, Carrying Capacity and Limiting Factors

BONNEVILLE: Fund an evaluation of mainstem (including reservoirs), estuary, near-ocean, and marine survival, ecology, carrying capacity and limiting factors. Include competition between shad and anadromous salmonids. The evaluation should include analysis of existing data, identification of critical uncertainties and research needs. Also fund development of a study plan which should be coordinated with measures in Section A802(b)(6)b and presented to the Council by January 1993. Upon approval by the Council, Bonneville and/or other parties identified by the Council should fund the proposed study. 


\section{SECTION A900}

\section{INFORMATION MANAGEMENT}

\section{FRAMEWORK DEVELOPMENT, REGEARGH ANDM MONITORING}

Solutions to the problems faeing satmen and steelhead produetion will involve a diverge range- of aetions. For many of these, the-degree of biologied effeet will be uneertain. Nonetheles, aetion is elearly needed, and wating for tefinitive answers is a luw the region eannot afforet.

For this reason, the-Couneil-reming eomitted to the eoneept of ataptive mangement. This ealls for bold aetion in the faee-of uneertain. Aetions will be taken to elarify uneertainties and guide future actions. This approneh does not justify ill-eneeived aetions beeatse of some unspeeified learning that might oeeur. Qutrite the eontrary, ataptive mangement ealls for considered implementation of aetions in a manner that willilluminate-ineffeetive-alternatives and reved a eourse that will achieve the Couneil's goals. The program framework (Seetion -II), ineluding the rebuttling sehedule and-biologieal objectives, is the vehiele for identifying a set of aetions that are most likely to aehieve the goats given the present knowledge regarding the fisheries resouree.

A trey eomponent will be a proedure to effeetively plan aetions to meet information neds and traek progress toward the goals and rebuilding sehedules The-Couneit has reect a number of eomments ealling for measuring progress and traeling aetions funded under this program. When fully developed, the program framewort will provide biologieatobjeetives and meastrable performanee standards to trael progress. Other eomponents of the monitoring and evatuation proess inetude the coordinated information system, a cordinated annut researeh and monitoring plan, and measures to promote the eollection, eordination, and dissemination of researeh and monitoring data. In this amendment ele, the Couneil will adtress only the development of the program framework. A more complete set of actions to athless these needs will be eonsidered during phase three of the amendment proess.

\section{A. Meastures}

\section{Ad-Hoe Poliey and Teehnieat Teams}

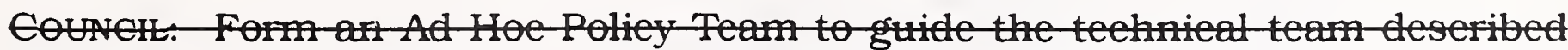
below, review andyses, and partieipate in development of the framework. Form a Ad Hoe Teehnieal-Feam to provide teehnieat input on the development of the elements of the program framework. In partieular, this should inelude the development and use of andied tools. The Ad-Hoe-Teennieal Team should 
promote understanding of the implieations of different tools and approaenes. Eouneil-staff will eonvene, faeilitate and eontribute to this group.

The-Couneit ealls on the-following groups to assist the-Couneit in developing

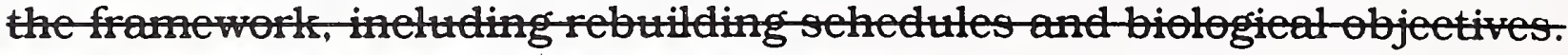

\section{Bevelopment of the Program Pramework}

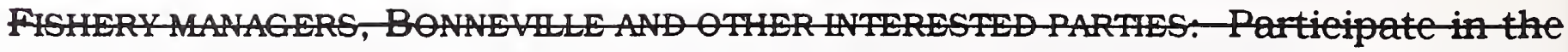
Ad Hoe Poliey and-Teehnied Teams and begin work on the tools and information neessary to develop this framerk. Provide poliey development and-diseusion neessary to complete the framerort in the-next anendment eyele. Complete proposats to the Couneit on the elements of the framework by Jant $15,1992$.

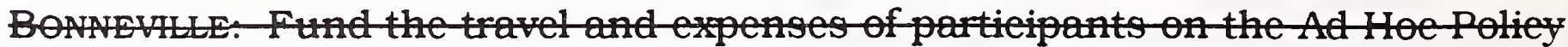
ant Teehnieat Teans and tastes nees for the groups to eomplete their mion.

\section{Short-term-Goordination- of Natural Produetion-Resenreb-and Menitering}

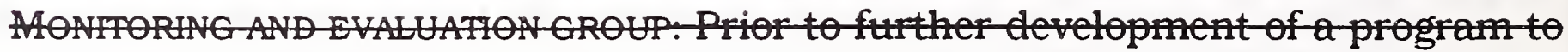
moniter and evatuate progress towart the rebuilling sehedule on phase three. eomplete reeommendations on genetie-monitoring proeedures, and prepare a

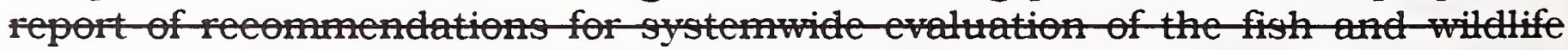
program. Also-prepare-a proposat for a coordinated approaeh to naturat produetion researeh and monitoring needs identified in amentment applieations, for eonsideration in the andromous fish amendmenteye in phase 3. These should besubmitted to the Couneil by February $1,1992$.

\section{Seientifie Advigory-Gommittee}

The-Coune st s a need for independent and impatiat revie of the program and for a teehnieatresouree-to edllon for adviee when needed. This sentiment has been eehoed by a ntmber of rewiewers. Bonnewille and the fisherygeneies and tribes met a simar need in program implementation by forming the Seientifie Rewiew Group. It is possible that the-Seientifie-Review Group eould be- restrutured to meet the planing needs of the couneit and the implementation needs of Bonnerille.

a.BONNEVILIE,FISHERY AGENCIES. With-Couneil staf, disetsy wo met the need for indepententerentifie rewiew. Speeifiedly, diseuss the use-of Bonnerille's etrrent or expanded Seientifie Review Group to fulfll this need. Report to the Couneil by February 1, 1992 with alternatives and a reementation. 


\section{(a) Regional Analytical Methods Coordination}

To develop and assess regional strategies to rebuild salmon and steelhead, and to make thisthe program framework operational, analytical tools should be developed that are both understandable and credible. A variety of tools may be developed that span legitimate scientific differences or reflect different approaches. This process should not stifle these differences, but instead should promote understanding of their implications. However, the region should integrate these tools into a unified approach. The Council applauds the considerable progress in this direction, and calls on the technical staffs of the various parties to expedite development of analytical tools and their documentation to assist decisionmaking. This will help the Couneil-set program biologieat goats, measures and performestander.

Implementation process: Begin a continuing process to review, coordinate, and develop analytical tools to assist decision making, facilitate program evaluation and review, and identify critical uncertainties. This should be a technically oriented process that is responsive to policy and management needs. A primary goal should be to promote understanding and effective use of computer models, data bases, and other analytical tools. This includes the development of standards for model documentation, modification and dissemination. Through this process, identify areas of agreement between different approaches. Where different points of view and interpretation are evident, identify the implications of these disagreements and suggest research and other actions to resolve the difference. The process should also prepare a common bibliography and input data base. This should be developed in consultation with the Coordinated Information System.

BONNEVILLE: Supply funding necessary to establish and maintain this process including travel expenses of participants and facilitation, documentation or other support.

\section{(b) Research and Monitoring Information Dissemination}

(1) BONNEVILle AND THE CORPS OF ENGINEERS: Annually publish a summary of results from all studies funded under the program. This should consist of concise descriptions of the project, results to date and future directions. Summaries should be prepared by the contractors and compiled and published by Bonneville.

(2) BONNEVILLE AND THE CORPS OF ENGINEERS: Specify as part of the above task that summaries of research originating from the fish and wildlife program be submitted to the Coordinated Information System in appropriate form for incorporation into its research information data base. Fund the development of similar summaries for prior research conducted under the fish and wildlife program. 
(3) BONNEVILLE AND THE CORPS: Hold annual symposiums at which contractors present the results of their studies, beginning in March 1993. The purpose of these symposiums is two-fold: first, to promote the use of research and monitoring information funded under this program by managers and non-research personnel, and, second, to provide peer review and coordination of research within the research community.

\section{Program-Eraduation}

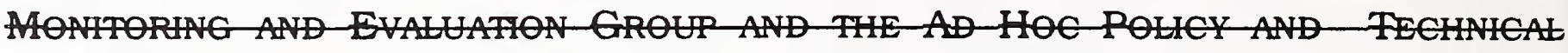
FEAMS.-Begin development of an integrated program of performanee standards and aetions to monitor and-ratute the program within the speeifieations of the program framework. This should be supplemented by an asses ment of stoel status and progress toward the rebuilding sehedule. The Couneil will revisit the neets and strueture of the monitoring andevatuation program in the next phase of the amentment proess.

\section{(c) Coordinated Information System}

a. BonNEville: Continue to fund the development of the Coordinated Information System to promote effective exchange and dissemination of information in standardized, electronic format throughout the basin. The Coordinated Information System should maintain itself as an objective vehicle for collection and dissemination of information to and from all parties. It should work in close cooperation with the fishery agencies and tribes and other concerned parties. The project should make availablee information from primary sources such as fisheries agencies and tribes, and from secondary sources such as the Fish Passage Center and the Pacific States Marine Fisheries Commission. Standardizing data formats and establishing data needs will be an ongoing responsibility of the Coordinated Information System. Include the following data bases:

\section{(1) Hatehery produetion clata base}

(1) Anadromous fish data base

The Coordinated Information System should assemble and tabulate on an annual basis and make available in electronic format all data necessary to the production, updating, and enhancement of the information in the 1985 Bonneville-funded Stock Assessment Report. The Stock Assessment Report should be revised and released by October 1992. Thereafter, the Coordinated Information System should have the responsibility to update the report on a regular basis. Other types of natural, hatchery, and system information requested for program monitoring and evaluation should be included in the anadromous fish database. Hatchery data shall be developed fin cooperation with the Integrated Hatchery Operations Team, 


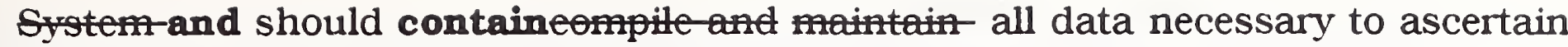
the performance of Columbia River Basin hatcheries.

\section{(2) Stoet assesment data base}

In eoperation with the Monitoring and Evatuation Group and the Ad Hoe Teehnieal Team, the- Eoordinated Information-System should assemble and tabulate- on an annul basis and make available in eleetronie format all data neessary to the produetion and uplating of the information in the 1985-Bonnevilte-funded Stoek Assessment Report and other information requested for program evatuation. Streh data should explieitly inelude meastres of the productivity of naturatly reprodueing anadromous fish-stoeks.

(2) Scientific information data base

Existing information from fish and wildlife program projects, other regional research efforts, and related national and international anadromous fish research should be compiled and made available to users in the form of a computerized bibliographic database and a systematic, readily accessible, document retrieval system. This shouldinelute sumaries of all Bonnewille and-Corps-of Engineers funded researeh and inelude appropriate researeh funded by other parthe Research data bases that are maintained by various fish and wildlife entities should be cataloged in a summary data base describing the information and detailed instructions on how to access this data.

\section{Habitat data base}

BoNNEVILLE: In coordination with the Coordinated Information System, fund creation of a data system to coorde include information to permit the evaluation of the status of the habitat upon which anadromous fish production depends in the Columbia River Basin. This should facilitate the monitoring and evaluation of carrying capacities; and survival rates; - monitoring and evaluation of human activities of for should include a hierarchical classification system. In developing and maintaining this capability, erplore options that could be more expeditious, less cumbersome and less costly such as analysis of aerial photographs. Also, explore using a standard organizing approach such as Geographic Information System.

\section{(d) Project Accounting Data Base}

BONNEVILLE: In cooperation with the fishery agencies and tribes, develop a data base and tracking system to monitor and categorize expenditures by geographic location (EPA River Reach System), species, type of action and other relevant categories. This should be developed in coordination with the CIS. 
This data base should focus on Bonneville expenditures but also include other agencies' funding activities under the fish and wildlife program. Bonneville should expedite development of this database and seek to have a working prototype within one year of adoption of this rule.

\section{(e) Evaluation of New Technologies}

The Council has previously called for proposals to explore and develop new technologies to improve survival throughout the salmon life cycle. These include requests for development of new fish marking techniques, methods for selective harvest, and the use of sound to divert salmon and steelhead away from turbines. Other new, or experimental, technologies may hold potential for contributing to the region's salmon rebuilding measures. The Council desires implementation of the measures called for to date, but recognizes that other technologies may merit development. In this measure, the Council provides an avenue for new and innovative ideas to be considered. In the short term, the process should review the new technologies identified, comment on their potential for improving saimon survival, methods for monitoring and evaluation, and recommend prioritization for funding by Bonneville.

Implementation Process: Through a scientific review panel drawn from the region and elsewhere, provide a forum where innovative or experimental methods that could contribute to the Council's program and regional fisheries management can be brought forward. Include review of measures in the Council Program calling for proposals using new or experimental technologies and comment on their potential for improving survival, and available methods for research and development. Identify other promising new technologies not currently identified by the Council or used in the region. Establish priorities for funding. If new proposals are deemed to have more promise than any identified in the Council's program, provide an explanation to the Council and the Basin Oversight Group. For projects proposed for funding, establish methods for monitoring research and time periods for reporting results to the Council. Annually review the funded proposals and repeat identification and prioritization of new research and development. 


\section{SECTION A100}

\section{INTRODUCTION: COLUMBIA RIVER, SALMON AND STEELHEAD AND THE NORTHWEST POWER ACT}

\section{(a) Overview}

Ever since the Northwest Power Act was passed in 1980, the Columbia River Basin's fish and wildlife have been the subject of increasing attention, not just from interest groups, but more and more from the public at large. A major goal of the Act is to address the impacts that the region's hydroelectric dams have had on fish and wildlife. During the past decade, significant efforts and money have been spent to protect and rebuild the affected populations.

But even that effort has not been enough for some species. Some of the region's salmon and steellead runs have been dwindling at alarming rates, so alarming in fact that, for the past two years, certain populations have been the focus of national, as well as regional attention. It is a spotlight that many feel is long overdue.

The waterays that matre-up the huge-Columbia-basin have-been the souree of a remarkable boun for the Paeifie-Northwest. For eenturies, they have providect habitat and migratory routes for fish and willife. In-reent history, they have-atso produeed eleetrieity and provided water for irrigation, navigation, reereation, munieipalities and-industry.

But even the riehest resouree has limits, and water-espeeially in the Westis a finite resouree. Over the years, competing uses for Columbia Basin-water have begun to converge-into what in some-eases is a deally eompetition, espeeially for eertain-fish-runs. This growing erisis has been evident for a number of years, and there have been signifieant and, to some-degree, sureessfut efforts to deat with-it. But time has not been on the sith of the fish. The basin's salmon and steelheal runs that use the rivers for their spawing beds, rearing areas and eorridors to and from the sea have been dwindling at alaming rates for over a eentury.

The critical condition of these fish was graphically illustrated in 1991. when only seven sockeye salmon were spotted making the mile run inland from the Pacific Ocean to their spawning grounds in Idaho's Redfish Lake. 
Of the four known to have made it to the lake, only one was a female. In mid-November 1991, to no one's surprise, the National Marine Fisheries Service officially declared these Snake River sockeye salmon an endangered species.

In April 1992, the National Marine Fisheries Service designated Snake River spring/summer chinook and fall chinook as threatened species. These the declarations triggered a set of actions required under the federal Endangered Species Act of 1973. One of these actions istll be the development of a recovery plan. The Endangered Species Act sends a clear message that--the region does not have the option of taking no action.

Fortunately, the Northwest did not lose time simply debating whether the sockeye and other runs propering--spring, summer and fall chinook--are in fact threatened or endangered. Building on its decade of experience in dealing with salmon, the Northwest began developing its own regional plan two years ago for those species that are in most critical decline. These include the wild and natural runs, particularly those that make the long journeys to and from the Snake River. The actions the region is undertaking are also expected to benefit overall salmon and steelhead populations as well. The National Marine Fisheries Service has begun using the completed phases of this - sent strong signals that it will use-a regional plan, embodied in this document, as a basis for developing its own recovery plan.

Important groundwork for the regional plan was laid in athe Salmon Summit convened in late 1990 by the region's Governors and Senator Mark Hatfield. The summit, made up of the user, policy and interest groups connected with the Columbia Basin's waterways, came up with critical short-term measures that were implemented in 1991 to stem further decline. Those measures bought the region some time. From there, development of a regional salmon rebuilding plan moved to the arena of the Northwest Power Planning Council, the interstate body that has provided a regional forum for the past 10 years through its Columbia River Basin Fish and Wildlife Program. The Council, whose members are appointed by the Northwest Governors, was directed to develop its program under the Northwest Power Act.

The Council took up where the Salmon Summit left off in early 1991 by initiating a process to amend its fish and wildlife program in four phases. The first three phases constitute a salmon rebuilding plan aimed, not only at rebuilding the three stocks proposed for listing under the Endangered Species Act, but also at aiding all weak salmon stocks. The fourth phase of the amendment process will address resident fish and wildlife and will integrate all amendments and the existing fish and wildlife program into a new Columbia River Basin Fish and Wildlife Program. 
mitigate adverse effects or allow transition time to those affected through alterations in operations, management and timing of measures; assistance in meeting the costs of adjusting to new conditions; and other means.

(b) By June 30, 1992, develop a Mitigation Plan with specific actions assigned to responsible agencies and parties. Identify capital requirements for mitigation measures, and potential sources of assistance, including the potential for use of a regionally-based trust fund. Participate in negotiating general terms and conditions of such assistance so that it will be usable to recipients.

(c) By July 31, 1992, prepare recommendations to federal agencies, state governments and others identified as potential sources of assistance. Submit a report to Congress and seek assistance from the Northwest Congressional delegation to secure approval for federal funding.

w: $\mid$ phs9|528.out 



\section{Draft Habitat Project Selection Criterial}

\section{BASINWIDE PERSPECTIVES}

A. Habitat projects affecting priority stocks such as upriver stocks on threatened and endangered species lists (States and Federal). projects in subbasins designated by NMFS as critical habitat, stocks on U.S. Forest Service (USFS) sensitive list. stocks identified in the Council's Integrated System Plan, and other weak stocks receive highest priority.

B. Complements the policies, plans, and programs of the region's state and federal fisheries agencies and Tribes. Northwest Power Planning Council's Fish and Wildlife Program. Bureau of Land Management (BLM) resource plans, USFS forest plan standards and guides, state forest practices. Tribal programs, private agricultural and other land uses. Soil Conservation Service's plans, and the Governor's Watershed Enhancement Board.

1. Coordination with emerging state and federal laws controlling ownership, extraction of minerals, and other uses of stream channels.

2. Coordination with the National Marine Fisheries Service. U.S. Fish and Wildlife Service, and other state or federal Recovery Plan.

3. Consistency with Tribal and state fishery agency natural production goals.

4. Encourage cost-sharing.

1-These proposed criteria were submitted to the Council by Bonneville persuant to language in the Council's phase 2 rule. They were titled revision 1.3. Final criteria are expected to be submutted by May 15. 1992 and will be incorporated into the draft rule. 
D. Indigenous populations are given greater priority over potential introductions of new stocks.

E. Water rights considerations.

1. State water rights reserved for instream flows.

2. Potential for private groups to maintain water rights for instream flows.

3. Future water withdrawals (municipal, agricultural. mining. hydroelectric uses) do not jeopardize projects.

F. Projects will be prioritized for funding as follows:

1. Habitat enhancement or protection projects (including opportunities for preplanning and pre-project/baseline data collection).

2. Tributary passage projects.

3. Habitat research.

\section{Waterahed Perupectives}

A. Proposals complement the biological goals and objectives of a comprehensive watershed program.

B. Current or planned activities in the watershed do not negate project benefits.

1. Land management activities in the watershed comply with more stringent guidelines such as USFS standards and guides. 
American Fisheries Society guidelines, and state water quality standards.

2. Land management activities in the watershed comply with best management practices (BMP's).

3. Trends in adjacent or watershed land management standards and guidelines are adequate to protect habitat investments.

C. Projects are consistent with trends in watershed management approaches to stream habitat enhancement.

D. An emphasis is placed on projects designed to maintain overall biological diversity.

E. Sequencing of habitat activities having short-term effects vs long-term effects within a watershed is critical to the success of watershed goals.

1. Activities are sequenced properly to protect the overall benefits expected from all projects in the watershed.

2. Instream enhancement projects yielding short-term benefits to fish are undertaken where other long term measures such as changes in land management practices are under development.

F. Overall watershed management goals are prioritized as follows:

1. Protection of existing good habitat.

2. Rehabilitation of degraded habitat.

3. Enhancement of existing unaltered habitat. 
G. Proposals involving reintroductions of anadromous fish above natural or man-made barriers would not adversely impact resident fisheries and require tribal or state agency concurrence.

H. Project does not conflict with wild and scenic waterway designations.

\section{Project Specific Considerations.}

A. Project proposals reflect thorough planning and include the following critical elements:

1. Biological objectives are well defined to obtain goals and mesh with overall watershed/basin planning.

2. Project objectives are realistic and measurable.

3. A monitoring program is specifically designed to track progress towards meeting project objectives.

4. Pre-implementation baseline information is compiled and includes:

a.) Historical fish population data. watershed, and riparian habitat condition.

b.) Current fish production/ carrying capacity estimates.

5. An operation and maintenance program is identified for protection of long-term project benefits.

6. Relationship of project to basinwide programs such as watershed scale surveys or evaluations is defined.

7. A limiting factor analysis, including a summary of the methods Coho or steelhead kevs. Battelle PNL limiting factor 
recommendations, or other) and types of specific life history and habitat data used in the analysis, is documented.

a. Identify the most limiting life stage.

b. Indicate whether low seeding levels impact the limiting factor analysis.

c. Identify how project will increase survival of target stock(s) within the watershed.

8. A risk analysis is provided which describes the level of risk for the chosen alternative habitat activity.

9. Project is cost-effective: The chosen alternative action meets the objectives of the project at the least cost.

10. Project addresses factors in a logical sequence such as:

a. The most limiting habitat factors are treated first such as temperature or water quantity/ quality.

b. Loss of a species/stock is prevented through treatment of identified limiting factors.

c. Work on private land through easement/lease agreements addresses limiting factors.

B. Actions which address multiple stocks.

1. A higher priority is given to habitat actions addressing more than one stock.

2. Actions designed for one stock do not jeopardize health/status of other stocks within the project area. 


\section{DEFINITIONS}

extinction

genetic diversity

genetic integrity

genotype

naturally spawning populations

naturalization

population
The human-induced or natural process by which a recognired taronomic entity (e.g.. species, subspecies) or a population ceases to exist.

All of the genetic variation within a species. Genetic diversity includes both genetic differences between individuals in a breeding population and genetic differences between different breeding populations.

The ability of a breeding population or group of breeding populations to remain adapted to its natural environment.

The complement of genes in an individual.

Populations of fish that have completed their entire life cycle in the natural environment and may be the progeny of wild, hatchery or mired parentage.

The process by which introduced fish successfully establish a naturally spawning population.

A group of organisms belonging to the same species that occupy a well-defined locality and exhibit reproductive continuity from generation to generation. 
velocity barrier

weak stock

wild populations

w: IphsIdefine.427
A structural barrier, such as a barrier dam or floating weir, which blocks a stream to prevent adult salmon or steelhead from migrating upstream.

Listed in the Integrated System Plan's list of stocks of high or highest concern: listed in the American Fisheries Society report as at high or moderate risk of extinction; or stocks the National Marine Fisheries Service has proposed to list. (phase one)

Fish that have maintained successful natural reproduction with little or no supplementation from hatcheries. 


\section{Summary of the Integrated System Plan for Salmon and Steelhead Production in the Columbia River Basin}

April 1992 


\section{BACKGROUND}

In 1987, to guide mitigation for salmon and steelhead losses, the Northwest Power Planning Council established an interim goal of doubling the Columbia Basin's annual salmon and steelhead runs to 5 million adult fish (measured in returns to the mouth of the Columbia River plus ocean harvest). The goal serves as a reference point or target for enhancement measures and is not driven strictly by numbers. To determine how best to double the runs, the council initiated the "system planining" effort, calling upon the basin's fish and wildlife agencies and Indian tribes to develop a systemwide plan -. the Integrated System Plan. The purpose of the Integrated System Plan is to identify strategies for increasing Columbia Basin salmon and steelhead runs in a biologically sound and sustainable manner. Copies of the Integrated System Plan (Publication 91-16) are available through the Council's office.

Under the auspices of the Columbia Basin Fish and Wildlife Authority (a consortium of state and federal fish and wildlife agencies and 13 Indian tribes in the basin), the agencies and tribes produced the Integrated System Plan and submitted it to the council in June 1991 for Council and public review. The System Plan is the ninth and final product of a three-year planning process that began in September 1987.

Fundamental to the Integrated System Plan was the development of 31 salmon and steelhead production plans for the major watersheds or "subbasins" in the Columbia Basin, which the authority submitted to the council in September 1990. These subbasin plans are the basic building blocks for the Integrated System Plan. They contain objectives and alternative strategies for increasing salmon and steelhead production in the respective drainages. From the alternative strategies, system planners recommended particular strategies for implementation based on a number of criteria, including public, agency and tribal support; technical and biological feasibility; genetic impact; and whether the alternative met management objectives.

The Integrated System Plan is organized into four major parts. The first summarizes the system goals, policies and programs that guided the subbasin and system planning process. The second part to the plan reviews information in the 31 subbasin plans by salmon and steelhead stocks. Tables help to summarize the primary information from subbasin plans. such as subbasin production objectives, the recommended strategies to meet those objectives, and projected increases in fish numbers according to computer model analyses.

The third part to the Integrated System Plan integrates all 31 subbasin plans, projecting progress toward the doubling goal, identifying major conflicts to 
reaching that goal, analyzing harvest and fish passage issues, and developing a means to evaluate the genetic risks of proposed strategies. The fourth and final part to the System Plan outlines the fish and wildlife agencies' and Indian tribes' recommendations to the Northwest Power Planning Council. The Columbia Basin Fish and Wildlife Authority has categorized hundreds of activities into three levels of priority, giving highest priority to the weakest stocks in the basin. Recommendations include stocks and areas of emphasis, specific activities to be implemented, a summary of estimated costs, future monitoring and evaluation needs, and the need for future planning and annual review of the Integrated System Plan.

In the plan. the Columbia Basin Fish and Wildlife Authority stresses that the subbasin plans and the Integrated System Plan are designed to be dynamic plans. In the spirit of "adaptive management," the fishery agencies and tribes intend to modify proposals in the subbasin and system plans as new. more accurate information about the fishery resources and efforts to enhance and protect them is obtained. 1 The Integrated System Plan and the subbasin plans are intended to guide the actions of all entities, including the state and federal fish and wildlife agencies, the Indian tribes, land management agencies, hydroelectric project operators, the Federal Energy Regulatory Commission and the Bonneville Power Administration.

The Columbia Basin Fish and Wildlife Authority supports the Northwest Power Planning Council's interim goal of doubling salmon and steelhead runs in the Columbia River system and the provisions in the Integrated System Plan to achieve that goal. It is also important to note that the Integrated System Plan was submitted prior to any ruling regarding threatened or endangered salmon stocks. While the System Plan addresses several stocks under review by the National Marine Fisheries Service under the Endangered Species Act, the Integrated System Plan does not constitute a recovery plan. All or some of the actions identified in the System Plan relative to these stocks, however, may be used in a recovery plan.

1 Adaptive management refers to a process whereby fisheries managers learn by doing. Planners were to design enbancement activities so that information could be collected to improve future management decisions. By desigaing projects that test quantitative bypotheses and lend themselves to monitoring and evaluation, managers can learn from their efforts. Using this approach, fisheries managers may move ahead with plans to rebuild the Columbia Basin's salmon and steelhead runs, despite many unanswered questions about how best to accomplish their goals. With time, the useful information revealed by these experimental actions can guide future projects. 
As mentioned above, in 1987 the Northwest Power Planning Council established an interim system goal to double the yearly Columbia Basin salmon and steelhead runs to 5 million returning adults. Because of uncertainties and the question whether this interim goal is attainable in today's Columbia Basin. decision-makers did not set a time schedule for reaching this goal. They did. however, turn to the basin's fish and wildlife agencies and Indian tribes to develop a basinwide plan for increasing the runs. Trying to determine the best way to produce the additional 2.5 million salmon and steelhead was the gist behind the three-year system planning process.

While developing the Integrated System Plan and the 31 subbasin plans, the agencies and tribes were to follow seven policies listed in the Northwest Power Planning Council's 1987 Columbia River Basin Fish and Wildlife Program. The council's policies are intended to ensure that increases in the Columbia Basin's salmon and steelhead runs are not driven by numbers to the exclusion of biological considerations, such as conservation of genetic resources. Rebuilding efforts are to lead to long-term, permanent increases and sustainable fish populations. The council's seven policies are listed below. For more discussion, see Pages 11-13 in the Integrated System Plan or Section 204 in the 1987 Columbia River Basin Fish and Wildlife Program.

1) The area above Bonneville Dam is accorded priority.

2) Genetic risks must be assessed.

3) Mainstem survival must be improved expeditiously.

4) Increased production will result from a mix of methods .. wild, natural and hatchery production.

5) Harvest management must support rebuilding.

6) System integration will be necessary to assure consistency.

7) Adaptive management should guide action and improve knowledge.

Subbasin and system planners not only followed the policies above, but took into consideration the various fisheries management programs underway in the Columbia Basin. The following list represents the major systemwide production, mitigation and harvest programs that have shaped the numerous strategies proposed in the plans. In addition to the list below, the system and subbasin planners considered various state and federal laws; Indian treaties; and management plans of individual state fish and wildlife agencies. the U.S. Forest Service. Bureau of Land Management and others. For lists of additional agencies, laws and programs, see individual subbasin plans.

- Columbia River Fish Management Plan (United States v. Oregon)

- United States-Canada Pacific Salmon Treaty

- Columbia River Fisheries Development Program (Mitchell Act hatcheries) 
- Lower Snake River Compensation Plan

- Columbia River Basin Fish and Wildlife Program

\section{Summary of Subbasin Plans}

In September 1990, the Columbia Basin Fish and Wildlife Authority submitted 31 subbasin plans for the major drainages in the Columbia River Basin. The primary purpose of the subbasin plans was to recommend salmon and steelhead production strategies for each subbasin. The preferred strategies propose a variety of actions, including riparian and instream habitat restoration, screening of irrigation diversions. and changes in land and water management. The subbasin plans contain a description of the subbasin and its salmon and steelhead resources, habitat protection needs, major constraints and opportunities, critical information gaps, production objectives, altemative strategies for increasing salmon and steelhead numbers, and modeling results.

The Yakima River Subbasin Plan, for example. presents objectives and alternatives for increasing spring chinook salmon, among other species. According to the plan, spring chinook numbers in the Yakima are a fraction of historical figures because of several factors, including overfishing, the construction of unladdered dams, unscreened diversion canals, and the dewatering of spawning and rearing habitat for irrigation purposes. The mean number of adult spring chinook estimated to return to the Yakima in the 1970s was a perilously low 384 fish. Since 1980, runs have increased, partly due to the reconstruction of several passage facilities, and restrictions on ocean and inriver harvest. According to the subbasin plan, current major constraints to spring chinook production include suboptimal instream flows, inadequate fish passage facilities at irrigation diversions, degraded riparian and instream habitat, and excessive water temperatures during the summer. Critical data or information missing, which needs investigation, includes the cause and magnitude of smolt losses, the quantification of the relationship between instream flows and smolt production, and refined estimates of carrying capacity (the number of spring chinook the Yakima Subbasin can sustain).

The Yakima Subbasin Plan proposes several production objectives for Yakima spring chinook. including 1) increasing egg deposition by increasing the amount of usable habitat and decreasing pre-spawning mortality, 2) increasing the survival of spring chinook from the fry stage to the parr stage. 3) increasing pre-smolt survival during the winter. and 4) maximizing sustainable yield (the number of spring chinook in excess of those required to spawn and maintain a particular population size) in a manner that is consistent with long-term conservation of genetic fitness and the experimental goals of the Yakima/Klickitat Production Project (an experimental supplementation project involving a hatchery and satellite facilities funded through the Northwest Power Planning Council's 
Columbia River Basin Fish and Wildlife Program). To reach these and other production objectives, the subbasin plan recommends implementing a strategy that, among other actions, includes implementing the Yakima/Klickitat Production Project, increasing the amount of habitat available to spring chinook in the Yakima Subbasin. reducing smolt losses in the Yakima by half, renovating fish bypass facilities on irrigation diversions in the Yakima, and restoring riparian habitat. According to modeling results, implementing the preferred strategy would increase the number of spring chinook by an estimated 38.000 adults.

With a few additions, the strategies and actions listed in the Integrated System Plan come directly from the subbasin plans, such as the Yakima River Plan. Because the Integrated System Plan is organized by salmon and steelhead stocks, rather than subbasins, the System Plan summarizes the subbasin plans by aggregating stocks into "system integration units." Each system integration unit for a particular species or race, such as mid-Columbia spring chinook, is composed of several stocks, one being Yakima spring chinook, that return to the individual subbasins within that particular region. Spring chinook, for example, are not managed or harvested uniformly throughout the Columbia Basin. Thus. for planning purposes, the System Plan divides spring chinook into various stocks. Planners first divided the species into two groups .. those fish returning to areas above Bonneville Dam and those returning below Bonneville Dam. These two groups of fish were then further divided into system integration units, stocks returning to various regions within the Columbia Basin. System integration units were used for organizational purposes only. For the list of system integration units used, see Table 2 on Pages 28-29 in the Integrated System Plan.

For each system integration unit, the System Plan summarizes the status of salmon and steelhead stocks, factors limiting production, production objectives. the preferred strategies for achieving the production objectives, and modeling results. Tables help to summarize this information.

\section{System Analysis}

The analysis of the subbasin plans revolved around a computer model called the System Planning Model. The model is a computer representation of the life cycle of salmon and steelhead in the Columbia Basin. Using the System Planning Model. planners estimated the number of adult fish that might result from implementing a proposed strategy. For a complete discussion, see Pages 15-18 in the Integrated System Plan.

Because management goals differ among stocks and may change in the future, it was necessary to assume some standard point for comparison of the subbasin plans. Thus, for purposes of comparing the production potential of various strategies, planners estimated the number of fish at the point of maximum sustainable yield (the point in a population where the number of fish in excess of 
those required for spawning is greatest. which usually occurs at one-half to twothirds of the maximum population size). Planners also analyzed all production strategies using two scenarios for mainstem passage survival. The first assumed 1991 passage conditions in regard to the presence or absence of bypass systems. the efficiency of these systems to collect migrating fish, and the proportion of fish being transported around the dams by barge or truck. The second scenario simulated conditions as if all guidance, bypass and transportation measures in the 1987 Columbia River Basin Fish and Wildlife Program were implemented and working as planned.

\section{SMART ARalyois}

To help select the preferred strategies for each subbasin, subbasin planners used a decision-making tool known as the Simple Multi-Attribute Rating Technique (SMART). SMART examined each proposed strategy according to five criteria:

1) Extent the subbasin objectives were met.

2) Change in maximum sustainable yield.

3) Impact on genetics.

4) Technological and biological feasibility.

5) Public support.

Planners used the SMART values to determine which strategy for a particular fish stock rated highest across all five criteria. If more than one of the proposed strategies shared the same or similar value, system planners considered other factors. such as cost, in the selection process. Some special cases arose where the planners' preferred strategy did not correspond with the SMART results. In those cases, the planners provided the rationale for their selection.

\section{Cost Analyais}

In general. cost was not used as a criterion in developing recommended strategies. As stated in the 1987 Columbia River Basin Fish and Wildlife Program. economic costs are considered as a criterion when two or more alternatives are equally effective ways of reaching the same sound biological objective. The Bonneville Power Administration, in cooperation with the Columbia Basin Fish and Wildlife Authority, is conducting a cost effectiveness study.

The cost estimates provided in the subbasin and system plans represent new or additional costs necessary to implement the alternative strategies proposed. Because of the variation in life expectancies among actions, total costs were standardized to a 50-year period. Planners standardized costs for installing instream structures, improving riparian areas and screening water diversions. For other habitat enhancement activities, including the removal of instream 
barriers, planners developed their own cost estimates in consultation with resident experts. Planners also standardized costs for new hatchery production.

Subbasin planners tried to estimate all direct costs of alternative strategies except for the purchase of water rights. No cost estimates were made for actions that involve purchasing water due to the difficulty of estimating the amount needed, assigning a price, and whether local water law allows such transactions. Nor were estimates made as to the cost of implementing the proposed mainstem flow improvements (see Pages 283-284 in Integrated System Plan). Indirect costs, such as changes in water flows or changes in the hydroelectric system operations, were not addressed.

\section{Integration and Analysis}

\section{Purpose of Integration}

The 31 subbasin plans form the basis for identifying strategies to double the annual salmon and steelhead runs in the Columbia River Basin. The subbasin plans, however, deal strictly with stocks and enhancement needs at the subbasin level. Because of the number of individual stocks, management cannot isolate subbasins and hope to achieve any meaningful enhancement. Rather, stocks must be addressed systemwide. Consequently, planners combined or integrated the subbasin plans to determine, among other things, if the proposed strategies will reach the doubling goal.

The primary goal or purpose of integration is to combine all 31 subbasin plans into one unit or one systemwide plan that is a collection of elements working in concert with one another to produce an additional 2.5 million returning salmon and steelhead annually. Specifically, integrating the subbasin plans 1) provides a basinwide list of production actions, which may be prioritized to achieve the doubling goal; 2) encourages cooperation, coordination and efficiency in resource management; 3) identifies conflicts among subbasins and management entities that could preclude success in any one subbasin; and 4) enables the analysis of fish production, genetics, passage and harvest on a systemwide level.

\section{Major Conflicts and Issues}

The Columbia Basin Fish and Wildlife Authority identified major management conflicts and issues in the basin that could interfere with achieving the doubling goal or subbasin objectives, or even prevent the implementation of the system and subbasin plans. In addition to legal and institutional considerations, the conflicts fall primarily into three interrelated categories .. passage, harvest and production: 


\section{Passage}

- Hydroelectric system operations

- Corps of Engineers rule curves

- Congressiond project mandates

Harvest

- Subbasin vs. system management and objectives

- Intraspecific mixed-stock harvest

- Interspecific mixed-stock harvest

\section{Production}

- Imbalance of natural and artificial production

- Potential imbalance in species production

- Genetic risk and imbalance

- Disease

Conflicts Regarding All of the Above

- Threatened/endangered listing

\section{Passage}

The Columbia Basin Fish and Wildlife Authority identified the loss of juvenile and adult fish due to migration delays and turbine mortality from dams on the Columbia and Snake rivers as the major constraint to achieving the doubling goal. Preliminary analyses in the Snake River indicated that if flows at Ice Harbor Dam increased from 1991 mean levels of approximately 93.000 cubic feet per second (cfs) to the 140.000 cfs proposed by the Columbia Basin Fish and Wildlife Authority, the total adult return projected for the recommended strategy for Middle Fork Salmon River spring chinook would increase from roughly 7.700 to 21.800 adults. Increased flow could substantially improve fish runs and substantially increase the effectiveness of subbasin strategies, particularly within the upper Snake River subbasins, and upper and mid-Columbia regions. Additional fish bypass screens would also have a major positive effect in the upper Columbia. where screens are largely nonexistent.

Other key issues revolve around Congressional project mandates and how the U.S. Army Corps of Engineers operates under its flood control rule curves. The rule curves, which are graphic guides to the use of storage water, dictate how and when a storage reservoir will be drawn down in anticipation of spring flooding. Rather than coordinating water releases when outmigrating smolts could benefit. the flood control rule curves call for releasing water from reservoirs during the winter, when the increased flows are of no use to migrating smolts. Under the 
rule curves, the reservoirs must then be allowed to refill and, thus, in years when water is scarce, dam operators are less likely to spill water during the fish outmigration to help simulate the spring runoff. Congressional mandates for projects, such as designating the main purpose of a dam for irrigation or hydroelectric generation, also create obstacles to modifying dam operations in favor of fish.

\section{Harvest}

Harvest management conflicts can occur within a species (intraspecific), between species (interspecific), or between the subbasin and mainstem objectives. The Integrated System Plan points to the impact of intraspecific and interspecific mixed-stock harvests in the ocean. Columbia River and tributaries as the primary harvest issue. Mixed-stock harvests refer to fisheries where more than one stock or species is present at the same time. While fishing for one species, for example, fishermen intercept other species, usually referred to as "non-target" species, which may be less abundant and thus highly susceptible to overharvest. Use of selective fishing gear, such as gill nets with a specific mesh size, can help control the problem, but does not eliminate it. In the case of intraspecific mixed-stock harvests, generally hatchery components of a stock are more numerous, yet cannot be separated in the ocean or Columbia mainstem from the less numerous wild component. Thus, either harvest is constrained or weaker stocks are overharvested.

Another harvest issue concerns the inconsistencies between subbasin objectives and mainstem harvest objectives. Production strategies and utilization (harvest) objectives proposed in the subbasin plans were developed independently without considering intraspecific and interspecific harvest conflicts in the mainstem that could arise. As an example, intensive enhancement of upriver bright fall chinook stocks without any increase in wild Group A or Group B summer steelhead, which move upriver at the same time as upriver brights, would mean that the treaty Indian fall chinook fishery in Zone 6 would be constrained from harvesting the large increase in fall chinook due to wild steelhead interception limitations.

Another example of subbasin objectives not conforming with the current mainstem goal is Snake River spring chinook. The collective subbasin goal is about 205.000 spring chinook, yet the interim Columbia River Fish Management Plan goal is 35.000 adults entering the Snake River, which falls far short of achieving subbasin objectives.

Production

Examples cited for harvest management conflicts also refer to production: an "imbalance" in salmon or steelhead production by species, stock or region 
could strain mixed-stock management efforts in the ocean, mainstem and tributaries. Large increases in hatchery components without corresponding increases in natural production may mean genetic risk for stocks or even species. Disease is another production issue that could impact the success of subbasin objectives and strategies. Effective disease control in hatcheries is necessary to control infectious hematopoietic necrosis (IHN), bacterial kidney disease (BKD). whirling disease, viral hemorrhagic septicemia (VHS) and others.

\section{Supplementation}

Pages .199.221 of the Integrated System Plan address the role of supplementation as one of the strategies that may be used for restoring natural production of salmon and steelhead populations in the Columbia Basin. The plan defines supplementation "as the stocking of fish into the natural habitat to increase the abundance of naturally reproducing fish populations." The discussion includes the uses of supplementation, when it may be appropriate. approaches to supplementation, supplementation technology, risk analysis and research needs.

According to the System Plan. supplementation is considered a tool for rebuilding natural fish populations: not a panacea. It can be used to assist in rebuilding natural stocks, to replace extirpated stocks (stocks that no longer exist in a particular stream or region), or to introduce and establish a stock in a barren habitat. Supplementation may be appropriate when a stock is considered to be at high risk and a policy decision is reached to implement restorative measures to reverse the trend toward extirpation, and the physical and biological constraints on the natural stock (such as habitat conditions, passage and water quality) make its restoration feasible.

Although the fishery agencies and tribes consider supplementation a potential tool for increasing natural fish production, there is not a detailed understanding of which techniques work best under which circumstances. Because of these uncertainties, planners recommend taking a phased approach to supplementation, using experimentally designed studies and applying the concept of adaptive management. For more discussion, refer the supplementation section from the Integrated System Plan, which is attached to this summary.

\section{Genetic Evaluation}

The Integrated System Plan points out that planning tools to aid genetic risk assessment of various strategies and to guide progress toward genetic conservation goals are in various stages of development. While it was too early to formally apply some of these developing approaches as tools, planners prepared a simplified assessment of genetic resource management opportunities, which consisted of a brief questionnaire that classified populations or stocks into six 
"genetic management opportunity" categories. The results of this initial process showed that the majority of the subbasin recommended strategies were in the production approach category characterized by minimizing genetic risks in the use of artificial propagation for conservation or restoration of natural spawning capacity. However, some native stocks that currently receive no enhancement would be committed to experimentation or full-scale production with artificial propagation. While the questionnaire was useful for characterization, a more extensive effort to assess and reduce genetic risks, and an evaluation of trade-offs between short-term progress and long-term sustainability is recognized as being needed.

\section{Fisheries Agencies and Tribes Recommendations}

\section{Stocks and Areas of Emphasis}

The Integrated System Plan prioritizes the various stocks in the Columbia Basin for future enhancement. Of the 52 stock groupings, planners characterized eight (15 percent) as stocks of "highest concern" .. those representing important genetic resources and in jeopardy as a result of low run size. Thirteen (25 percent) were identified as stocks of "high concern" .. those not necessarily currently in jeopardy, but possessing characteristics crucial to long- term diversity and stability. The plan lists 19 (37 percent) as "major production opportunities." seven (13 percent) as "minor production opportunities," and five (10 percent) as "non-program stocks." those not recommended for enhancement under the Columbia River Basin Fish and Wildlife Program. The majority of the high priority stocks are located in subbasins above Bonneville Dam; they are as follows.

Stocks of Highest Concern

- Wild/Natural Snake River Spring Chinook

- Snake River Summer Chinook

- Wild Snake River Bright Fall Chinook

- Natural Lower Columbia Fall Chinook (Sandy River)

- Natural Lower Columbia Early-Returning Coho

- Natural Lower Columbia Late-Returning Coho

- Salmon River Sockeye

- Okanogan Sockeye

Stocks of High Concern

- Hatchery Snake River Spring Chinook (upper Salmon River)

- Natural Upper Columbia Spring Chinook

- Natural Lower Columbia Spring Chinook

- Upper Columbia Summer Chinook 
- Hatchery Snake River Bright Fall Chinook

- Natural Lower Columbia Fall Chinook (small mainstem tributaries)

- Wild/Natural Snake River Summer Steelhead. Groups A and B

- Wild/Natura Upper Columbia Summer Steelhead. Group A

- Wild/Natural Mid-Columbia Summer Steelhead. Group A (Wind. White Salmon. Walla Walla. Klickitat and Hanford Reach on mainstem)

- Wild/Natural Lower River Summer Steelhead

- Wild/Natural Winter Steelhead

- Wenatchee Sockeye

- Natural Lower Columbia Chum

\section{Recommended Activities}

With these priorities in mind, planners then prioritized specific activities for implementation into three levels. The first level. "Early Implementation Activities." represents high priority activities directed toward the stocks of high and highest concern that need to be implemented as soon as possible. Activities in the second level. labeled "Near- Term Activities." continue to enhance stocks of high concern as well as provide significant production opportunities for other stocks. These are ongoing projects or new starts to be implemented prior to 1998. The third level of actions. labeled "Additional Activities," represents the lowest priority projects.

Leading the entire list of activities is a three-part system strategy aimed at improving mainstem migrant survival (see Pages 283-284 in the Integrated System Plan). The Columbia Basin Fish and Wildlife Authority believes this strategy could substantially improve survival of salmon and steelhead passing through the system and should be implemented prior to or in concert with Level 1 subbasin activities. It would, in turn, greatly enhance the productivity of previously implemented enhancement measures as well as those activities proposed in the three levels of priority. Briefly. the strategy calls for:

A) Providing fish migration flows or equivalent velocities as contained in the Columbia Basin Fish and Wildlife Authority flow proposal.

B) The Bonneville Power Administration to fund the implementation of alternative measures, if necessary, to fulfill the Columbia Basin Fish and Wildlife Authority flow proposal or provide equivalent velocities, including modifying flood control and refill requirements, reducing pool elevations behind mainstem dams to increase water velocities, obtaining additional water supplies by renting water from upriver water banks, or buying storage contract space. 
C) The Bonneville Power Administration to fund the fishery agencies and tribes to develop an annual plan for mainstem passage improvement that is integrated with other production and harvest plans. The planning effort shall describe research priorities, facility modifications, operational measures and maintenance needs.

A handful of activities listed in Levels 1.3 are marked with a pound sign (\#). These reflect cases where the Columbia Basin Fish and Wildlife Authority was unable to reach consensus prior to submitting the Integrated System Plan. Some of the issues reflect deep- seated differences in management philosophies. Most of these differences surfaced in December 1990 when the Columbia River InterTribal Fish Commission published its "Integrated Tribal Production Plan, Volume 1," proposing a methodology for pursuing supplementation actions, a number of changes to existing Snake River hatchery programs, and associated revisions to the draft Integrated System Plan. Rather than delay submitting the System Plan, the authority members agreed to note the unresolved issues and defer resolution to subsequent processes.

\section{Production Estimates}

System Planning Model results estimate that implementing the recommended strategies outlined in the subbasin plans (and listed under Levels 1.3 in the Integrated System Plan) would result in approximately 1.8 million additional adult salmon and steelhead (chum and sockeye contributions, among others, were not modeled and are not included in the estimates). This represents approximately 72 percent of the interim doubling goal. This estimate is based on the assumption that all measures to enhance fish passage survival on the mainstem that appear in the 1987 Columbia River Basin Fish and Wildlife Program will be implemented and successful. Table 1 summarizes the System Planning Model results for the subbasin preferred strategies by system integration unit. Note that these numbers are approximations based on modeling analysis; the System Planning Model was used as a relative measure of the impact of different actions or strategies.

According to the Integrated System Plan, increasing mainstem migrant survival is key to enhancing and restoring Columbia Basin runs. Cumulative mortality of fish passing through the hydropower system over nine dams has been estimated at up to 96 percent for juveniles and 61 percent for adult fish. While smolt-to-adult survival rates for spring chinook commonly range from 3 percent to 5 percent in the Northwest, the survival rate for Snake River stocks has recently averaged about 0.2 percent. Improving the survival rate to only 1 percent could increase returns to the Snake River by five times -. from approximately 19.000 to 95.000 adult fish. 
Because the effects of enhanced flows were estimated only for spring chinook and summer steelhead in the Umatilla. Methow and Middle Fork Salmon rivers, the Integrated System Plan does not project the combined effects of enhanced flows for all stocks in all subbasins. Planners, however, expanded the Middle Fork Salmon River projections to the Snake River region: the proposed flow enhancement increased production by 182 percent for chinook and by 214 percent for steelhead .- an increase of approximately 0.9 million fish. Planners concluded that if flow enhancement can produce an additional 0.9 million fish from yearling chinook and steelhead production in the Snake River region alone. production increases from flow enhancement for all stocks in all regions would exceed 1 million additional fish. In combination with the subbasin strategies listed in Levels 1.3 (1.8 million adult fish), flow and passage improvements could more than achieve the doubling goal.

In addition to the mainstem survival strategy and the subbasin strategies. the Integrated System Plan outlines six mainstem production strategies to increase fish numbers (see Pages 243-247). The strategies are primarily increases in artificial production and could produce approximately 1.2 million adult fish. These six strategies are low priority items and fall within the Level 3 activities.

The potential fish increases suggest that planners can reach or exceed the interim doubling goal through the subbasin recommended strategies and mainstem flow and passage measures alone. minimizing genetic risk to naturally reproducing populations. The six additional production options in the mainstem will produce large numbers of fish and present less obstacles to implementation. but at the same time, pose greater risk to natural production. 
System Planning Model results (in numbers of adult fish) for the subbasin preferred strategies by system integration unit. The baseline refers to the estimated average run size during the past five to 10 years; modelers calibrated the model to generate a run size that equalled the average run size of a stock provided by planners. The contribution to the Northwest Power Planning Council's goal is the increase from the baseline scenario in the total return to the mouth of the Columbia plus prior ocean harvest. For a complete list of stocks not modeled, see Table 59 on Page 237 of the Integrated System Plan.

\section{System Integration Unit}

Lower River Spring Chinook

Mid-Columbia Spring Chinook

Upper Columbia Spring Chinook

Snake River Spring Chinook

Upper Columbia Summer Chinook

Snake River Summer Chinook

Lower River Fall Chinook

Mid-Columbia Fall Chinook

Upper Columbia Bright Fall Chinook

Snake River Bright Fall Chinook

Winter Steelhead

Lower River Summer Steelhead

Mid-Columbia Summer Steelhead

Upper Columbia Summer Steelhead

Snake River Group A Summer Steelhead

Snake River Group B Summer Steelhead

Early-Returning Coho (Type S)

Late-Returning Coho (Type N)

Upriver Coho

Sockeye

Chum

TOTAL
Baseline

42.700

24.500

23.500

56.200

13.400

17,000

158.700

30,500

101.200

14.700

34.100

32.100

44.900

38,100

89.700

56,800

64.400

41,200

26.200

N/M

$\mathrm{N} / \mathrm{M}$

909.300
Contribution to Council's Goal

55.500

103.300

71.800

122,000

65.300

46.400

206.300

111.000

126.500

30.500

49.800

58.800

116.600

122.500

166.000

122.700

85.000

46.500

39.500

$\mathrm{N} / \mathrm{M}$

$\mathrm{N} / \mathrm{M}$

1.746 .000 
The Integrated System Plan summarizes the estimated costs of implementing the recommended strategies proposed in the subbasin plans, which appear in Levels 1.3 in the System Plan. Estimates totaled approximately $\$ 394.3$ million for capital costs (one-time expenditures) and \$20.4 million for yearly operation and maintenance costs (incurred annually for 50 years). Costs for projects above Bonneville Dam accounted for 78 percent of the capital and 80 percent of the operation and maintenance. The estimated costs for improving habitat (such as installing instream structures, planting riparian vegetation. stabilizing banks and fencing riparian areas), removing barriers to passage. screening diversions and other activities not directly associated with hatchery production accounted for approximately $\$ 309.3$ million in capital costs and $\$ 10.9$ million in annual operation and maintenance costs.

These cost estimates represent new or additional costs to the 1987 Columbia River Basin Fish and Wildlife Program. They do not include costs for water acquisitions or changes in water flows or in hydroelectric system operations. As mentioned earlier. planners did not attempt to estimate the cost of implementing the three-part mainstem migrant survival strategy. Preliminary estimates of the cost to fully implement plans in the 1987 Columbia River Basin Fish and Wildlife Program to improve passage at the mainstem Columbia and Snake River dams range from $\$ 160$ million to $\$ 190$ million.

Costs were also summarized by priority level and species. Estimated costs (capital and $O \& M$ ) over 50 years to implement the recommended strategies totaled approximately $\$ 404$ million for Level 1, \$546 million for Level 2, and $\$ 515.5$ million for Level 3. Because some projects, and thus their costs, are repeated for several species, these totals may overestimate the costs of implementing the actions.

A summary of hatchery needs identified about 36.3 million smolts and 24 million juveniles and fry at an estimated $\$ 85$ million in construction costs and $\$ 9.5$ million in annual operation and maintenance costs. New hatchery costs above Bonneville Dam accounted for approximately 75 percent of the total hatchery costs, 84 percent of the smolts. and 52 percent of the juveniles and fr:

Planners standardized costs for all new hatchery production basinwide. To account for the variability in fish stocking sizes. estimates were based upon the cost per pound of fish produced. For consistency, estimated capital costs of constructing a new, modern fish hatchery were based on $\$ 23$ per pound of fish produced. regardless of the size of fish produced. Estimated operation and maintenance costs per year were based on a generic cost for all stocks and sizes of $\$ 2.50$ per pound of fish produced. 


\section{Monitoring and Evaluation}

Throughout system and subbasin planning, planners systematically identified areas of information that need refinement or are missing altogether .. information referred to as critical uncertainties. The Integrated System Plan discusses three types of critical uncertainties .. tributary production, mainstem passage, and ocean and estuary survival. Major areas of uncertainty include estimates of smolt capacity, estimates of fish survival rates in the tributaries, the efficacy of supplementation strategies, segregation of mainstem passage mortality. and estimates of fish survival in the ocean and estuary.

A major area of uncertainty while working with the System Planning Model was the estimation of smolt capacity, or the number of smolts a particular stream can support. Although a fairly elaborate method was devised for its estimation, the method was limited by the amount of information available on characteristics for individual tributaries and how the characteristics of a stream are related to its smolt capacity. There is also, therefore, uncertainty as to how enhancements to a subbasin will change its smolt capacity.

Also needing refinement are survival rates during the three stages of juvenile and adult salmon and steelhead life histories .. survival from egg to smolt, smolt-to-smolt survival (which refers to smolt losses within a tributary as fish move through unscreened irrigation diversions, for example), and prespawning survival of retuming adults. The efficacy of supplementation strategies has also been difficult to project, partly due to a lack of data on the survival of outplanted fish at different life history stages. It has especially been difficult to project for lack of information on the reproductive success of returning adults of outplant programs.

Another major uncertainty lies in the inability to segregate mortality in the mainstem into various components. The three components of mortality where most of the uncertainty lies are turbine. transport and reservoir mortality. Without knowing specifically where mortality occurs, it is difficult to propose solutions for reducing it. Refining ocean survival rates for salmon and steelhead is another area needing investigation, as is obtaining reliable estuary survival rates for juvenile salmon and steelhead below Bonneville Dam.

Policy issues identified in the Integrated System Plan relate primarily to harvest and land management conflicts, costs and genetics. The harvest of weak stocks with healthy stocks in a mixed-stock situation is a problem that has not been addressed in analyses conducted so far. Another uncertainty is the resolution of conflicts between system planning and other state and federal plans. Similarly, it is not clear how land and water use will conflict with proposed strategies for enhancement. Cost issues have not been resolved either. Questions include how it will be done and by whom; what is the cost effectiveness of 
proposed strategies and activities as well as current activities; and how will decisions for implementation be made in the light of limited funds. Many genetics questions remain unanswered also, such as what steps might be taken in the midst of harvest conflicts, supplementation initiatives and the Endangered Species Act to protect genetic resources while permitting a reasonable harvest and progress toward rebuilding.

\section{Future Planning and Implementation}

The Integrated System Plan provides a foundation for future actions to achieve the doubling goal. It is, however, like all planning efforts, of value only so long as it is dynamic and continuously updated. Ongoing planning will be required to assure that actions are under way. that they are recognized as completed. that they have or will cause change, and that change is accommodated.

The Columbia Basin Fish and Wildlife Authority proposes, with adequate funding. to provide an annual assessment of Integrated System Plan implementation, together with new actions or changes if needed. According to the System Plan. this ongoing planning effort should use research results and knowledge gained through program implementation and monitoring to update the concepts, objectives and actions in the System Plan; to generate future amendments to the Columbia River Basin Fish and Wildlife Program; and to guide the "Implementation Planning Process."

\section{Public Comments}

Public involvement played an important role in the development of the subbasin plans and the Integrated System Plan. Technical and public advisory committees advised planners on technical issues, and helped develop subbasin objectives and strategies for increasing salmon and steelhead numbers. In August 1990. the draft Integrated System Plan was released for public comment: the Columbia Basin Fish and Wildlife Authority and the Northwest Power Planning Council held public meetings throughout the basin. Over 100 individuals and organizations submitted comments on the subbasin and system plans. In June 1991. the authority submitted to the council the Integrated System Plan as well as the Summary and Responses to Public Comments on System Planning Products (Request document 91-17).

Because inconsistency regarding objectives in the subbasin plans was a major complaint. members of the Columbia Basin Fish and Wildlife Authority developed a more consistent presentation of objectives, including numencal objectives where possible. Among other things, planners included addiunnal justification for recommended strategies in response to concerns that rationale for 
several recommended strategies was insufficient. In plans where modeling numbers were available, planners presented the System Planning Model results for alternative and recommended strategies in a more consistent manner.

Regarding the Integrated System Plan, more comments were directed toward mainstem passage, particularly the need for more flows, than any other single issue. Some of the other major issues raised over the draft System Plan were the balance of wild, natural and artificial production; the role of supplementation; the protection of genetic resources; the coordination of harvest management; and the effects of fish enhancement on other land uses, such as cattle grazing and irrigation.

Several individuals and organizations commented on mainstem passage issues. Some stated that only through resolution of fish passage issues on the mainstem Columbia and Snake rivers will the council's goal be attained. Many stated that sufficient flows for downstream and upstream migration are of primary importance. They also supported reducing reservoir mortality and installing screens on hydroelectric facilities. Some noted that the hydropower interests should be responsible for providing flows and spill to help fish runs, while one organization stated that the Bonneville Power Administration must include fish benefits as a constraint on generation, development of new resources, marketing. sales and transmission.

While some people complimented the Columbia Basin Fish and Wildlife Authority for emphasizing natural production and protection of wild stocks, others expressed concerns that the Integrated System Plan put too much emphasis on hatchery production. They stated that wild and natural production opportunities need further investigation and that a better job needs to be done in determining where natural production is occurring and the magnitude of this production. People also raised the point that hatchery programs must be continuously reviewed, evaluated and coordinated throughout the basin, as well as have genetically sound operations plans and routine genetics evaluations. Many stated that more information is needed on the effects of hatchery introductions on wild stocks.

Several comments pertained to supplementation. Many people expressed their reservations over outplanting hatchery fish to rebuild natural production and their reservations over the System Plan's reliance on supplementation. They were concerned about the potential effects on wild stocks. One organization asked that if a major uncertainty is smolt carrying capacity of subbasins, how then can hatchery outplanting be conducted and not impose substantial risk to wild stocks rearing in these streams? Some stated that supplementation should include careful monitoring to ensure that wild stock goals are met. 
Many of those who commented on genetics supported the idea that genetics should be an important consideration in restoring the basin's salmon and steelhead runs. While some commended the System Plan for considering genetics. others expressed their disappointment that genetic considerations were of secondary importanc. Some organizations recommended the adoption of a genetic conservation goal or policy that translates into specific objectives. Many agreed that the initial genetic assessment in the System Plan was appropriate, but that further work was necessary.

In regards to harvest, several people believed that harvest issues were not adequately addressed in the Integrated System Plan. Some said that while the plan describes several harvest management problems, it offers no resolution or suggestions to address them. As a result, some expressed concerns harvest conflicts will continue to threaten the gains made under enhancement programs. While some of those who commented said there should be greater restrictions on harvest, others stated that harvest should be increased. Several people commented on how harvest should be allocated in the future. One person expressed concern that benefits from the System Plan will largely accrue to the lower river and, thus, those who have suffered the greatest losses (upriver interests) will benefit the least. Others brought up the question of how increased hatchery production would impact harvest, cautioning that increased harvest on hatchery fish could harm weak stocks.

Several comments were submitted regarding land and water management issues. Many people pointed out the need for closer coordination with land management agencies over habitat protection and other fish enhancement measures. Some supported while others opposed recommendations in the System Plan to reduce grazing allotments, alter grazing strategies, and improve the efficiency of irrigation practices. Some of the land management agencies pointed out that some of their policies conflict with recommendations in the System Plan. but offered their assistance and cooperation in resolving the issues. Several people commented on habitat issues, emphasizing the importance of good riparian and instream habitat conditions. Many stated that habitat protection and restoration should be a priority, as should screening irrigation diversions. Others suggested that the responsibility for habitat protection and restoration should be shared by all parties that caused habitat changes to occur. 
Attachment 1 (from the Integrated System Plan)

\section{SUPPLEMENTATION}

Introduction

This particular part of the Integrated System Plan addresses the role of supplementation as one of the strategies that may be used for restoring natural production of anadromous salmonid populations in the Columbia River Basin. Depending on the particular circumstances, supplementation may be used by itself or in conjunction with other management strategies for restoring natural production such as habitat restoration and maintenance, improvement of tributary and mainstem river passage survival, improvement of estuarine and ocean survival, and harvest management by escapement objectives to allow the population to optimally seed available habitat. Above mainstem dams, all measures may need to be employed simultaneously to achieve success.

\section{Ecological Complexity and Degradation}

Efforts to restore naturally reproducing salmonid fish populations in the Columbia Basin must begin with an understanding of the diverse and complex biology and life history of these populations. Not only are many species and races involved, but these fishes use diverse freshwater, estuarine, and marine habitats during the different stages of their life cycles (Davidson and Hutchinson 1938; Northcote 1969; Ricker 1972; Howell et al. 1985).

Superimposed upon this natural complexity is man's intervention in the form of timber harvest and removal of riparian vegetation (Chamberlain 1982), forest roads (Yee and Roelofs 1980), water transportation of logs (Sedell and Duval 1985), agriculture and irrigation withdrawals (NPPC 1986), livestock grazing on riparian areas (Platts 1981), mining (Martin and Platts 1981), urban development (NPPC 1986), fishing (NPPC 1986), and hydroelectric development (Raymond 1979; NPPC 1986). Numerous studies have been conducted to quantify the detrimental effects of these activities on anadromous populations and their habitat.

\section{Systems Approach to Restoration}

Because the Columbia River Basin is a complex system with many interacting components, an improvement in one component will not necessarily result in improvement of the system as a whole. Thus, the function of any component and its manipulation can only be properly assessed in relation to the system of which it is a part. In the Columbia Basin, this approach has been called "gravel-to-gravel" management. 
A first step in restoration of natural fish populations is an assessment of population "health." the stock's biological characteristics, the difference between the quality and quantity of present and former habitat, analysis of the factors limiting abundance, and modes of interaction of these factors (Table 55). Understanding the physical and biological requirements for each life history stage of all stocks of concern. as well as the ways in which they use the habitat, is key. Although there will be common factors affecting many fish populations, detailed restoration plans should be based on a case by case analysis. Supplementation efforts described in this section are based on restoring anadromous salmonid populations to their historical localities and levels of production in so far as is humanly possible. Natural fish stock rehabilitation activities facilitated by the use of the hatchery system are commonly known in the Columbia Basin as supplementation, although the specific practices envisioned have varied among the proponents. A holistic rehabilitation plan, given the constraints imposed upon the Columbia River Basin fish production system by human activities, requires the effective use of supplementation in conjunction with improved habitat, water quality and flow, and fishery management. Wherever possible. the plan envisions actions to make it possible for anadromous salmonid stocks to be returned to their ancestral habitats through a variety of actions, including supplementation.

\section{Definition of Supplementation}

For the purpose of this document, supplementation is defined as the stocking of fish into the natural habitat to increase the aburdance of naturally reproducing fish populations. Maintaining the long-term genetic fitness of the target population. while keeping the ecological and genetic impacts on nontarget populations within acceptable limits, is inherent in this working definition. This definition is consistent with efforts by other groups, such as the Regional Assessment of Supplementation Programs to define elements of supplementation.

Supplementation includes activities where fish are stocked into barren habitats (historically or currently unoccupied by the target fish population). This activity is commonly referred to in the literature as transplantation or introduction (Withler 1982; Fedorenko and Shepherd 1986). In the Columbia Basin, supplementation activities will, in most cases, involve stocking fish into habitats that contain depressed, but existing natural fish populations. 
A. Life history and biological requirements

LFE CYCLE DIAGRAM (by life stage, biological process, environmental requirements)

.. Upstream migration

.. Pre-spawning

-. Spawning

-. Egg and alevin incubation

.. Fry emergence and migration

.. Juvenile rearing

-. Seaward migration

-. Estuarine residence

-. Ocean rearing and maturation

B. Factors limiting abundance (using Colwmbia Basin sockeye as an ezample)

Blocked access to historical spawning and rearing habitats

-. Chief Joseph Dam on the Columbia River

- Hells Canyon Dam on the Snake River

-. Vaseaux Dam on the Okanogan River

.. Pelton Dam on the Deschutes River

Stream spawning and incubation habitat

.. Low flows

-. Dewatering of redds, icing

-. Amount of spawning gravel

-. Predation

-. Amount of genetic material

Nursery lake rearing habitat

-. Lake productivity

.. Water quality

-. Competition with kokanee and others

-. Predation

Tributary passage

Juveniles: Unscreened irrigation diversions may cause juvenile mortality.

Adults: Low water flows and high water temperatures (above 20 degrees Celsius) during summer and early fall delay entry of adults into the Okanogan River for one to two months.

(continued) 
Table 55

(continued)

Mainstem passage

Juveniles (4.6 weeks duration): $23 \%$ to $39 \%$ total survival

Adults (1.5.3 weeks duration): about $8 \%$ total mortality

Harvest

Harvest favors smaller, less fecund fish

Mixed-stock harvest detrimental to weak Redfish Lake stock

Estuarine survival and growth

Duration of estuarine residence (2-4 weeks)

Estimated survival

Ocean survival, growth and maturity

Duration of residence ( 1 -3 years)

Estimated survival 
Although artificial propagation has a central role in most supplementation activities, the definition of supplementation used here does not preclude the use of fish that have not been reared in a hatchery or other man-made propagation facility. However, unlike many "traditional" hatchery programs, the objective of supplementation is to increase the abundance of a naturally reproducing fish population and therefore, is oriented toward maintaining the natural biological characteristics of the population and reliance on the rearing capabilities of the natural habitat. In contrast, many traditional hatchery programs were designed to augment harvest by the development of hatchery fish populations that rely entirely on artificial spawning and rearing in the hatchery. These hatchery fish populations were not intended to contribute, and most likely have not contributed. to the abundance of naturally spawning fish populations. Typically, the juvenile fish are released into streams adjacent to the hatchery and the returning adults are guided back to the hatchery through the use of barriers and fishways.

The increase in the abundance of a naturally reproducing fish population may be self- sustaining after an initial but finite period of supplementation or it may be sustained through continual assistance from supplementation depending on the specific spawner-recruit relationship under given environmental conditions and management objectives. Supplementation measures will not obviate the need to concurrently pursue other necessary actions such as improvement of mainstem passage, habitat protection, and harvest management to rebuild stocks.

\section{Uses of Supplementation}

Supplementation is considered a tool for rebuilding natural fish populations; not a panacea. It can be used to assist in rebuilding natural stocks, to replace extirpated stocks, or to introduce and establish a stock in a barren habitat (Withler 1982; Fedorenko and Shepherd 1986).

\section{Seeding Barren Habitat}

For barren habitats, which historically produced salmon or steelhead but are currently unoccupied, it is necessary to stock fish into the habitat to reestablish a desired fish population (Table 57). The fish should be stocked at densities that do not exceed the carrying capacity of the habitat for the limiting life history stage being stocked. The carrying capacity of a damaged habitat will need to be re-evaluated as rehabilitation is undertaken. In evaluating carrying capacity, the potential for interspecific interactions and risks to non-candidate species must be addressed. In currently unoccupied habitat, it is essential to choose a fish population that has adaptive traits that are as similar as possible to those of the extirpated population. It is also desirable, but not essential, to match their genotypes if such information is available. 
For "sparsely populated" habitats where there is an existing damaged (Type II.A. Table 57) salmonid population, the objective is to boost the population density above a certain minimum viable population size (MVP) as quickly as possible (Thomas 1990). For example, the minimum viable spawning escapement size for each stock may be calculated from the minimum effective breeding number by a transfer function whose elements include the amount of spawning and rearing habitat available, average total mortality, and average pre-spawning mortality, to mention some of the most important factors. The concept is that getting a seriously damaged population out of danger of extirpation is a suitable role for supplementation.

The primary role of supplementation in this case is to increase the survival rate of the population during its early life history (egg through smolt) relative to its survival rate under natural conditions. It is anticipated that this effort will result in increased adult returns to seed sparsely populated habitats.

For depressed stocks, the question of how many and what proportion of the natural stock to intercept for hatchery brood stock must address the need to maintain an effective breeding number in the natural and hatchery brood stocks. In practice such questions can only be resolved by carefully evaluating the impact of programs that initially take moderate fractions of the depressed population for brood stock (Table 57).

\section{Speed Rebuilding to Carrying Capacity}

For either an undamaged or a rebuilding, lightly damaged stock in healthy habitats (Type III and Type II.C.. Table 57), a potential but unresolved role of supplementation is to increase the rate the population rebuilds. Supplementation may be unnecessary in the long term if other factors limiting populations in the basin are corrected.

\section{When to Use Supplementation}

\section{Life Cycle Analyais of Limiting Factors}

A sound analysis of the population status (such as depressed or healthy). population trend (such as decreasing. stable or increasing, and the factors limiting population abundance is necessary to address the policy question of whether it is appropriate to use supplementation as a tool in increasing natural production. When a stock is considered to be at some high level of risk inon. viable status or declining numbers) and a policy decision is reached on the need to reverse the slide toward extirpation and implement restorative measures. and the 
physical and biological constraints on the natural stock (such as habitat conditions, passage and water quality) make its restoration feasible. supplementation should be considered as a chief form of biological support for the natural population.

An evaluation of the physical and biological constraints on the natural production system might reveal that some measure of stock restoration using supplementation could be achieved immediately without prior corrective actions (such as habitat recovery). However, in cases where, for example, habitat degradation is evident and is likely to rapidly become a limiting factor in the natural population's rebound, habitat protection and restoration should be initiated prior to or at the same time as the supplementation program. All available conservation actions such as reducing passage mortalities, reducing harvest mortalities, and rehabilitating spawning and rearing habitat need to be identified and prioritized to be used singly or in various combinations in concert with a supplementation program. Supplementation measures do not obviate the need to correct other factors limiting stock productivity.

\section{Decisions Regarding the Use of Supplementation}

The potential need and efficacy for use of supplementation depend both upon stock status and management objectives for a particular state as well as potential impacts on other stocks and species. The decision to initiate a new supplementation program or to modify an ongoing program must be determined on a case by case basis. Table 56 presents eight criteria that the fishery agencies and tribes consider in determining whether to initiate or revise a supplementation program.

Once a policy decision has been made to initiate or modify a supplementation program. a number of additional considerations must be addressed to appropriately define the nature of the new or revised program. Table 57 presents guidelines that the fishery agencies and tribes will consider in defining a particular supplementation program.

\section{Prerequisites for Supplementation}

For supplementation to be part of the solution to increase the abundance of natural fish populations, the following prerequisites must also be met.

In reading the text that follows, care must be taken in interpreting terms such as "carrying capacity" and "maximum escapement level." These terms are defined in the context of an undamaged environment in which the various species of anadromous salmonids complete their life cycles. 
The present or rehabilitated habitat should be judged capable of supporting a viable, self-perpetuating population in the face of natural stochastic events (such as floods, droughts. earthquakes), demographic factors (ability to find a mate, sex ratio, age structure) and genetic considerations (such as maintenance of an effective population size to prevent serious loss of genetic variation). This is important to ensure that the carrying capacity of the habitat does not become a limiting factor in the population's rebound.

Salmon need different types of habitat during various stages of their life cycle (Reiser and Bjornn 1979). Sufficient pre-spawning habitats (deep, cool, calm pools) should be available for spring chinook, summer chinook, and summer steelhead adults that have to hold several months before proceeding to their spawning habitat. Adequate spawning habitat should be presently or potentially available. Anadromous salmonid habitat requirements for spawning include sufficient gravel of the right size, suitable water temperatures, flow conditions. and water quality.

Adequate rearing habitat for feeding and growth should be available to support the juveniles produced during the season (spring, summer, fall) that they occupy the habitat. For juveniles that have to overwinter in fresh water. adequate habitat for this purpose must be present. In streams having high juvenile production followed by a large downstream displacement in fall. the lack of sufficient overwinter rearing habitat in downstream areas would negate production increases in headwaters. Thus, an important consideration is a periodic evaluation of habitat suitability and sufficiency on a seasonal and basinwide scale.

\section{A Suitable Stock is Available for Supplementation}

The biological requirements of the stock to be used for supplementation must be carefully matched to the proposed habitat such that survival. growth and reproduction are successful. Thus, it is important to obtain knowledge of the biology. life histories, habitat use, and genetics of candidate stocks insofar as this knowledge is obtainable. Supplementation can involve stocking of fish that descended from the natural population being supplemented or can involve the use of fish that have varying degrees of genetic distance from the supplemented population. In many cases, action on the basis of the best available information will be necessary. To maximize the chances for success, the indigenous stock should serve as the brood stock in its own enhancement program (Table 57. Types II.A.2 and II.C.). If this is not possible (Types I and II.A.1), a stock with the greatest likelihood of being closely related to the potential recipient stock or fish from environments that closely resemble the proposed recipient site should be evaluated as a potential. 
Among important biological traits, spawning, incubation and emergence times (temperature dependent) must be synchronized with favorable environmental conditions such as suitable flows, temperatures, and food availability. To ensure migration success, imprinting of juveniles, migration to the ocean, and subsequent homing as adults to their natal stream must occur (Hasler and Wisby 1951: Jensen and Duncan 1971; Madison et al. 1973: Scholz et al. 1975; Cooper et al. 1976; Cooper and Scholz 1976; Nordeng 1977; Cooper and Hirsch 1982; Hasler and Scholz 1983; Brannon et al. 1984: Slatick et al. 1988). Since adults do not feed during their reproductive migration, they must possess sufficient energy reserves and physical stamina to travel back to their natal stream. Thus, fish from a lower Columbia Basin watershed may successfully imprint and attempt to home to an upper basin watershed, but the migrants may not have the physical stamina and energy to complete their journey.

Appropriate Technology

For supplementation to be successful, the artificial propagation technology must be adequate to rear and release the fish into the habitat in a biologically. genetically and ecologically sound manner. The technology must provide a survival advantage sufficient to bring the spawner-recruit relationship of the combined natural and hatchery-reared segments of the fish population above the replacement level. A life cycle analysis of the components of fecundity and mortality of the fish population both with and without supplementation should be conducted to compare the results under given environmental and management conditions.

\section{Approach to a Supplementation Program}

\section{Phased Implementation and Adaptive Management}

Although the fishery agencies and tribes consider supplementation to have potential as a tool for increasing natural fish production, there is not yet a detailed understanding of which techniques work best under which circumstances. These uncertainties will necessitate undertaking a program of phased. experimentally designed supplementation studies as part of ongoing implementation of the supplementation program. Supplementation should proceed cautiously so that productivity of supplemented stocks can be tested. Past failures have left concerns as to productivity. Procedures and techniques identified in this chapter are intended to improve supplementation practices. These procedures apply the concept of adaptive management, which relies heavily upon monitoring and evaluation. 
Representative pilot sites will be identified for initial supplementation by the process described above and summarized in Table 56. As knowledge and confidence are gained and natural production is increased. supplementation technology will be improved and more sites will be phased in for supplementation.

Within a given project site, the level of supplementation will also be phased in. commensurate with the number of spawners available for brood stock as explained in Table 56. For example, for a site with an estimated capacity of 200.000 juveniles, the level of effort could be increased in quarters: Phase 1.25 percent of target capacity; Phase 2, 50 percent; Phase 3, 75 percent; Phase 4, 100 percent. As experience is gained, succeeding phases will be adjusted or the entire project aborted as warranted.

\section{Moxitoring and Evaluation}

Since supplementation technology is nascent and uncertainties exist in its effectiveness and safety, it is important to incorporate a monitoring and evaluation program to assess performance of each supplementation project. Knowledge and experience gained should be incorporated into the design and operation of future supplementation projects. Kapuscinski and Lannan (1986) describe a conceptual phenotypic model to ensure the long-term reproductive fitness of stocks. Essential elements of monitoring include escapement data by sex and age. estimates of survival at each life stage, and the ability to distinguish supplemented from natural spawners visually, or by some other rapid method that does not harm the animal.

Two levels of monitoring and evaluation are envisioned. The first level is to determine the degree of success of the supplementation project. The second level is to try to answer why the project was successful or not successful and provide ways to adjust the program and to apply the results to guide other proposed supplementation projects. The procedure for monitoring and evaluation should include the following elements.

A) Clearly define supplementation objectives.

B) Identify performance measure(s) for each supplementation objective.

C) Develop experimental and sampling design.

D) Collect and analyze data.

E) Interpret results.

F) Adjust or correct the parts of the supplementation plan that are ineffective or inefficient in meeting the objective(s). Alternatively. modify objective(s) if they 
are unclear, too general, conflicting or too ambitious so that existing plan can achieve them.

G) Review the adequacy of the monitoring and evaluation plan and modify accordingly.

\section{Supplementation Technology}

Previous sections presented a working definition of supplementation, discussed its. potential role in a comprehensive effort to address the physical and biological constraints on natural fish production, and provided general guidelines of when supplementation is appropriate. The following sections discuss some key considerations and general guidelines to provide a logical starting point in crafting the specifics of how to conduct the supplementation program. Each of the following considerations needs to be evaluated and tailored to the specific supplementation program.

\section{Level of Technology}

Since supplementation in the Columbia River Basin will most likely involve some type of artificial propagation, one of the considerations is to determine an appropriate level of technology to a specific situation. Artificial propagation encompasses a wide range of technology from small-scale facilities (such as streamside incubators) located at tributaries to large-scale, centralized hatchery facilities. Thus, it may be useful to consider the availability, advantages and disadvantages of small-scale facilities and large-scale facilities.

Large-Scale Facility

A total of 85 hatcheries and satellite facilities in the Columbia River Basin rear an average of 7.7 million pounds of anadromous fish per year (Delarm and Smith 1990). One approach is to consider whether some of these existing hatchery facilities, with some modifications, would be appropriate to use in a supplementation program since these facilities are already in place and operational.

In general, some key changes would have to be made for some of these facilities to be used in supplementation. It is envisioned that incubation and rearing will continue to be done in the central hatchery. However, if two or more stocks will be reared in the hatchery, provisions must be made to keep them separate. Moreover, to ensure genetic compatibility, hatchery brood stock should be collected from the natural population targeted for supplementation. Thus. provisions must be made to collect adults at or near their home stream. Also. juvenile acclimation facilities should be considered for the purpose of allowing the 
fish to imprint and adjust gradually. to the natural environment before their eventual release into their home stream.

An example that applies this approach is the East Bank central hatchery facility located near Rocky Reach Dam in the Columbia River (Rock Island Project Settlement Agreement). The central hatchery was designed with incubation and juvenile rearing facilities, but no facilities for on-site adult collection and release of juvenile fish. Instead. satellite facilities located near the streams targeted for supplementation were designed for brood stock collection and juvenile acclimation and release.

The potential advantages of using the large-scale approach must be weighed against some potential disadvantages. Large-scale hatcheries literally put all one's eggs in one basket with all that is implied about risk taking (Larkin 1981). Should there be a failure, human error or accident in the hatchery, large numbers of fish may be lost. The fish will not be reared in the same water into which they will be released except for the final period before release when acclimation ponds are used. Thus, imprinting may not be as complete and unequivocal. This approach may also entail more handling and transporting of adult fish from the supplemented streams to the hatchery and juvenile fish from the hatchery to the supplemented streams. Thus, there is a greater potential for stress, health impairment, fish mortality, and straying.

\section{Small-Scale Facility}

Another approach envisions the use of small-scale facilities that are located alongside the streams targeted for supplementation. The size of these facilities are relatively small (600 to 10.000 pounds of juveniles) and would depend on the capacity of the streams targeted for supplementation. Adult collection and juvenile release facilities would be located on site thus eliminating or greatly reducing fish handling and transportation. which may lead to stress, impaired health and mortality. This approach would include incubation and rearing facilities located on site and would use the stream water for its water supply. Since the fish would be reared using the same water where they would be released throughout their residence in the hatchery, acclimation facilities would not be necessary and imprinting of juveniles should be more complete and unequivocal. This, in turn. should improve adult homing back to the stream and reduce straying.

The use of small-scale facilities allows for considerable flexibility in managing many smaller units. so that when deemed appropriate. a project can be abandoned with limited potential ecological damage and loss in investment. Smaller releases of juveniles commensurate with the capacity of the stream should reduce potential effects from "ecological swamping." This approach is readily adaptable to individual drainages. enabling the conservation of gene pools. 
Because the fish would rear in artificial conditions more similar to their natural environment, artificial selection should be reduced.

The disadvantages with the small-scale hatchery approach include potentially greater cost in constructing and operating many small facilities located in the tributary streams. Logistics in manning many scattered facilities may also prove difficult. Moreover, some of these potential sites may not be readily accessible (no roads).

Most of the sites in the Columbia River Basin containing large quantities of water required by large hatcheries $(100,000$ pounds of fish or more capacity) have already been developed (Senn et al. 1984). However, there are many potential sites still available for developing small-scale hatcheries to produce smaller quantities of fish.

An example of this approach is the streamside chinook salmon spawning and rearing facility of the U.S. Forest Service at Horse Linto Creek, a tributary to the Trinity River in northern California. The facility consists of an adult migrant trap, two hatch boxes, a filter system, two fiberglass raceways, and an earthen rearing pond. The adult migrant trap and the juvenile release facility are located on site and adjacent to the stream. This arrangement minimizes fish handling and transportation. Juvenile releases from the facility started with 5,000 fish in 1984 and has increased to 57,000 in 1989. Before the restoration project began, less than 10 spawning pairs were counted $(1979-1981)$ in a 2.5 mile index. By 1988 and 1989, the number of spawning pairs counted had increased to 50 and 55 respectively. Forest Service biologists are confident that the project can rebuild the chinook population to the estimated stream capacity.

This small-scale approach was used by Sweden in a program to preserve native runs of Atlantic salmon in tributaries to the Baltic Sea after they were blocked by dams (Behnke 1986). Instead of constructing a few large centralized hatcheries. Sweden opted for constructing a smaller hatchery (17 in all) in each major river. This approach was chosen to propagate the native runs of each river and to preserve the original genetic diversity. The smolt-to-adult survival rates have typically ranged from 10 percent to 20 percent.

\section{Spawning Protocol}

The goal is to conserve genetic resources and maintain the ability of the stock to survive and reproduce in the natural environment. Relevant brood stock management principles and spawning guidelines (Hershberger and Iwamoto 1981: Kreuger et al. 1981; Kincaid 1983; Seidel 1983; Tave 1986) should be carefully considered. Special considerations will be necessary to supplement remnant (endangered or threatened) wild stocks (Meffe 1986. Kapuscinski and Phillip 1988). The main points of these guidelines include: 
A) Maintenance of a large effective breeding size (Ne) for each generation to minimize inbreeding and genetic drift. To protect against inbreeding depression, the following information is required: the level of inbreeding at which inbreeding depression occurs and the number of generations you wish to incorporate in a breeding program before inbreeding reaches the critical value. For example, an Ne of 250 would keep the level of inbreeding below 10 percent through 50 generations (Tave 1986). To guard against genetic drift, the following information is required: how valuable are the rare alleles (how rare an allele would you try to save), and the desired probability level of saving rare alleles through the course of a given number of generations. For example, an Ne of 424 would provide a 99 percent probability of saving a rare allele with a frequency of 0.01 through 50 generations.

B) Insurance that the brood stock selected is representative of the natural population targeted for supplementation. To achieve this objective, a large sample size should be selected at random from the entire spectrum of the fish population (over all age groups and sizes and over the entire spawning season).

C) Implementation of a "no selection" protocol (Tave 1986). For example. fish with poor secondary sexual characteristics. slow growth. etc. will not be culled out. This is designed to conserve the gene pool and ensure survival and reproduction in the wild.

D) Use of equal number of males and females as much as possible or at least keep the sex ratio within 60:40 to 40:60. This is designed to maintain a high Ne.

E) Monitoring of the wild and hatchery-reared fish for genetic and phenotypic information.

F) Consideration of the ratio of wild/natural to hatchery spawners in the natural habitat that minimizes potential genetic risks to the wild/natural spawners.

G) Consideration of the proportion of wild/natural fish used as hatchery brood stock to maintain the genetic integrity of the wild/natural stock and minimize adaptation to the hatchery.

\section{Rearing Protocol}

The basic approach is to provide more natural rearing conditions to promote the success of the fish after release to the natural environment. The objective is to mimic important natural rearing conditions (such as temperature) as much as possible except for providing a more abundant food supply and eliminating predation. Thus, the use of rearing units (earthen ponds and raceways) that provide more natural rearing conditions should be considered. 
Stocking densities should more closely mimic densities in the stream at full seeding. Crowding should be reduced to help prevent stress, disease outbreaks. and disruption of territorial and other behaviors that are adaptive in the natural environment. Should territorial behavior be disrupted, it may be possible to restore it by conditioning the fish for two to four weeks before release (Shustov et al. 1980).

Hatchery-reared fish can exhibit diminished behavior to avoid predation in the natural environment (Bams 1967: Mead and Woodall 1968) and consequently result in increased mortality (MacCrimmon 1954; Piggins 1959; Kanid'yev 1966; Larsson 1985). To improve the chances of escaping predators after the fish are released, the use of predator avoidance conditioning is very promising (Thompson 1966; Kanayama 1968; Olla and Davis 1989).

\section{Disease Prevention}

Disease prevention must be emphasized. For many diseases, the causative agent is almost always present in the fish's environment. Despite the presence of the pathogen, as long as the environment is not stressful to the fish. disease outbreaks are unlikely (Wood 1974; Meyer et al. 1983). Disease prevention is based on the proper understanding and management of the interactions between the pathogen, the host, and the environment (Sniezko 1973, 1974; Wedemeyer et al. 1977; Meyer et al. 1983; Rohovec 1988, 1990). Primary attention must be given to the role of the environment in increasing the disease resistance of the fish and decreasing the virulence of the pathogen (minimizing crowding, handling, and stress; providing proper nutrition and water quality; and providing proper hygiene and sanitation).

\section{Release Strategy}

Level of Seeding

Sufficient numbers of fish should be stocked and matched to the biological productivity of the habitat to ensure an adequate level of seeding. As the natural stock rebuilds to higher seeding levels, higher egg-to-smolt mortality is expected due to density dependence (Major and Mighell 1969: Bjornn 1978; Jonasson and Lindsay 1983; Knox et al. 1984). However, the total number of smolts produced should increase at higher seeding levels up to the carrying capacity of the habitat.

Life Stage to Stock

There are at least two considerations that would affect the choice of life stage to outplant. First, we want to ensure that successful imprinting to the distinctive chemical cues in the habitat and subsequent homing occur. The 
existence of a "sensitive" period for olfactory imprinting (SPOI) in early ontogeny in Atlantic salmon has been demonstrated (Morin et al. 1989). In salmonid species that undergo smoltification (Hoar 1988). the SPOI appears to correspond to the smoltification period (Cooper and Hirsch 1982: Hasler and Scholz 1983; Smith 1985; Hara 1986). The SPOI was evident between three to four weeks after the onset of smoltification (the total smoltification period was eight weeks) in Atlantic salmon (Morin et al. 1989). During SPOI, the fish's capacity to store information in memory is optimal, implying that some of this capacity may persist beyond the sensitive period.

Second, we want to increase the survival rates for the hatchery-reared fish (during the time period from the egg stage through the smolt stage) compared to the corresponding survival rates typical of these life stages in the natural environment.

Stocking adults or eggs should provide better imprinting to the stream compared to stocking fry and smolts. However, stocking adults or eggs would not provide a survival advantage. Most of the mortality in the time period from the egg stage through the smolt stage occurs after the fish emerges from the gravel. For example. fry-to-smolt survival rates are of the order of 20 percent for spring chinook and 1.5 percent to 3.8 percent for steelhead in Big Springs Creek. Idaho; 2.2 percent to 6.7 percent for steelhead in Snow Creek, Washington; 5.7 percent for coho in Speelyai Creek, Washington; and 7.7 percent for coho in White Salmon River, Washington (Smith et al. 1985). In comparison, egg-to-emergent fry survival rates using streamside incubators in Oregon were of the order of 73.5 percent to 88.5 percent for spring chinook. 79.3 percent to 89.4 percent for fall chinook, 85.6 percent to 93 percent for summer steelhead, about 89 percent for winter steelhead, and 78 percent to 83.1 percent for coho (Smith et al. 1985). Rearing the fish in the same water as the stream where they would be released (the small-scale approach) would allow the flexibility of releasing the fish at any life stage while providing for imprinting.

Size and Age of Fish at Release

It is recommended that fish be released at a size and age that is compatible with those of the natural fish being supplemented to minimize potential adverse ecological interactions (such as predation between the hatchery fish and the natural fish, unequal competitive advantage) and alteration of the age composition of returming adults (increased jack retums with release of larger juveniles). To accomplish this objective, the two primary factors affecting growth. temperature and ration levels should reference natural rearing conditions. Since reduced rations or starvation have adverse consequences on an actively growing fish (Ivlev 1961: Rondorf et al. 1985), primary attention should be directed at mimicking the natural water temperature in the stream. 
Acclimation is a technique used to prepare fish for release in the natural habitat. It is used to provide the fish time to adjust gradually to the natural stream conditions and reduce transportation-induced stress. This is important when fish are not reared in the same kind of water they would be released in. In contrast, acclimation would not be necessary when the small-scale approach is used because the fish would be reared in the same water as the receiving stream. Care must be exercised to minimize stress from physical handling, confinement of large numbers of fish in small containers, and sudden changes in water quality parameters (such as temperature) when the fish are transferred from one water to another. Such stress can lead to mortality and can also impair a fish's ability to learn for up to several weeks (Sandoval 1979; Olla and Davis 1989). This could block imprinting processes needed for subsequent adult homing.

Timing of Release

Timing of release of juveniles into the natural habitat from hatcheries is a major determinant of survival success. This timing involves the coincidence of various biologic factors (fish size, readiness of fish to migrate and adapt to ocean conditions, outmigration of other hatchery and natural stocks, and estuarine and marine conditions such as food availability, predator abundance, competition for food from other fish stocks) and physical factors (migration conditions such as flows, operation of mainstem dams, mainstem and tributary water temperature patterns, and estuarine and marine conditions such as temperature and upwelling. Volitional release (allowing the fish to exit the rearing facility when they want to) is favored over forced release. Releasing fish at the proper time of day can also reduce initial predation losses and facilitate the adaptation of the fish to a new environment.

\section{Dispersal}

Past supplementation programs commonly released the fish at a single point in the stream (Steward and Bjomn 1990). This practice may lead to limited dispersal and poor utilization of the habitat. The relative effectiveness of scattered and point releases should be considered in a supplementation program.

\section{Risk Analysis}

This section will address only the potential risks of the kind of supplementation as proposed in this chapter, not any other kind of supplementation or hatchery program. 


\section{Risk of Extirpation or Reduction of Natural Stock}

No Action

The risk of contributing toward the further decline of a fish population through the use of supplementation must be weighed against the risk of continued decline and eventual extirpation when no action, of any kind, is taken to restore the population.

Partial or Total Failure in the Hatchery

Possible loss of a significant portion of the natural stock through partial or complete failure in the hatchery (loss of electric power, pump failure. loss of rearing water through leakage. human error and accidents) is a risk that must be minimized. Efforts to reduce this risk include building fail-safe features in critical hatchery components, reducing the proportion of natural fish that are brought into the hatchery, rearing the fish in two or more facilities to avoid the risk of failure at one facility, and the use of small-scale facilities.

\section{Predation}

Increased or decreased predation on wild fish may occur due to large pointsource stocking of hatchery-reared fish in the stream (Steward and Bjornn 1990). To minimize the impact of predators on young salmon, it would be necessary to understand which predators are present and their capability to consume salmon prey. Different predators respond differently to increased prey abundance. Birds have been shown to have a nonlinear and depensatory functional response (Mace 1983), whereas predator fish can be compensatory at low prey densities, but depensatory at higher densities (Peterman 1987). This risk can be minimized by avoiding large point-source releases. Instead, the stocked fish should be dispersed throughout the target stream area. In addition, since we are attempting to restore the natural population to historic levels. an increase in predation should be no more than what the population sustained when it was at abundant levels.

Another concern is the potential predation between the stocked fish and the supplemented natural fish. If there are significant size differences, predation between hatchery-reared fish and the supplemented fish cannot be ruled out. Thus, this risk can be avoided by stocking fish at a size consistent with that of the natural fish.

\section{Competition}

Competition for food and space between the natural fish being supplemented and the stocked fish is influenced by the capacity of avaldable rearing habitat. There a paucity of information on the potential competution 
between the supplemented salmon population and other fish populations inhabiting the target stream (Steward and Bjornn 1990). Since the goal is to restore the natural population to historic levels commensurate with the carrying capacity of the habitat, the adverse effects of competition should be no more than that experienced by the population when it was at higher abundance levels. The supplementation strategies described in this chapter seek to minimize or eliminate any differences between the stocked fish and the wild fish so that they are a single population.

\section{Disease}

Not much is known about the role of disease in natural fish populations. There is little evidence that hatchery-reared fish cause widespread transmission of disease to natural fish (Steward and Bjornn 1990). Fish can carry pathogens and not show any outward signs of the disease. As a consequence, subclinically infected fish are probably released into natural waters more often than is realized (Marnell 1986). In any case, it is desirable to avoid introduction of pathogens and disease from the potential stock to the supplemented stock. This precaution includes introduction of exotic pathogens and also endemic ones that present a threat to the healthy naturally spawning population.

\section{Loss of Genetic Variability Between Populations}

Hybridization between different populations typically increases gene diversity (heterozygosity) within the hybridizing populations at the expense of a loss of gene diversity between populations. The concern is that a variety of locally adapted populations will be replaced with a smaller number of relatively homogeneous populations (Allendorf and Leary 1988). This consolidation will tend to limit the potential of the species to adapt to new environmental conditions and reduce its capacity to buffer total productivity of the resource against periodic or unpredictable changes (Riggs 1990).

Outbreeding Depression

Outbreeding is the mating of unrelated or distantly related individuals. The potential for outbreeding depression. specifically when hatchery fish mate with wild fish, is a concern related to supplementation in the Columbia Basin. Depending on the specific mating and on the genetic distance between the hatchery and wild fish. the hybrids may display increased (heterosis or hybrid vigor) or decreased (outbreeding depression) fitness (Waples in press). Heterosis is more likely when the hybridizing gene pools are inbred and not too different genetically. As genetic distance between the parental stocks increases, however. genetic incompatibilities become more likely and the fitness of the hybrids may decline (outbreeding depression). Current genetic theory on hybridization theorizes that the potential effects of hybridization results from genetic variance 
due to the interactions among alleles (Tave 1986). Because this form of genetic variance depends on interactions, it is disrupted during meiosis and cannot be transmitted from parent to offspring. This genetic variance is created anew and in different combinations each generation and its effects are basically those based on chance.

A few studies have indicated the potential for outbreeding depression when hatchery fish are mated with wild fish. These studies did not look at outbreeding depression per se, but rather compared the performance of hatchery fish with wild fish in the natural environment.

A study in the Deschutes River in Oregon compared the progeny from hatchery reared for several generations, wild, and hatchery-wild parents in the natural environment (Reisenbichler and Mclntyre 1977). The authors concluded that wild eggs survived better than hatchery-wild eggs and hatchery eggs. Juvenile fish also differed among the treatments. Hybrid juveniles were larger than the non-hybrid juveniles. This suggests that there were differences between the hatchery fish and the wild stocks.

In a study in Washington. the reproductive success of a Skamania Hatchery steelhead stock was compared with the reproductive success of wild Kalama River steelhead stock in the natural environment of the Kalama River (Chilcote et al. 1986). The success of hatchery fish in producing smolt offspring was only 28 percent of that for wild fish. The failure of the hatchery fish to produce as many offspring as the wild fish can be attributed to the use of a hatchery stock that was maladapted to the natural environment of the Kalama River. The Skamania Hatchery stock originated from wild stock indigenous to the Klickitat and Washougal rivers (a different drainage) and has been subjected to artificial selection for hatchery production traits for many years (Leider et al. 1990). The hatchery fish were subjected to more unfavorable flooding conditions in the Kalama River since they spawned earlier than the indigenous wild fish.

The effectiveness of using hatchery fish to rebuild wild populations was evaluated in 15 supplemented and 15 control streams in the Oregon coast (Nickelson et al. 1986; Solazis et al. 1990). Although the summer density of hatchery and wild juveniles increased in the supplemented streams, the density of only the wild juveniles was reduced. Adult returns to the supplemented streams were not significantly different from returns to the control streams and the hatchery fish produced juveniles at a lower rate than wild fish. The failure of this program can be attributed to the use of a hatchery stock that was incompatible with the wild population and maladapted to the natural environment. The hatchery fish were subjected to more unfavorable freshet conditions because they spawned earlier than the wild fish. Also. the hatchery fish outcompeted the wild fish since they were released at a much larger size than the wild fish. 
All these studies indicate the fundamental importance of selecting a stock that is compatible with the target stock and adapted to the target stream environment. Since the level of outbreeding that causes outbreeding depression is not known, it is impossible to predict whether a particular hatchery and wild cross will result in outbreęding depression. In addition, the variable (hatchery fish) being tested is quite undefined and imprecise, which results in a variety of effects given the same variable. Hatchery fish are spawned, incubated, and reared in many different hatchery environments using many different hatchery practices. A comparison between hatchery fish and wild fish lumps too many complicating factors that cannot be separated from each other. Thus, it is not known exactly what is being tested.

There is no clear evidence that a well-managed supplementation program. as described here, would pose a serious genetic risk to the natural population through outbreeding depression. The supplementation program described here attempts to eliminate or minimize any serious divergence between the hatchery brood stock and the target stock by ensuring that the hatchery brood stock is representative of the natural stock and by minimizing divergent natural selection by minimizing important differences between the hatchery and wild environments.

\section{Loss of Genetic Variability Within Populations}

\section{Inbreeding Depression}

Inbreeding is the mating of related individuals (Tave 1986). Genetically, all inbreeding does is increase the homozygotes at the expense of the heterozygotes. Since almost every organism carries deleterious recessive alleles that are hidden in the heterozygous state, increasing homozygosity increases the likelihood that deleterious recessive alleles will be paired and expressed. The pairing of detrimental recessive alleles produces a general trend toward lowered viability. survival, growth, egg production and increased abnormalities (Ryman and Stahl 1980; Allendorf and Phelps 1980; Gall 1983; Allendorf and Ryman 1987). This phenomenon is called inbreeding depression.

To protect against inbreeding depression, a basic approach is to maintain a large, effective population size (Ne). To calculate the Ne that is needed to prevent inbreeding from reaching levels that decrease productivity, two pieces of information are required: the critical level of inbreeding at which inbreeding depression occurs, and the number of generations to incorporate in a breeding program before inbreeding reaches the critical level (Tave 1986). For example. an $\mathrm{Ne}$ of 250 fish would keep the level of inbreeding below 10 percent through 50 generations.

Thus, an integrated approach. to guard against both outbreeding and inbreeding depressions, must travel the middle road. If we move too far to one 
side (mating closely related individuals) we risk falling into the inbreeding depression ditch. If we more too far to the opposite side (mating distantly related individuals) we risk falling into the outbreeding depression ditch.

\section{Genetic Drift}

Genetic drift refers to random changes in gene frequency caused by sampling error between generations (Tave 1986). The effect of genetic drift is the loss of some alleles and the fixation of others (inbreeding). Rare alleles are easily lost. but more common alleles can also be lost via genetic drift. The loss of alleles (reduction in genetic variability) will limit the potential of a population to adapt to changes in environmental conditions and compromise its ability to exploit new environments.

A narrow genetic variability in a fish population would not necessarily result in low productivity or fitness to a particular environment. It would depend on the degree of adaptation of the population to the given environment and the magnitude and rate of change in the environment. Introduced chinook, coho, and pink salmon in the Great Lakes are examples of fish populations that were initiated from very small founding populations. Despite this narrow genetic variability, these fish have been thriving well for the past 20 to 40 years (Tanner 1988). Moreover, many species and populations of organisms used for biomedical research are purposely bred to minimize genetic variability so that all individuals will respond in a similar manner to experimental variables.

To guard against genetic drift, the basic approach is to maintain a large Ne. The Ne that is needed depends on the following pieces of information: how rare an allele would you try to save and the desired probability level of saving rare alleles through the course of a given number of generations. For example, an Ne of 424 fish would provide a 99 percent probability of saving a rare allele with a frequency of 0.01 through 50 generations.

Selection

Anadromous salmonids are reared in a hatchery environment for only a portion of their life cycle. For the majority of their life cycle, hatchery fish are exposed to the same natural environment and subjected to the same natural selection process as wild fish. However, this does not mean that the selection (artificial and natural) that may occur in the hatchery is not important as far as the ability of the fish to survive and reproduce successfully in the natural environment.

Artificial selection in the hatchery may select for hatchery production traits that are not adapted to the natural environment. For example, brood stock may be selected from only the early part of the run because the egg-take quota has 
been filled or to produce fish that are larger at release or can be released earlier. Only large spawners or spawners that are ripe, when the hatchery manager wants to spawn fish, may be spawned. Also, throughout the rearing period slow-growing fish may be culled out.

Moreover, the natural selection process that occurs in the hatchery is most likely different from that which occurs in the wild by virtue of the difference between the hatchery and wild environments. Egg-to-smolt survival rates are typically 5 percent to 15 percent in the natural environment while the corresponding rates under artificial propagation are about 60 percent to 80 percent (Howell et al. 1985). This difference represents a reduced intensity of selection that occurs in the wild (most of the fish that would have died in the wild survive in the hatchery). Conversely, a higher percentage of wild smolts may typically survive to return as adults than hatchery smolts. The high post-release mortality for hatchery fish allows ample opportunity for selection against traits that are adapted for hatchery conditions, but not in the wild, thus counteracting, to some extent, adaptation to the hatchery environment. Thus, the degree to which the hatchery fish would diverge from the wild fish will depend on the degree that the wild smolts are genetically representative of the hatchery smolts.

The supplementation scheme described in this chapter seeks to eliminate any divergence between the hatchery fish and the wild fish by using representative samples of the wild population as hatchery brood stock, by avoiding any artificial selection, and by minimizing the difference between the natural and the hatchery environments. Although one can hypothesize that exposure to the hatchery environment, for even a small portion of the fish's life cycle, allows some genetic divergence from the natural genome, the degree and consequences of the change remain unknown.

\section{Hatchery versus Natural Environment}

The kind of supplementation described in this chapter is based on the underlying principle that the fish population must be adapted to its environment to thrive. Since genetic fitness is a function of the environment, it is important to evaluate the hatchery environment vis à vis the natural environment with respect to those parameters that are related to performance and genetic fitness traits. A complicating factor that must be taken into account is that the natural environment and, to a lesser extent, the hatchery environment changes daily, seasonally, and from year to year. In general, the quantity and diversity of salmonid habitats in the Columbia Basin have been greatly reduced (NPPC 1986). For example, over one-third of the spawning and rearing habitat has been eliminated by impassable dams. Thus, any program of supplementation that emphasizes restoration of natural stocks and maintenance of their genetic diversity must be accompanied by an equal emphasis on restoration of habitat quality and quantity to which these stocks have adapted. 
The genetic concern associated with supplementation must not preclude needed attention on other equally important genetic risks associated with habitat loss and degradation, alteration of the migrational environment, and harvest. Habitat loss and degradation can affect the genetics of wild populations by depressing the Ne of the population and by natural selection for increased fitness in the new environment, which may decrease the value of the resource (Kapuscinski and Jacobson 1987). Harvest management can affect the genetics of wild fish in at least two ways (Kapuscinski and Jacobson 1987). First. high exploitation rates can reduce the $\mathrm{Ne}$ of a stock so that rates of genetic drift and inbreeding are increased. Second, fishing methods and regulations can act as artificial selection programs that can cause genetic change in the stock over time (Handford et al. 1977; Favro et al. 1979; Ricker

1981). The migrational environment of Columbia Basin anadromous salmonids have been drastically transformed from fast flowing streams to slowmoving reservoirs. Flow allocations and spill favor juvenile fish whose outmigration timing coincides with the flow.

\section{Research Needs}

A) How different is a hatchery-reared fish population from its wild counterparts in terms of important performance traits, such as survival, growth, reproduction. migration? How are these traits affected by the hatchery environment and by the natural environment? Harsher natural environment compared to hatchery environment?

B) In a natural fish population. which genotypes and gene frequencies comprise the typical 5 percent to 15 percent of the fish eggs that survive to smolt stage in the natural environment? Do the survivors represent a random sample of the total eggs deposited or are they a result of natural selection in the wild?

C) In a hatchery-reared fish population, which genotypes and gene frequencies comprise the typical 60 percent to 80 percent of the fish eggs that survive to smolt stage in the hatchery environment? Do the survivors represent a random sample of the total eggs spawned or are they a result of natural selection in the hatchery?

D) Assuming that the fish spawned in a hatchery were derived from and are genetically representative of a given wild fish population, are the hatchery smolts that survive in the hatchery environment genetically similar to the wild smolts from the same wild fish population that survive in the natural environment? 
E) What is the level of inbreeding that causes inbreeding depression? How do we measure inbreeding? How do we measure inbreeding depression? Is there a qualitative aspect to inbreeding (one population with the same level of inbreeding as another population will exhibit inbreeding depression whereas the other will not)?

F) What is the level of outbreeding that causes outbreeding depression? How do we measure outbreeding? How do we measure outbreeding depression? Is there a qualitative aspect to level of outbreeding (one population with the same level of outbreeding as another population will exhibit outbreeding depression whereas the other will not)?

G) Does natural selection reduce genetic variability within a population; between populations?

H) What are the most effective means of ensuring no artificial selection in hatcheries?

I) What are we doing in the hatchery that renders fish less fit when released into the natural environment? Does the hatchery environment influence the expression of traits or behaviors that are not adaptive in the wild environment? For example, hatchery reared fish are not exposed to predators nor provided natural food. Hence, many fish that would have died in the wild due to predation or starvation survive in the hatchery. In the wild, the juveniles learn to avoid predators and learn to capture prey, but in the process incur mortalities through predation and starvation.

J) Evaluate food availability during different life stages in terms of survival, growth, reproduction (growth phases: early rearing in fresh water, estuary, ocean).

K) Compare levels and variability in important parameters (such as temperature) in natural stream environments with those in hatchery environments. Look at temporal variability (diel, seasonal, interannual) and spatial variability (location of hatchery or stream. locations within hatchery or stream - pools, riffles, different reaches). Is there more seasonal variability in a given location than between locations (streams) for a given season? A hatchery has more constant environmental conditions, such as temperature and flow. Compare limited live prey versus abundant pellet feeds, exposure to predation versus little to no exposure, and low stocking density versus high stocking density and its effects on territoriality. 
The criteria for determining the appropriate level of intervention are population abundance and the rate of change in population abundance. The following conditions and constraints are placed on the application of the guidelines.

1) In all cases monitoring and evaluation should be conducted to determine survival by life history stage, and escapement by age and sex.

2) All other appropriate remedies, such as improve fish passage and habitat improvernents, have been identified and have been or simultaneously are being successfully pursued.

3) The actual numbers of fish that constitute a) minimum viable population size. b) proportions withdrawn for brood stock. and c) carrying capacity of the environment would have to be determined on a case by case basis.

4) Little or no data on sex composition of spawning escapements for naturally spawning stocks are available, so that a priori calculation of effective breeding numbers would not be possible.

5) Care would be taken that the selection of rearing water not interfere with the ability of stocked fish to return home to the point where they were released.

6) When data permit, the average spawning escapement is to be based on a period of years equal to three times the age class that represents the largest proportion of the run.

7) Careful evaluation of the status of the stock. its habitat and the need for alternative strategies would occur when the average return of spawners exceeds minimum viable population (MVP) for three generations.

8) Acceptance of these guidelines would not to be construed as limiting the ability or resolve of an agency to meet its statutory responsibilities under federal and state law. 
Guidelines for Supplementation Actions

Appropriate to Various Levels and Rates

of Change in Population Size for Anadromous Salmonids

Summary of Guideline -- (where stock size $=\mathrm{N}$; carrying capacity $=\mathrm{K}$; minimum viable population $=$ MVP)

\section{Estirpated Stock: IN near zero}

I. Damaged Stock:
A. Badly: $\mathrm{N} \ll \mathrm{MVP}<\mathrm{K}$
B. Moderately: $\mathbf{M V P}<\mathbf{N}<\mathrm{K}$
C. Lightly: $0.5 \mathrm{~K}<\mathrm{N}<0.85 \mathrm{~K}$

III. Undamaged Stock: N $>0.85 K>$ MVP

I. Extipated Stock: Average spawning escapement is effectively zero.

A. Stock in the most effective manner with the best available genotypic, phenotypic and ecotypic stock.

B. Emphasize the use of returning adults for brood stock while allowing for escapement to the original spawning grounds.

C. Cease stocking when average return of spawners exceeds the lesser of the minimum viable population size, MVP. (see Thomas 1990) or 85 percent of carrying capacity for three generations. If successful after one or two generations, stocking can be reduced.

\section{Damaged Stock:}

A. Badly damaged; average spawning escapements fall far below MVP and are below the number of adults needed to produce 50 percent of the carrying capacity of the freshwater environment for the limiting life history stage.

1. Decreasing; the trend in average spawning escapements is declining or indeterminate for three life cycles.

(continued) 
Take as few spawners as necessary to cross with the best available genotypic, phenotypic and ecotypic stock. Preserving unique characteristics of damaged stock is an important concern, so the ratio of donor to damaged stock should be around $1: 1$ in parental generations. leaving at least 50 percent $F 1$ to spawn naturally, if survivals permit. Use the other returnees for brood stock in a 1:1 ratio with the same donor stock to continue supplementation. The specific breeding protocol must be worked out with the advice of a professional geneticist on a case-by. case basis. Return (supplement) all production to the habitat from which the damaged stock was taken at an appropriate life history stage.

2. Stable or increasing; the trend in average spawning escapements stable or increasing for three life cycles.

a) Various proportions of native stock up to 50 percent may be taken for brood stock in the breeding program designed with the advice of a professional geneticist. All progeny will be returned to the stream from which brood stock was taken.

b) As supplementation continues, use varying proportions of hatchery. reared and natural returns for brood stock for both artificial rearing and natural spawning in a professionally designed breeding program.

B. Carrying capacity of the freshwater environment for the limiting life history stage.

1. Decreasing; the trend in average spawning escapements is declining or indeterminate for three life cycles.

a) As a first approximation, annually take no more than 25 percent of natural spawners over a period of two life cycles to produce offspring that are reared in isolation and returned to the spawning habitat of their parents.

b) After evaluating one life cycle of returns, if the average rate of returns of artificially reared fish is equal to or better than returns from natural spawners, increase the percentage of natural spawners taken to no more than 50 percent, taking no artificially reared fish for brood stock. If the returns are not better than returns from natural spawners continue at the 25 percent level.

2. Stable or increasing; the trend in average spawning escapements is stable or increasing for three life cycles.

(continued) 
a) Supplementation is a lower priority than cases indicated above.

b) Monitor survival and age-sex structured escapements and if population begins decreasing over one life cycle proceed as in II.B.1.

C. Lightly Damaged; average spawning escapement levels fall between the number of adults needed to produce 50 percent and 85 percent of the carrying capacity of the freshwater environment for the limiting freshwater life history stage.

1. Decreasing; the trend in average spawning escapements is declining or indeterminate for three life cycles.

a) Monitor survival and age-sex structured escapements while determining the trend in escapements, and/or the proximate cause of decline.

b) If stock is actually decreasing after one life cycle;

i. other remedies being available, apply them until the escapements increase for one life cycle.

ii. if the escapements continue to decline after two life cycles, if the average population levels fall below 50 percent of the carrying capacity, or if other remedies are not available, then evaluate the need for supplementation and make a decision whether to proceed as in II.B.

2. Stable or increasing; the trend in average spawning escapements is stable or increasing for three life cycles.

No supplementation action is necessary, but careful monitoring of escapements and survivals is essential.

\section{Undamaged Stock:}

No supplementation is necessary to achieve basic conservation purposes when average escapement deficits are within 0 percent to 15 percent of the maximum in undamaged habitat. Such population levels still require monitoring to evaluate survival and to obtain age and sex structured escapements. 


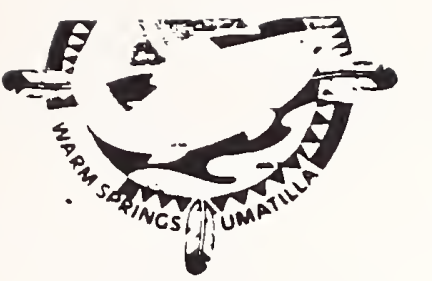

\section{COLUMBIA RIVER INTER-TRIBAL}

729 N.E. Oregon. Suite 200. Portland. Oregon 97232

January 30,1992
FISH

Telephone (503) 238-066; Fax (503) $235.422 \varepsilon$

Ted Hallock, Chaiman

Northwest Power Planning Council

851 S.W. Sixth Ave., Suite 1100

Portland, OR 97204

Dear Mr. Hallock,

The Columbia River Inter-Tribal Eish Commision has been directed by the Commission tribes to submit on their behalf a limited number of high priority experimental supplementation projects. These projects are in response to the supplementation coordination measure described on page 75 of the Power Council's December 11, 1991, Amendments to the Columbia River Basin Fish and Wildlife Program (Phase Two).

The projects are intended to examine a number of critical uncertainties such as size of release, time of release, rearing protocols, and broodstock acquisition. These projects for the most part will rely upon existing rearing facilities and include studies for spring chinook, sumer chinook, fall chinook, and coho.

The Commission and the tribes are prepared to work with the Council and any others you may deem necessary to move the projects to the implementation stage.

Thank you for your assistance.

sincerely,<smiles>CC(C)(O)C1CC1(C)C</smiles>

Ted Strong

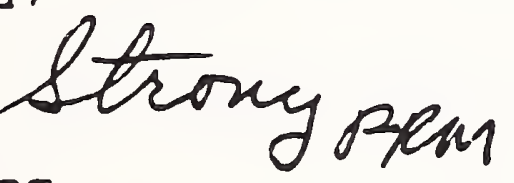

Executive Director

cc: Tribal Biologists

HDE

HDW

ODEW

IDEG

NMFS

FWS

REC.FIVED

FEB 49992 
Tribal Priority Supplementation Projects

\section{Spring Chisook Salmon}

Entiat River - Located in mid-Columbia near Wenatchee, Washington Acquire broodstock from existing natural run

Utilize Entiat National Fish Hatchery for rearing to fed fry and yearling size

Modify existing spawning channel for semi-natural rearing with late fall release

Utilize acclimation facility(ies) for yearling release

Monitor and evaluate using guidelines developed in Chapter C of the Integrated System Plan

Lost River - Located in mid-Columbia near Winthrop, Washington

Acquire broodstock from existing natural sun

Alternative broodstock from Methow River sun

Utilize Methow Valley Spring Chinook Hatchery or Winthrop National Fish Hatchery for rearing to yearling size

Utilize acclimation facility(ies) for yearling release

Monitor and evaluate using guidelines developed in Chapter C of the Integrated System Plan

Selway River (Upper Meadow Creek) - Located in Clearwater River Basin near Kooskia, Idaho

Acquire broodstock from Clearwater River natural run

Alternative broodstock from Rapid River stock

Otilize Clearwater Anadromous Hatchery or Kooskia Hatchery for rearing to fed fry size

Release directly to stream for long term rearing

Monitor and evaluate using guidelines developed in Chapter $C$ of the Integrated system Plan 
Selway River (MCGruder Corridor) - Located in upper Selway River Acquire broodstock from Clearwater River natural run Alterntive broodstock from Rapid River stock

Utilize Clearwater Anadromous Hatchery or Kooskia Hatchery for rearing to fed fry size

Release directly to stream for long term rearing

Monitos and evaluate using guidelines developed in Chapter C of the Integrated system Plan

Grande Ronde River (Catherise Creek) - Located in Snake River system near LaGrande, Oregon

Acquire broodstock from Catherine Creek natural rus

Aternative broodstock from Rapid River stock

Utilize Lookingglass Hatchery for rearing to yearling size

Utilize acclimation facility(ies) for release

Monitor and evaluate using guidelines developed in Chapter C of the Integrated System Plan

Grande Ronde River (Upper Mainstem Grande Ronde R.) - Located in Srake River system rear LaGrande, Oregon

Acquire broodstock from Grande Ronde natural run

Aternative broodstock from Rapid River population

Utilize Lookingglass Hatchery for rearing to yearling size

otilize acclimation facility(ies) for release

Monitor and evaluate using guidelines developed in Chapter C of the Integrated System Plan 
Selway River (Fenn Pond) - Located in Clearwater River Basin near
Kooskia, Idabo

Acquire broodstock from Lower Granite Dam

Alternate broodstock from Lyons Ferry Hatchery

Utilize Lyons Ferry Hatchery for rearing subyearling size

Utilize rearing/acclimation facility(ies) for 2-6 weeks prior to release

Monitor and evaluate using guidelines developed in Chapter C of the Integrated system Plan

\section{Cobo Salmoa}

Yakima River (Wapato Canal Site) - Located in Yakima River Basin near Union Gap, Washingtor

Acquire broodstock from early run coho

Utilize Cascade Hatchery for rearing to yearling size

Utilize floating raceways or pens for acclimation prior to release

Monitor and evaluate using guidelines developed in Chapter $C$ of the Integrated System Plan

Yakima River (Roza Pasteway) - Located in the Yakima River basin near Wapato, Nashington

Acquire broodstock from early rus coho

Utilize Cascade Hatchery for rearing to yearling size

otilize barrier nets within the canal for acclimation prior to release

Monitor and evaluate using guidelines developed in Chapter C of the Integrated system Plan 
Selway River (Meadow Creek) - Located in the Clearwater River Basin near Kooskia, Idabo

Acquire broodstock from Salmon River natural run (e.g. South Fork or Middle Fork)

Utilize Clearwater Anadromous Hatchery or Kooskia Hatchery for rearing to yearling size

Utilize rearing/acclimation facility(ies) for 2-6 weeks prior to release

Monitor and evaluate using guidelines developed in Chapter $C$ of the Integrated System Plan

\section{Fal1 Chinook salmon}

Clearwater River (North Lapwai Valley) - Located in Snake River Basin near Lapwai, Idaho

Acquire broodstock from Lower Granite Dam

Alternative broodstock from Lyons Ferry Hatchery stock

Utilize Iyons Ferry Hatchery for rearing subyearling size

Utilize rearing/acclimation facility(ies) for 2-12 weeks prior to release

Monitor and evaluate using guidelines developed in Chapter $C$ of the Integrated system Plan 


\title{
Technical Appendix: \\ Analysis of Snake River Spring and Summer Chinook Rebuilding Schedules and Biological Objectives
}

\author{
Willis E. McConnaha and Duane A. Anderson \\ May 28, 1992
}

The following describes analysis prepared to assist the Council in its deliberations on rebuilding schedules and biological objectives for Snake River spring and summer chinook. The rebuilding schedules provide projections of the effectiveness of various actions on the number of fish that will return above Lower Granite Dam. They also provide a reference point against which to measure success based on existing information. Like projections of any kind, they are subject to the limitations in our knowledge and the effect of unforeseen events. Because of this, it would be a mistake to regard the numbers in the rebuilding schedules that are eventually incorporated into the fish and wildlife program as fixed standards against which to define or limit obligation. Rebuilding schedules should be viewed in much the same way as projections of investment returns in a prospectus -- as guidelines for investment but not guarantees of return. As information improves, and events unfold, new projections will be made.

The numbers provided in the draft amendments and discussed here should be regarded as preliminary and likely to change. The Council seeks comment on the numbers and hopes to stimulate discussion and examination of key assumptions. Technical staffs from the fishery agencies, tribes, Bonneville, and the utilities are working with the Council to review and coordinate use and development of models and other analytical tools. The Council invites constructive participation in this effort to coordinate development of rebuilding schedules, biological objectives and analytical methods.

\section{Purpose of the analysis.}

Phase II of the Council's amendment process called for the development of rebuilding schedules and biological objectives for identified population management units. These provide targets and time frames for rebuilding as well as the changes in survival at all life stages needed to achieve the schedules.

This analysis provides an initial examination of how three sets of plausible options might affect the rebuilding of Snake River spring and summer chinook salmon. Actions were chosen that fell within the range of measures identified by the Council in amendment phases 1-3. These actions were projected to result in certain changes in survival. The projected rebuilding results in options for rebuilding schedules while the survival changes become biological objectives. 


\section{Description of the Analysis.}

This analysis utilized several computer models to analyze different aspects of fish production and integrate these into a life cycle perspective. Descriptions and documentation for the model are available from the Council. The System Analysis Model was used to analyze the effect of different hydrosystem operations on flow during the spring out migration period in the Snake and Columbia rivers. These flows were analyzed for their effect on downstream fish survival with the Passage Analysis Model. In addition to flow options, the Passage Analysis Model was used to estimate the effect of predator reduction, screen installation, and transportation assumptions on fish survival. The resulting cumulative biological change of these and other variables was analyzed using the System Planning Model. This is a life cycle model that tracks fish from initial egg deposition to return as spawning adults over many generations. This resulted in a projected change in the number of fish at Lower Granite Dam as a result of taking a certain sequence of actions.

This analysis focused solely on the effect of the options on naturally spawning fish. No hatchery fish were included nor was supplementation considered. Supplementation would augment the numbers provided here to the extent that the technique was utilized and benefit was assumed.

Three sets of options for different actions were considered. The first assumes that draw down of all four Snake River pools to spillway would occur approximately on the schedule provided in phase 2 . Smolt transportation at Lower Granite and Little Goose was terminated with draw down. After draw down, no flow augmentation was used and the existing water budget was assumed to be used to refill reservoirs. The second option is termed a phased draw down. More time was provided to resolve uncertainties associated with draw down such as transportation, flow effectiveness and predator control. It was assumed that Lower Granite would be modified by 1996 to allow collection and transport of smolts at low pool elevations and Lower Granite Pool was lowered to spillway. In addition, $1 \mathrm{MAF}$ of water from the upper Snake drainage was used to augment flows. By the year 2000, the necessary certainty regarding draw down effectiveness was assumed to be available and the four Snake River pools were draw down to spillway. The third option assumed no draw down below minimum operating pool. Flow was augmented with an additional $1 \mathrm{MAF}$.

In all three options, habitat in Idaho was improved over time. A $25 \%$ improvement in egg-smolt survival was assumed to occur after being phased in over 12 years. This habitat improvement also was assumed to increase survival of adults prior to spawning by $5 \%$ after 12 years. Adult passage survival was improved by $5 \%$ in all three options presumably as a result of increased compliance with passage criteria and increased enforcement. All federal projects were assumed to be screened in accord with the schedule in phase 2 . Fish guiding efficiencies and other passage parameters were obtained from Bonneville's 
documentation for the Columbia River Salmon Passage Model (CRISP.0) ${ }^{1}$. Reservoir mortality rate was decreased in all three options presumably as a result of predator removal. For purposes of this analysis, the maximum reduction was assumed to be $25 \%$ phased in over 12 years.

For each package of actions, the change in survival at the appropriate life stage had to be estimated. As noted above, the Passage Analysis Model was used to estimate the change in juvenile passage survival. Although the estimation of juvenile passage survival can be a controversial exercise, the effect of actions on survival at other life stages is even less precisely know. For life stages other than mainstem passage, judgments were made as to the effect of actions on survival. The intent was not to suggest an exact estimate of effect but to arrive at a plausible estimate that can serve until more information is available. In some cases, it may be necessary to use ranges or analyze the effect of valid alternative estimates.

In addition to estimating the effect of actions on survival, a time frame for implementation of actions had to be determined. All actions will not happen immediately or simultaneously. In addition, implementation of some actions, such as draw down of Snake River pools to enhance water velocity, depends on further consideration and new information. Even as the biological effect of some actions is not clear, the time schedule within which events will occur is also unknown. The actual schedule will be determined by funding, manpower, and regional policy decisions. For this exercise, an implementation schedule was used that reflects dates specified in the Council's program for some actions and judgments as to when other actions might occur.

Descriptions of the three options are provided below.

1 Fisher, T., and B.M. Sherer, 1992. Input parameters for the modeling of Snake River salmon with the Columbia River Salmon Passage Model (CRISP.0). Bonneville Power Administration, January 8, 1992. 


\section{Option 1: Four pool draw down}

\begin{tabular}{|c|c|c|c|c|}
\hline & Cycle 1 & Cycle 2 & Cycle 3 & Cycle 4 \\
\hline & 1992-1995 & 1996-1999 & $2000-2003$ & 2004-2007 \\
\hline Flow & Phase 2 & $\begin{array}{l}\text { No Snake River } \\
\text { water budget }^{2}\end{array}$ & $\begin{array}{c}\text { No Snake River } \\
\text { water budget }\end{array}$ & $\begin{array}{c}\text { No Snake } \\
\text { River water } \\
\text { budget }\end{array}$ \\
\hline Draw down & $\begin{array}{c}\text { Minimum } \\
\text { irrigation pools }\end{array}$ & $\begin{array}{l}\text { Four Snake } \\
\text { River projects to } \\
\text { spillway, John } \\
\text { Day pools to } \\
\text { minimum } \\
\text { operating level }\end{array}$ & $\begin{array}{l}\text { Four Snake River } \\
\text { projects to } \\
\text { spillway, John } \\
\text { Day to minimum } \\
\text { operating level }\end{array}$ & $\begin{array}{c}\text { Four Snake } \\
\text { River projects } \\
\text { to spillway, } \\
\text { John Day to } \\
\text { minimum } \\
\text { operating level }\end{array}$ \\
\hline $\begin{array}{l}\text { Reduction in } \\
\text { reservoir } \\
\text { mortality due } \\
\text { to predator } \\
\text { reduction }\end{array}$ & $6.25 \%$ & $12.5 \%$ & $25.0 \%$ & Same \\
\hline Screens & $\begin{array}{c}\text { Monumental } \\
\text { screened }\end{array}$ & Full & Full & Full \\
\hline Adult Passage & $\begin{array}{l}90 \% \text { survival at } \\
\text { Bonneville- } \\
\text { McNary, } 95 \% \\
\text { Ice Harbor to } \\
\text { Lower Granite }\end{array}$ & $\begin{array}{c}5 \% \text { increase in } \\
\text { survival at all } \\
\text { projects }\end{array}$ & Same & Same \\
\hline $\begin{array}{c}\text { Juvenile } \\
\text { survival rate as } \\
\text { a result of } \\
\text { habitat quality } \\
\text { and quantity }\end{array}$ & $10 \%$ & $10 \%$ & $11.25 \%$ & $12.5 \%$ \\
\hline $\begin{array}{l}\text { Pre-spawning } \\
\text { survival as a } \\
\text { result of habitat } \\
\text { quality }\end{array}$ & $80 \%$ & $80 \%$ & $80 \%$ & $85 \%$ \\
\hline
\end{tabular}

2 Under a four pool draw down, no flow augmentation was needed to reach $140 \mathrm{kcfs}$ equivalent in the Snake. It was assumed that the water budget would be used to refill reservoirs after draw down. 


\section{Option 2: Phased draw down}

\begin{tabular}{|c|c|c|c|c|}
\hline & Cycle 1 & Cycle 2 & Cycle 3 & Cycle 4 \\
\hline & 1992-1995 & 1996-1999 & $2000-2003$ & 2004-2007 \\
\hline Flow & Phase 2 & $\begin{array}{c}\text { Additional } 1 \\
\text { MAF in Snake } \\
\text { River }\end{array}$ & $\begin{array}{l}\text { No Snake River } \\
\text { water budget }\end{array}$ & $\begin{array}{c}\text { No Snake River } \\
\text { water budget }\end{array}$ \\
\hline Draw down & $\begin{array}{c}\text { Minimum } \\
\text { irrigation pools }\end{array}$ & $\begin{array}{l}\text { Lower Granite to } \\
\text { spillway with } \\
\text { smolt } \\
\text { transportation. } \\
\text { Other Snake } \\
\text { River and John } \\
\text { Day pools to } \\
\text { minimum } \\
\text { operating level. }\end{array}$ & $\begin{array}{l}\text { Four Snake River } \\
\text { projects to } \\
\text { spillway. John } \\
\text { Day to minimum } \\
\text { operating level }\end{array}$ & $\begin{array}{l}\text { Four Snake } \\
\text { River projects } \\
\text { to spillway. } \\
\text { John Day to } \\
\text { minimum } \\
\text { operating level }\end{array}$ \\
\hline $\begin{array}{l}\text { Reduction in } \\
\text { reservoir } \\
\text { mortality due } \\
\text { to predator } \\
\text { reduction }\end{array}$ & $6.25 \%$ & $12.5 \%$ & $25.0 \%$ & Same \\
\hline Screens & $\begin{array}{c}\text { Monumental } \\
\text { screened }\end{array}$ & Full & Full & Full \\
\hline Adult Passage & $\begin{array}{l}90 \% \text { survival at } \\
\text { Bonneville- } \\
\text { McNary, } 95 \% \\
\text { Ice Harbor to } \\
\text { Lower Granite }\end{array}$ & $\begin{array}{c}5 \% \text { increase in } \\
\text { survival at all } \\
\text { projects }\end{array}$ & Same & Same \\
\hline $\begin{array}{c}\text { Juvenile } \\
\text { survival rate as } \\
\text { a result of } \\
\text { habitat quality } \\
\text { and quantity }\end{array}$ & $10 \%$ & $10 \%$ & $11.25 \%$ & $12.5 \%$ \\
\hline $\begin{array}{l}\text { Pre-spawning } \\
\text { survival as a } \\
\text { result of habitat } \\
\text { quality }\end{array}$ & $80 \%$ & $80 \%$ & $80 \%$ & $85 \%$ \\
\hline
\end{tabular}

3 The additional $1 \mathrm{MAF}$ in the second cycle is assumed to be used to augment summer flows after the four pool draw down occurs. 


\section{Option 3: Flow Augmentation.}

\begin{tabular}{|c|c|c|c|c|}
\hline & Cycle 1 & Cycle 2 & Cycle 3 & Cycle 4 \\
\hline & 1992-1995 & 1996-1999 & $2000-2003$ & 2004-2007 \\
\hline Flow & Phase 2 & $\begin{array}{c}\text { Additional } 1 \\
\text { MAF in Snake }\end{array}$ & $\begin{array}{l}\text { Additional 1 MAF } \\
\text { in Snake }\end{array}$ & $\begin{array}{c}\text { Additional } 1 \\
\text { MAF in Snake }\end{array}$ \\
\hline Draw down & $\begin{array}{l}\text { Snake and John } \\
\text { Day pools at } \\
\text { minimum } \\
\text { irrigation levels }\end{array}$ & $\begin{array}{l}\text { Snake and John } \\
\text { Day pools at } \\
\text { minimum } \\
\text { operating levels }\end{array}$ & Same & Same \\
\hline $\begin{array}{l}\text { Reduction in } \\
\text { reservoir } \\
\text { mortality due to } \\
\text { predator } \\
\text { reduction } \\
\end{array}$ & $6.25 \%$ & $12.5 \%$ & $25.0 \%$ & Same \\
\hline Screens & $\begin{array}{c}\text { Monumental } \\
\text { screened }\end{array}$ & Full & Full & Full \\
\hline Adult Passage & $\begin{array}{l}90 \% \text { survival at } \\
\text { Bonneville- } \\
\text { McNary, } 95 \% \text { Ice } \\
\text { Harbor to Lower } \\
\text { Granite }\end{array}$ & $\begin{array}{c}5 \% \text { increase in } \\
\text { survival at all } \\
\text { projects }\end{array}$ & Same & Same \\
\hline $\begin{array}{c}\text { Juvenile } \\
\text { survival rate as } \\
\text { a result of } \\
\text { habitat quality } \\
\text { and quantity }\end{array}$ & $10 \%$ & $10 \%$ & $11.25 \%$ & $12.5 \%$ \\
\hline $\begin{array}{l}\text { Pre-spawning } \\
\text { survival as a } \\
\text { result of habitat } \\
\text { quality }\end{array}$ & $80 \%$ & $80 \%$ & $80 \%$ & $85 \%$ \\
\hline
\end{tabular}

Smolt Transportation Assumption. Rebuilding of Snake River spring and summer chinook under the three options described above was examined using two alternative models for smolt transportation. This is particularly important in regard to the evaluation of pool draw down as a means to increase water velocities and improve survival. It was assumed here that smolt transportation at Lower Granite and Little Goose would not take place under the option of drawing all four Snake River projects down to spillway, although it would occur in the baseline and other options. Thus how draw down is projected to affect survival relative to other options depends to a large degree on the assumption made about the benefits of transportation.

Like most factors affecting the survival of downstream migrating salmon and steelhead, the benefits of transportation are uncertain and controversial. While much work was done during the 1970's to evaluate and develop transportation techniques, stock composition, facilities, and transportation techniques have 
changed considerably in the last decade. There is really only one study that has examined the effects of transportation under modern conditions ${ }^{4}$. This study occurred in 1986 and estimated that the ratio of adult production between transported and non-transported fish (termed the transport benefit ratio or TBR) was 1.6:1 from Little Goose Dam (transported fish survived to adulthood $60 \%$ better than non-transported fish under 1986 conditions). Concerns for the effect of marking and releasing a control group to migrate during unfavorable flow conditions has prevented further evaluation. As a result, estimating the effects of transportation under conditions different from the 1986 study requires speculation.

Two alternative models of transportation were examined in this study (Figure 1). Briefly, Model 1 assumes a relatively high benefit of transportation under low flow conditions, while Model 2 assumes a more modest benefit at low flows. In both, benefits decline as survival of non-transported fish increases.

Under Model 1, the survival of transported fish once they are in the transport vehicle is constant between years and between projects regardless of conditions outside the vehicle (survival of transported fish up to the point of collection is affected by outside conditions). Because the survival of non-transported fish changes as a result of flow conditions, predator control, and other measures, the benefits of transportation change and decrease as the survival of non-transported fish increases. Under the lowest flow, this model estimates transport benefit ratios at Lower Granite Dam for spring chinook in excess of 15:1. For this model, the survival of transported fish was estimated based on the 1986 observation. This figure was then used for all subsequent analysis.

Model 2 is a modification of the first model. Conditions prior to collection could affect the survival of fish in the vehicle. Under low flows, for example, fish could arrive at the collection point in poor condition and have lower survival in the vehicle than they would under better flow conditions. Unfortunately, we only have the one direct observation in 1986. To examine this model, it was assumed that the transport benefit under the lowest flow condition (1977) was 3:1 at Little Goose Dam. The observation of benefits of 1.6:1 in 1986 was also used. For flows above the 1986 level, survival of transported fish was assumed to be equal to the estimated 1986 level. Transport survival was interpolated for conditions between 1986 and the lowest flow (Figure 1).

4 Matthews, G.M., S. Achord, J.R. Harmon, O.W. Johnson, D.M Marsh, B.P. Stanford, N.N. Paasch, K.W. McIntyre, and K.L. Thomas, 1991. Evaluation of transportation of juvenile salmonids and related research on the Columbia and Snake Rivers, 1990. US Army Corps of Engineers Research Report, Seattle, WA. 


\section{Figure 1: Alternative Smolt Transportation Models}

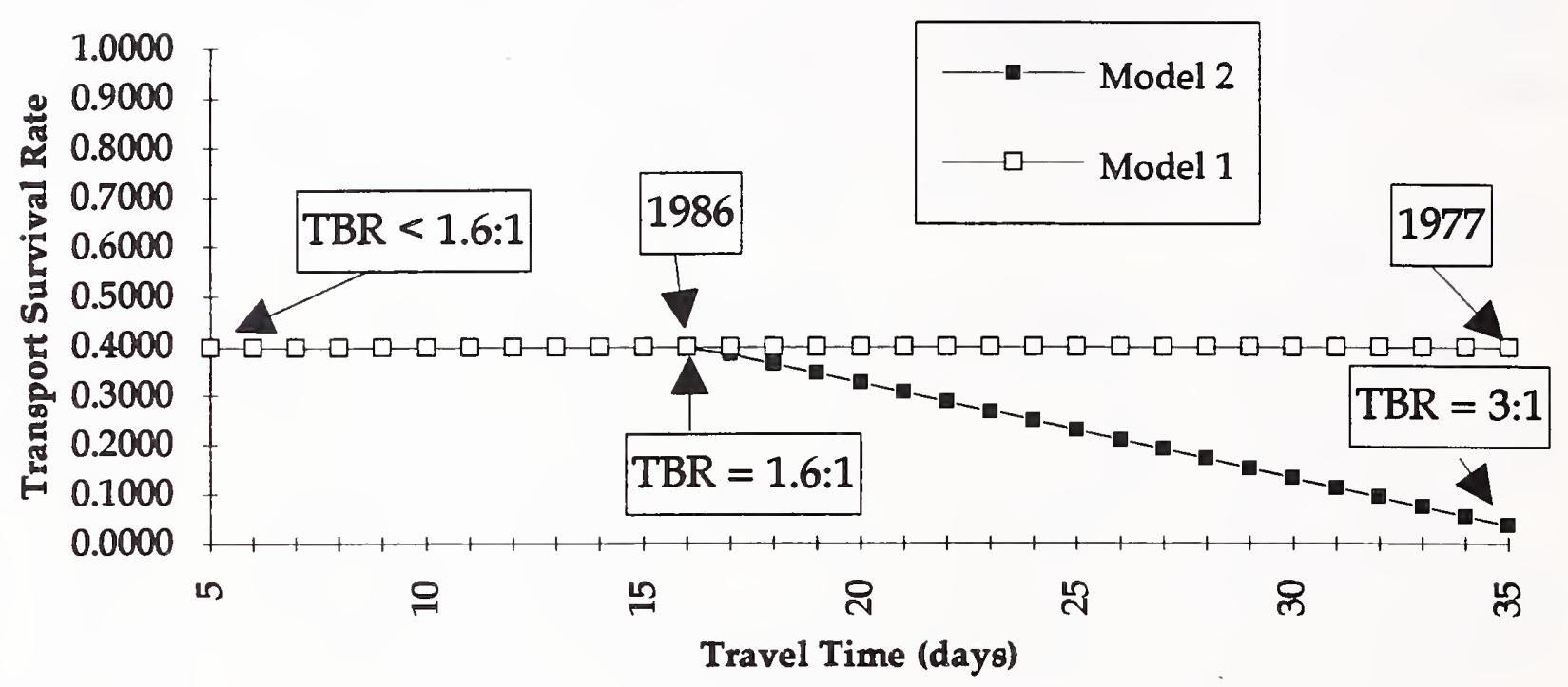

\section{Results.}

The biological effect of the three options for the two species under two transportation models was characterized by the change in the number of naturally spawning adult fish estimated to cross Lower Granite Dam. The analysis was summarized by plotting the median return. For each graph, the analysis was repeated 500 times each time varying the flow and random variation. The range in results is shown by the $10 \%$ and $90 \%$ points which indicate that $80 \%$ of the time the results fell within this range.

The ultimate effect of the three options was surprisingly similar. For spring chinook under transportation model 1 , all three resulted in about 25-30,000 naturally spawning fish over Lower Granite Dam by about the year 2023 (Figures 2 -4). Draw down (Options 1 and 2 ) produced the most fish $(-30,000)$ compared to about 25,000 fish with flow augmentation and smolt transportation (Option 3). These same actions resulted in about 10-12,000 summer chinook by the same time (Figures 5-7). Transportation model 2 resulted in more fish than model $1^{5}$ although the three options still produced similar numbers. Under model 2 transportation all three options produced about 35-40,000 spring chinook by 2023 (Figures 8-10) and about 13-15,000 summer chinook (Figures 11-13).

As expected, the two transportation models influenced the projected effectiveness of draw down. Under transportation model 1, during low flow years

5 The reason for this was that under model 2, the effect of flow, predator control or other actions to improve the survival of non-transported fish had a greater effect since transport was assumed to be less effective. Because both models started from the same number of fish, the greater percentage effect of the action under model 2 resulted in more fish. 
draw down actually decreased survival relative to the base condition by eliminating transportation at Lower Granite and Little Goose dams (Table 1). Many of the fish that survived relatively well through the Snake River during these years died in the poorer passage conditions in the Columbia River even though many were transported from McNary Dam. Because transportation under Model 1 had high benefits at low flow, the loss of transportation during these years decreased survival relative to the base case. Under Model 1, augmenting flows and retaining transportation had the highest survival increase in the lower flow years. In the higher flow years, the four pool draw down improved survival regardless of the transport assumption.

\begin{tabular}{|c|c|c|c|}
\hline & Table 1: C & $\begin{array}{l}\text { passag } \\
\text { condit } \\
\text { rtation }\end{array}$ & val rate from \\
\hline & & year 192 & \\
\hline & 8 Lowest & Next 12 & Average of 50 \\
\hline Phase $2^{6}$ & $8.3 \%$ & $4.3 \%$ & $3.5 \%$ \\
\hline $\begin{array}{l}1 \text { MAF } \\
\text { augmentation } 7\end{array}$ & $20.6 \%$ & $12.0 \%$ & $10.6 \%$ \\
\hline $\begin{array}{l}\text { Four pool draw } \\
\text { down } 8\end{array}$ & $-15.0 \%$ & $1.3 \%$ & $8.1 \%$ \\
\hline & & rtation & \\
\hline Phase 2 & $39.1 \%$ & $17.7 \%$ & $3.6 \%$ \\
\hline $\begin{array}{l}1 \text { MAF } \\
\text { augmentation }\end{array}$ & $88.4 \%$ & $35.2 \%$ & $10.3 \%$ \\
\hline $\begin{array}{l}\text { Four pool draw } \\
\text { down }\end{array}$ & $65.3 \%$ & $24.9 \%$ & $18.7 \%$ \\
\hline
\end{tabular}

The effectiveness of measures such as flow which primarily increase the survival of non-transported fish had a much greater affect on overall survival under transportation model 2 than under model 1 (Table 1). Under model 1, transported fish enjoy a relatively high survival which dampens the effect of other measures. In Model 2, the 1 MAF flow augmentation option with transportation still showed a higher survival than did the four pool drawdown in the lowest flow years. However, in all years draw down improved survival over the base condition. In most of the better flow years, draw down showed higher survival than flow augmentation.

\footnotetext{
6 Includes $6.25 \%$ reduction in reservoir mortality rate due to predator control.

${ }^{7}$ Includes $12.5 \%$ reduction in reservoir mortality rate due to predator control.

8 Includes $12.5 \%$ reduction in reservoir mortality rate due to predator control.
} 


\section{FIGURE 2}

\section{Snake River Natural Spring Chinook Option 1}

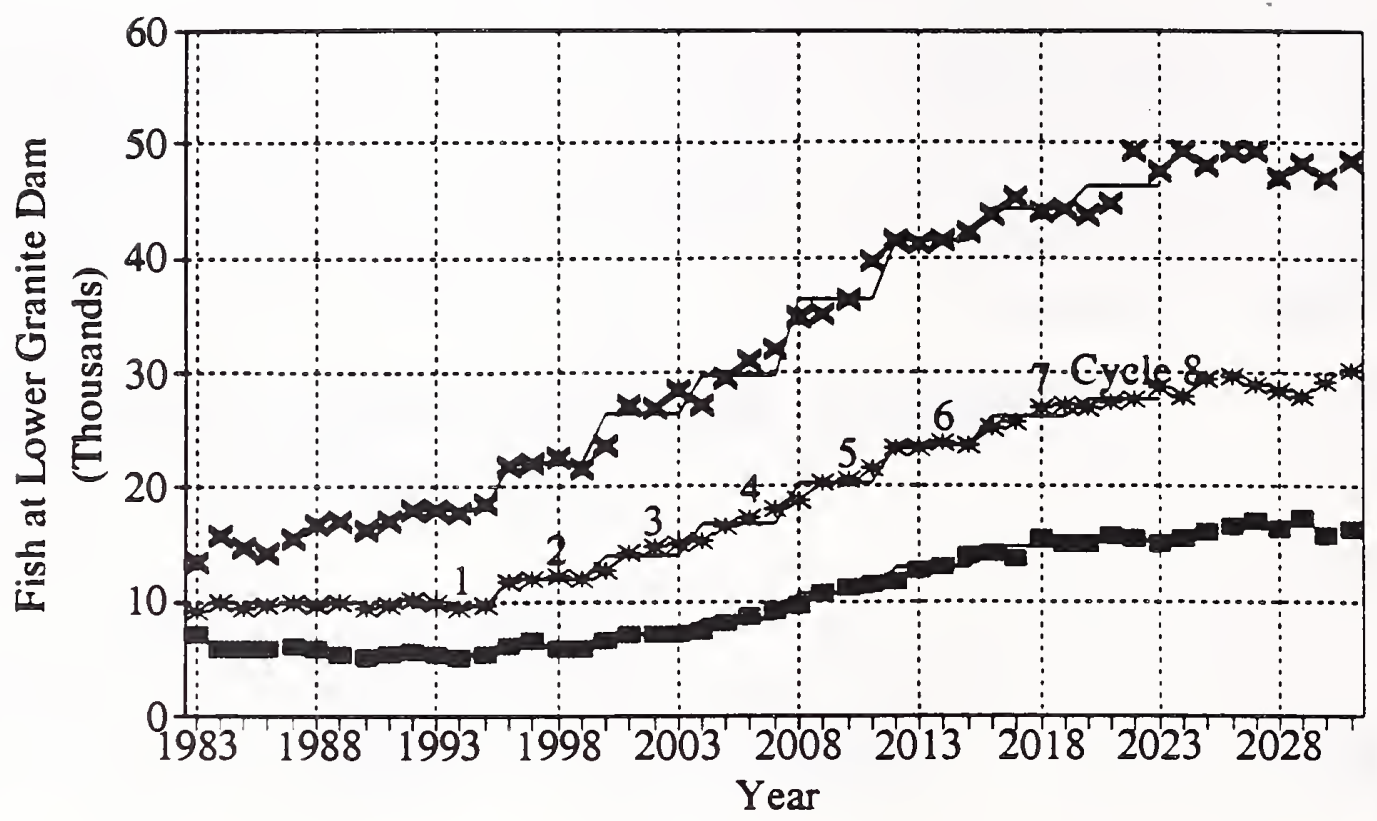

- $10 \%$ Median $\times 90 \%$

\section{FIGURE 3}

Snake River Natural Spring Chinook Option 2

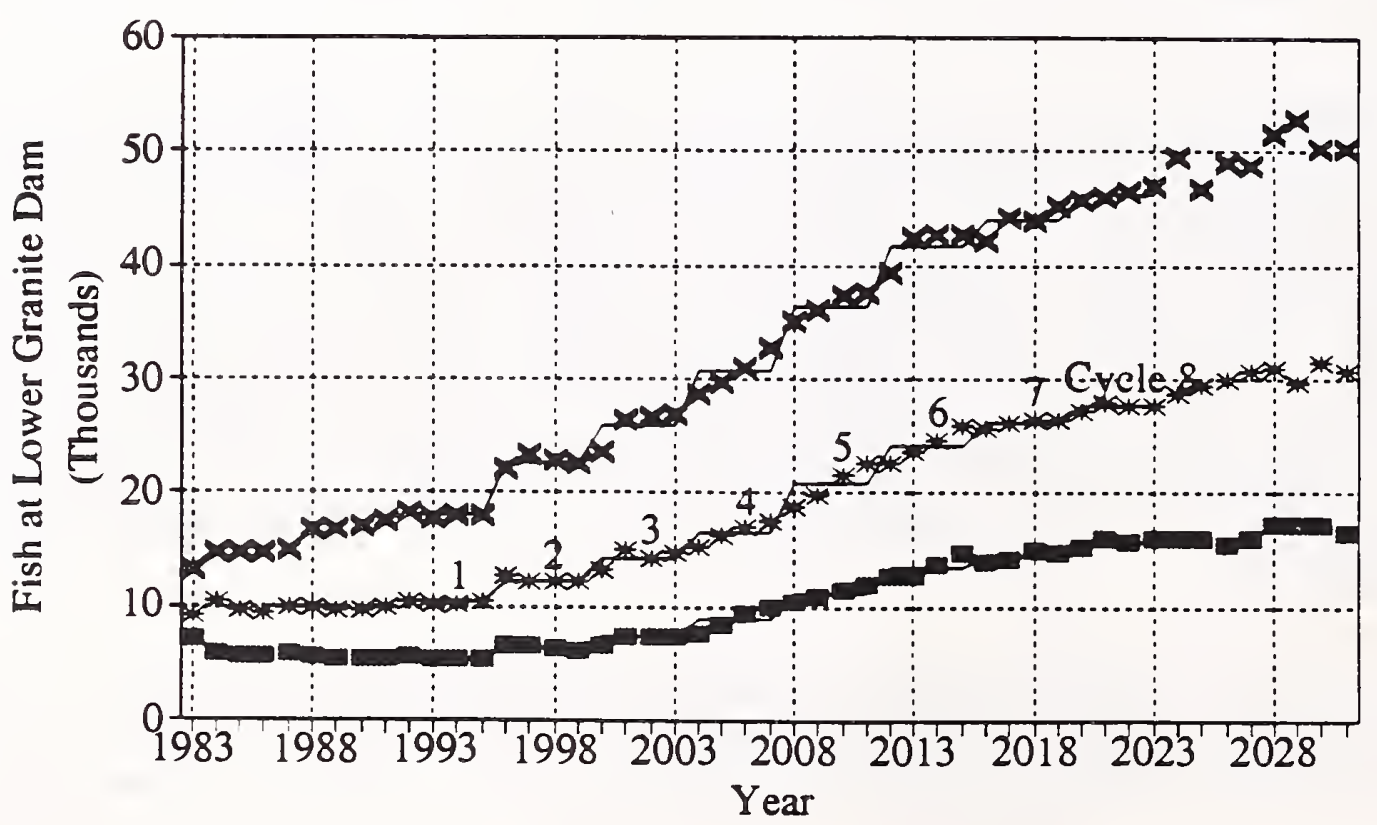

$=10 \%$ Median × $90 \%$




\section{FIGURE 4}

\section{Snake River Natural Spring Chinook Option 3}

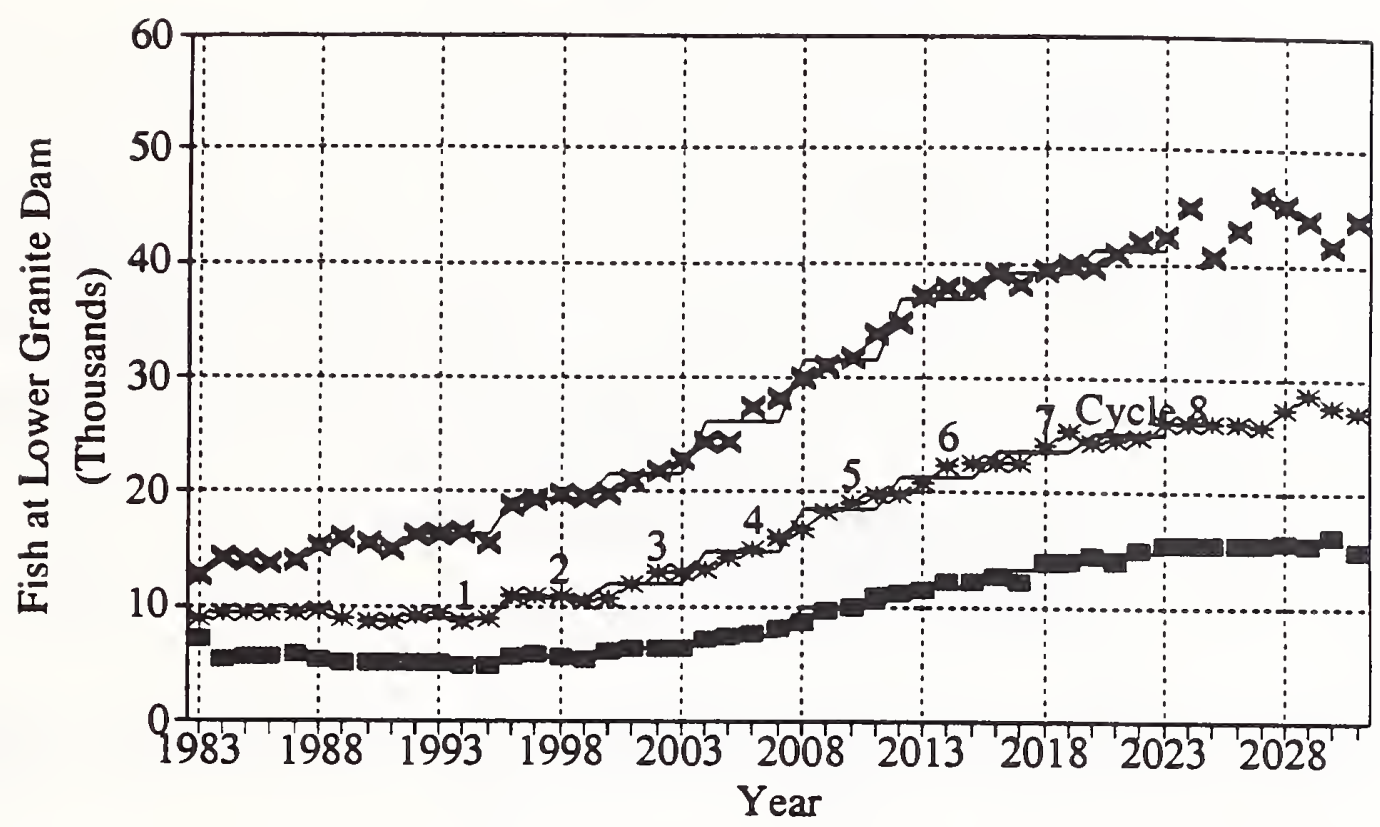

= $10 \%$ * Median $\times 90 \%$

\section{FIGURE 5}

\section{Snake River Natural Summer Chinook Option 1}

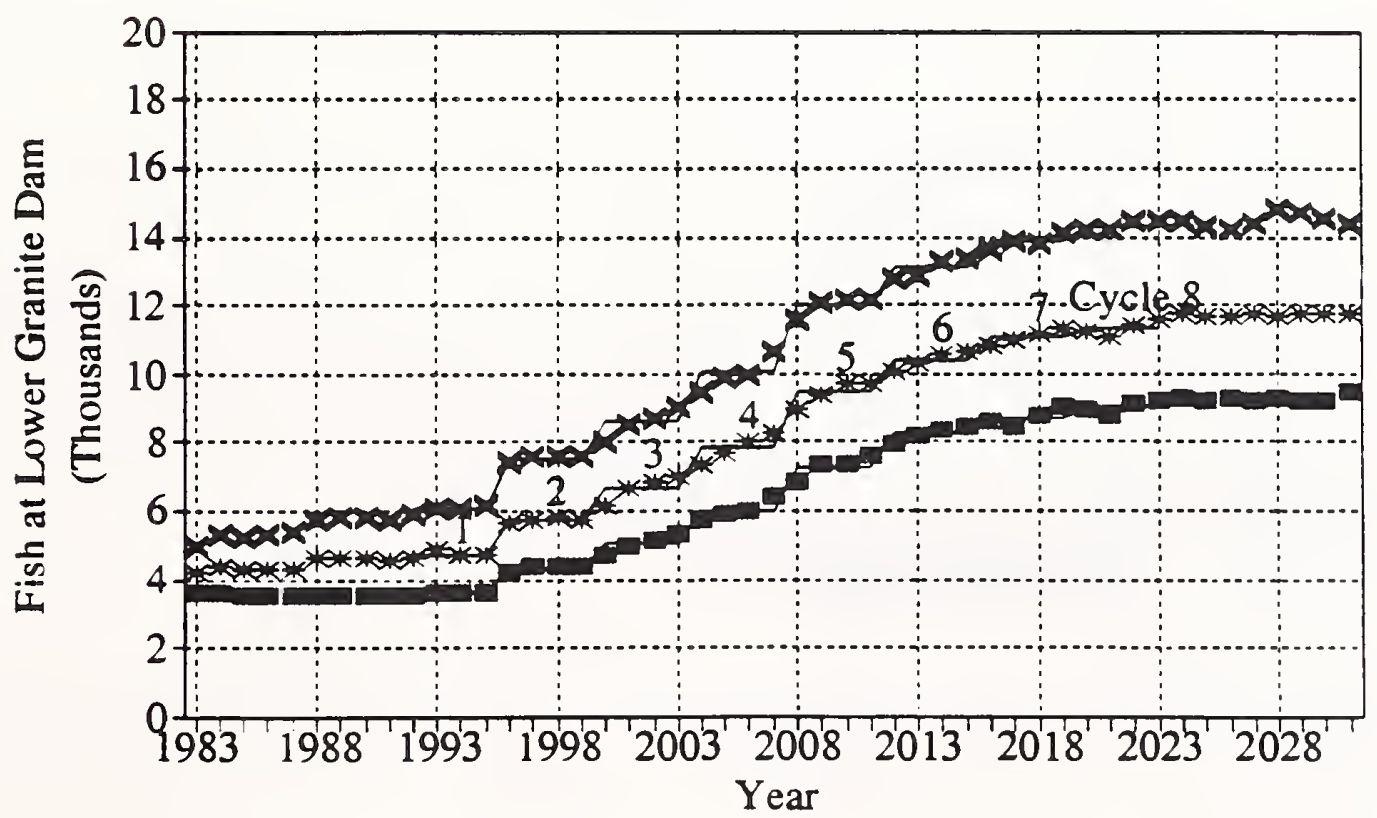

$\begin{array}{lll}-10 \% & * & \text { Median } \times 90 \%\end{array}$




\section{FIGURE 6}

\section{Snake River Natural Summer Chinook Option 2}

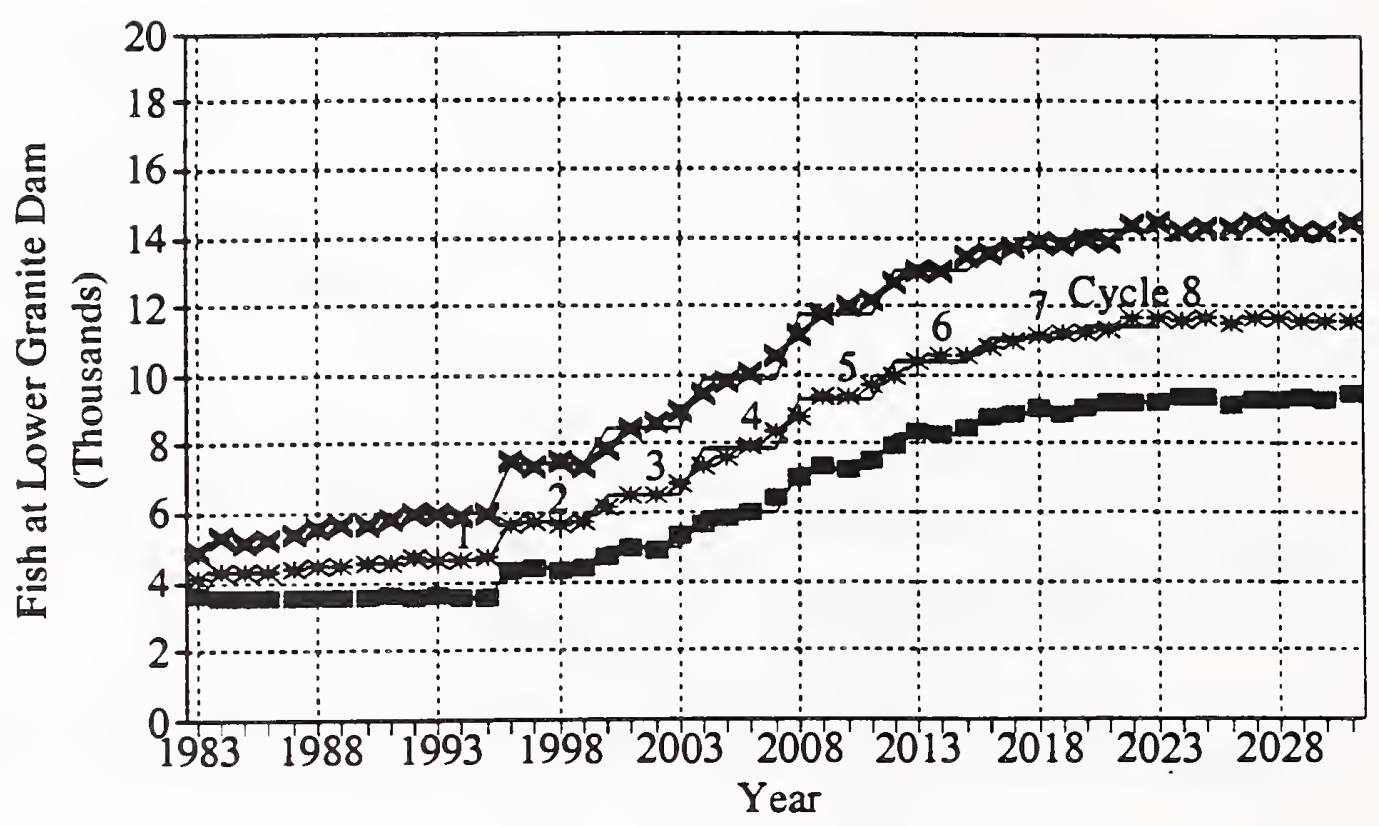

$=10 \%$ * Median × $90 \%$

\section{FIGURE 7}

\section{Snake River Natural Summer Chinook} Option 3

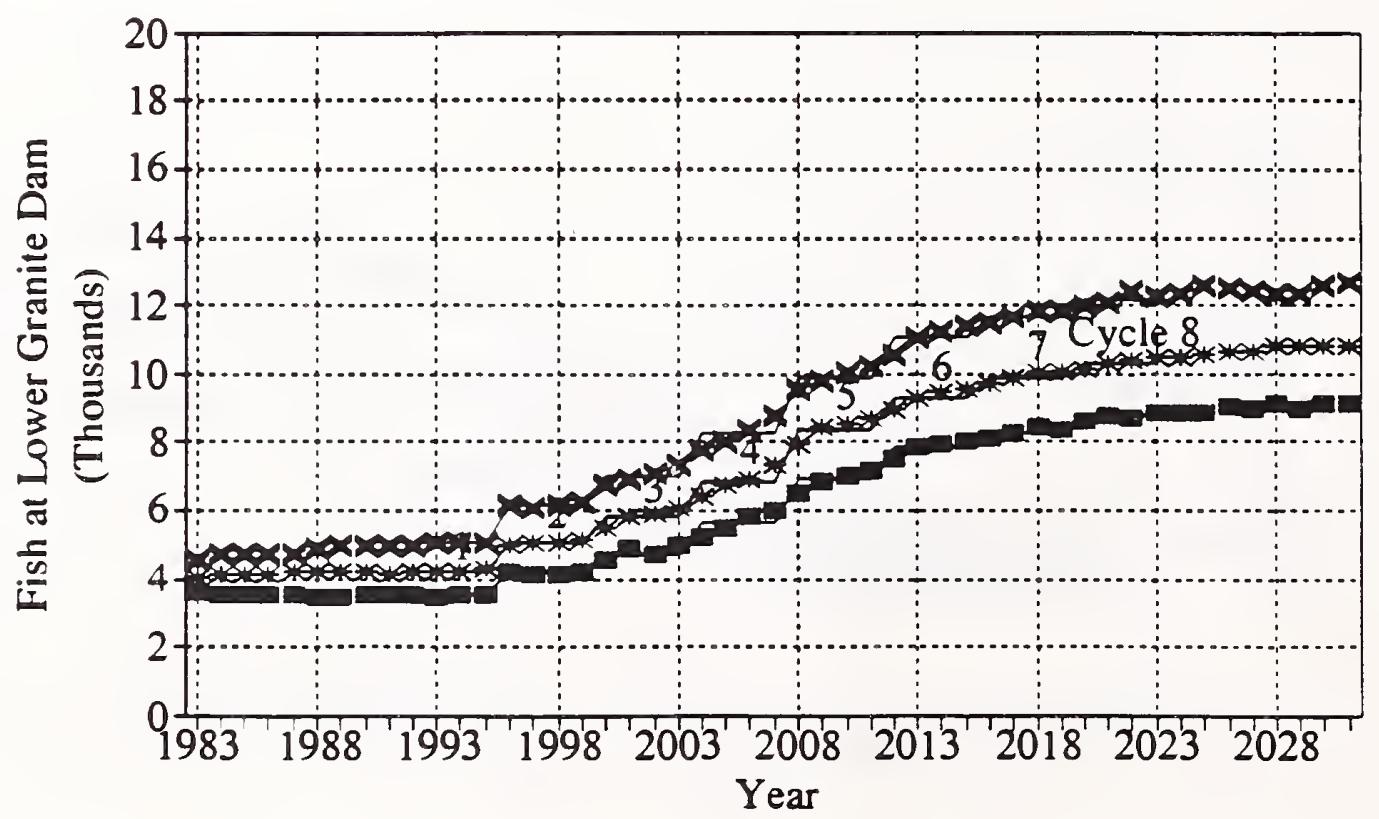

- $10 \%$ Median × $90 \%$ 


\section{FIGURE 8}

\section{Snake River Natural Spring Chinook Option 1; TBR Model 2}

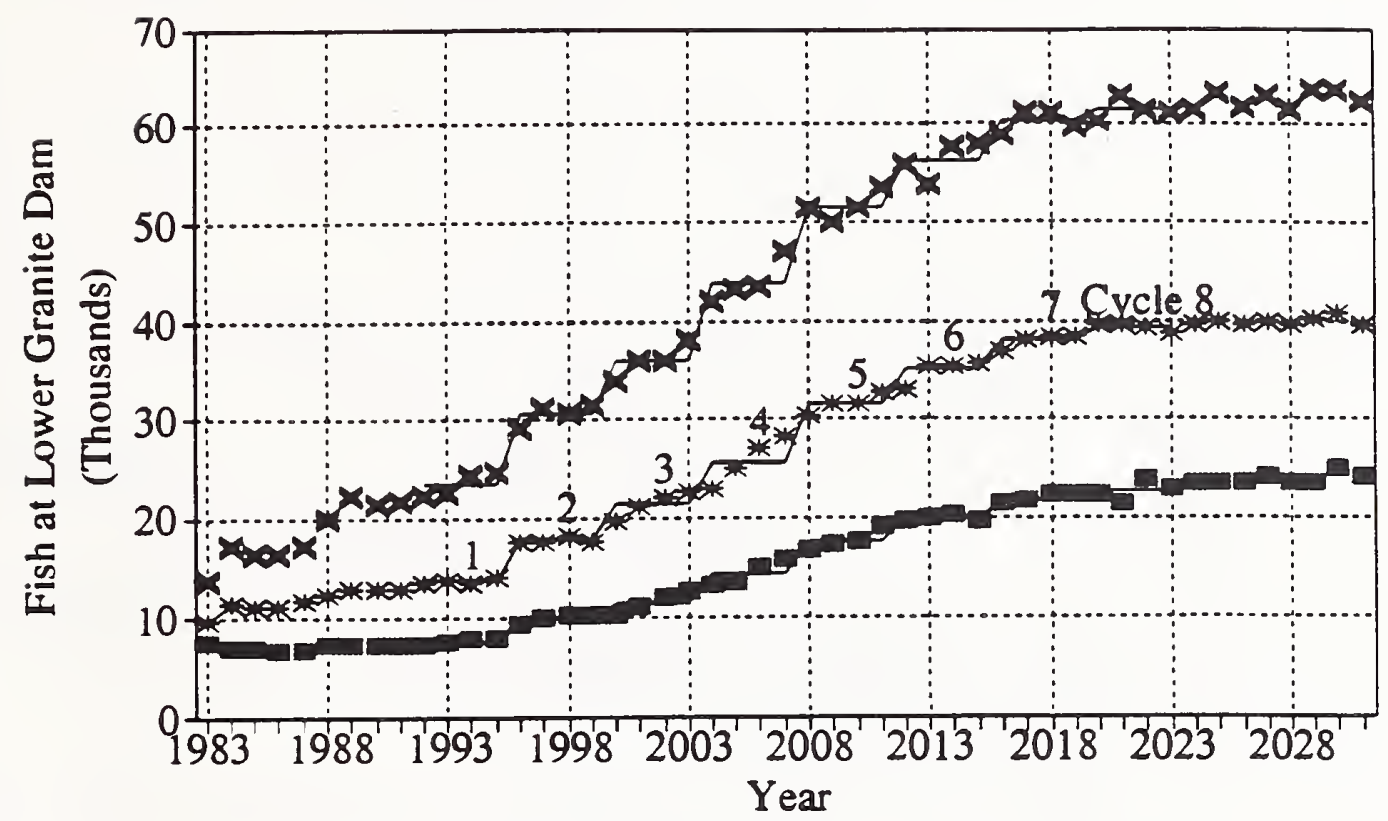

- $10 \%$ * Median $\times 90 \%$

\section{FIGURE 9}

\section{Snake River Natural Spring Chinook Option 2; TBR Model 2}

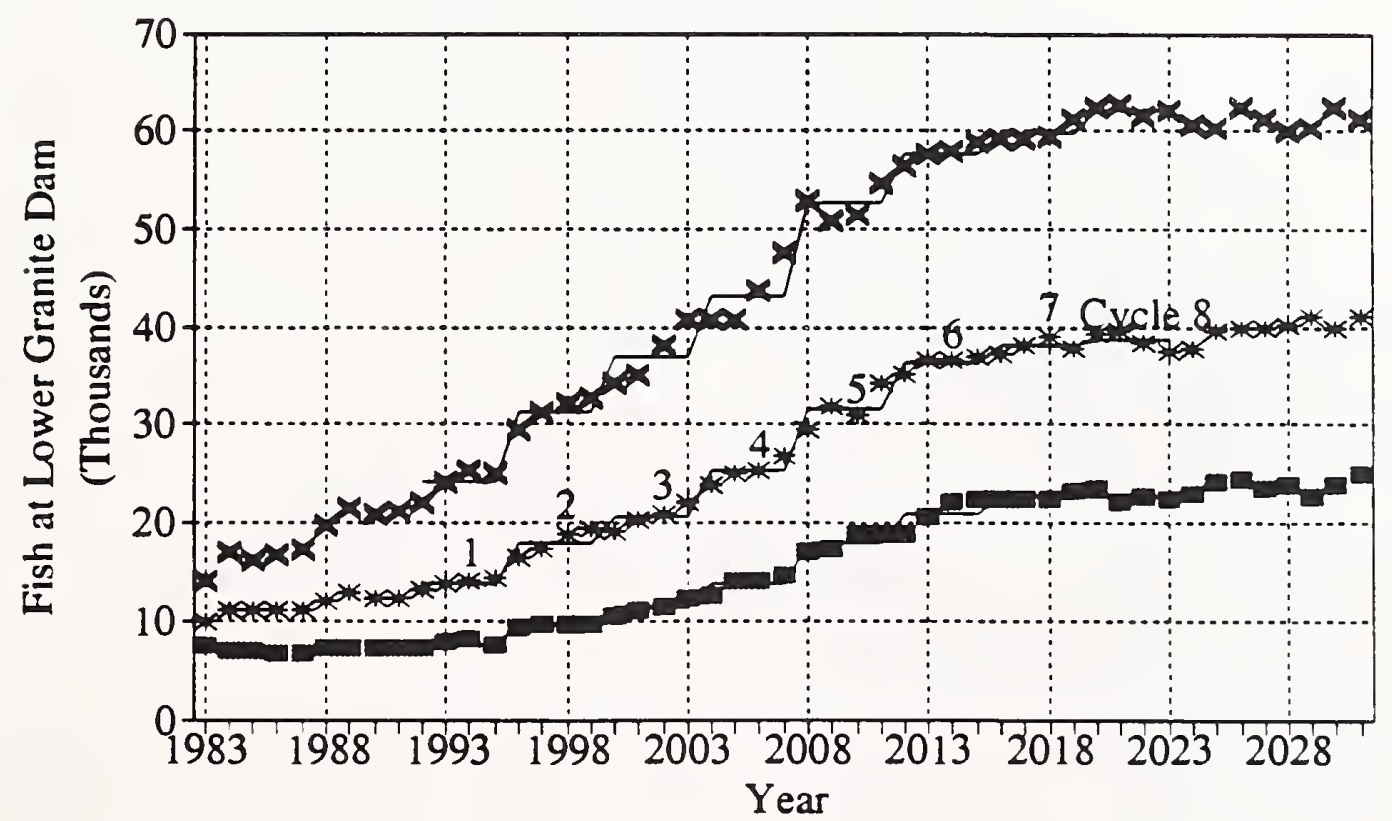

- $10 \%$ * Median $\times 90 \%$ 


\section{FIGURE 10}

\section{Snake River Natural Spring Chinook Option 3; TBR Model 2}

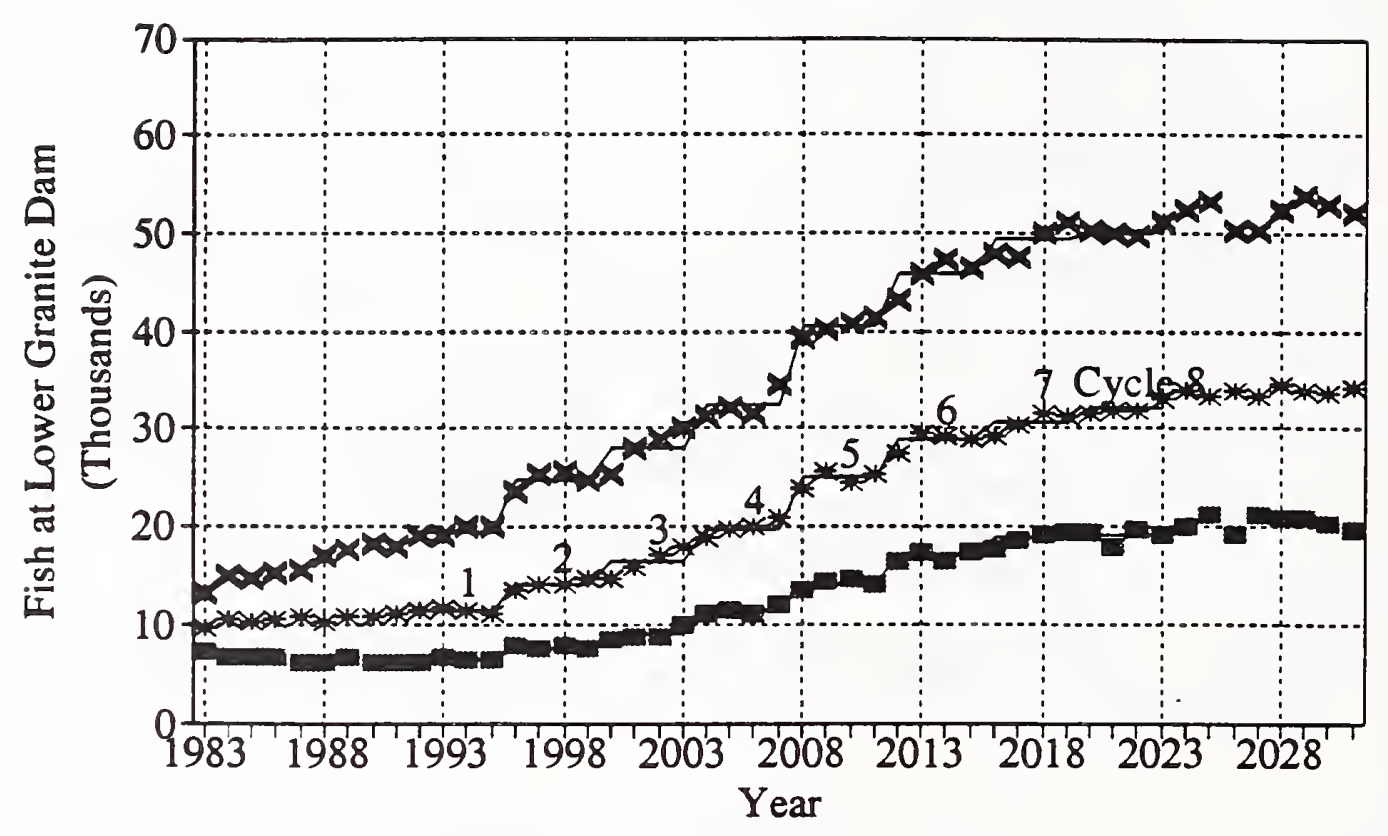

\begin{tabular}{|llll}
\hline$-10 \%$ & $*$ & Median $\times 90 \%$ \\
\hline
\end{tabular}

\section{FIGURE 11}

\section{Snake River Natural Summer Chinook Option 1; TBR Model 2}

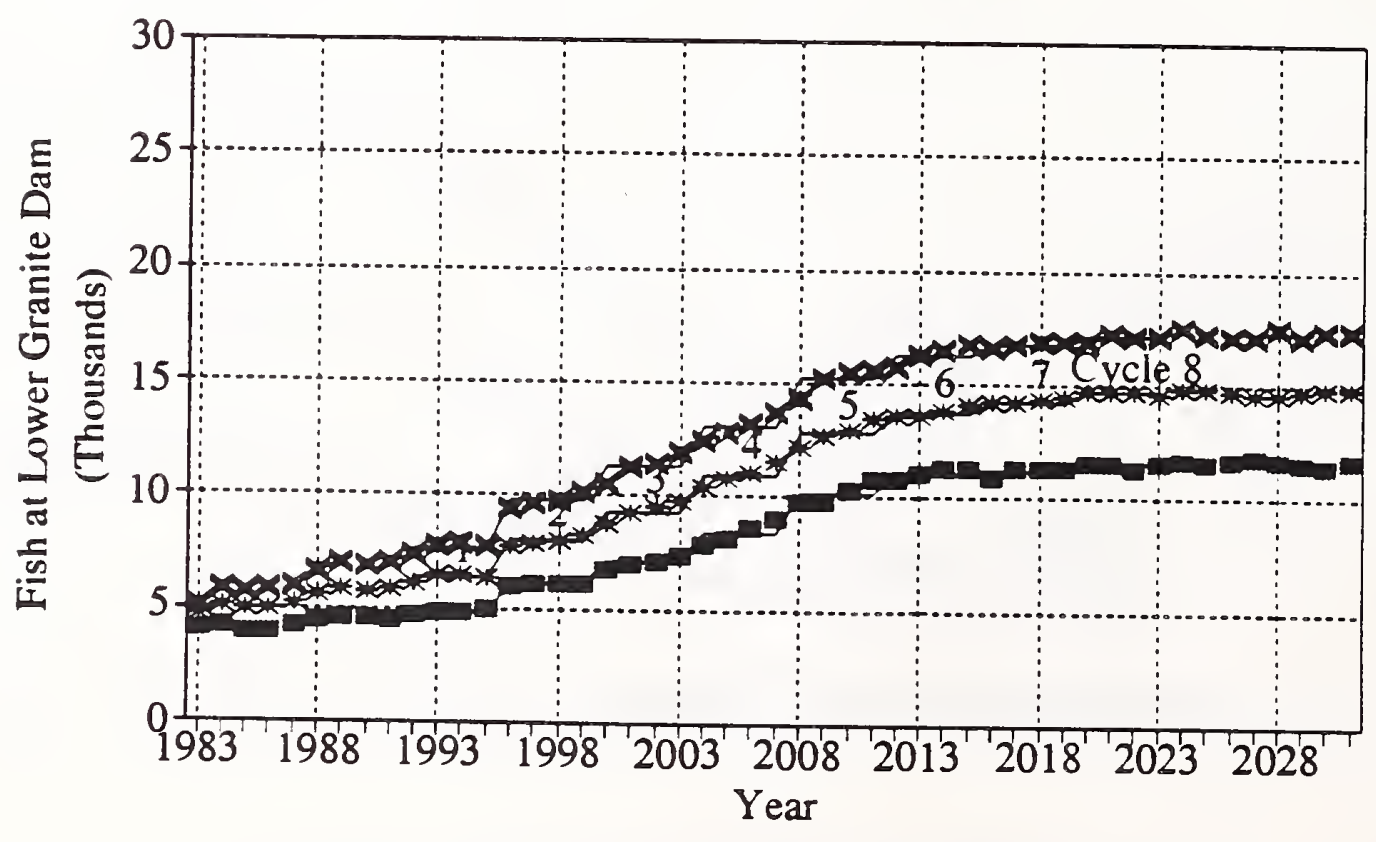

$=10 \% \quad *$ Median $\times 90 \%$




\section{FIGURE 12}

\section{Snake River Natural Summer Chinook}

Option 2; TBR Model 2

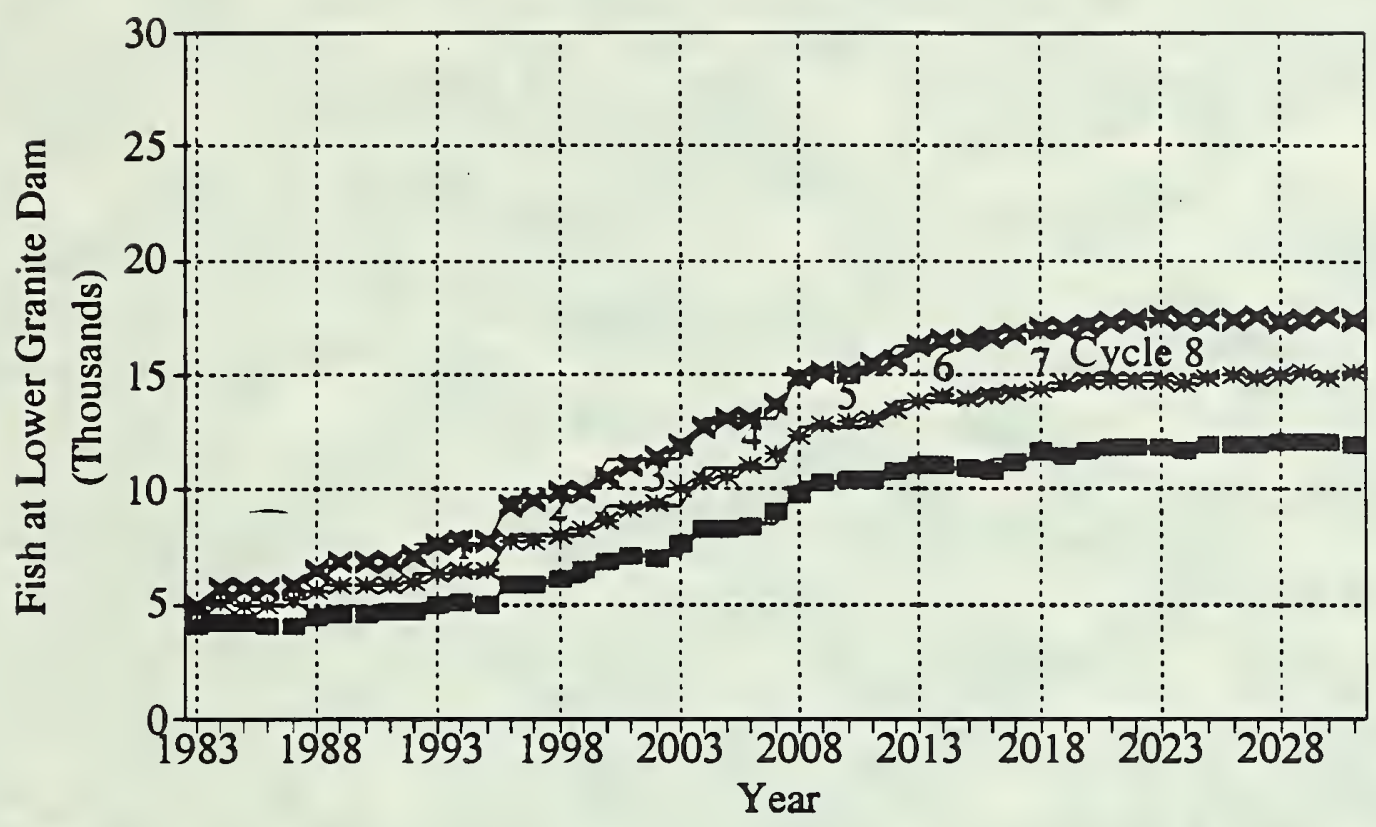

- $10 \%$ * Median $\times 90 \%$

FIGURE 13

Snake River Natural Summer Chinook Option 3; TBR Model 2

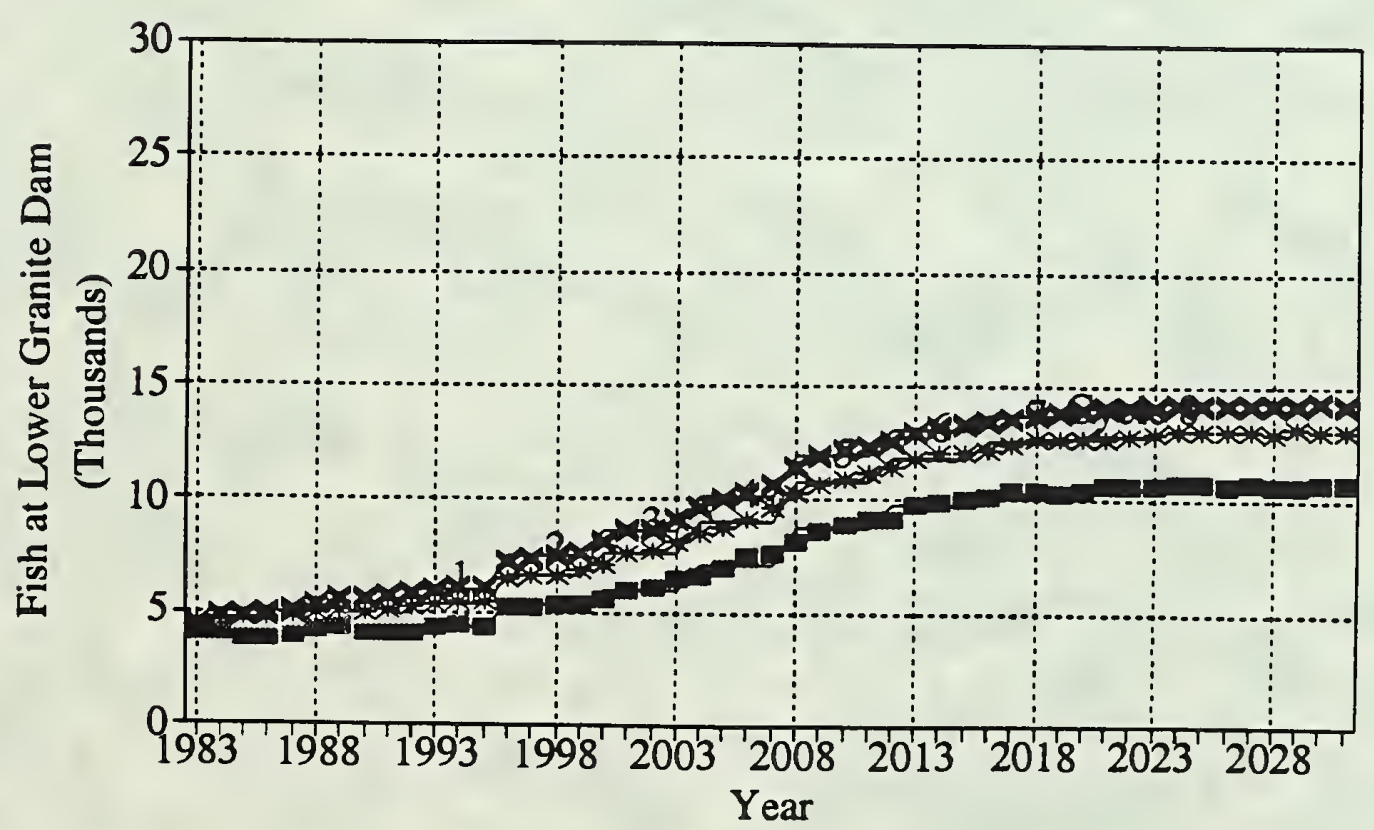

- $10 \%$ * Median $\times 90 \%$ 
